\title{
ELEMENTOS DISCURSIVOS
}

EL PROBLEMA DE LA IDEA de idea de proyecto de obra COMO “OBJETO DE SABER" EN RELACIÓN AL PROYECTO ARTÍSTICO

Tesis Doctoral presentada por Bárbaro Julian Miyares Puig Directora Dra. Salomé Cuesta Valera

Programa de Doctorado: Artes Visuales e Intermedia Departamento de Escultura - Facultad de Bellas Artes de Valencia Universitat Politècnica de València

Mayo, 2013

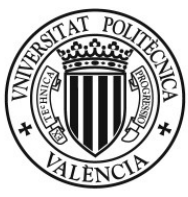

UNIVERSITAT

POLITÈCNICA

DE VALĖNCIA 



\section{ELEMENTOS DISCURSIVOS}

EL PROBLEMA DE LA IDEA de idea de proyecto de obra COMO “OBJETO DE SABER" EN RELACiÓN AL PROYECTO ARTístico

Tesis Doctoral presentada por Bárbaro Julian Miyares Puig Directora Dra. Salomé Cuesta Valera

Programa de Doctorado: Artes Visuales e Intermedia Departamento de Escultura - Facultad de Bellas Artes de Valencia Universitat Politècnica de València

Mayo, 2013

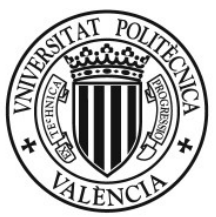

UNIVERSITAT

POLITÈCNICA

DE VALÈNCIA 
Bárbaro Miyares: ELEMENTOS DICURSIVOS: el problema de la idea de idea de proyecto de obra como "objeto de saber" en relación al proyecto artístico, (c) 2013 
"La investigación ¿Qué es una «investigación»? Para saberlo, habría que tener alguna idea sobre lo que es un "resultado». ¿Qué se encuentra? ¿Qué se quiere encontrar? ¿Qué falta? ¿En qué campo axiomático será colocado el hecho liberado, el sentido puesto al día, el descubrimiento estadístico? Sin duda, todo ello depende en cada caso de la ciencia solicitada. Pero desde el momento en que una investigación interesa al texto (y el texto va mucho más lejos que la obra), la investigación se convierte a sí misma en texto, en producción; todo "resultado» le es, al pie de la letra, im-pertinente. La investigación es, entonces, el nombre prudente que, bajo la violencia de determinadas condiciones sociales, damos al trabajo de escritura: la investigación está de parte de la escritura, es una aventura del significante, un exceso del canje; es imposible mantener la ecuación: un "resultado» contra una «investigación». Por ello, la palabra a la que debe someterse una investigación (en el enseñante), aparte de su función parenética («Escribid») tiene como especialidad recordar a la «investigación» su condición epistemológica: no debe, busque lo que busque, olvidar su naturaleza de lenguaje; y esto hace finalmente inevitable reencontrar la escritura. En la escritura, la enunciación decepciona al enunciado bajo el efecto del lenguaje que lo produce: esto define bastante bien el elemento crítico, progresivo, insatisfecho, productor, que el uso común mismo reconoce a la «investigación». Ahí reside el papel histórico de la investigación; enseñar al sabio que habla (pero que, si supiera, escribiría: y toda idea de la ciencia, toda la cientificidad, cambiarían con ello)."

\section{Roland Barthes}

"Ciertas obras y objetos no se pueden exponer mejor que haciendo como que no escribes para nadie, incluso ni siquiera para ti, sino para el objeto enteramente."

Walter Benjamin

"Aquellos que sentían que tenían algo para aprender tenían que estar junto a aquellos que sentían que tenían algo para enseñar".

\section{Joseph Beuys}

Dedicado a la memoria de José Luis Brea y de José Ramón Miyares Puig 



\section{RESUMEN}

ELEMENTOS DISCURSIVOS: el problema de la idea de idea de proyecto de obra como "objeto de saber" en relación al proyecto artístico.

Definimos el objeto de estudio entorno al problema de la idea de idea de proyecto de obra como "objeto de saber" en relación al proyecto artístico. A través de la revisión y el cuestionamiento de la relación práctica artística y universidad, proponemos una metodología denominada elementos discursivos, creando para ello un marco didáctico que recoge la experiencia, el proceso de reflexión y la puesta en práctica tanto en el contexto de la producción artística, la crítica o la docencia. Si consideramos que "la enseñanza del arte es una parte importante de la producción de arte", la formación del artista en la universidad del siglo XXI cobra un lugar relevante sobre las cuestiones que deberíamos problematizar: por ejemplo, ¿qué modelos pedagógicos se utilizan considerando que "el arte es, de hecho, la definición del arte", y qué es, o no, relevante en estos modelos?, ¿el aprendizaje de contenidos o el desarrollo de destrezas cognitivas mediante métodos? ¿Desde los estudios de arte se piensa la idea de universidad, la pertenencia al ámbito de las humanidades? ¿En virtud de qué construimos una obra de arte? o ¿cómo es que se piensa la idea de una obra de arte? De partida, estas preguntas iniciales parecen no ser suficientes al presuponer otras aún más amplias que las abarcan y que en su extensión tratan sobre significados filosóficos, estudios pedagógicos, sociológicos o históricos. Pensamos, sin embargo, que desde nuestra área de conocimiento deberíamos reflexionar sobre los procesos formativos del arte, señalando la necesidad de adquirir -como argumentaba José Luis Brea- "herramientas conceptuales que proporcionen un conocimiento crítico del mundo contemporáneo" y sobre la situación problemática del conocimiento crítico del mundo y por extensión, de las contribuciones del conocimiento artístico a este conocimiento crítico. Por ello llevamos a cabo esta investigación sobre procesos formativos del arte contemporáneo en el contexto universitario con el objetivo de reflexionar sobre las posibilidades de un principio de análisis crítico-disciplinar (de base metodológica), que podría objetivar, conceptual y críticamente los procesos formativos de la idea de idea de proyecto de obra en relación al proyecto artístico. 
Esta metodología didáctica que nombramos "elementos discursivos: el problema de la idea de idea de proyecto de obra como "objeto de saber" en relación al proyecto artístico", concentra (o debería concentrar) algo que de hecho es aún más complejo: ideas, imágenes, hechos y datos de la comprensión del propio elemento (el sujeto), imágenes del pensamiento en las que el artista proyecta su concepción de sí mismo (mundos de vida), y que constituye, en la medida en que organiza su experiencia y, por lo mismo, punto de vista y perspectiva sobre el conocimiento del mundo (realidades del saber).

Entendemos la metodología didáctica de los elementos discursivos como una relación, como un anclaje entre partes cooperantes equilibradas de significación, de ámbitos_sistemas, de producción de criticidad. Aunque podemos hablar de "elementos discursivos" como si fuesen entidades separadas, existen solamente en cuanto componentes_colaborantes de la idea de obra en relación al conocimiento crítico del mundo: por un lado, como inductores potenciales de las funciones semánticas, por otro lado, como referencias exteriores de la mismidad de la cosa idea, y por otro, como subtextos de supuestos implícitos -de proposiciones- sobre la naturaleza de las realidades de saber que la envuelve, $\mathrm{o}$, de la entonces posible realidad de acogida en tanto que operación constructiva transformada en "hecho". Hablamos, por tanto, de una metodología didáctica que piensa la idea de idea de proyecto de obra, de un pensamiento que haría permisible dar mención -bajo el supuesto de una conciencia de la experiencia de obra- a la procesualidad en tanto que forma, también, de producción de conocimiento. Todo esfuerzo por la consolidación de una metodología didáctica de las artes debería concentrar su atención en todo aquello concerniente, y que se da, en la experiencia de la visualidad ("el arte trabaja con ideas plasmadas en un orden de visualidad "), pero también, en las relaciones y flujos de conexión que tienen lugar con los otros órdenes de la experiencia, en la telaraña de su condicionalidad -de la explicación ordenada de las radiaciones que la constituyen y materializan. 


\section{ABSTRACT}

DISCURSIVE ELEMENTS: The problem with the idea of idea building project as "object of knowledge" in relation to the artistic project.

We define the object of study around the issue of project idea idea of work as "object of knowledge" in relation to the art project. Through the review and questioning of artistic practice and university relationship, we propose a methodology called discursive elements, by establishing a learning framework that reflects the experience, the process of reflection and implementation both in the context of production artistic criticism or teaching. If we consider that "art education is an important part of the production of art", the formation of the artist in the XXI century university takes a prominent place on the issues we should problematize: for example, what pedagogical models are used considering that "art is, in fact, the definition of art" and what is or is not, relevant in these models?, does the learning content and the development of cognitive skills through methods? Since art studios thought the idea of the university, membership in the humanities? In virtue of what we build a work of art? or how do you think the idea of a work of art? For starters, these initial questions may not be enough to assume others still larger than the cover and in its philosophical meanings deal extension, pedagogical studies, sociological or historical. We think, however, that since our area of expertise should reflect on the learning processes of art, noting the need to purchase -as argued José Luis Brea-"conceptual tools that provide a critical understanding of the contemporary world" and the problematic situation critical knowledge of the world and by extension, artistic knowledge contributions to this critical knowledge. Therefore we conducted this research on learning processes of contemporary art in the university context in order to reflect on the possibilities of a principle of critical-disciplinary analysis (based methodology), which could objectify critically conceptual and formative processes the idea of idea of project work in relation to the art project.

This teaching methodology named "discursive elements: the problem of the idea of building project idea as" object of knowledge "regarding the artistic project", concentrated (or should focus) which in fact is even more complex: ideas, pictures, facts and understanding data element itself (the subject), images of thought in which the artist projects his conception of himself (worlds of life), 
and that is, to the extent that organizes their experience and therefore, point of view and perspective on world knowledge (realities of knowledge).

We understand the teaching methodology of the discursive elements as a relationship, as an anchor between cooperating parties balanced significance of ámbitos_sistemas, criticality production. Although we speak of "discursive elements" as if they were separate entities exist only as the idea componentes_colaborantes work in relation to critical knowledge of the world: first, as potential inducers of semantic functions, on the other hand, as references external sameness of the thing thought, and secondly, as subtexts of implicit assumptions-of propositions-on the nature of the reality of knowing that surrounds it, or actually the host then possible while transformed into constructive operation "fact". We are therefore, a teaching methodology that think the idea works project idea, a thought that would permissible to mention, under the assumption of a consciousness of the experience of work-to processuality form while also of knowledge production. Any effort by the consolidation of the arts teaching methodology should concentrate on everything concerning, and given, in the experience of visuality ("art works with ideas in an order of visuality"), but also, in relationships and connection flows that take place with the other orders of experience in the web of conditionality-ordinate the explanation of radiation that constitute and embody. 
ELEMENTS DISCURSIUS: el problema de la idea d'idea de projecte d'obra com "objeto de saber" en relació al projecte artístic.

Definim l'objecte d'estudi al voltant del problema de la idea d'idea de projecte d'obra com a "objecte de saber" en relació al projecte artístic. A través de la revisió i el qüestionament de la relació pràctica artística i universitat, proposem una metodologia denominada elements discursius, creant per a això un marc didàctic que arreplega l'experiència, el procés de reflexió i la posada en pràctica tant en el context de la producció artística, la crítica o la docència. $\mathrm{Si}$ considerem que "la ensenyança de l'art és una part important de la producció d'arte", la formació de l'artista en la universitat del segle XXI cobra un lloc rellevant sobre les qüestions que hauríem de problematitzar: per exemple, quins models pedagògics s'utilitzen considerant que "el art és, de fet, la definició de l'arte", i què és, o no, rellevant en estos modelos?, l'aprenentatge de continguts o el desenrotllament de destreses cognitives per mitjà de mètodes? Des dels estudis d'art es pensa la idea d'universitat, la pertinença a l'àmbit de les humanitats? En virtut de què construïm una obra d'art? o com és que es pensa la idea d'una obra d'art? De partida, estes preguntes inicials pareixen no ser suficients al pressuposar altres encara més àmplies que les comprenen i que en la seua extensió tracten sobre significats filosòfics, estudis pedagògics, sociològics o històrics. Pensem, no obstant això, que des de la nostra àrea de coneixement hauríem de reflexionar sobre els processos formatius de l'art, assenyalant la necessitat d'adquirir -com argumentava José Luis Brea"herramientas conceptuals que proporcionen un coneixement crític del món contemporáneo" i sobre la situació problemàtica del coneixement crític del món i per extensió, de les contribucions del coneixement artístic a este coneixement crític. Per això duem a terme esta investigació sobre processos formatius de l'art contemporani en el context universitari amb l'objectiu de reflexionar sobre les possibilitats d'un principi d'anàlisi criticodisciplinar (de base metodològica) , que podria objectivar, conceptual i críticament els processos formatius de la idea d'idea de projecte d'obra en relació al projecte artístic.

Esta metodologia didàctica que anomenem "elementos discursius: el problema de la idea d'idea de projecte d'obra com "objeto de saber" en relació al projecte artístico", concentra (o hauria de concentrar) quelcom que de fet és 
encara més complex: idees, imatges, fets i dades de la comprensió del propi element (el subjecte), imatges del pensament en què l'artista projecta la seua concepció de si mateix (mons de vida), i que constituïx, en la mesura que organitza la seua experiència $i$, pel mateix, punt de vista i perspectiva sobre el coneixement del món (realitats del saber).

Entenem la metodologia didàctica dels elements discursius com una relació, com un ancoratge entre parts cooperants equilibrades de significació, d'ámbitos_sistemas, de producció de criticidad. Encara que podem parlar de "elementos discursivos" com si anessen entitats separades, existixen només en quant componentes_colaborantes de la idea d'obra en relació al coneixement crític del món: d'una banda, com inductors potencials de les funcions semàntiques, d'altra banda, com a referències exteriors de la mismidad de la cosa idea, i d'un altre, com subtextos de supòsits implícits -de proposicionssobre la naturalesa de les realitats de saber que l'embolica, o, de la llavors possible realitat d'acollida en tant que operació constructiva transformada en "hecho". Parlem, per tant, d'una metodologia didàctica que pensa la idea d'idea de projecte d'obra, d'un pensament que faria permissible donar menció -baix el supòsit d'una consciència de l'experiència d'obra- a la procesualidad en tant que forma, també, de producció de coneixement. Tot esforç per la consolidació d'una metodologia didàctica de les arts hauria de concentrar la seua atenció en tot allò concernent, i que es dóna, en l'experiència de la visualitat ("el art treballa amb idees plasmades en un orde de visualitat "), però també, en les relacions i fluxos de connexió que tenen lloc amb els altres ordes de l'experiència, en la teranyina de la seua condicionalitat -de l'explicació ordenada de les radiacions que la constituïxen i materialitzen. 


\section{PUBLICACIONES}

AUTOR(p.o. de firma): Salomé Cuesta; Bárbaro Miyares;

TÍtulo: Cultura_responsabilidad_universidad

EDITORIAL: CENDEAC

REF. REVISTA/LIBRO (ISBN, ISSN, SUPV): Estudios Visuales (ISSN 16987470)

VOLUMEN PÁGINAS: 123 - 133 AÑO: 2004 CLAVE: A

AUtor (p.o. de firma): Cuesta Valera, María Salomé; Miyares Puig, Bárbaro Julián;

Título: Cuesta, Salomé E Miyares, Bárbaro

EDITORIAL: Servicio de Publicaciones Universidad de Vigo

REVISTA/LIBRO (ISBN, ISSN, SUPV): ARTE: DICCIONARIO ILUSTRADO (ISBN 978-84-8158-570-4)

VOLUMEN: 24 PÁGINAS: 116 - 119 AÑO: 2012 CLAVE: CL

AUToR (p.o. de firma): Cuesta Valera, María Salomé; Miyares Puig, Bárbaro Julián;

Título: Producción E Registro en la obra de Vicente Ortí

EDITORIAL: EMAT. Ajuntament de Torrent

REF. REVISTA/LIBRO (ISBN, ISSN, SUPV): La pedra, la fusta i el ferro (ISBN 978-84-939709-0-1)

VOLUMEN: 2 PÁGINAS: 18 - 22 AÑO 2012 ClAVE: CL

AUTOR (p.o. de firma): Salomé Cuesta; Bárbaro Miyares

TítUlo: La formación en ACT

EDITORIAL: FECYT

REF. REVISTA/LIBRO (ISBN, ISSN, SUPV): Libro Blanco de la interrelación entre Arte, Ciencia y Tecnología en el Estado español (ISBN 9788469035207)

VOLUMEN: 3 PÁGINAS: 17 - 29 AÑO: 2007 CLAVE: CL 
AUTOR (p.o. de firma): Salomé Cuesta; Bárbaro Miyares;

Título: Enmarcando el ver/escenificando la visión

EDITORIAL : Consejería de Educación y Cultura. Centro Párraga

REF. REVISTA/LIBRO (ISBN, ISSN, SUPV): Laboratorio de luz. Especulaciones

a un tiempo (ISBN 978-84-606-3911-4)

VOLUMEN: 3 PÁGINAS: 15 - 19 AÑO: 2006 CLAVE: CL

AUTOR (p.o. de firma): Salomé Cuesta; Bárbaro Miyares

TÍ́tulo: Del disparo del duelo

EDITORIAL : Conselleria de Cultura, Educació i Esport

REF. REVISTA/LIBRo (ISBN, ISSN, SUPV): Del mono azul al cuello blanco. Transformación social y práctica artística en la Era Postindustrial (ISBN 84-482-3594-0)

VOLUMEN: 15 PÁGINAS: 166 - 171 AÑO: 2003 CLAVE: CL

\section{Artículos en revistas impresas y electrónicas}

AUTORES (p.o. de firma): Guadalupe Álvarez, Bárbaro Miyares, Pedro Álvarez, L. Gómez, Carlos Garaicoa, Gerardo Mosquera, M. Izquierdo Título: Proyecto Nada, en Arte: proyectos e ideas editorial: Universidad Politécnica, Valencia REF. REVISTA/LIBRO (ISBN, ISSN, SUPV): 84-600-8322-5 CLAVE: A VOLUMEN: 1 PÁGINAS: 129-131 AÑO: 1993

Título: La casa en la frontera de Emilio Martínez ORGANISMO: http:// www.artszin.net AÑO: 2000

TÍTULO: Entre las franjas blancas PUBLICADO EN: Entre las franjas blancas. Texto del proyecto MATRICE para el catálogo RIRKRIT TIRAVANIJA.

EVENTO CONTINUO: PROPUESTAS DE ARTE PÚBLICO PARA 
MADRID. Galería Salvador Díaz. Madrid AÑo: 2000

URL: http://tinyurl.com/39apqnv

Título: La casa en la frontera, de Emilio Martínez

PUBLICADO EN: EN artszin.net AÑO: 2000

URL: http:/ /www.artszin.net/volı/martinez.html

Título: Mabel Palacín: Sur l'autoroute

PUBLICADO EN: artszin.net AÑO: 2000

URL: http://tinyurl.com/26yoqkg

Tírulo: Localizaciones: la huella que huye (de Elisabet Merino y Francisco Sanmartín)

PUBLICADO EN: artszin.net AÑO: 2001

URL: http://tinyurl.com/34pnydq

Título: Del paso primario a la aventura posible.

PUBLICADO EN: artszin.net AÑO: 2001

URL: http://tinyurl.com/2vzgab7

Título: De este lado del puente: sustituir la huída (de Esterio Segura)

PUBLICADO EN: artszin.net AÑO: 2001

URL: http://tinyurl.com/358jtvw

Título: El reproductor (de Duvier del Dago)

PUBLICADO EN: artszin.net AÑO: 2001

URL: http://tinyurl.com/358jtvw

TÍtUlo: En torno a la ilusoriedad: cinco maneras del ver posible

PUBLICADO EN: artszin.net AÑO: 2001

URL: http://tinyurl.com/3xo7sfz

Título: Extraño cuerpo de color (Experiencia de relacionar X) (2001)

publicado en: ALBUR. Daniel Urta. Bárbaro Miyares (V. 1977-2001). 
Ayuntamiento de Alfafar (Valencia) AÑo: 2001.

TÍTULo: Interiores: del gusto por lo concupiscible

PUBLICADO EN: artszin.net AÑO: 2002

URL: http:/ / tinyurl.com/38cwy34

Título: Filo fino: la exposición imaginaria de Jorge Luis Hernández Pouyo

PUBLICADO EN: artszin.net AÑO: 2002

URL: http://tinyurl.com/389sewy

Título: La Pared de Cristal de Dora García: acción \& propósito.

PUBLICADO EN: artszin.net AÑO: 01/o2

URL: http:/ / tinyurl.com/323uaon

Título: Un móvil en la patera: la pluma inexacta

PUBLICADO EN: artszin.net AÑO: 2000

URL: http:/ /www.artszin.net/volı/martinez.html

Título: El filo de María, ¿una exposición real?

PUBLICAdo EN: NONSITE N 1 (ISSN:1697-6657) AÑO 2003

URL: http:/ / tinyurl.com/399qodb

Título: Observación: Escrito sobre piedra

PUBLICADO EN: NONSITE No 3 (ISSN:1697-6657) AÑo: 2003

URL: http:/ / www.artszin.net/volı/martinez.html

Título: De gestos y memorias: de lo que 'carga' arrastra

PUBLICADO EN: Loreta Visic. Instituto de la Juventud (84-96028-03-8) AÑo: 2003

URL: http://tinyurl.com/33aasfq

TÍTULO: Bathroom action: acontecimientos de los usos

PUBLICADO EN: The Flators: Suzanne Dér y Anthony Burnham. Instituto de la Juventud(84-96028-02-X) AÑo: 2003

URL: http:/ / tinyurl.com/399qodb 
TÍtulo: Front I, II y III

PUBLICADO EN: Artecontexto (1697-2341) AÑO: 2004

URL: http:/ / arteycontexto.com

Título: Arts al Palau, Maribel Domenech

publicado en: Arts al Palau 2004 Ayuntamiento de Gandia (Valencia)

AÑO: 2004

URL: http:/ /artsalpalu.com

Título: Varia la luz y el color (amarillo/azul) (2005)

pUblicado en: Arts al Palau 2005 Ayuntamiento de Gandia (Valencia) AÑO: 2005

URL: http:/ /artsalpalau.com

Título: Experiencia de relacionar: ciudadano-lugar

PUBLICADO EN: Estiu Art intervencions (84-9705-990-5) AÑO: 2006

URL: http://sacuesta.webs.upv.es/intervenciones.htm

Título: De la imagen: lo que nos mira

PUBLICADO EN: salonKritik AÑO: 2008

URL: http:/ / tinyurl.com/2un7zmp

Título: Eve Sussman \& Rufus Corporation: en el filo ideológico de las formas cinematográficas de gestión productiva

PUBLICADO EN: salonKritik AÑO: 2008

URL: http://tinyurl.com/325qqs5

Título: Sobre Mineralidad absoluta / Retrato otro de José Luis Brea

PUBLICADO EN: salonKritik AÑO: 2010

URL: http:/ / tinyurl.com/35lfsad 



\section{AGRADECIMIENTOS}

A toda mi familia -la de aquí y la de allí.

A la paciencia de Bárbara y Abraham, y también, a mi directora, compañera... 



\section{ÍNDICE GENERAL}

I INTRODUCCIÓN I

I INTRODUCCIÓN 3

1.1 Estado de la cuestión: problemas, principios y categorías. 4

1.1.1 Pensar los límites. $\quad$ II

1.1.2 Condiciones del problema. 13

II PAISAJE TEÓRICO 19

2 PAISAJE TEÓRICO 21

2.1 La teoría, por su uso, distingue lo que la práctica confunde 22

2.2 Foco de la investigación 29

2.3 Proyectos de inserción socio-cultural 34

2.4 Práctica artística y universidad: una cosa y otra. 38

2.4.1 Interrelación Arte-Ciencia-Tecnología en el estado español. $\quad 40$

2.4.2 Libro Blanco de la investigación en Humanidades 41

2.4.3 Los ordenes institucionales son formas del espíritu objetivo. 42

2.4.4 El debate que sobre la Universidad nos urge $\quad 46$

2.4.5 La cuestión de la relación práctica artísticauniversidad 50

2.4.6 Sobre la evidencia del desajuste entre "función social real" e "idea regulativa". 55

2.5 Cultura_responsabilidad_universidad 59

2.5.1 La irreversible transformación. 61

2.5.2 Responsabilidad, cosmopolitismo, ciudadanía. 63

2.5.3 Filo ciego: el espacio por ser 66 


\subsubsection{Imagen de la Universidad 68}

\section{CUADRO DIDÁCTICO 71 \\ 3 CUADRO DIDÁCTICO 73}

3.1 El individuo en el arte 74

3.2 Enmarcando el ver / Escenificando la visión 95

3.3 Trazar un plan conforme a un fin 102

3.3.1 La idea desde el inicio: construirla es entenderla. 104

3.4 Los fundamentos tempranos de la experiencia 107

3.4.1 Por una idea base de "experiencia" 109

3.4.2 Modos de relación \& experiencia de relacionar 110

3.5 Problema del conocimiento en las prácticas artísticas 117

3.5.1 Idea de Idea de obra 119

3.5.2 El objeto artístico no es significativo por ser universal 120

3.6 Útil, entidad, suyo propio 124

3.7 Plano de triangulación operacional 126

3.7.1 El sistema: La posibilidad de pensarlo 134

3.8 Metodología y Método: sujetos a una base ideológica 136

3.8.1 Método, metodología, procedimiento 137

3.9 Carácter exhaustivo del método 140

3.9.1 Principio de verificación 142

3.10 Conocimiento de Principio 148

3.10.1 Reabrir la cuestión gnoseológica respecto a los procesos creativos 151

3.11 La didáctica de los elementos discursivos 155

3.11.1 La cadena Md-cR-Ce 158

3.11.2 De los Elementos discursivos: clave metodológica 160

3.11.3 Los elementos discursivos son enunciados operacionales $\quad 164$ 
3.11.4 Primeros elementos discursivos. 171

3.11.5 Contenedores genéricos de elementos discursivos 173

3.11.6 Condicionales previos a los elementos discursivos 174

3.12 Ejemplo: Problema $1 \quad 179$

3.12.1 Solución al problema $1 \quad 180$

3.12.2 Esquematización de comportamiento 183

3.12.3 Niveles esquemáticos de la idea de proyecto. 184

3.12.4 Esquema o diagnóstico de los elementos iniciales 184

IV CONCLUSIONES 193

4 A Modo de conclusiones 195

4.1 De la Praxeología necesaria 196

4.1.1 El marco 197

4.1.2 La observación de Bédard 200

4.1.3 Camnitzer y la relación arte y enseñanza. 203

4.1.4 Una lógica de inclusión/exclusión 204

4.1.5 De lo que nos interesa 207

4.1.6 La estrategia Praxeológica 211

4.1.7 La universidad actual diseña de algún modo el tipo de individuo de apoyo 212

4.1.8 Los individuos de apoyo enclasados 214

4.1.9 El rombo de Bédard y la praxeología que nos interesa 216

V APÉNDICE 227

A ESCRIBIR LOS MOdOS DE PRÁCtICAS 229

A.1 Proyecto Nada 230

A.2 Sobre Caribe inexplorado, de Belkis Ramírez 234

A.3 Entre franjas blancas 237

A.4 La casa en la frontera, de Emilio Martínez 243

A.5 Mabel Palacín: Sur l'autoroute 247 
A.6 Localizaciones: la huella que huye 251

A.7 Del paso primario a la aventura posible 260

A.8 Desde este lado del puente: sustituir la huida 266

A.9 El reproductor 270

A.1o En torno a la ilusoriedad: cinco maneras del ver posible 275

A.11 Extraño cuerpo de color 278

A.12 Filo fino: exposición de Jorge Luis H. Pouyo 281

A.13 La Pared de Cristal de Dora García: acción \& propósito 284

A.14 Un móvil en la patera: la pluma inexacta 289

A.15 El filo de María, ¿una exposición real? 294

A.16 Observación: Escrito sobre piedra 299

A.17 De gestos y memorias: de lo que 'carga' arrastra 302

A.18 Bathroom action: acontecimientos de los usos 305

A.19 Front I, II y III 308

A.20 Arts al Palau: varias sospechas, una afirmación 310

A.21 Varia la luz y el color (amarillo/azul) 318

A.22 Experiencia de relacionar: ciudadano-lugar 321

A.23 De la imagen: lo que nos mira 323

A.24 Eve Sussman \& Rufus Corporation 327

A.25 Javi Moreno: en ese necesario vértice creativo 336

A.26 Sobre Mineralidad absoluta/ Retrato otro de José Luis Brea 339

A.27 Producción \& registro 342

B FilMar los MOdos De La CRítica 347

B.1 Román de la Calle 350

B.2 Ricardo Forriols 351

B.3 Elena Vozmediano 352

B.4 Nilo Casares 353

B.5 Domingo Mestre 354

B.6 José Luis Clemente 355

B.7 Rocío de la Villa 356

B.8 Álvaro de los Ángeles 357

B.9 Miguel Ángel Hernández-Navarro 358 
B.10 Mieke Bal 359

B.11 Juan Luis Moraza 360

B.12 Juan Bautista Peiró 361

B.13 Juan Vicente Aliaga 362

B.14 David Pérez 363

B.15 Daniel García Andújar 364

B.16 Rosa Olivares 365

B.17 José Luis Brea 366

B.18 Manuel Borja-Villel 367

B.19 José Miguel G. Cortés 368

B.20 Fernando Castro 369

B.21 Pau Rausell 370

B.22 Martí Peran 371

BIBLIOGRAFÍA 373 


\section{ÍNDICE DE FIGURAS}

Figura 1

Figura 2

Figura 3

Figura 4

Figura 5

Figura 6

Figura 7

Figura 8

Figura 9

Figura 10

Figura 11

Figura 12

Figura 13

Figura 14

Figura 15

Figura 16

Figura 17

Figura 18

Figura 19
Joseph Kosuth, (Art as Idea as Idea) The Word "Art", 1966-68.

Fotografía. $144.8 \times 144.8 \mathrm{~cm}$ 7

Robert Smithson A heap of language (Una pila de lenguaje), 1966.

$$
7
$$

Terry Atkinson y Michael Baldwin, Empty Pieces (Piezas Vacias), 1967

$$
8
$$

Joseph Beuys en el aula. $\quad 9$

Esquema sujeto de conocimiento/procesos de interacción $\quad 100$

Esquema de la secuencia (1) relativa el sujeto gnoseológico artista y el proceso de detección. 106

Esquema de la secuencia (2) relativa el sujeto gnoseológico artista y el proceso de detección. $\quad 109$

Cuadro de equivalencia del modelo de Cierre Categorial (de Gustavo Bueno) y en modelo de relación Universo Arte-Mundo arte 122

Teoría del cierre categorial de Gustavo Bueno 123

Esquema de la relación Universo Arte-Mundo arte. 123

Esquema plano de triangulación operacional 126

Esquema de Philip Wheelwright 127

Plano triangulación operacional de partida (1) 133

Mapa del conocimiento $\quad 148$

Esquema de cadena ordenativa a partir del Plano operacional $\quad 157$ Esquema primeros elementos discursivos 173

Desde la «pieza» a la «obra»: dos sistemas de producción y recepción del arte. (Cuadro de Becq) 175

Obras de Marta Miranda y Elba Jiménez $\quad 176$

Diego Rivera. Brading of Indians e Historia de México, 1929-1945.

Fresco. Palacio Nacional de México 177 
Figura 20

Figura 21

Figura 22

Figura 23

Figura 24

Figura 25

Figura 26

Figura 27

Figura 28

Figura 29

Figura 30

Figura 31

Figura 32

Figura 33

Figura 34

Figura 35

Figura 36

Figura 37

Figura 38

Figura 39

Figura 40

Figura 41

Figura 42

Figura 43
Justo Clemente Orozco. Épica de la civilización Americana, 1932-34. Baker Library. New York. David Alfaro Siqueiro. Humanidad vs. Cosmos, 1964. 177

David Alfaro Siqueiro. The Devil in the Church, $1947 \quad 177$

Marcel Duchamp. La mariée mise à $n u$ para ses célibataires, même (El gran vidrio), 1915-23, Nueva York. Fracturada en 1926, restaurada en 1936 - Esquema de los elementos de El gran vidrio, por Jean Suquet, 1998. 178

Joseph Beuys. Unterrichtstafel aus dem Büro für Direkte Demokratie (Blackboard from the Office for Direct Democracy), 1971 - Robert Smithson. Espiral Jetty, 1970. Gran Lago Salado, Utah. $\quad 178$

Esquema de comportamiento ejemplo $1 \quad 181$

Esquema de comportamiento ejemplo 2 181

Esquema de comportamiento ejemplo $3 \quad 182$

Joseph Kosuth. Una y tres sillas, 1965 - Joseph Beuys. Silla de grasa, $1963 \quad 182$

Estado cognoscente del paisaje social común y acción cognitiva individual para la detección de los elementos discursivos. 183 Del elemento discursivo al sistema significación: resultado de relación 'estado cognoscente' de la estructura social y 'acción cognitiva' individual 183

Niveles esquemáticos de la idea de proyecto $\quad 184$

Esquema funcionamiento I 188

Esquema de funcionamiento II 190

El rombo filosófico de Bédard $\quad 197$

La praxeología de R. Bédard 217

Descripción del comportamiento del proyecto 233

La casa en la frontera. Instalación $\quad 245$

Sur L’autoroute 247

La huella que huye I 252

La huella que huye II 254

Armonía de contrarios y el diseño de lo híbrido 260

Román de la Calle - Crítico de arte. $\quad 350$

Ricardo Forriols - crítico de arte 351

Elena Vozmediano - Crítica de arte 352 
xxviii Índice de figuras

\begin{tabular}{|c|c|}
\hline Figura 44 & Nilo Casares - crítico de arte \\
\hline Figura 45 & Domingo Mestre - artista y escritor \\
\hline Figura 46 & José Luis Clemente - crítico de arte $\quad 355$ \\
\hline Figura 47 & Rocío de la Villa - crítica de arte 356 \\
\hline Figura 48 & Álvaro de los Ángeles - crítico de arte 357 \\
\hline Figura 49 & $\begin{array}{lllll}\text { Miguel Ángel Hernández-Navarro } & \text { - Escritor y crítico } \\
\text { arte } & 358 & & & \end{array}$ \\
\hline Figura 50 & Mieke Bal - teórica y crítica cultural 359 \\
\hline Figura 51 & Juan Luis Moraza - artista y profesor $\quad 360$ \\
\hline Figura 52 & Juan Bautista Peiró - Crítico de arte 361 \\
\hline Figura 53 & Juan Vicente Aliaga - crítico y comisario 362 \\
\hline Figura 54 & David Pérez - Crítico de arte 363 \\
\hline Figura 55 & Daniel García Andújar - artista visual y activista \\
\hline Figura 56 & Rosa Olivares - crítica de arte y directora de EXIT \\
\hline Figura 57 & José Luis Brea - crítico de arte y comisario 366 \\
\hline Figura 58 & Manuel Borja-Villel / Director MNCARS 367 \\
\hline Figura 59 & José Miguel G. Cortés /Comisario y escritor 368 \\
\hline Figura 60 & Fernando Castro - Crítico y comisario $\quad 369$ \\
\hline Figura 61 & Pau Rausell - Investigador Economía Aplicada a la Cultura \\
\hline Figura 62 & Martí Peran - Crítico y comisario \\
\hline
\end{tabular}


AAVC: Associació d'artistes Visuals de Catalunya

Аст: Arte, Ciencia y Tecnología

ASCA: Amsterdam School for Cultural Analysis

сссв: Centro Cultura Contemporánea de Barcelona

CE: Entorno o contexto

Cendeac: Centro de Documentación y Estudios Avanzados de Arte Contemporáneo

CR: Conectores de relación

EACC: Espai d'art contemporani de Castelló

EDI: Elementos discursivos iniciales

ED: Elementos discursivos

FECYT: FECYT

GREPH: Grupo de Investigación para la Enseñanza de la Filosofía

grofau: Grupo de Reflexión y Opinión sobre la Formación Artística Universitaria

IAC: Instituto de Arte Contemporáneo

ICAIC: Instituto Cubano de Arte e Industria Cinematográficos

IVAM: Instituto Valenciano de Arte Moderno

KNAW: Royal Netherlands Academy of Arts and Sciences 
масва: Museo de Arte Contemporáneo de Barcelona

MAv: Mujeres en Artes Visuales

MD: Modelo disciplinar

MDDED: Metodología de Detección de los Elementos Discursivos

mnCARs: Museo Nacional de Arte Contemporáneo Reina Sofía

Muvim: Museu Valencià de la Il.lustració i de la Modernitat

PCA: Plano de los Conocimientos Anteriores

pRCIO: Plano de la Reducción de una clase de identidades a otras

upv: Universidad Politécnica de Valencia 
Parte I

INTRODUCCIÓN 



\section{INTRODUCCIÓN}

"El peligro del Método (de una fijación en el Método) proviene de esto: el trabajo de investigación debe responder a dos demandas; la primera es una demanda de responsabilidad: el trabajo tiene que acrecentar la lucidez, conseguir desenmascarar las implicaciones de un procedimiento, las coartadas de un lenguaje; constituir, en suma, una crítica (recordemos una vez más que criticar quiere decir poner en crisis); aquí el Método es inevitable, irreemplazable, no por sus «resultados», sino precisamente -o por el contrario- porque realiza el más alto grado de conciencia de un lenguaje que no se olvida a sí mismo; pero la segunda demanda es de un orden muy distinto; es la de la escritura, espacio de dispersión del deseo, donde se da licencia a la ley; por tanto, en un cierto momento, hay que revolverse contra el Método, o, al menos, tratarlo sin privilegio fundador, como una de las voces del plural: como una vista; en suma, un espectáculo engastado en el texto; texto, que, después de todo, es el único resultado "verdadero» de toda investigación..."

Roland Barthes 


\subsection{ESTAdo DE LA CUESTIÓN: PROBLEMAS, PRINCIPIOS Y CATEGORÍAS.}

En el texto "El arte del futuro (y su urgente enseñanza)", José Luis Brea plantea la necesidad de adaptar los procesos formativos, señalando la necesidad de adquirir "herramientas conceptuales que proporcionen un conocimiento crítico del mundo contemporáneo, necesario para que esa inserción en los ámbitos de las nuevas industrias del imaginario colectivo no diluya la función del artista en la de un mero entretenedor, sino que refuerce sus potenciales de producción simbólica en la capacitación para el desarrollo de instrumentos de autorreflexión y criticidad." ${ }^{1}$ En más de una ocasión nos hemos preguntado sobre las posibilidades de dar respuesta a cuestiones como la situación problemática del conocimiento crítico del mundo y por extensión, de las contribuciones del conocimiento artístico a este conocimiento crítico. ¿En virtud de qué construimos una obra de arte? o ¿Cómo es que se piensa la idea de una obra de arte? De partida, estas dos preguntas iniciales parecen no ser suficientes al presuponer otras aún más amplias, que las abarcan, y que en su extensión tratan sobre significados filosóficos de lo inmaterial -cuestiones como el espírituen tanto que concepto disociado de la realidad mundana. Pero, ¿es acaso el espíritu esa virtud, es el espíritu ese cómo que da resolución a la idea de obra de arte? Tal vez solicitando de nosotros una cierta prudencia, nada arrogante pero sí contundente, Hans Jörg Sandkühler nos expone en el prólogo de la edición española de su libro Mundos posibles: nacimiento de una nueva mentalidad científica ${ }^{2}$, algo así como los límites y peligros de una empresa de tal magnitud: "todavía necesitamos comprender cómo es posible saber algo y qué es lo que sabemos cuando afirmamos conocer la realidad". Con prudencia y cautela, aunque no sin ambición emprenderemos el camino hacia una metodología didáctica no del saber específico de la cuestión "saber artístico" pero sí sobre una metodología de aproximación a la cuestión de como la obra de arte aporta o es -en

1 BREA, J.L. "El arte del futuro (y su urgente enseñanza)". Edición online: http:/ / tinyurl.com/p2gmwal (4/10/2011)

2 SANDKÜHLER, H. J., Mundos posibles: nacimiento de una nueva mentalidad científica. Ediciones Akal, 1999. 
definitiva, emprenderemos el camino hacia las realidades del saber que toda aproximación al arte descubre y enseña.

La primera aclaración pertinente corresponde al uso del concepto realidades del saber, entendido desde el punto de vista que le otorga la epistemología del realismo interno desarrollado por Sandkühler, que se ocupa de la relación entre realidad y saber, ejerciendo, según él, un panorama cooperativo de realidades, de la realidad, visibles entonces y analizables por tanto: "Vivimos en realidades del saber." 3

Esta metodología didáctica que denominamos de elementos discursivos concentra, o debería concentrar, algo que de hecho es aún más complejo: ideas, imágenes, hechos y datos de la comprensión del propio elemento (el sujeto), imágenes del pensamiento en las que el artista proyecta su concepción de sí mismo (mundos de vida), y que constituye, en la medida en que organiza su experiencia y, por lo mismo, punto de vista y perspectiva sobre el conocimiento del mundo (realidades del saber).

El problema que plantea nuestro esfuerzo -y aquí nos enfrentaríamos con ese realismo del conocimiento generalmente confundido con el neoplatonismo, marcado por la creencia en la realidad del mundo exterior y en la objetividad fundamental de los sentidos que cada individuo puede darle- consiste en acotar los principios y categorías que nos permitirán desarrollar una investigación que concluya como resultado en una propuesta de acción pedagógica, entendida esta como una reflexión entorno a la metodología de la formación en tanto que forma de conocimiento del saber del arte; este interés inicial, por el proceso creativo ha sido desarrollado por diferentes autores y desde múltiples enfoques, que obviamente han contribuido a enmarcar los interés de esta investigación y a establecer criterios. Nos referimos, en primer lugar, a la celebre conferencia de Marcel Duchamp, pronunciada en 1957, en la que se proponía hallar un "coeficiente de arte". Las preguntas formuladas al estilo de: “cómo puede uno describir el fenómeno que lleva al espectador a reaccionar críticamente frente a una obra de arte? o del tipo, ¿cómo es que surge esta reacción?" constituyen el momento inicial y de transformación de las teorías encargadas del estudio de la experiencia

3 Íbidem. 
artística y en el mismo orden, y por extensión, de la práctica artística en general.

La aproximación que plantea Duchamp en relación al proceso creativo, del orden de: intención-realización-reacciones subjetivas, da lugar finalmente a la siguiente ecuación:

“... esta diferencia entre lo que intentó realizar y lo que realizó, es el "coeficiente de arte" personal, contenido en la obra.

En otras palabras, el "coeficiente de arte" personal es como una relación aritmética entre lo inexpresivo pero intentado y lo no intencionalmente expresado."

Consideramos que la reflexión final del "El acto creativo"4 plantea un nuevo modo de comprensión y acercamiento al hecho artístico, en tanto que atribuye competencias y responsabilidades al espectador, transformando con ello, la tradición interpretativa:

"En general, el acto creativo no es ejecutado por el artista solo; el espectador lleva la obra al contacto con el mundo externo, al descifrar e interpretar sus cualidades internas, de esta manera añadiendo su contribución al acto creativo."

La transformación que opera este postulado afecta tanto a la historia de la estética como al momento y lugar desde el que se ha de iniciar cualquier reflexión entorno a la práctica artística. Desde esta convicción partimos para desarrollar nuestra investigación, es a través del acto creativo formulado por Duchamp donde, como menciona José Luis Brea5: "las categorías centrales de toda la estética occidental -las del autor, obra y representación- se abocan a una crisis abierta." Crisis en la consideración del arte en tanto que forma de conocimiento y crisis en la enseñanza del arte en tanto que cuestionamiento del acto creativo.

Son múltiples las declaraciones de autores que a través de sus prácticas podrían servir como referencia, pensemos por ejemplo en las

4 Duchamp, MArcel. Escritos : Duchamp du Signe . Ed. G. Gili, Barcelona, 1978. Pág. 128

5 BREA, JOsÉ LUIS. "Releyendo el acto creativo (por un $<<$ escribismo iluminador $>>$ )" publicado en Nuevas estrategias alegóricas. Ed. Tecnos, Madrid, 1991. Pág. 27. 
aportaciones de Joseph Kosuth cuando afirmaba: "Puesto que el arte es la enseñanza del arte, ..."

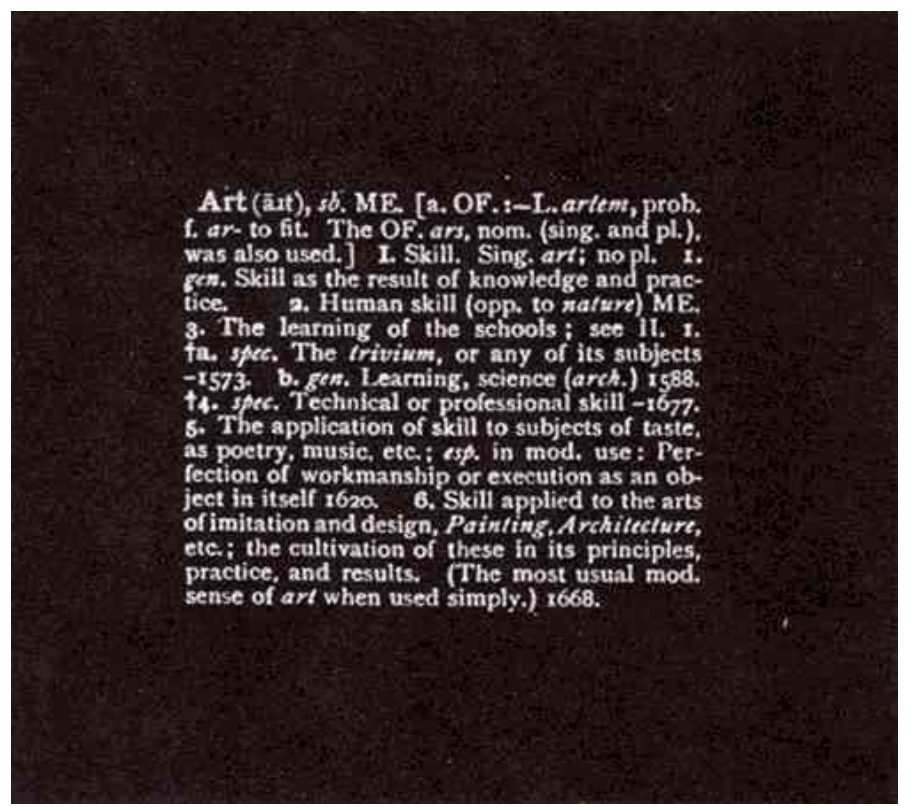

Figura 1: Joseph Kosuth, (Art as Idea as Idea) The Word "Art", 1966-68. Fotografía. 144.8 x $144.8 \mathrm{~cm}$

La importancia del lenguaje y de su relación con el significado de una serie de conceptos (lenguaje, fraseología, discurso, lengua, etc) que son apilados en esta obra de Robert Smithson

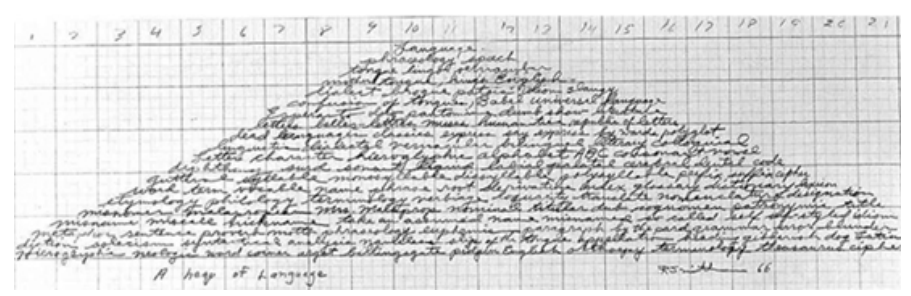

Figura 2: Robert Smithson A heap of language (Una pila de lenguaje), 1966. 
El grupo Art \& Language, con su serie de cartografías tautológicas en tanto que investigaciones sobre la naturaleza del concepto arte, influenciados por Wittgenstein o Carnap donde aparece un desplazamiento entre la investigación artística y el lenguaje, lenguaje que es utilizado de un modo analítico y donde la obra se constituye como un sistema cerrado que a su vez, construye su propia definición.

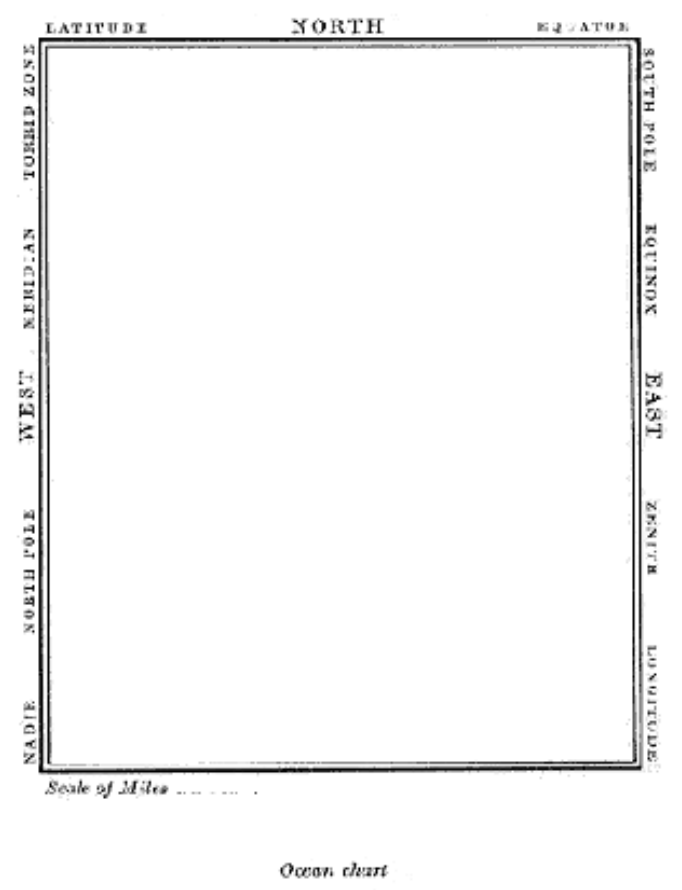

Figura 3: Terry Atkinson y Michael Baldwin, Empty Pieces (Piezas Vacías), 1967

Entender la responsabilidad de ser maestro como una extensión de la práctica artística, proponiendo incluso la formación de una "Universidad Libre Internacional" como hiciera, en 1973, Joseph Beuys. 


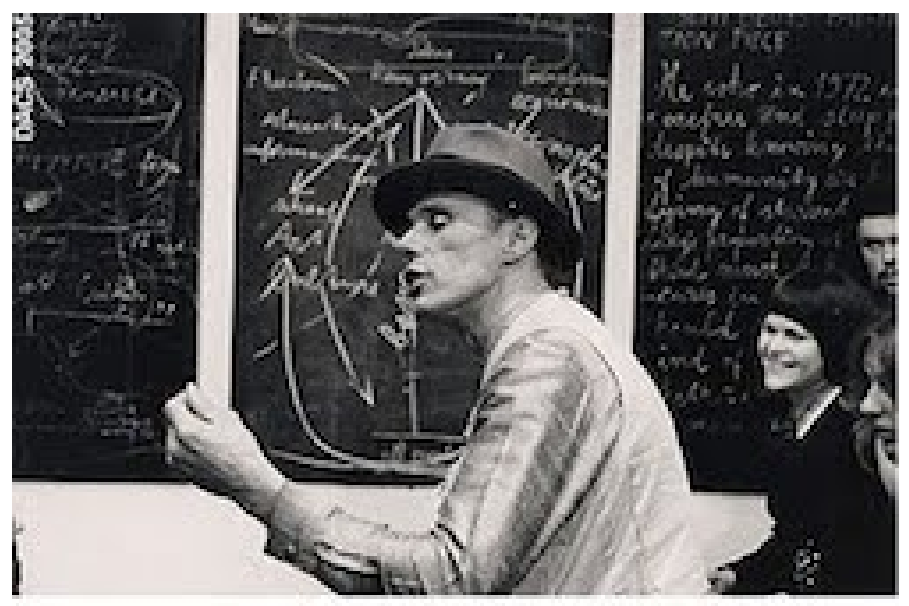

Figura 4: Joseph Beuys en el aula.

Estas transformaciones han operado cambios sustanciales tanto en las categorías estéticas como en los principios básicos de la enseñanza del arte, estableciendo una extraña convergencia entre el espacio propio de la enseñanza (la universidad) y el ámbito del sistema del arte; en este sentido, podemos reseñar como desde diversas instituciones culturales se han planteado recientemente el cuestionamiento de la enseñanza y la investigación artística, a través de seminarios o publicaciones, destacando, las siguientes:

- La formación del artista: investigación y capitalismo académico. Febrero, junio y octubre, 2013. Museo Reina Sofía. ${ }^{6}$

- Pensar y enseñar arte: entre la práctica y la especulación teórica, 2010 MACBA 7

- Desacuerdos $n^{0}$ 6. Sobre arte, políticas y esfera pública en el Estado español (2011) trata sobre el "giro educativo" invocado por la práctica artística, curatorial e institucional. ${ }^{8}$

6 http://tinyurl.com/qd4z8qy [Fecha de consulta: 2 de mayo de 2013] 7 http://tinyurl.com/7g3tq3g [Fecha de consulta: 2 de mayo de 2013]

8 http://tinyurl.com/7g3tq3g [Fecha de consulta: 2 de mayo de 2013] 
- documenta 12 magazines ${ }^{9}$ (2007), editadas en el Estado español, Brumaria y Zehar (números 6o y 61 bajo el título "La escuela abierta")

- Enseñar / Producir, 2005-06, organizado entre Le Fresnoy, Centre Pompidou, MECAD y ZKM trata sobre la enseñanza del media art y la producción. ${ }^{10}$

- (a-S) arte y saber, 2004. Arteleku-Diputación Foral de Gipuzkoa con la colaboración de UNIA. ${ }^{11}$

Cualquiera de estos eventos ofrece un cuerpo de estudio y reflexión propio para la elaboración de una investigación, a los que podríamos sumar congresos, publicaciones periódicas o plataformas online que tratan también entorno a estos problemas, sin embargo nuestro esfuerzo se concentra en la generación de un espacio de reflexión propio, que reconoce los vínculos con el ámbito artístico pero plantea un enfoque novedoso respecto a las líneas y métodos que a nivel académico en el contexto de la universidad, en el área de Bellas Artes ${ }^{12}$, de momento se han planteado; es por ello, que pensamos en la elaboración de esta propuesta de metodología que llamamos elementos discursivos.

9 http://www.documenta12.de/magazine_es.html [Fecha de consulta: 2 de mayo de 2013]

10 http://tinyurl.com/pmoy6pp [Fecha de consulta: 2 de mayo de 2013]

11 ver http://tinyurl.com/ozerdgx [Fecha de consulta: 2 de mayo de 2013]

12 Destacamos las siguientes Tesis Doctorales que en cierto modo, se han aproximado a las cuestiones que tratamos:

Sainza Fraga, Bárbara (2013) La creación, la producción, los procesos y las prácticas artísticas contemporáneas. Dirigida por Josu Larrañaga Altuna. UCM

Hernández Revuelta, Ana (2012) El papel del arte en la adquisición de competencia para el modelo de enseñanza-aprendizaje del Espacio Europeo de Educación Superior (EEES). Dirigida por Josu Larrañaga Altuna. UCM

Perezzan Pardo, Gabriel (2009) Del análisis multidisciplinar de los procesos de creación a una pedagogía del arte como propuesta metodológica para una construcción crítica de la realidad. Dirigida por Ana Navarrete Tudela. UCLM

Boj Tovar, Clara (2004) Transversalia.net. Proyecto de un entorno virtual de aprendizaje para la educación en valores a través del arte contemporáneo. Dirigida por Maribel Domènech Ibáñez. UPV. 


\subsubsection{Pensar los limites.}

Pensar los límites implica conocer las condiciones de posibilidad ¿Existen límites en una investigación académica? ¿Cuáles serían, para una tesis del área de Humanidades y de Bellas Artes, concretamente? ¿Qué formatos son reconocidos? ¿Es posible abordar problemáticas relativas al binomio enseñanza artística-universidad entrelazadas con las contradicciones propias del mundo del arte?

"Una sociedad asimila las "transgresiones" del artista en tanto su obra ha hecho saber. Por eso la obra de arte, antes que un objeto de conocimiento, es un objeto de saber: objeto de saber en tanto se da a saber -como objeto-, y en tanto promueve el saber en el sujeto -como acto-." 13

Una de las cuestiones fundamentales en esta investigación es la definición del marco y los conceptos que, en relación a la propuesta metodológica o didáctica, utilizaremos. De momento, intentaremos alejarnos de la connotación de definición (de lo que sea) como descripción, para así centrarnos en la operacionalidad técnica que se refiere a signos, y en la operación misma de introducir formalmente los conceptos y términos que manejaremos en el sistema de signos propio (como el lenguaje, sus teorías) de los modos de prácticas artísticas actuales.

En todo caso, es conveniente que quien utilice o se acerque a nuestra propuesta metodológica, comparta el enfoque, el punto de vista o la misma definición, claridad y, si es posible, interpretación de las formulaciones conceptuales que ponemos en juego. En ese sentido entiéndase como misma la relación escritura-significado, entiéndase entonces como especificidad de significación en el sistema de signos que hemos elegido y no en otro. Nótese así mismo que fuera de este contexto operacional el conjunto de las definiciones que expondremos pueden quedar desprovistas de la eficacia connotativa y de la significación que éste inicial contexto de algún modo le confiere.

Difícil es, pero no imposible de imaginar, el hecho de que tenga lugar 
alguna vez la situación ideal. De ser así, todo, absolutamente todo, orbitaría en el mismo anillo y sobre el mismo núcleo específico de atención: o sea, la detección creativa del conjunto de los elementos discursivos iniciales (EDI) determinantes en la trayectoria inmediata y puesta a punto de la idea de obra. Ahora bien, ¿de qué modo es posible conformar la especificidad no sólo del conjunto de los elementos discursivos iniciales sino también el marco panorámico que los acoge?

Tal vez, a la propia complejidad que acusa el conformado general del marco y de los conceptos necesarios, habría que oponer, entonces como una estrategia conveniente, la propia naturaleza desplazatoria ${ }^{14}$ y cooperativa de los conceptos como tal. Esto es: el concepto debe cumplir, además de sus funciones semánticas intrínsecas y heredadas, las funciones que como novedad se les asigne desde el nuevo contexto de funcionalidad y en relación con su capacidad de acogimiento cooperativo que dicho contexto como tal potencialice; o sea, respecto a todo aquello que vuelve estable y redirecciona la semanticidad absorbida por el concepto.

Dentro de este marco señalaremos los siguientes nodos: Los elementos discursivos, entendidos como los condicionantes mínimos desde los que es posible iniciar la articulación de la idea de proyecto de obra, cuya localización ha de buscarse en relación con el lenguaje como mediación. Sin embargo, esa localización, ese principio direccional de los elementos discursivos sigue necesariamente un mínimo orden que llamamos oracional (u ordenaciones oracionales) y que describe y contempla, como cualquier estructura escritural básica de naturaleza sintáctica, la expresión de un pensamiento completo, y, por lo mismo, si no un significado por lo menos una intencionalidad significante.

"En el tema de la escuela, el gran problema de muchos profesores es que, sabiendo qué hacer, no saben responder a la pregunta: ¿yo quien soy? En estos momentos, el principal desafío de las prácticas

14 BAL, MIEKE, Íbidem. 
pedagógicas o educativas sería contestar a esto, y sobre todo a su corolario, que es el de quién puedo ser; el deseo de querer ser."15

Deberíamos, entonces, tomar en consideración la distinción entre lo educativo y lo pedagógico, lo artístico y lo institucional, controversias de un entramado complejo que parte de la experiencia de hacer y que intercambia o simultánea las tareas de distintos papeles, entre artista, profesor, espectador, crítico, pedagogo; el devenir de estas líneas nos ha permitido delimitar cual ha sido nuestro marco de acción de cara a definir con precisión lo que nuestra propuesta puede ofrecer. En este sentido, entendemos la estrategia propuesta como un modo o práctica de campo que nos ha obligado a rastrear, a probar los elementos discursivos a través de distintos proyectos artísticos, en distintos contextos, con la intención de reflexionar, a través de la escritura y con el objetivo de producir un texto crítico.

\subsubsection{Condiciones del problema.}

El cuerpo explicativo del principio "elementos discursivos", que nuestro sistema pone en juego como herramienta para el análisis y el conformado de la idea de obra, en tanto que objeto de estudio, si así puede decirse, de premisa teórica relevante para la optimización de la idea, y, si admitimos, que idea y obra constituyen la misma cosa, esto es, que la naturaleza de la idea de obra garantiza ciento por ciento la naturaleza de la obra misma o de la obra en sí, entonces deberíamos admitir la importancia de la organización de la premisa argumentativa orientada hacia el conformado de la conclusión obra.

Es esa no especificidad la que marca, instaura o potencia, el cuerpo mismo de nuestra metodología, y lo hace en tanto que apunta a la consideración de lo probable, de la opinión, de lo posible y de la remisión constante a las múltiples caras o variables de un mimo asunto

15 HERNÁNDEZ, F., en "El giro educativo en el Estado español", publicado en Desacuerdos 6. Sobre arte, políticas y esfera pública en el Estado español. Ed: Arteleku-Diputación Foral de Gipuzkoa, Centro José Guerrero-Diputación de Granada, MACBA, MNCARS y UNIA arteypensamiento, 2011. Pág. 288. 
o cuestión, como rasero estratégico, experiencial y de observación, según la cuestión abordada, según la experiencia de partida. Es por tanto, aquello que marca nuestra metodología, la fuerza técnica de la reflexión sobre la experiencia artística aplicada al saber y por tanto a esa cierta voluntad argumentativa que necesariamente abandona el deseo con tal de redundar en una base metodológica.

El arte, de tener un contenido específico, éste debería ser el arte mismo. Sin embargo, como de esa especificidad carece, su especificidad lógica ha de pensarse como una no especificidad; o sea, algo así como un centro - no-centro, o, un centro descentrado.

"La pretensión de crear las condiciones de posibilidad para afirmar no ya una "epistemología del arte", sino más bien un "saber" artístico, apunta al intento de situar el campo del arte más allá de su condición de objeto de estudio, tal y como ha sido tomado por disciplinas diversas (historia del arte, sociología del arte, filosofía del arte, psicología del arte, antropología del arte, etc...). La pretensión responde a una experiencia artística que no queda en propiedad suficientemente explicada o conceptualizada por cada una de esas disciplinas ni por su conjunto; y a una exigencia artística de autoconsciencia o autoreferencialidad cognitiva que va más allá del simple ensimismamiento temático o retórico al que nos habituaron las vanguardias." 16

Nuestra metodología pretende ser herramienta no de manualidad sino herramienta de crítica, que tal vez se apresure, a través de una cierta recuperación retórica, a llenar de incertidumbre todo aquello que no siéndolo, es entendido, admitido y, en todo caso, impuesto como resoluto y determinante por ser de algún modo o por haber aparentemente devenido de la lógica formativa de algunos modelos o prácticas próximas a los ámbitos disciplinares que de cierta manera piensan el arte.

16 MORAZA, JUAN Luis. (A+S) arte y saber. Ed. Arteleku, 2003. Pág. 3 
"Mientras que el arte mismo supuestamente genera conocimientos, o los organiza en una forma hasta el momento desconocida, la enseñanza del arte se limita a repetir."17

El arte, y éste es uno de los pilares de nuestra metodología, los modos de prácticas y formas sensibles de hacer que a él son afines, las obras y sus procesos formativos, guardan una visible correlación, aunque eso no quiere decir, porque no lo afirma, que constituyan lo mismo ni que tengan un lugar específico en el mismo ámbito en el que se les relaciona.

En ese sentido nuestra metodología distingue tres términos iniciales para su uso o adecuación operativa, que son: Paisaje, Entorno y Contexto base. Esta distinción inicial es fundamental porque censura la siempre inaugural confusión respecto al dominio y objeto de la acción didáctica misma en relación a la complejidad de lo universal de la cuestión arte, a la vez que nos ayuda en la distribución de los capítulos de la tesis.

Lo interesante de esta distinción de tres términos, conceptos o categorías iniciales, es que desde el inicio mismo nos dejan ver que ninguno de ellos desbordaría al otro, lo que quiere decir, que siendo abordados desde sus propias y especificas complejidades cada uno satisfaría su natural (por propia) potencia de objetivación crítica y por tanto colmarían sus fuerzas de autocrítica, o lo que es lo mismo, la proyección, en términos del volúmenes o de cauces, de sus valores de socialización, de saberse y de entenderse entonces unos siempre saludables estados de socialidad.

En el Capítulo II, abordaremos el Paisaje Teórico que define el foco de la investigación, definición de paisaje (para/desde el arte) en el sentido propuesto por Jordi Claramonte:

"Un paisaje -lo hemos explicado ya en alguna otra ocasión- no es sino una matriz de conflictos posibles. Con ello queremos decir que no se limita a ser un simple recipiente, un contexto que acompaña discreto y displicente. Un paisaje es siempre productivo, cuanto menos de las condiciones de posibilidad de los sistemas prácticos que lo habitan y que al hacerlo son capaces de modificarlo. De este modo,

17 CAMnitzer, Luis. "Codificar y decodificar", texto escrito en 1971 y publicado en Arte y Enseñanza: la ética del poder. Ed. Casa de America, 2000. Pág. 32. 
al cambiarlo, modifican el equilibrio mismo, el ecosistema relacional en que habian hallado un nicho. En función de esas modificaciones cabe esperar que haya sistemas prácticos que resulten expulsados mientras que otros se refuerzan o mutan." 18

El paisaje teórico, donde situamos nuestra investigación, parte del Proyecto de inserción sociocultural "Proyecto Nada", desarrollado en los ochenta en Santiago de Cuba; a través del cuestionamiento de los procesos de legitimación institucional de las prácticas culturales planteamos la cuestión/relación entre práctica artística-universidad.

El Capítulo III esta dedicado al Cuadro Didáctico que acoge la reflexión sobre los elementos discursivos, y para enmarcar su campo de actuación se ha hecho preciso establecer un posicionamiento entorno a la metodología y didáctica, sirviéndonos en su desarrollo de la elaboración de múltiples diagramas ${ }^{19}$ que nos ayuden a visualizar la propuesta metodológica de los elementos discursivos. El diagrama, según lo define Deleuze, "no funciona para representar, ni siquiera algo real, sino que construye un real-futuro." 20 En este sentido, el de un real-futuro, hemos estructurado y planteamos a modo de conclusiones el capitulo IV.

Completa el volumen de la memoria de tesis, la recopilación en dos apéndices diferenciados, el primero de ellos, el Apéndice I, recopila (cronológicamente) los textos realizados durante un largo periodo que comprende desde 1988 a 2012. Los resultados esperados por tanto son -han sido- textos que en el tiempo se han publicando en distintos medios de comunicación (online, offline, catálogos) atendiendo

18 ClARAMONTE, JORDI. "Edades del monstruo" publicado en http://tinyurl.com/q6mkb92 [Fecha de consulta: 4 de diciembre de 2011]

19 "El diagrama, terminología tomada de la filosofía kantiana, será el modelo abierto que cada artista-creador erige como paradigma a alcanzar. Pero debe comprenderse cómo este modelo no es para nada actual o cerrado, y no es susceptible de copia según el esquema representativo. El diagrama es, en este sentido, el sentido mismo del rizoma en tanto que condición de posibilidad de la creación de lo nuevo y que no tiene por qué tener relación de semejanza alguna con lo creado." León Casero, Jorge, "Gilles Deleuze", en Fernández Labastida, Francisco - Mercado, Juan Andrés (editores), Philosophica: Enciclopedia filosófica on line, URL: http:/ / tinyurl.com/nfujf8z [Fecha de consulta: 10 de mayo de 2013]

20 Deleuze, Gilles y guattari, fÉlix. Mil mesetas. Capitalismo y esquizofrenia, Ed. Pre-Textos, Valencia 2004. Pág. 75. 
a distintas estrategias y necesidades, y que ahora, por primera vez se recogen conjuntamente. Es por ello que se ordenan los textos siguiendo la cronología de la escritura, uno tras otro, como bloques que construyen un corpus teórico, atendiendo las transformaciones e intereses suscitados según los distintos contextos de producción, producción artística dirigida a promover la reflexión y el discurso entorno al arte contemporáneo y su investigación en el ámbito universitario.

El segundo Apéndice, las vídeo-entrevistas publicadas en la plataforma www.nonsite.es, realizadas en 2009 sobre el contexto del arte y concretamente, sobre el concepto de crítica, agrupadas bajo el epígrafe de "Dossier de crítica". El sentido de ir relacionando la reflexión sobre la obra de arte, la enseñanza del arte, pedagogía del arte responde como han coincidido numerosos artistas y profesores a que la enseñanza del arte es consustancial a la producción el arte, como menciona Joseph Kosuth:

"En mi opinión, la enseñanza del arte es una parte importante de la producción de arte. En muchos sentidos es el "tableau" donde la sociedad, en términos prácticos, hace visibles los límites de su concepción del arte en un intento de regenerar las formas institucionales que representan su auto-concepción. Cuando nuestra visión del arte es limitada, también lo es nuestra visión de la sociedad. Si las preguntas no se hacen en las escuelas de arte, lejos del conservador candelero del mercado del arte, ¿dónde pues? El profesor de arte, como profesor y como artista, no puede hacer más que participar con los estudiantes en hacer preguntas. El profesor no es el representante de la institución, sino un artista entre otros compartiendo una conversación. Lo que se dice tiene su propio peso. Si un profesor es bueno aprende tanto como los estudiantes. Las "respuestas", si las hay, surgen de todos los participantes en la conversación dentro del contexto de sus propias vidas, y sus efectos 
prácticos ocurren sólo dentro de ese gran proceso conversacional que es el discurso compartido de una comunidad." 21

21 Joseph Kosuth: "Teaching to learn" publicado en Art After Philosophy and After: Collected Writing, 1966-199o. Ed. The MIT Press, Cambridge y London, 2002. 
Parte II

PAISAJE TEÓRICO 



\section{PAISAJE TEÓRICO}

"Un paisaje -lo hemos explicado ya en alguna otra ocasión- no es sino una matriz de conflictos posibles. Con ello queremos decir que no se limita a ser un simple recipiente, un contexto que acompaña discreto y displicente. Un paisaje es siempre productivo, cuanto menos de las condiciones de posibilidad de los sistemas prácticos que lo habitan y que al hacerlo son capaces de modificarlo. De este modo, al cambiarlo, modifican el equilibrio mismo, el ecosistema relacional en que habian hallado un nicho. En función de esas modificaciones cabe esperar que haya sistemas prácticos que resulten expulsados mientras que otros se refuerzan o mutan."

Jordi Claramonte 


\section{1 la teoría, por su uso, distingue lo que la práctica confunde}

El paisaje teórico en el ámbito de las prácticas de visualidad contemporánea es mucho más pobre y desalentador de lo que pensamos. Pobre en las prácticas de a diario -en el momento de su definición-, o bien, dicho esto en términos domésticos, en el momento de la puesta en juego respecto a ellas (en tanto que modos de hacer), de las hermenéuticas básicas, o si se prefiere, de la puesta en juego de esa precaria semiología (también básica), que el empeño propio de lo práctico requiere. Faltan a raudales -más que otras cosas-, esas formulaciones individuales que hurgan en los nodos de conexiones primarias -ya no en ese plano especulativo dado a los humanos-, sino en la práctica tal cual, sobre ese "con qué funciona [el libro]» ${ }^{1}$ o lo que sea, en conexión con el algo que se tiene entre manos: con qué aquella otra intensidad no visible a nuestro modo de percepción y de acción, no sólo guarda conexión, eso que tenemos dado en nuestras manos, sino en qué aquella otra multiplicidad pretendemos introducirla, y, en la mejor de las aventuras, darle o visualizar su conexión. Ciertamente, la cuota teórica básica que a todo modo de práctica en teoría se la supone, parecen estar bajo mínimos.

El paisaje teórico de los modelos prácticos que contemplamos se presuponen a sí mismos caídos en la trampa de las [búsquedas de] significaciones últimas, de abordajes temáticos y mainstraim ${ }^{2}$, más no en conexión o como los nodos constatativos de sus derivas e interconexiones con otras tantas multiplicidades, intensidades y tensiones. Los despropósitos históricos de las prácticas próximas o relativas al arte, fundados muchos en las aspiraciones (también anteriores) y fines propios de la modernidad -la mayoría de edad del individuo que ejerce su razón de forma autónoma ${ }^{3}$, el mundo de metas,

I Deleuze, Gilles y fÉlix guATtARI: Mil Mesetas. Capitalismo y esquizofrenia [1980]. Valencia: Pre-Textos, 1994. Pág. 10.

2 MARTEl, FrÉdéric. Cultura Mainstraim: Cómo nacen las fenómenos de masas. Ed. Taurus. Madrid, 2011.

3 Desde el punto de vista filosófico el concepto de Modernidad es similar al concepto de Ilustración kantiano: En el ámbito de modernidad cada ciudadano de forma 
de regulación de la reproducción social, de la transformación del sentido temporal de la legitimidad o del reemplazamiento del pasado por el porvenir-, hoy constituyen una vasta acumulación heredada (también de despropósitos y anacronismos), de teorizaciones e intromisiones, como por ejemplo: el anuncio profético y de anticipación (responder mediante hipótesis) a base de los artificios y técnicas de la duda y de la carencia, propio del discurso de las vanguardias; el esfuerzo, implícito o explícito, del arte por mantener alejada y a raya la fuga del tiempo «para resguardarse de la entropía de toda forma de viviente» 4 en cuyo fondo asoma el señalamiento de los moralistas renacentistas de «que el nacido es suficientemente viejo como para poder morir»; la vieja creencia del fomento de una autonomía personal a través del arte o de que éste por sí mismo la fomenta, criticada por Leonel Trilling 5 y puesta en entredicho por la fascinante conjunción del arte popular y el comercial con el llamado arte avanzado o "elevado» ${ }^{6}$; axiomas casi todos, propios de la esperanza razonable del liberalismo cultural y de positivismo científico del siglo XIX, que han sido probados como falsos aunque, eso si, como expresiones disciplinares permanecen en el inconsciente práctico y de los modos de hacer contemporáneos, ya no sólo como falsaciones de la consistencia de las nociones de valor y de significado que en torno a los modos de práctica actuales manejamos, sino en su inacabamiento (en el sentido, también negativo, son potenciadores constante de los nuevos oscurantismos artísticos, las nuevas maneras reaccionarias de su proyección y de las formas de su enclasamiento) en tanto que constitución de problemas que jamás han sido resueltos.

lógica y racional propone sus metas y fines según su propia voluntad con los que sistemáticamente ha de dar sentido a (su) la vida, del mismo modo que el individuo ejerce de forma autónoma su razón.

4 Steiner, George. Gramática de la creación. Ediciones Siruela, 2011. Pág. 12

5 TRILling, LeONel. Sincerity and Authenticity. Cambridge, MA, Harvard University Press, 1972, pág. 27.

6 Para Donald Kuspit, (El fin del arte, 2006, pág. 12) “emplear el término «arte avanzado" hoy en día es sugerir un fenómeno elitista, exclusivo, inaccesible, de indole diferente a la de los fenómenos cotidianos, y como tal algo que se privilegia a sí mismo y no tienen que ver con la vida cotidiana, la cual ha de sobrevivirle $y$, si se puede, florecer en él, aparte de que es inherentemente trágica por el simple motivo de que es cotidiana [...] Si falta lo vulgar, falta lo que parece más humano." 
En 1934 John Dewey en su magnifico libro Art as expericnce ${ }^{7}$, advierte a través de lo que él llama "irónicas perversidades" sobre el problema de la disociación entre el entorno de teorización de la obra y su entorno de producción, y de las consecuencias de esa disociación no sólo en el plano valorativo de las propias producciones artísticas, sino sobre todo en el plano formativo. Advierte de algún modo sobre la pérdida de la conciencia de conexión formativa de la cosa obra con un entorno específico de formulación, y de la posibilidad de su corrección. Lo cierto es que sus advertencias y teorizaciones, sobre todo, en el ámbito de la enseñanza del arte y de sus modos de práctica, para nada han sido ni leídas ni tenidas en cuenta, de manera que hoy nos encontramos prácticamente con un panorama similar, si no desprovisto de aquellas solicitadas conexiones -con las condiciones humanas de las cuales obtienen su existencia- al menos falto de un instrumental que por extensión las canalice en el momento del aprendizaje de la propia práctica. Camnitzer ${ }^{8}$ habla literalmente de analfabetismo cuando se refiere a la armazón pedagógica adherida a la enseñanza del arte y a su desatención a la especificidad de los diversos procesos creativos y perceptivos, que deberían llevar, así mismo, a grados más elevados y productivos el propio modelo de enseñanza. Como Camnitzer, aunque mucho antes, también Pierre Francastel parecía insinuar la idea de una cierta crisis escópica [de conocimiento y de reconocimiento extensible, por tanto, también a los modelos de enseñanza y a su relación metodológica con el arte] que se extendería en el tiempo, precisamente en el momento fundacional de su sociología del arte. Por un lado, hace una dura crítica a la posición de la sociología de entonces (a su método y a su entorno, cuya base problemática parecía haberla cimentado) en su introducción a Sociología del Arte:

"El número de trabajos donde simplemente se admita la posibilidad de un estudio relativo a las condiciones en las cuales se crea

7 DEWEY, J., El arte como experiencia. Ediciones Paidós, 2008. Traducción y prólogo de Jordi Claramonte.

8 camnitzer, Luis. Arte y Enseñanza: la Ética del Poder. Colección Apuntes. Ed. Casa de América. 2000. Madrid. Pág. 15 - 18. 
realmente la obra de arte es ínfimo. La obra, monumento, escultura o pintura, es considerada como un objeto que posee los caracteres generales de todos los objetos naturales. Todo ocurre como si una fuerza misteriosa, análoga a la de un individuo, interviniera en épocas determinadas para poblar el ámbito de los hombres de un cierto número de hitos destinados a servir de sostén a tales especulaciones... La práctica corriente de la actual sociología del arte descansa sobre la idea de que cualquiera de nosotros es capaz de comprender e interpretar inmediatamente -incluso producircualquier obra de arte.

La idea de que esta obra de arte pueda tener un significación propia, irreductible a cualquier otra, no asoma, en general, en el pensamiento de los sociólogos. La obra de arte no sólo aparece en el campo de la experiencia humana como un dato fundamental unido a la existencia de un tipo de objetos de la creación, sino que además -como la mayoría de los objetos naturales- postula que todo hombre posee la facultad de captarla e integrarla en su experiencia personal, sin recurrir a ninguna técnica particular de comprensión."9

Y por otro, articula la base de su metodología de análisis:

"El problema planteado por el desarrollo de una disciplina humana moderna, como podría ser una autentica sociología del arte, no se presenta como un método determinado de clasificación de los conocimientos sin reabrir la discusión sobre la naturaleza misma del objeto considerado."

No hay duda de que aún la perspectiva de análisis, de proyección y de contribución del arte se mide - tal vez sería mejor decir se clasifica, aunque también podría introducirse aquí la reflexión sobre la cuestión de si los conceptos y procedimientos de la tradición crítica son anticuados o no- "de acuerdo a sus productos finales: cuadros,

9 FRANCASTEL, PIERRE. Sociología del arte. Alianza Editorial Madrid. 1984. En Introducción. Para una sociología del arte: ¿Método o problemática? Pág. 7-9 
obras de teatro, sinfonías o lo que sea"10. Los esfuerzos clasificatorios continúan y el inventario de síntomas superficiales para el análisis de la acción contributiva del arte sigue creciendo por la simple razón (aunque, esta noción de lo simple debería ser entonces pensada en un mar de configuraciones extremadamente complejo y asediado por la irracionalidad y los oscurantismos de quienes de algún modo lo gestionan) de que en la constitución misma del síntoma, o del conjunto de ellos, no entra en juego, para nada, la consideración de los procesos creativos o modos perceptivos que de algún modo sirven de vehículos formativos de los productos artísticos finales.

Ya, desde el inicio mismo, podríamos formular una primera sospecha respecto al papel de contención que dichos modos de clasificación juegan en las estrategias de planificación de los modelos de enseñanza del arte, por un lado, y por otro, el papel de distanciamiento real en relación a la posibilidad de contribuir al diseño de planes de estudios generales que influyan directamente, por ejemplo, en la enseñanza de otros campos de producción o en la enseñanza de la ciencia, o de la filosofía. Dicha sospecha tiene que ver con algo que llamamos "intento de anticipación de la representación de la cosa" que luego abordaremos, aunque desde ya acentuamos que deduce no sólo una cierta ansiedad en torno a la cuestión formativa de las cosas mismas [la cosa parece que siempre lo ha sido, sin proceso alguno], sino algo, en su caso, que oscila perversamente entre los márgenes del analfabetismo disciplinar y el de la fantasía del poder: la cosa debe seguir pareciendo que siempre lo ha sido [así y tal cual] o, en el peor de los casos, su radio de acción reflexiva o de zona de influencia crítica, ha de permanecer al margen del modo mismo de su clasificación. También podríamos formular una segunda, y no menos importante, sospecha que apunta a la permanencia del arte (nos referimos a los tratamientos y procesos de aproximación respecto a su dominio en el ámbito universitario) a niveles de actividad dedicada a satisfacer el ocio o de complemento en relación a la especificidad de los otros campos de producción o campos generadores de valor. Sin

10 CAMnitzer, Luis. “Codificar y decodificar (1971)" en Arte y enseñanza: La estética del poder. Colección apuntes de CASA DE AMÉRICA. Madrid, 200o. Pág. 15. 
embargo, estas dos sospechas iniciales no deberían disparar las alarmas, puesto que el problema del arte no es un problema general, digamos esto de una vez, pero para ello pondremos un acento también camnitzeriano:

"... hay premisas (premisas pre-estéticas) que son útiles y comunes
para cualquier campo de estudio. Después de todo, los individuos
y las sociedades se expresan en todos los campos disponibles. No
reducen su expresión a lo que pueden encontrar en el pequeño
estante reservado al arte."11

En ese sentido, la aspiración de que tanto los individuos como las sociedades se expresen [en común] en el reducto del arte es, sin duda, parte y proyección de la fantasía del poder: es por ello, en tanto que diseño de andadura y gestión de los límites del poder, un modelo de clasificación y un modelo de gestión disciplinar. Es aquí, en este punto del recorrido, donde toma cuerpo nuestra tercera sospecha, a saber: los modelos y configuraciones actuales de la enseñanza del arte albergan en su fondo profundo un, más que perverso pervertido, espíritu burgués cuyo latido se proyecta, y no de otra manera, como amenaza de fragmentación contrapuesta al incremento de las capacidades de obrar y comprender que se desprenden del desarrollo autónomo de otra sensibilidad o facultad de enseñanza, ya no sólo del arte, sino también, del desarrollo autónomo de otras formaciones de enseñanza en general. La formación inicial de ese espíritu burgués o amenaza de fragmentación la vemos ligada a la negación del conjunto de premisas pre-éstéticas que dan carácter común a todos los campos de estudios permitiendo de ese modo que todos los individuos y sociedades se expresen en todos ellos y no sólo en el campo del arte. No es cierto, puesto que fundamentos no hay, ese carácter absoluto de la idea de la necesidad del arte, es más razonable pensar en la necesidad de expresión en tanto que no sólo es común a todos los campos de estudio sino que es más bien a través de todos ellos que vehiculizamos nuestras expresiones de sociabilidad.

11 Íbidem, pág. 16 
Nuestro trabajo toma en algunos de sus tramos ese presupuesto camnitzeriano para, en todo caso, introducir un conjunto de reflexiones y juegos categoriales ordenados bajo el principio metodológico que denominamos de detección de los elementos discursivos del que en el transcurso de la investigación haremos mención a través de la sigla 'MDDED' ${ }^{\prime 2}$. Nuestra investigación plantea un problema de denominación pues los términos que dieron pie a ella tienen un carácter si no inédito al menos provocador. Para empezar tomaremos algunos riesgos o decisiones terminológicas. Por ejemplo, agruparemos bajo el término elementos discursivos todo lo que tenga que ver con ciertas gramáticas o figuras gramaticales asociadas a la configuración de la idea de obra o, en su caso, al tramo constitutivo de la idea de idea de proyecto de obra; y bajo el término experiencia de relacionar, el acento constante y la atención que el sujeto (espectador o artista) pone ante cada parte o ámbito de cosa, puesta en relación.

12 La MDDED es en conjunto el sistema metodológico abierto que nos permite a partir de la elección una o varias de cosas, las que sea, disponer de ellas como operacionales y extraer de su realidad los elementos (esenciales, connotativos, significantes, etc.) que deducen la naturaleza y tipo de operación artística que puede o no llevarse acabo, si se les toma como referencias. 


\subsection{FOCO DE LA INVESTIGACIÓN}

EXPERIENCIA DE RELACIONAR: DE LOS ELEMENTOS DISCURSIVOS A LA FORMULACIÓN DE LA IDEA, primero como proyecto de investigación y ahora como argumentación de ésta tesis, toma como punto de partida el conjunto de conceptos y de categorías que, en su momento, manejamos en el «Proyecto Nada» ${ }^{13}$.

La concepción y naturaleza del «Proyecto Nada» era la de un «proyecto de inserción socio-cultural» y fue realizado en la ciudad de Santiago de Cuba en 1988. El propósito inicial consistía en articular a través de la disposición práctica un mecanismo-alarma que diera cuentas (en forma de llamada de atención, de toque cívico o de oposición), respecto a todo un sector de la vida socio-politica local -en su caso, comisarios, críticos de arte, historiadores del arte, funcionarios de la cultura y la politica, directores de museos y galerías de arte- encargados de ejercer la función crítica y el análisis (y de ser oportuno y necesario, la censura) sobre las diversas prácticas, pensamiento y producciones de arte contemporáneo que entonces estaban teniendo lugar; dicho propósito debería ser cumplimentado mediante la introducción y gestión de una serie de prácticas-problemas, cuyos fundamentos y estrategias discursivas se anclaban rigurosamente en el arte contemporáneo y sus diversas direcciones teóricas, de tal modo que posibilitaran el afloramiento público y mediático del conjunto de problemáticas que por entonces, desde el punto de vista teórico, nos parecían absolutamente intolerables y que sólo a través de su introducción en el debate político-cultural era

13 Los proyectos de insercion socio-cultural tiene su origen en el modelo de práctica artística desarrollado por Abdel Hernández (investigador, artista y crítico de arte) a finales de los años 8o, en Cuba, a partir de la performance como base ("El juego de pelota" [béisbol], protagonizado por artistas críticos y estudiantes del Instituto Superior de Arte (ISA), "Proyecto Pilón", etc., concilia, por un lado, el interés y presupuestos teóricos de las prácticas visuales, el modelo Joseph Beuys de la relación arte-vida, las influencias y análisis heterotópicos de Juan Acha, sobre el papel de la comunidades periféricas en las prácticas y producciones culturales y estéticas, o las del modelo sensible de Néstor García Canclini para el análisis de las comunidades desplazadas, deprimidas. Sobre esas premisas tuvo lugar una diversidad de proyectos en el ámbito de las prácticas visuales en los años 8o, en todo Cuba, como el «Proyecto Nada», «Proyecto La Campana». 
posible denunciarlos; a través de preguntas del tipo ${ }^{14}$ ¿Qué uso dar al pensamiento de un grupo de intelectuales cuya práctica y universo artístico es resultado de la propia articulación programática, y la utopía, de la revolución y a lo que en gran medida intentaban dar respuesta?, o ¿A qué modelo de eficacia obedecian las expectativas y los juicios de entonces, en materia de Arte y de política del Arte? o también, la pregunta al estilo de ¿En el acuerdo de que ese modelo de eficacia y expectativa estuviera resuelto, a qué época operacional pertenecía dicho modelo?

En todo caso, es en la necesidad de invención, en la eficacia para la construcción, nombramiento y gestión de las herramientas para la producción y optimización del diálogo -en aquel entorno y en relación a aquel específico sector de la vida socio-politica local (hablamos de Santiago de Cuba, en Cuba, y, específicamente, del año 1988)- donde se produce la conexión con este trabajo.

"La activación del dispositivo promocional de la puesta en público de la obra es también parte de la obra misma. Tras una larga, intensa y entusiasta semana de promoción boca a boca y de entrega de invitaciones, de anuncios en el periódico local y en la radio de más audiencia, en los suplementos culturales de la ciudad y de la pegada de los carteles publicitarios del proyecto, todo estaba listo para que aquella noche, en el simulacro de apertura -entonces, en el estrecho vestíbulo del edificio sede de la compañía Cabildo Teatral de Santiago, unos años antes devenido en galería de exposiciones-, y por lo tanto, en los términos, maneras y convenciones de la visualidad expositiva, con respecto al «Proyecto Nada» no sucediera absolutamente nada: a oscuras la estrecha galería se iba llenando de gentes curiosas y a la expectativa de las novedades que, en cuanto al carácter y a los poderes subversivos de las obras y en última instancia del arte, supuestamente alli mostraríamos; sin embargo,

14 Es interesante la idea de aislar unas ciertas palabras con fines metodológicos, como por ejemplo Arte y Artista, con tal de entender y evaluar el conocimiento formulado en torno a ellas; a decir, los juicios existenciales y de valor, los presupuestos ontológicos y epistemológicos, principios teóricos, procedimentales y técnicos de cada modo de hacer o de práctica particular. 
allí no ocurrió nada. La experiencia desarrollada en la Galería del Cabildo durante el mes, en términos metodológicos, trató de establecer una clara distinción entre los elementos discursivos de una propuesta crítica respecto al contexto socio-cultural de Cuba y la posibilidad de construir un proyecto artístico entendido como práctica temporal donde la relación habitual obra-artista-espectadorcrítico debería verse desplazada por la convergencia de la figura "espectador-obra" que sería la encargada de potenciar la repercusión de lo acontecido en el sistema crítico institucional."15

El «Proyecto Nada», como base de nuestra investigación, ahora profundizada, traza un primer rumbo -o la base simplificada de su arquitectura e intimidad, tal vez su caracterización metodológica-, sobre las posibilidades esencialmente teóricas (aunque a la vez, si bien como testimonialidad, su proyección potencialmente operativa), de aproximación a las zonas límites de la formulación, la configuración, el proceso y el análisis de la idea de obra.

A largo de la historia -sobre todo de la historia reciente-, los conceptos "arte" y "obra de arte"16 han sido distinguidos, utilizados en distintos ámbitos y en incontables ocasiones, de forma dispersa, abusiva y errónea; a veces han sido utilizados de forma alarmantemente insultante, de tal manera, que sus viajes de ida y venidas -halonazos, puede decirse, si se quiere-, en muy contadas ocasiones nos justifican su verdadera dimensión y prestancia. En ese sentido el uso que daremos a ambos conceptos (y a otros agrupados bajo el epíteto de conceptos fuertes) será extremadamente cuidadoso. Aparecerán, eso sí, en muchas ocasiones y zonas dispares de nuestra argumentación pero siempre garantizando su prestancia más amplia. Se tratará, con su uso y optimización $-\mathrm{y}$ puesto que la propia interacción con dichos conceptos abriría paso

15 Texto sobre el "Proyecto Nada" publicado en la Revista Arte: Proyectos e Ideas. Ed. Laboratorio de Luz, Universidad Politécnica de Valencia. $1993 \mathrm{~N}^{\circ} 1$.

16 Éste último alberga una dualidad extremadamente problemática: por un lado, la cuestión de la obra y aquello que la delimita, enclasa, etc.; y por el otro, la cuestión del arte (en cuanto qué es o cómo se la define) y por extensión el problema ontológico de su naturaleza. 
a esa posibilidad-, de favorecer el acercamiento a la construcción de relaciones ampliada de criticidad: por lo mismo, a una escritura que necesariamente ha de ser crítica y necesariamente ha de ser criticada; por tanto a una esfuerzo de escrituralidad.

Es precisamente la dirección y el entusiasmo apuntado anteriormente lo que sitúa al «Proyecto Nada» no sólo como nuestro antecedente de historización lógica, sino en las bases convenientes de nuestra investigación y argumentación. Se trata de la misma base y de la misma voluntad conveniente en tanto que del mismo modo que investigamos y argumentamos, en ese mismo sentido hemos de ir obrando. Base y voluntad conveniente, ambas situadas en la misma tesitura y necesidad de dar una respuesta artística, y, del mismo modo, dar una respuesta crítica a aquello que consideramos como una cierta "carencia de voluntad constructiva de conceptos e imaginarios críticos», y por lo tanto "carencia de una consciencia de la posibilidad de que esto sea producido en relación a los distintos modos, poéticas y prácticas del arte contemporáneo».

Así, más adelante trataremos en relación a este asunto, pero no como asunto central, la cuestión de los abismos teóricos y el conocimiento disciplinar en relación a los modos de prácticas de a diario, que hemos detectado -que quedan configurados como una ancha y honda laguna teórico-metodológica, recluida en una suerte de meta-relato tautológico con base en la imaginería de lo local como novedad y en la incertidumbre que la figura-aspiración del genio aun parece ejercer (bajo la presión de los ismos de las vanguardias y del "yo trascendental» ${ }^{17}$ del espíritu universal de finales del siglo xVIII), como pretendida alusión directa, por un lado, a una espuria idea de lo nacional, y por otro, como una readecuación (politizada o politizante) de la idea de nación en correspondencia de la idea de universalidad: esto es, la nación es el centro en tanto la universalidad depende de su centrifugación- en el conjunto de las entidades encargadas del apoyo, la explicación y la distribución de las distintas prácticas, poéticas y modos de producción de criticidad.

El propósito que se pretende alcanzar con esta investigación no

17 KANT, IMMANuEL. Crítica a la razón pura, Taurus Ediciones, Madrid, 2005. 
podría entenderse como una meta prefijada, se trata en todo caso de un devenir, de un tránsito que atraviesa zonas -temporalesestratificadas, atendiendo principalmente a la necesidad de reflexionar sobre localizaciones que distintos elementos discursivos han fijado en textos concretos, ayudándonos a producir la construcción de un proyecto: el proyecto que por definición se establece en el espacio vacío de la expectación o el espacio de la posibilidad. ¿Por qué hablar de elementos discursivos en relación a la construcción del proyecto en arte? Sin duda porque nos remiten al sujeto que lo elabora pero sobre todo porque alude al proceso de su enunciación; el proyecto debe ser considerado como un relato-objeto que de algún modo dialoga con su contexto de producción. Las limitaciones (y supuestos) establecidos en esta investigación quedan definidos por lo que hemos determinado como puesta en práctica de una estrategia.

Delimitar cual ha sido nuestro marco de acción es igualmente necesario de cara a definir con precisión lo que se pretende hacer. En este sentido, entendemos la estrategia propuesta: «experiencia de relacionar» como un modo o práctica de campo que nos ha obligado a rastrear los elementos discursivos de distintos proyectos artísticos en distintos contextos, con la intención de reflexionar, a través de la escritura y con el objetivo de producir un texto crítico. La relevancia de la investigación y los resultados esperados por tanto son -han sidotextos que en el tiempo se han publicando en distintos medios de comunicación (online, offline, catálogos) atendiendo a distintas estrategias y necesidades, y que ahora, por primera vez se recogen conjuntamente para extraer una serie de conclusiones. Es por ello que se ordenan los textos siguiendo la cronología de la escritura, uno tras otro, como bloques que construyen un corpus teórico, atendiendo las transformaciones e intereses suscitados según los distintos contextos de producción, producción artística dirigida a promover la reflexión y el discurso entorno al arte contemporáneo y su investigación en el ámbito universitario. 


\subsection{PROYECTOS DE INSERCIÓN SOCIO-CULTURAL}

ANTECEDENTES:

Revolución - Campaña de alfabetización - Creación de la Escuelas Nacional de Arte - Escuelas provinciales de instructores de arte - Instituto Superior de Arte. Arte público*, Formas de activismo, las distintas experiencias prácticas en Cuba desde los años 50 (Grupo de los 11) y en los años 80 y 90 desarrolladas por grupos como Arte Calle, Grupo Puré, Proyecto La Campana, Proyecto Nada, etc.

Revolución: principio de distribución de "cada cual según su trabajo a cada cual según su capacidad" La utopía: forma de distribución de la riqueza de "cada cual según trabajo a cada cual según su necesidad."

Creación, mediante el decreto Ley 187 , de marzo 31 de 1959, de la Imprenta nacional de Cuba. El primer director fue el escritor Alejo Carpentier. Justo al año de creada la empresa editorial de la revolución, se realizó la edición de 100 mil ejemplares, en cuatro tomos -a precio de venta de sólo 25 centavos- del "El Ingenioso Hidalgo Don Quijote de la Mancha", del escritor español Miguel de Cervantes y Saavedra. A la publicación del Quijote le siguieron Doña Bárbara, Robinson Crusoe, Los viajes de Marco Polo y textos de otros notables autores de la literatura mundial: César Vallejo, Rubén Darío, Pablo Neruda, Nicolás Guillén, Federico García Lorca, Ernest Hemingway, Honorato de Balzac, Victor Hugo, León Tolstoi, etc. Al hilo de la creación de la Imprenta nacional de Cuba, le siguieron la creación la Editorial Universitaria, la Pedagógica, la Juvenil y la Política.

La Reforma Integral de la Enseñanza se declaró en 1959 y determinó que el objetivo primordial de la educación era el pleno desarrollo del ser humano. Se constituyó el Contingente 
de Maestros Voluntarios con 3.000 personas que partieron a educar a los campesinos que vivían en lugares remotos.

El 6 de junio de 1961 se dictó la Ley de Nacionalización de la Enseñanza que suprimió la educación privada y los viejos métodos de enseñanza y estableció una educación revolucionaria.

Campaña de alfabetización (1961): Fue una campaña de alcance nacional impulsada por el Gobierno cubano para reducir el analfabetismo e incrementar el porcentaje de población escolarizada. La campaña comenzó a prepararse en 1960 y finalizó oficialmente el 22 de diciembre de 1961, cuando el Gobierno declaró a Cuba, en la Plaza de la Revolución José Martí, como Territorio Libre de Analfabetismo. La campaña redujo el analfabetismo desde un porcentaje superior al 20 por ciento en 1958 al 3,9 por ciento en 1961. Este año, 1961, se proclamó en Cuba como "Año de la Educación".

En enero de 1961 se creó el Consejo Nacional de Cultura, actual Ministerio de Cultura de Cuba, al que se le encargó el desarrollo de una red de bibliotecas que facilitaran el acceso de la población a los libros que se habían reunido. Posteriormente, en 1962, se creó la Editorial Nacional de Cuba.

Creación de la Biblioteca del Pueblo (Biblioteca Nacional de Cuba).

Enseñanza obligatoria y gratuita hasta los 17 años. Socialización de la información: (Ser cultos para ser libres)* Socialización del conocimiento: La cultura es un derecho del pueblo* El arte como reflejo de la realidad socio-política: realismo socialista.

Idea central del proyecto educacional de la revolución: $L a$ creación del hombre nuevo: "culto, solidario, crítico."

Se instauran instituciones emblemáticas para la cultura del país como el Instituto Cubano de Arte e Industria Cinematográficos (ICAIC), creado 
apenas a 83 días del triunfo de la Revolución Cubana, lo que pone de manifiesto la preocupación del nuevo gobierno por la cultura artística. La Casa de las Américas, en abril de 1959, para desarrollar y ampliar las relaciones socioculturales con los pueblos hermanos de América.

Escuelas formadoras de maestros de Educación primaria, Columna Juvenil del centenario, Escuelas Camilo Cienfuegos (tipo militar), Escuelas de Profesores de Educación Física, Escuela de Enfermería, Escuela Nacional de Circo, Escuela de Técnicos Ferroviarios, etc.

Creación de la Escuela Nacional de Arte (1962) Convocatoria para estudios de arte a jóvenes residentes en las zonas rurales y marginales.

Un centro multidisciplinario donde se encontraran las artes y donde se produjera una interconexión activa y constante entre los estudiantes de todas las ramas artísticas.

Escuelas provinciales de instructores de arte: Creación de una red extendida de casas de culturas.

Creación de las Galerías de Arte Universal.

Alejo Carpentier gana el Premio Cervantes en 1977.

Define la idea de lo 'real maravilloso' que conformara el realismo mágico: La realidad y el sueño, la razón y la imaginación, la historia y la fábula, la vida y la muerte, lo conceptual y lo culterano. Sus novelas publicadas: AEcue-Yamba-O! (1934), El reino de este mundo (1949), Los pasos perdidos (1953), El acoso (1956), El siglo de las luces (1962), El recurso del método (1974), Concierto barroco (1974), La consagración de la primavera (1978). En 1964, ya como director de la Imprenta Nacional de Cuba, publica el ensayo "Tientos y diferencias". En 1977 tras ganar el Premio Cervantes dedica el dinero del premio a la Compra de reproducciones de alta calidad y crea en cada una de las capitales de provincia unos espacios llamados Galeras de Arte Universal.

\section{Antecedentes artístico-pedagógicos}

Creación de Instituto Superior de Arte de La Habana (1976), que introduce un nuevo concepto en la pedagogía de la enseñanza del arte. Aparecen los modelos alternativos a la enseñanza oficial del arte y por 
lo tanto al margen de todo tipo de tutela ideológica y programática: los modelos disciplinares de la enseñanza del arte basados en la tradición académica europea, son puestos en cuestión y en su lugar ensayados unos modelos dinámicos y personalizados que pretenden acelerar la conexión con la práctica y producción de discursividad real.

Uno de esos modelos fue desarrollado por Aldito Menéndez que, tras el abandono de la escuela de Bellas Artes de San Alejandro (centro de formación del hombre nuevo), sostiene la idea de que "hoy día para ser un artista no es necesaria una academia: instrucciones teóricas básicas" y se dedica a gestionar su propio modelo que deriva en la fundación del grupo "Arte Calle".

El otro modelo fue el defendido por Abdel Hernández, también exalumno de la escuela de San Alejandro, que desde sus intervenciones publicas da muestra de su rechazo frontal a la academia, dando voz y acción a su modelo de "Hacedor" o artista hacedor con el desarrollo y puesta en marcha de las prácticas de inserción socio-cultural.

Tiene lugar el primer gran proyecto de curadoría que deviene en el Proyecto Castillo de la Real Fuerza. En 1991, Juntos y Adelante! (Arte, Política y Voluntad de Representación) (ABTV), IV Bienal de La Habana, Casa del Joven Creador, La Habana. En 1989, Homenaje a Hans Haacke (AвTv), Proyecto Castillo de La Fuerza, Castillo de La Real Fuerza, La Habana. 
2.4 PRÁCTICA ARTística y UNIVERSIDAD: UNA COSA Y OTRA.

"Es en última instancia tarea del arte iluminar el lugar-el espacio de la representación- desde el que podría realizarse ese trabajo de fundación de las nuevas formas de cultura que permitirían al hombre, a la humanidad, reconciliarse con su existencia. Esto significa: acertar a darse una adecuada auto representación-como precisamente aquel ser que tiene esa tarea por misión. El conocer-se $y$ saber algo de sí merecer ostentar con dignidad el inalcanzable pero irrenunciable rango de verdadera humanidad."18

\section{Jaspers y el tiempo.}

"O se consigue el mantenimiento de la universidad alemana mediante el renacimiento de la idea comprometida con la realización de una nueva forma organizativa, o ella encontrara su final en el funcionalismo de las gigantescas instituciones de instrucción y formativas de las fuerzas especializadas de la ciencia y la técnica. De aquí que sea válido bosquejar la pretensión de una reforma posible de la universidad."

Con esa impaciente intransigencia Karl Jaspers ${ }^{19}$ describe en el prólogo de la reimpresión (1946) de su artículo "La idea de universidad (Die Idee der Universität)" su sospecha del estado de la universidad alemana de entonces. Lo cierto es que en España esta discusión sobre la reforma universitaria, de la educación, etc., no ha sido suscitada, y menos animada, por instancias extraeducativas, por instituciones extrauniversitarias, como ha ocurrido en Alemania con el debate sobre la utilidad de la filosofía y su historia, donde por ejemplo las Fundaciones -la Volkswagenstiftung, la Fritz Thyssen-Stiftung con su iniciativa Pro

18 BREA, JOSE LUIS. "Por un arte no banal -manifiesto-", publicado en el catálogo Iluminaciones profanas. La tarea del arte, San Sebastián, Arteleku, 1993. Incluido también en el libro Un ruido secreto, 1996, descarga libre en: http://joseluisbrea.net

19 Karl Theodor Jaspers. (Oldenburg, 23 de febrero de 1883 - Basilea, 26 de febrero de 1969, psiquiatra alemán y filósofo, tuvo una fuerte influencia en la teología, en la psiquiatría y en la filosofía moderna). 
Geisteswissenschaften-y Academias como la Academia de las Ciencias de Berlín-Brandeburgo, con su Manifest Geisteswissenschaften (2005) han desempeñado un rol determinante o cuanto menos provocador, cuyo eco ha tenido efecto y oídos en la política educativa a través de la convocatoria del concurso por la excelencia impulsado por el gobierno alemán; en España, conviene que lo digamos, provienen o han sido suscitadas generalmente en el ámbito de la política, y por lo mismo han entrado en el debate como importaciones para convertirse en problemáticas estériles.

Sin embargo, ello no quiere decir que debates al uso -sobre todo en relación al papel de la Filosofía y las Humanidades- no los haya habido. Precursores como Gustavo Bueno, que compartía el diagnóstico sobre la filosofía oficial española reconociendo la necesidad de su reorganización, a la vez que se oponía a la supresión de la especialidad universitaria de filosofía y su sustitución por un Instituto suprafacultativo para los científicos con intereses filosóficos, y como Manuel Sacristán ${ }^{20}$ que repudiaba la situación de la filosofía universitaria y la filosofía profesional española -filosofía licenciada y burocrática, se decía entonces- por su inoperancia y obsolescencia y por estar completamente desconectada de la realidad; ambos, inicialmente adheridos a la falange pero luego evolucionados hacia el marxismo, plantaron su controversia "el lugar de la filosofía en los estudios superiores y en el conjunto del saber", en plena época franquista y en el apogeo de las turbulencias estudiantiles europeas.

En estos momentos, y como paralelismo, estaba teniendo lugar en Francia, la fundación del Grupo de Investigación para la Enseñanza de la Filosofía (GREPH), animada entre otros por Jacques Derrida, para la defensa de esta disciplina. Aunque no directamente sobre filosofía, pero en cierto modo relacionado con esta voluntad de repensar las necesarias transformaciones del espacio de la universidad en defensa de las disciplinas vinculadas a las Humanidades, en 1998, José Luis Brea

20 SACRISTÁN, MANUEL. "Sobre el lugar de la filosofía en los estudios superiores" (Barcelona, Nova Terra, 1968) y SACristán, MAnuel. "Manuel Sacristán, papeles de filosofía", Barcelona, Icaria, 1984, Pág. 350 -380. 
puso en funcionamiento GROFAU, Grupo de Reflexión y Opinión sobre la Formación Artística Universitaria, un foro de debate online encargado de producir textos entorno a la relación formación artística-universidad, otorgando a la enseñanza universitaria del arte: "el reconocimiento de su valor cognitivo, el reconocimiento de su carácter de prácticas productoras de conocimiento, e incluso la capacidad de ostentar al respecto un poder excepcional de cara a la configuración de los procesos críticos de autorreflexión $y$ autoconocimiento por los que la humanidad alcanza la capacidad de interpretarse a sí misma." 21

\subsubsection{Interrelación Arte-Ciencia-Tecnología en el estado español.}

Favoreciendo el desarrollo e implantación de lo que venía denominándose "Tercera Cultura" uno de los objetivos que impulsó a la FECYT, en septiembre de 2003 y a propuesta de su Comisión de Humanidades, a constituir una plataforma de análisis de la interrelación entre Arte, Ciencia y Tecnología (АСт) que plasmara sus trabajos en un informe con recomendaciones para el impulso y desarrollo de esta interrelación. El grupo de trabajo constituido al efecto ${ }^{22}$ elaboró un primer informe sobre el Estado del Sistema $\mathrm{ACT}^{23}$, que incluía entre sus recomendaciones principales la de celebrar unas jornadas de reflexión que sirvieron a dos fines principales: por un lado, favorecer el encuentro y la comunicación entre los promotores de las diversas iniciativas ya en

21 BREA, José LUIS., "Idea de Universidad", publicado en Actas Congreso Inars: la investigación en las artes plásticas y visuales. Editor Alberto Mañero Pág. 460

22 En su primera composición, el Grupo estuvo formado por: José Luis Brea (Profesor Titular de Estética y Teoria del Arte, Universidad Carlos III, Madrid), Coordinador del Grupo; Arturo Colorado (Rector de la Universidad Sek y Coordinador en España de la Red ECulture.Net); Salomé Cuesta (Profesora Titular de Escultura, Artista e Investigadora en el Laboratorio de Luz, UPV); Rosina Gómez-Baeza (Directora de Arco); Anna María Guasch (Profesora Titular de Historia del Arte, UB); Simón Marchán (Catedrático de Estética y Teoría del Arte, UNED); Ignacio Riesgo Director del Mercado Creativo, Apple); y Fernando Villalonga (Directora Fundación Telefónica). En las secciones de trabajo participaron así mismo Javier Echeverría (Catedrático de Historia de la Ciencia, CSIC), como Coordinador de la Comisión de Humanidades de la FECYT, y Celia Cabello como Coordinadora de la Plataforma ACT desde la FECYT.

23 Estado del Sistema Arte-Ciencia-Tecnología. FECYT, 2004 
marcha en nuestro país, y por otro, entrar en contacto con los impulsores de las prácticas de referencia a nivel internacional, para contrastar en el encuentro las medidas más adecuadas para promover el desarrollo del sector. Las primeras Jornadas se celebraron en la ciudad Gijón en noviembre de 2004, y reunieron a cerca de 50 profesionales, entre ellos los más importantes impulsores del sector a nivel internacional, como Roger Malina, Derrick de Kerckhove y Michael Naimark.

Tras una recomposición del equipo de trabajo en 2004, el grupo ACT elaboró un conjunto de cuatro informes referidos a cada una de las cuatro grandes áreas en que se distribuyó el estudio del sector (formación, investigación, producción y divulgación) ${ }^{24}$, precedido por una introducción general de su coordinador José Luis Brea, que se presentó públicamente en la sede del Ministerio de Cultura en 2005. Al mismo tiempo el grupo promovió el establecimiento de un Censo de Recursos Аст en España que recoge, en una base de datos online, información exhaustiva sobre las iniciativas АCT existentes o en curso de desarrollo en nuestro país.

\subsubsection{Libro Blanco de la investigación en Humanidades}

En España el debate a grosso modo, versa sobre la vitalidad académica y social de las Humanidades y lo hace principalmente en torno a dos cuestiones cuyo origen, como hemos apuntado antes, se encuentra en la política, de modo que han sido importados desde ella, la política cuyos baremos son medidos en términos de réditos y a plazos no superiores a los de cuatro u ocho años, o según lo que dure el mandato. La primera cuestión es la de la adecuación de las titulaciones de Humanidades - una vez asegurada su supervivencia- al nuevo Espacio Europeo de Educación Superior (EEES); y la segunda, que tiene que ver con la presencia de asignaturas de humanidades y filosóficas en la Enseñanza Media tras la aprobación de la LOE -Ley Orgánica de Educación. En ese sentido el destino de los estudios de las humanidades y de la filosofía en

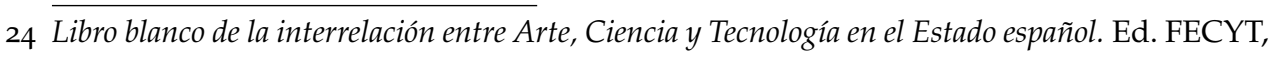
2007 
la Universidad depende directamente de su crecimiento, decrecimiento o expansión en los itinerarios curriculares de los institutos.

Desde la Comisión de Humanidades de la FECYT se realizo durante 2003 y 2004 un estudio sobre la investigación en Humanidades a través de cinco paneles de expertos, dada la gran diversidad temática de las Humanidades (Arte, Filología, Filosofía, Historia y Literatura) que propusieron la realización de una encuesta entre investigadores acreditados en cada área para detectar sus respectivas fortalezas, debilidades y problemas. Los objetivos se centraron en dos puntos clave:

1. Profundizar en los problemas comunes a las diversas áreas de Humanidades.

2. Formular propuestas generales y concretas que pudieran ser transmitidas a las diversas autoridades y agentes sociales que apoyan y promueven la investigación en Humanidades.

A la luz de los acontecimientos podemos afirmar que la percepción social de las Humanidades todavía no ha variado, sin embargo como se menciona en el informe:

\begin{abstract}
"Uno de los objetivos prioritarios de las Humanidades en la sociedad del conocimiento consiste en investigar, elucidar y mejorar el funcionamiento efectivo de las prácticas de producción simbólica (visual, narrativa) que alimentan el crecimiento de un cuarto sector (industrias de lo identitario), que resulta clave en el desarrollo de las sociedades del conocimiento". ${ }^{25}$
\end{abstract}

\title{
2.4.3 Los ordenes institucionales son formas del espíritu objetivo.
}

Lo cierto es que el discurso de Jaspers parte de la idea -asentada en las premisas de la sociología fundada en el idealismo alemán-, de que los ordenes institucionales son formas del espíritu objetivo, de modo 
que "una institución sólo es capaz de funcionar con permanencia en la medida que corporiza vitalmente la idea que le es inherente..." ¿Y qué nos dice esto? Pues nos dice que si el espíritu escapa de algún modo a la institución ésta perdería todo su sentido y toda su potencia de ser, cosa que a su vez nos muestra que el discurso sobre la idea de universidad manejada por Jaspers es de alguna manera el proyecto de la cristalización de una forma de vida, idea que tiene que ver con las leyes culturales según las cuales se constituyen todas las formas del espíritu objetivo.

Hoy no estamos muy lejos de sospechar un cierto desajuste en el rumbo normativo de nuestras universidades, pero tampoco de la nitidez de su actual Idea de Universidad, si es que de algún modo se tiene. Ya, en una de las observaciones más sensatas y críticas sobre el estado e idea de universidad, José Ortega y Gasset describió aquello que en torno a la Educación Superior en España tanto le preocupaba; por un lado, eso que él llamaba las enfermedades del tiempo actual: "Y una de las enfermedades que el tiempo actual padece, sobre todo la nueva generación, es que, merced al progreso técnico y que la organización social, los nuevos hombres se encuentren en navidad seguros de demasiadas cosas"26; por otro, los aspectos que hacían necesaria una reforma de la universidad; entonces dijo de la Universidad en su ensayo de presentación ante los alumnos de la Federación Universitaria Escolar:

"... conviene hacer constar ahora que durante años y años hemos tenido que sufrir esas inepcias y esos insultos los que con más auténtica y entrañable angustia nos oponíamos a que la Universidad española continuase siendo la cosa triste, inerte, opaca y sin espiritu que era. Porque la veracidad obliga a reconocer que hoy es nuestra Universidad bastante distinta de la que era, aunque no sea aún, ni de lejos, lo que debe, lo que puede ser.

A la hora presente, en toda la existencia nacional las constelaciones han cambiado. Han venido los hechos, con su puño cerrado, a tapar las bocas maldicientes y a convencer al más remiso de que el Estado y la Universidad de España necesitan una reforma, que

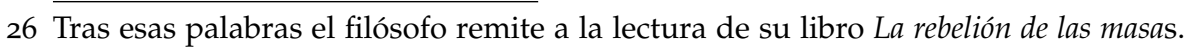


no es cuestión desearla o no, si no que su intento es ineludible, porque ni aquél ni ésta marchan. Son máquinas maltrechas por la usura del uso y la del abuso."27

La evidencia de un cierto paralelismo no garantiza de forma alguna, como sabemos, que hoy deba emprenderse una andadura similar ${ }^{28}$. Sin embargo es evidente que tengamos que hacernos alguna pregunta, por ejemplo al estilo de: ¿acaso la similitud visible entre estas dos situaciones es una similitud estructural, de fondo, de normatividad? Pues bien, antes de apartarnos de esta suerte de prolongación, nuestra respuesta es a grandes rasgos que Sí! También Gustavo Bueno, platea algo similar aunque referido tácitamente a la especificidad de la Facultad y la enseñanza de la Filosofía. En todo caso ambos, Ortega y Gasset, y Gustavo Bueno, cada uno por su lado, vienen a decir aquello que Humboldt y Schleiermacher enlazan en un mismo pensamiento referido a la Idea de Universidad cuya aspiración descansaba en la necesaria reforma que de la Universidad debía llevarse a cabo: aquello que explicando la tradición universitaria garantice la fuerza unitaria de la ciencia institucionalizada con la investigación en la Universidad y las circunstancias defensivas de la universidad respecto de las prácticas profesionales, en especial de los requerimientos formativos, que pudieran poner en peligro el principio de la unidad docente e investigación, y sobre todo -pensado en términos del papel arbitral que necesariamente ha de jugar la Filosofía, la puesta en valor del binomio "autonomía y libertad" como acentuación remisiva de la autonomía científica y la autonomía funcional del sistema resultado de la Idea de Universidad- de cómo la universidad podría llegar a institucionalizarse sin que se amenace su autonomía por otros flancos, sea a través de los

27 ORTEGA Y GASSET, J., Misión de la Universidad, Editorial Revista de Occidente, Madrid, 1930

28 Recientemente, un grupo de expertos ha presentado el informe PROPUESTAS PARA LA REFORMA Y MEJORA DE LA CALIDAD Y EFICIENCIA DEL SISTEMA UNIVERSITARIO ESPAÑOL, el 12 de febrero de 2013.

http://www.mecd.gob.es/prensa-mecd/dms/mecd/servicios-al-ciudadano$\mathrm{mecd} /$ participacion-publica/sistemauniversitario/propuestas-reforma.pdf [Fecha de consulta: 24 de abril de 2013] 
órdenes de la autoridad estatal, que posibilitaría la existencia externa de la ciencia, a través de las influencias de la sociedad civil, que está interesada en los resultados utilizables del trabajo científico y las fuerzas totalizantes del mundo de vida, a consolidar en tres aspectos concomitantes: tradición cultural, socialización e integración social. Tal vez aquello que une el pensamiento reformador tanto de Ortega, Bueno, Humboldt y Schleiermacher, respecto a la Idea de universidad es algo que -en tanto que aspiración del papel de la filosofía en la universidad-, proviene precisamente de la unión del pensamiento de los dos últimos y que funcionaba como una máxima:

"... a saber, en cuanto se conciban ideas, al mismo tiempo se les conforma en el carácter ético del cognoscente y se les libera de cualquier dogmatismo." 29

Base común, la filosofía, motor de una ciencia ensayada en la reflexión que crearía ciertamente claridad no sólo acerca de las cosas que nos permanecen ajenas, sino también sobre las raíces más profundas de nuestras vidas; pero también, en el caso de Ortega y Gasset y Gustavo Bueno, la idea -proveniente de las aspiraciones Ilustradas, aunque con un esencial matiz- de que el cometido emancipatorio puede ir junto con las contiendas políticas, conscientes además del riesgo del pago que la universidad bebería asumir con tal de garantizar la organización estatal de su libertad, a partir de los imperativos funcionales de la economía y la administración.

Cuando Max Weber nos advierte sobre la premura y el peligro del olvido, sobre todo el olvido de la Ilustración, lo que hace más bien es invitarnos a hurgar en los más riesgosos e improbables documentos constitutivos de cada Idea de Universidad y constatar que cada uno de ellos más que confundir lo que hacen es clarificar sobre las condiciones que deberían haberse satisfecho para la institucionalización

29 HABERMAS, JÜrGEN. "La idea de la universidad - procesos de aprendizaje", publicado en Sociológica, $\mathrm{n}^{\circ}$ 5, 1987. Edición online: http://tinyurl.com/mhz88u9 [Fecha de consulta: 9 de enero de 2011] 
de una ciencia como tal, a decir, estar en condiciones de garantizar automáticamente la unidad de la investigación y la docencia mediante su estructura: la unidad de las ciencias, la unidad de ciencia y formación general, y la unidad de la ciencia y, en todo caso, la ilustración (exuberante aspiración, en cuanto que autonomía de las ciencias se cargaba con la esperanza de que la universidad pudiera anticipar una sociedad de libres e iguales en el interior de sus muros y en sus microcosmos). Es esa estructura interna, fuere cual fuere el campo disciplinar de conocimiento, la condición primera para que pudiera, en términos de proyección futura, ser examina en cuestión.

\subsubsection{El debate que sobre la Universidad nos urge}

"Constituye en nuestro tiempo casi un tópico referirse a la Universidad como a una institución en crisis. La Universidad es presentada como un ente internamente escindido, como algo por consiguiente que ha dejado de ser un ente propiamente dicho, es decir un indiviso. Tal escisión se traducirá en el hecho de que los diferentes estamentos que pueblan la Universidad habrían dejado de someter las diferencias que los separan a una unidad en la que todo vendría a integrarse, constituyendo así una multiplicidad armónica, un cosmos. En otros términos: la crisis como desligamiento interno a la Universidad supondría que cada uno de sus componentes ha dejado de ser integrante; cada uno o bien ignora al otro, o bien se opone a él sin que tal oposición se resuelva en síntesis posterior". 30

Hoy en día, la rapidez con la que se dejan atrás los debates de cuestiones de enorme complejidad es proporcional a la rapidez con la que se dejan atrás, sin sonrojo alguno, las convicciones con un innegable e intenso momento de verdad. El debate que sobre la Universidad en este tiempo nos urge, parece, sin embargo, que para nada ha comenzado, al tiempo que el ratio de convicciones que debería sustentarlo se vislumbra tambaleante, distraído y quizás, tal vez, abandonado. A decir, tal abandono no denota un dejar ahí o por ahí la cuestión del debate, sino

3o GÓMEZ PIN, V., "Función de la filosofía y concepto de Universidad", prólogo a La filosofia como institución de Jacques Derrida. Ed. Juan Gránica, Barcelona, 1984. Pág. 12. 
un deteriorarse constante de la atención, un deteriorarse la posibilidad de la interpolación sobre el núcleo pertinente del mismo, sobre el límite localizado de eso mucho que nos afecta, el requisito mínimo de responsabilidad.

Manifestamos nuestra objeción a un cierto "estar fuera de lugar y de forma" del debate como posibilidad de la relación. Esto es, dicho de otro modo, un visible desfase escópico entre las fuerzas de análisis, los potenciales prácticos y las naturalezas concerniente a los ámbitos. A decir, nadie se separa de nada [nadie pretende separase de nada] con tal de optimizar los paramentos de la observación. ¿Acaso la realidad formada organizacionalmente, en la que se asientan los sistemas parciales -especificados funcionalmente- de una sociedad altamente diferenciada, no se basa sino en otras premisas, en estados previos de cosas? En todo caso, nuestra insinuación apunta hacia una cierta necesidad de distinción entre las formas de abordaje de la cuestión, las especificaciones funcionales de los dos ámbitos de la relación [ya sea éticas, políticas, morales, económicas, artísticas, retóricas, etc.], que en su lugar no sólo darían sustanciosas respuestas en relación al conocimiento del tema, sino sobre todo, inscribirían la cristalización de las preguntas pertinentes entorno también a la especificidad del discurso -basado el primero en la idea de universidad y el segundo en la idea de práctica artística- de las comunidades protagonistas de la localizada problematicidad; esto es, se haría visible el plano discursivo que conduce la cuestión debatida, o bien como un plano moral o bien como un plano ético.

Así, la cuestión pasaría por aclarar de principio la naturaleza y dimensión de la oposición existente entre modelos discursivos: uno, el de las prácticas artísticas (y no el del arte, que ya es otra cosa), y el otro, el de la universidad; oposición en la que subyace paradójicamente la contradicción de que ambos lo hacen anclados en una cierta postura de dominio, de ser algo (su Idea de...), como es lógico, con una especificidad diferenciada. Toda conflictividad entre partes tiene siempre un doble origen y lugar localizable en el núcleo fundacional $-\mathrm{y}$ de ahí una $\mathrm{u}$ otra especificidad- de cada una de ella; lo que deduce que el ámbito 
o cosa en su formulación llega a fundar también en sí, de algún modo, la posibilidad de su entrada en contradicción no sólo con sus propias partes sino con cualquier otra cosa o ámbito que circule en la misma órbita de intereses. Un ejemplo que puede servirnos es el análisis que Habermas hace de "La idea de universidad (Die Idee der Universität)" de Jaspers ${ }^{31}$, contraponiendo los dos momentos de inscripción de la necesidad de reformar la universidad, en la que -y aunque referidas al ámbito de las reformas universitarias en Alemania, pero que igualmente a nosotros nos sirve- a través de la formulación de dos preguntas que describen tanto la dimensión de la problemática universitaria como la dirección de los juegos de intereses, deducidos de las posturas discursivas de cada momento:

"Después de que se disiparon las nebulosidades de la polémica acerca de la entretanto dispuesta universidad grupal, con resignación se centran las miradas en torno a una paisaje universitario polarizado. ¿Qué podemos aprehender de estos veinte años? La cuestión se nota como si esos realistas conservaran con derecho, lo que ya habian aclarado -como Jaspers observa- luego de la primera guerra mundial: " $\mathrm{La}$ idea de la universidad está muerta!". " Desprendámonos de las ilusiones!". "No corramos más en pos de ficciones!". ${ }^{2}$

En relación a los postulados críticos de Jaspers, tras veinte años y una reforma de la organización de las escuelas superiores realizada a medias y en parte de nuevo retomada, y los intentos (por todos los lados) de disociación de los intentos de conferir una forma novedosa a la universidad, Habermas pregunta:

31 HABERMAS, JÜRGEN. "La idea de la universidad - procesos de aprendizaje", publicado en Sociológica, (Revista del departamento de Sociología). Vol: año 2, $\mathrm{N}^{\mathrm{o}}$ 5. 1987. Universidad Autónoma Metropolitana de Azcapotzalco. México. Edición online: http:/ / www.revistasociologica.com.mx/pdf/0505.pdf [Fecha de consulta: 9 de enero de 2011]

32 Íbidem, pág. 3 
“¿O es que acaso no hemos entendido correctamente el papel que por consecuencia pudiera jugar una idea tal, para la autocomprensión de los procesos de aprendizaje universitariamente organizados? ¿No será que la universidad debería desembarazarse de lo que una vez se ha denominado 'su idea', tirarlo como se hace con una cáscara vacía, en su camino hacia la especificación funcional en el interior de un sistema científico diferenciado aceleradamente? ¿O tal vez la forma universitaria de los procesos de aprendizaje organizados científicamente aún hoy se encuentra sujeta a un entramado de funciones, que no demandan precisamente un modelo normativo, pero sí una cierta comunidad en las autointerpretaciones de los universitarios, ya que son el resto de una conciencia corporativa?"

Es probable que visionar o revisar el desarrollo tanto exterior como interior de las universidades sea suficiente como para encontrar las respuestas a estas preguntas. Es en ese sentido que se harían visibles también las fuentes de emanación de discursividad -en términos de temporalidades, anacronismos, evolución y usos- correspondientes a cada parte, y por tanto el lugar mismo del origen de la contradicción, y entonces de la posibilidad objetiva del debate. Un umbral de cosas donde parece ser que al debate sobre la cuestión práctica artísticauniversidad le urge -para que se haga lugar y derecho a ser tal cualuna replanteamiento de la postura discursiva en la que esta entablado: desprender el núcleo de ambas cosas en relación -práctica artísticauniversidad- de las cubiertas de sus simplificaciones.

“... podríamos enumerar los tres rasgos que definirían nuestra idea contemporánea de la Universidad. El primero, la autorreflexión, que determinaría una diseminación de las responsabilidades de la legitimación a los juegos de habla de las ciencias particulares, sobre las que recaería el trabajo de establecer su propio grado de teoricidad y por ende sus mecanismos autónomos de legitimación. El segundo, la interactividad entre ellas, en el establecimiento de una red de intercomunicación retroactiva en el seno de cuya constelación se configuraría la imagen del conocimiento como 
juego abierto de información incompleta. El tercero, finalmente, el énfasis investigador de esta política de enseñanza, apoyado en la figura del disentimiento como criterio asegurador del progreso del conocimiento." 33

\subsubsection{La cuestión de la relación práctica artística-universidad}

“... que es responsabilidad de las autoridades del Estado abordar e impulsar (pues no se va a producir desde dentro) esa transformación urgente de las instituciones formativas que se mueven en el campo del uso experto de las herramientas de visualidad, para propiciar cuanto antes la necesaria superación de ese estado de desajuste que hace que cada año nuestras facultades de arte (concebidas a la medida de un perfil del artista poco menos que decimonónico) entreguen al tejido social varios miles de profesionales mal preparados para las funciones que éste realmente demanda de ellos, hablando tanto en términos estrictamente profesionalistas como en los no menos importantes de su nueva función antropológicocrítica.

Esa nueva función reclamada por un "Arte del Futuro" que es, o debería ser, el de nuestros días, a falta de que tanto las instituciones culturales como las propias educativas adapten sus estructuras a esas nuevas necesidades y lógicas, que llaman a nuevas funciones no desde un futuro remoto y lejano, sino desde ese Futuro inmediato que es la exigencia moral de nuestro propio hoy." 34

La cuestión de la relación práctica artística-universidad no es un problema viejo, como no lo es tampoco la universidad, y ni siquiera lo es fundamental por cuanto es artificial: es un problema de políticas

33 BREA, JOSÉ LUIS. "Idea de la Universidad" en Actas Congreso INARS: la investigación en las artes plásticas y visuales. Ed. Congreso INARS, Sevilla 1998. Pág. 460.

34 BREA, JosÉ LuIs. "El Arte del futuro (y su urgente enseñanza)", publicado en Red digital: Revista de Tecnologías de la Información y Comunicación Educativas, $\mathrm{N}^{\mathrm{o}}$. 3, 2002 Edición online: http://reddigital.cnice.mec.es/3/firmas/firmas_brea_ind.html [Fecha de consulta: 22 de octubre de 2010] 
de relación. A saber, es un problema sobre la relación y no de la relación, que evidentemente ha de ser explicado aunque no tanto desde la proyección conveniente de las prácticas artísticas con vocación universitaria como sí desde los presupuestos tendentes a su exclusión. En este paso cabe pensar en una unidad, o en la posibilidad de que lo sean, ante la intuición de que no es así. No son y no serán una unidad de relación aunque si una unidad conveniente siempre y cuando, para saber que ha ocurrido en ellas, en el análisis se las separa. Así cada una mostrará necesariamente su pensamiento; la primera, la idea de práctica artística que, a su vez, explicaría toda su tradición y la relación afirmativa con los campos disciplinares humanísticos, además de su proyección apolítica de cara al estado; la segunda, la universidad, exhibirá aquello que ata su idea a su concepto de Universidad y explicará las características de la tradición universitaria, haciendo comprensible su relación afirmativa con la ciencia, el conocimiento, la sociedad y el estado.

Es en la diferencia, en la acción de buscarla, entre el hoy de la vocación universitaria de las prácticas artísticas y el ayer de los presupuestos tendentes a su exclusión, en planos entonces de actualidad, donde en cierto modo debería deducirse la posibilidad (la pertinencia quizás) del debate. Debate, a saber, que sólo podría ser emprendido bajo una especial condición, entonces afín al conjunto de los individuos dispuestos a la acción crítica deducida de la posibilidad de debatir, la de la libertad personal del pensamiento ${ }^{35}$; condición que se da, en sentido kantiano, si coinciden superpuestos el uso universal, el uso libre y el uso público de la razón, aunque también es posible consolidarla fuera de ese sentido si la herramienta condicional es una herramienta de índole necesariamente ética centrada en la responsabilidad. Responsabilidad, a decir, que necesariamente haría visible el conjunto de límites naturales y propios de las partes de la relación -práctica artística y universidad. En todo caso sería el plano ideológico, constitutivo entonces de las

35 FOUCAULT, M., “Qué es la ilustración?” publicado en Daímon Revista Internacional de Filosofía. $\mathrm{N}^{\mathrm{o}} 7$ (1993) Universidad de Murcia. Edición online: http://revistas.um.es/daimon/article/download/13201/12741 
tensiones-problemáticas, lo que a fin de cuenta debería ser explicado. En ese sentido la forma de mostrar las fuentes de tensión natural y sus funciones en el plano de aportación a la cultura, tanto de un ámbito como del otro, ganarían la nitidez necesaria como para, en el haber sido localizadas, visibilizar las nuevas formar de tratamiento del mundo de vida, en principio, y de su producción tanto de simbolicidad como de artefactos técnicos, después, a modo por tanto de baremo diferenciador con aquello que ya hace lugar, bien como instituido, bien como reconocido o bien, como institucionalmente legitimado.

La idea que aquí cobra cuerpo es la de considerar las definiciones de los ámbitos de la relación en términos de cada naturaleza en cuestión, para poder de esa forma dilucidar la relacionabilidad y las tensiones, o no, de las dos formas de gestionar la representación, y así mismo, la investigación, el conocimiento y la cultura. Ahora bien, aquí como es obvio salta la pregunta al estilo de: ¿qué supone todo esto de las definiciones de los ámbitos de la relación? Pues ello supondría la activación necesaria de todos los protocolos de reconocimientos que darían objetividad no sólo al debate sino, algo más importante, a la posibilidad (la aspiración, ya como proyecto) de que la relación sea un hecho.

Dicho problema, podría ser artificial, en tanto no dice de sí su potencia de problema-conocimiento. Esto, dicho de puntillas, supondría que lo que empuja a la problematicidad, entonces llamada "de la relación práctica artística-universidad", atañe, por un lado, a un conjunto de cuestiones de índole bien distinta al de la relación-problema, y por otro, que el problema tal cual es de índole indirecta, o lo que es lo mismo, de intereses externos o fluctuaciones basadas en rendimientos ideológicos y nunca en términos de roles o de proyectos, entonces, en torno a la relación. En todo caso, de la relación, la cuestión de la Universidad parece ser, sin quitar la importancia necesaria a las practicas artísticas, la cuestión central a la que nuclear la otra parte de la relación, o sea, la práctica artística. Lo es porque es la propia Universidad la que sostiene (ha sido siempre así en la universidad moderna, cosa que en posteriores análisis deberíamos seguir pensando en términos entonces de censura, 
de la censura que ejerce para sí la propia universidad) el motor de la conflictividad entre disciplinas, el motor, dicho con palabras de Kant, del conflicto de las facultades ${ }^{36}$; conflicto apartado del debate necesario a base de premuras y de decretos, pero sobre todo apartado del debate a causa de la potenciación de olvido 37 .

Parece como si hubiera desaparecido de nuestras conciencias la densa complejidad que dio lugar a la fundación de la Universidad actual, a la formulación del conjunto de relatos necesario para su puesta en marcha, $\sin$ que para nada hayamos traído sus momentos de verdad ${ }^{38}$. Tiene sobrada razón Juan José Sánchez ${ }^{39}$ cuando en su texto de introducción a la edición de Dialéctica de la Ilustración (1998), se refiere a la ambigüedad concerniente al proceso formativo de la Ilustración y por extensión a la modernidad y a sus instituciones (entonces la profanización de la cultura occidental con las artes convertidas en autónomas ${ }^{40}$, la evolución de las sociedades modernas, etc.), pero más cuando enfatiza acerca de las consecuencias, en cuanto perdida, si esa complejidad formativa -aquella referida en términos de racionalización a la institucionalización de la acción económica, la acción administrativa, la racionalización cultural o la disolución de las formas tradicionales de vida diferenciadas con arreglo a fines, o aquellas propias de la ilustración, ligadas a la universalización de las normas de acción, la generalización de los valores y los patrones de socialización tendentes al desarrollo de identidades del yo, etc.- en algún modo ignorada o, en el peor de los escenarios, si

36 KANT, IMMANUEL. El conflicto de las facultades. Alianza Editorial, 2003. Madrid

37 "La rapidez es el fruto de un olvido: de no tomar suficientemente en serio la Dialéctica de la Ilustración". Adorno, Theodor W y Horkheimer, Max, en Dialéctica de la Ilustración. Editorial Trotta. Colección Estructura y Proceso, Serie Filosofía, 1998.

38 Sánchez, Juan José. "Sentido y alcance de la Dialéctica de la Ilustración", texto de introducción a Dialéctica de la Ilustración. Adorno, TheOdor W. y HorkHEIMER, Max. Ibídem.

39 SÁnchez, JuAn José. Dialéctica de la Ilustración. Ibídem.

40 Para Habermas, Max Weber describe bajo el punto de vista de la relación no contingente entre modernidad y lo que llamó racionalismo occidental, en el desarrollo de problema de historia universal, no sólo la profanización de la cultura occidental sino sobre todo la evolución de las sociedades modernas, Pág. 12. HABERMAS, J., Discurso filosófico de la modernidad. Ed. Taurus Humanidades. Versión castellana de Manuel Jiménez Redondo, 1993. 
aquella dialéctica [de la ilustración] es de forma alguna olvidada.

En ese sentido aún cabría una dirección reflexiva o de debate; una que debería ser capaz de poner en crisis al propio debate y del mismo modo la idea actual y pasada que de la Universidad tenemos. Sería, a modo de pregunta, algo así: ¿Qué diferencia introduce el hoy de la Universidad en relación al ayer, a su ayer? A fin de cuentas debería interesarnos más esa diferencia, la búsqueda de ella [la diferencias] entre éste hoy complicado y ese ayer complejo, que, en cualquier caso intentar, comprender el presente en base a una realización futura o de algo que bien se le parece, en base a una inexplicable totalidad. Sería así, si tenemos en cuenta que una de las aristas que acotan la definición de uno de los ámbitos-parte (el marco especular) de la relación a pensar, en este caso, se ha vuelto entonces visible.

Las inscripciones de resistencias, visibles en la antinomia de los relatos que la funda, han tenido lugar desde el inicio mismo del modelo de Universidad moderna, como ocurre con Kant. Fue Kant precisamente quien en su último libro, El conflicto de la facultades (compilación de varios escritos en tres partes, fechado en 1794), hace publica la observación de las batallas e incertidumbre que en torno a la autonomía y el potencial crítico de la joven universidad moderna, estaban teniendo lugar. En torno a dicha reflexión (y teniendo en cuenta la relación practica artísticauniversidad) sugerimos que no se siga formulando según el modelo histórico (tal como ocurre con las disciplinas correspondientes al área de las ciencias e incluso, como hasta hace algún tiempo se ha hecho con las humanidades, en relación a estándares, exigencias políticas y obligaciones de/y para asumir la investigación); sugerimos se haga en el sentido que aporta el enfoque del proyecto interdisciplinario de la cultura visual, o sea, en un sentido antropológico que a su vez guardaría un especial relación con un panorama y concepción de lo visual fundado en lo multidisciplinar, la virtualidad y la gestión e intercambio intenso de simbologías, sentido, por tanto, más en consonancia con los imperativos históricos-sociales, los imperativos semióticos y con los nuevos modelos de contextualidad y de texto. Imperativos y modelos (históricos-sociales, de contextualidad y de texto) cuya natural extensión 
práctica, a la vez que insufla energía al nuevo pensamiento, también interroga sobre los viejos relatos que impulsaron el surgimiento de la idea moderna de la universidad.

"Qué queda de ellos en la universidad real", era la pregunta que constantemente formulaba José Luis Brea cada vez que volvía sobre la relación práctica artística-universidad, que tanto le apasionaba, pero sobre todo a la idea de universidad que tanto le preocupaba. Pero, y acaso la materia prioritaria del debate sobre la Universidad -en este caso, sobre la relación practica artística y universidad- no debería circunscribirse a la propia naturaleza de la encomienda (el encargo social de índole humanista) de hacer evolucionar al conjunto de las ciencias, los saberes y el arte, en el contexto de las funciones que de algún modo les han sido atribuidas por el campo de poder. Hoy, la universidad, parece haber abandonado la potencia humanista de sus ideales fundacionales. La universidad no es feudo absoluto de las ciencias -esto es evidente desde el conformado inicial de la coalición Universidad, donde, desde el inicio mismo, ya entonces colisionaba con el modelo-relato del Espíritu Absoluto proveniente de la idea de Universidad de Berlin-, no es disciplina de fe ni de poder sino, y es esa su extraordinaria y noble tarea, un espacio social de gestión, circulación y potenciación crítica de los saberes y de los conocimientos; espacio, como es evidente, también concerniente a las prácticas artísticas, "prácticas efectivamente autoreflexivas -y que justamente por serlo, y sólo por ello, es la Universidad su lugar natural."41.

2.4.6 Sobre la evidencia del desajuste entre "función social real" e "idea regulativa".

El germen de eso que Brea llama desajuste entre "función social real" e "idea regulativa" deberíamos reconocerlo en el carácter antinómico de lo moderno, y en consecuencia en los dos ejes fundacionales del proyecto

41 Brea, José Luis. "La idea de Universidad", publicado en La investigación en las Artes Plásticas y Visuales. Serie Colección Abierta. Núm.: 61. Universidad de Sevilla Secretariado de Publicaciones, 2003. Sevilla. Pág. 439. 
no sólo de la modernidad, sino también de la Idea de Universidad, de su pedagogía y de la enseñanza superior que en parte, como herencia o influencia incompleta ${ }^{42}$ aún nos alcanza. Hablamos por tanto de los dos grandes espíritus fundacionales de la Universidad contemporánea y, por lo mismo, de los dos grandes relatos de la enseñanza y de la pedagogía moderna; por un lado, el que proclama la emancipación de la humanidad a través del progreso de la ciencia, entonces impulsado por el modelo docente propio de la II República francesa, y, por el otro, el del Espíritu Absoluto, defendido desde la Universidad de Berlín, que tomaba legitimidad a la vez que la proyectaba en la idea de la necesidad de la unidad de los saberes. El modelo docente propio de la II República francesa se desliza, y plantea, la posibilidad de la emancipación del ciudadano a través del progreso de los saberes en tanto que legítimo derecho y expresión de la voluntad de emancipación a la que institución pedagógica del estado debería dar respuesta (la ciencia como la educación, concebidas entonces como un derecho de los pueblos, deben, desde las instituciones científicas y educativas, servir a sus intereses como instrumentos fundamentales del progreso emancipatorio del sujeto social en su avance por la historia) y encomendársela como tarea a consolidar, en el sentido de la consecución de su emancipación y de mejora de la actividad cívica y en consecuencia de la nación.

Tal vez, lo que como teoría de sí se ha producido en la Universidad -el pensarse el rol justo en una contemporaneidad abierta y múltipleha lindado con un cierto juego, y pensamiento, de intereses sobre sí, minando aquello de la coherencia ${ }^{43}$ como criterio para el ejercicio de la

42 Habermas, en El discurso filosófico de la modernidad (1985), apunta hacia esa relación incompleta cuando a través de la figura de Max Weber en sus ensayos sobre el problema de la historia universal, insinúa una cierta duda sobre el alcance y carácter de universal, y por tanto no contingente, del proyecto racional y moderno -Weber describe bajo el punto de vista de la racionalización no sólo la profanización de la cultura sino sobre todo la evolución de las sociedades moderna- al preguntarse sobre "la cuestión de por qué fuera de Europa, 'ni la evolución científica, ni la artística, ni la estatal, ni la económica, condujeron por aquellas vías de racionalización que resultaron propias de Occidente'." Pág. 11

43 HELER, MARIO. Jünger Habermas y el proyecto moderno: cuestiones de la perspectiva universalista. $1^{\text {a }}$ Ed. Biblios. Buenos Aires, 2007 
teoría, cuando ésta, al describirse a sí -y por tanto conceptualizarse en relación a las problemáticas previas a su autodescripción-, se vincula a la historia. En relación a éste supuesto de la coherencia de la Universidad, del deslizarse descontrolado en la también relación pensarse-escribirse críticamente, parece haber fallado la observación de que "las estructuras generales del mundo de la vida, sólo se imprimen en las formas de vida particulares", aquella suerte de descripción de reglaje descrita por Habermas como razón de cuidados primeramente, y luego, como alerta de rigor; en todo caso, lo que dicho fallo describe es la separación progresiva de la Universidad, y de la de Universidad, no sólo de los iniciales relatos fundacionales, sino sobre todo, el anunciarse constante aquello cuyo servicio y vocación alimenta, el pretender emancipatorio de la sociedad en relación a su historia. Se describe así un estado de separación de la Universidad de Universidad, de lo que ata su idea a su concepto ${ }^{44}$.

No se trata aquí, por tanto, en nuestro caso, de una actitud o voluntad teórica que pretende tematizar el abordaje de la totalidad de los saberes de fondo que circundan la idea de la Universidad, sino de testimoniar que ese lugar particular de las formas de vida particulares, son lugaresobservatorios de criticidad, intensos y dinámicos, cuya sensibilidad (autoreferencialidad, en el sentido de que los pueblos conocen y saben sus historias, e interpretación, en el sentido de su re-lectura, de como hacer de ella una lectura actual) progresivamente ha ido tornándose cuerpo e instrumental de conocimiento y de acción. Entonces ¿para dónde tirar, a qué apuntar? Tal vez se trata de desempolvar una herencia,

44 DERRIDA, JACQUES. “¿Qué hacer de la pregunta «¿Qué hacer?»?” publicado en El tiempo de una tesis. Desconstrucción e implicaciones conceptuales, Proyecto A Ediciones, Barcelona, 1997, pág. 29-39. Edición digital Derrida en castellano: http://www.jacquesderrida.com.ar/textos/que_hacer.htm [Fecha de consulta: 18 de febrero de 2011] "Sin embargo una cierta revolución en la idea misma de revolución, en su concepto y en sus esquemas [para hablar como Kant: en lo que ata su idea a su concepto y a su intuición], en su simbólica, en sus imágenes, en su teatro y en sus escenarios, otra revolución -y de aquí otra contraseña para la justicia, la igualdad, la emancipación, etc.- otra revolución no tan sólo es lo que nos comanda la respuesta a la pregunta ¿Qué hacer? Es por más difícil, por más indiscutible que pueda parecer, sino además y ante todo es lo que nos inspira y comanda y dicta en nosotros la pregunta ¿Qué hacer?" 
extraerla del olvido y de la premura, y hacerla encajar en nuestra actual y especifica problemática, asumiendo el entusiasmo del uso que Jacques Derrida 45 en su retomarla le dio; a decir, esa herencia que tal vez no pueda ser desplegada en toda su potencia pero que ha de servirnos, aun distinguiendo la especificidad aguda de nuestro tiempo y que nos viene formulada desde ella, es la pregunta moderna ¿Qué hacer?

45 DERRIDA, JACQUES. Ibídem. 


\subsection{CULTURA_RESPONSABILIDAD_UNIVERSIDAD}

Cualquier afirmación especificada en una puntual abstracción del ámbito cultural al que pertenece (personal, comunitario, social, institucional, político, etc.) podría tornarse contradictoria en relación al conjunto de otras aseveraciones culturales «amplificadas» en torno a la misma aproximación estratégica de una idea de verdad cultural, de un todo cultural, o en relación a la simultaneidad de otras afirmaciones convenientes al ámbito contextual originario. Podría tornarse contradictoria en tanto su resistencia crítica - correspondiente en principio al contexto, y luego, al supuesto de la afirmación: siempre una nueva realidad y otra forma de diversificación - se vería afectada [en ello ha de suponerse como posible una negación] por el impulso antagónico del conjunto aseveraciones-simultaneidades culturales que tiende, en principio, a la uniformización y, en el peor de los casos (dada por supuesta la negación), a la anulación más que parcial, total, de la afirmación especificada. En la sociedad actual como escenario complejo de nuevas realidades interrelacionadas esta fragilidad de la «afirmación particularizada» ante el conjunto y simultaneidad de «afirmaciones convenientes» supone un problema, cuyo origen está en las formas de diseño y distribución de lo social [lo político, lo cultural, lo social es un producto y como tal es concebido], y sus consecuencias se verán reflejadas en el individuo en forma de una pérdida de esa capacidad de afirmación: que no es más que la aceptación sin límites de la idea de modelo de cosa expuesta por la gran institución o el gran media. Y decimos «gran institución o gran media» para dar a entender la connotación de las grandes estructuras de poder, la connotación de sus actuaciones en el ámbito tanto de lo político, lo económico y lo social como base [figura-iceberg] y dimensión de innumerables conflictos o contradicciones de índole cultural.

Contradicciones culturales siempre las ha habido. Sin embargo, en la sociedad actual como escenario de una inestabilidad especialmente compleja, lo significativo es que el conjunto de esas contradicciones de índole cultural [incertidumbre del conocimiento, de la condición 
humana, de la relación entre las partes y el todo, del individuo, de la idea de lo global, de la sociedad, la nación y el estado] es lo que la acentúa y hasta cierto punto le da carácter. Acento y carácter cuyo reflejo-consecuencia se hace visible en un arco que se abre desde la proyección individuo-sociedad hasta la proyección nación-institución-estado; desde la individualidad — ciudadano, sujetoque simultánea innumerables aceptaciones ante la pérdida de la capacidad y la autonomía de afirmación, hasta la institución cuya estabilidad se asienta en su capacidad de gestión de la uniformización, o, lo que es lo mismo, la capacidad de producción y gestión de consenso, como representación nostálgica del deterioro definitivo de su autonomía. Es precisamente en un panorama como este, en un escenario complejo e inestable (multidireccional, aunque se crea lo contrario), de incertidumbre de la condición humana, el conocimiento y su historia, en el que ha de analizarse la Universidad: la nueva idea de Universidad y su proyección resistente, o no, para absorber los nuevos métodos, disciplinas investigativas y direcciones de los saberes técnicos, como disipación de la bruma que ha de hacer ver la real aspiración de redescubrirse [pensad en la agónica y conveniente condición de institución de la universidad] como entidad-institución, o institucional (por dependiente), productora de comunicación y comunicadora de conocimientos.

Anclada la universidad en medio de la cuestión de las contradicciones de tipo culturales ha de ser tratada desde dos posibles ángulos de mira: El primero debe ser desde el enfoque de la universidad en su condición institucional, y por tanto, dependiente de un gran número de poderes, y así pues, como correa de transmisión tanto de sus aspiraciones como de sus crisis. El segundo ha de ser desde el enfoque del estado de la universidad como una consecuencia; o sea, la universidad en su condición de institución, y por tanto, de poder resistente y protector de sus propios errores, y en ese sentido afectada por su propio contexto: en uno de los supuestos, de manera directa, y en otro, indirectamente. Ahora bien deberíamos tener en cuenta que en nuestro análisis distinguimos entre la Universidad, esa institución cuyo carácter primo 
parece ser humanista, y los otros tipos de instituciones de investigación vinculados indirectamente a ella. Como simple aproximación, todos esos registros de salida corresponden y muestran en gran medida la realidad de la Universidad. Sin embargo para abordar su problemática desde el contexto de la globalización creciente de los sistemas económicos, culturales y políticos y de la incesante transformación de las tecnologías de la comunicación, es necesario discernir entre estos dos modelos de institución a simple vista confusos [o si se quiere, superpuestos] en cuanto a los modelos y forma de uso, trasvase y comunicación de la información.

\subsubsection{La irreversible transformación.}

"La universidad está pasando de ser un aparato educativo del estado, en palabras del propio Althusser, o más benévolamente, un lugar de pensamiento crítico e innovador, a ser un lugar más entre muchos otros, quizás un lugar cada vez menos importante, debido a la producción y transferencia de información intercambiada mundialmente." 46

El ámbito de la Universidad de hoy es más complejo de lo que realmente pensamos, mucho más abierto, irregular y tendente a la indefinición de su lugar y papel en una retícula social también cada vez más abierta, diversificada y de trasvases dinámicos. Pensemos por un instante en la relación «apertura, diversificaron y trasvases versus indefinición de papel y lugar». ¿Contradictorio? Al parecer, de esta relación de devenires es de donde surge eso que intuimos interrogante, que intuimos como contradictorio. Sin embargo, pensemos una segunda vez en la figura multicondicional de la Universidad y advertiremos tres ejes condicionales fundamentales para una hipotética detección de su papel y lugar que son: su condición institucional: aparato educativo del estado; su condición de institución: un lugar de pensamiento crítico e innovador, y su condición de

46 HILLIS MILLER, J. Los estudios literarios en la universidad transnacional. Ediciones Episteme, Valencia, 1996. Pág. 4. 
empresa: lugar de desarrollo de sofisticadas iniciativas estratégicas, tecnológicas e investigativas de carácter privado. Ante esta relación ha de suponerse que cada uno de los centros condicionadores, exceptuando la universidad misma, por su propia condición de institución — de fondo todavía esencialmente humanista-, tensa su interés invariablemente [resisten a la información estratégica que no conviene] redirigiendo la atención práctica hacia zonas operativas preestructuradas, con fines nítidamente marcados. Tal vez de manera acusada y esquemática advertimos la configuración del marco de acogida y proclama — matizado de inicio por esa gran contradicción, claramente protegida, claramente protectora del error, de la tripolaridad condicional-, las bases defensivas de una idea de Universidad justificada únicamente por su naturaleza institucional, por tanto por su condición dependiente: la politización de la universidad mas que su incondicionalización.

Ahora bien, pensada esta relación de ambigüedad en la órbita de la universidad, ello debería sugerirnos la visualización y análisis de algunas situaciones de naturaleza específicamente institucional ubicadas en tres zonas de operatividad, aunque posiblemente orientadas hacia objetivos distintos pero perfectamente estructuradas, como lo son:

1. El reconocimiento y gestión de la «libertad incondicional de cuestionamiento» en la universidad española y europea.

2. La imagen de la universidad Europea (política y poderes universitarios, proyecto humanista y dependencia económica).

3. El sentido y/o posibilidad de vertebración de un proyecto de Estudios Superiores: la Universidad de nuevo tipo.

Si centramos la atención en estas zonas podemos advertir, y así señalar, constantes desplazamientos o crisis con las que convivimos: disciplinas académicas, tecnologías comunicativas, educación artística, transformaciones de la imagen, crítica cultural, proyectos de investigación, universidad de la cultura, sociedad postmoderna, tecnoburocracia. En este complejo espacio, de difícil delimitación, convergen lo institucional-universitario, que crece hacia el interior de la estructura como protuberancia proyectada desde, con y hacia, la naturaleza de la universidad (marco legal, política universitaria, 
procedimientos de admisión, evaluaciones, rendimiento) y la experiencia de su visibilidad - lo visual universitario - luce hacia el exterior el traje evidente del predominio de lo espectacular mediático en las sociedades contemporáneas y su socialización soporta la afectación de todos y cada uno de sus ámbitos, comprendidos desde la cotidianidad de sus usos hasta la estandarización de lo académico. La impresión que recibimos hoy de la institución educativa es la idea de una universidad difusa [irregular y tendente a la indefinición de su lugar y papel] cuya imagen parece ser algo inexistente, todavía por alumbrar, entre la mayoría de los miembros de la comunidad universitaria.

En tal sentido, a nivel de la cotidianidad de la práctica docente, percibimos que en la búsqueda de la excelencia parece tener, o quizás importa más, el marco de calidad, acreditación y excelencia, que la enseñanza impartida o que el proyecto humanista y los productores del proceso educativo, propiamente dicho. En todo caso, constatar esta situación (bien analizada por Bill Readings en su libro La universidad en ruinas) no implica permanecer en ella: el hecho de percibir la universidad como un organismo burocrático preocupado casi exclusivamente por los indicadores de gestión y la acreditación de la calidad, no invalida la búsqueda de alternativas y la propuesta del diálogo como alternativa: las transformaciones deberán engendrase desde dentro, deben ser impulsadas por los propios productores del proceso educativo.

\subsubsection{Responsabilidad, cosmopolitismo, ciudadanía.}

Carlos Thiebaut — quien reclama la responsabilidad ante el futurojustifica la argumentación de su propuesta a partir del Manifiesto de Marx, y sugiere que debemos releer a los clásicos partiendo de los problemas presentes; superponer, si se quiere $-\mathrm{y}$ en toda relectura hay una recuperación-, la compleja retícula de lo que acontece o va teniendo lugar, al trazado, alcance y métodos con la cuestión que fue, si no problematizada al menos insinuada entonces. En tal sentido, como aproximación a esos entrelazamientos con algunas cuestiones tratadas por Marx, Carlos Thiebaut propone: 


\begin{abstract}
"Quizá por primera vez en la historia de la especie estamos accediendo a la conciencia de nuestra responsabilidad ante el presente y ante el futuro, ante la humanidad presente y ante la humanidad futura." 47
\end{abstract}

Esta toma de conciencia señala dos grandes temas ante los cuales no podemos dejar de percibir y experimentar, en primer lugar, las crecientes desigualdades respecto a los recursos, las capacidades sociales, el incremento de la desposesión y el conflicto en las sociedades contemporáneas. En segundo lugar, nuestra relación con la naturaleza, con la posibilidad de legar - ceder haciendo- un mundo natural y socialmente habitable a las futuras generaciones. Si «las épocas se definen, en gran parte, por las imágenes que acuerdan darse a sí mismas» $4^{8}$ deberíamos crear un marco adecuado de interpretaciones donde la cultura científica y la humanística no aparecieran enfrentadas y, algunas oposiciones binarias tales como conocimiento utilitarista frente a conocimiento desinteresado -investigación contra enseñanza, cultura occidental frente a culturas no occidentales-, delimitaran un nuevo espacio para la responsabilidad cosmopolita y el ejercicio democrático: ese nuevo espacio podría ser el de las nuevas humanidades, de la responsabilidad, pero no sólo en términos de disciplinas o saberes, sino abarcadores en la aspiración de un modelo de hombre del futuro también humanista en tanto que ésa sea la herencia cedida por la universidad.

"La investigación en Humanidades contribuye al desarrollo de la capacidad crítica y de criterios éticos imprescindibles para la preservación y el conocimiento de la sociedad presente y pasada".49

La idea de la responsabilidad ante el presente y también responsabilidad en el contexto de la institución universitaria, entraña necesariamente estimular la cuestión del qué es y por qué tomar conciencia de la responsabilidad, o mejor: "¿Qué representa una responsabilidad

47 THIEBAUT, C., La responsabilidad ante el futuro (y el futuro de las humanidades). Ediciones Episteme, Valencia 1999. Pág. 23.

48 Ibídem., pág 31 .

49 Libro Blanco de la investigación en Humanidades. Ed. FECYT. Pág. 49 
universitaria?» $5^{\circ}$ Sin embargo también supone la aprehensión clara de la noción e idea de universidad, y principalmente, saber si la relación de ambos conceptos responsabilidad-universidad pueden ser separados o no. Ahora bien ambos conceptos en esa aspirada relación deberían dar lugar al desarrollo de un espacio crítico «dentro» de la institución, donde la imagen de universidad ya no sea la de una fortaleza o ciudadela elitista de saberes, y tampoco como fábrica del conocimiento, sino mas bien la idea de laboratorio [abierto, dinámico, y expuesto a que nada quede resguardado de ser problematizado] siempre en proceso, y con vocación generativa y colaborativa entre el conjunto de miembros de la comunidad universitaria. Esta relación resolvería la cuestión del progresivo individualismo competitivo que está teniendo lugar —en porcentajes alarmantes-, en el seno de las distintas áreas académicas, cuya repercusión esta evidenciándose en forma de marginalidad, en forma de una comunidad universitaria desmantelada: una comunidad sin comunicación, visible en una larga cadena de grupos irreconciliables, pugnando, así mismo, por hacerse con el control de esas áreas de conocimiento estancas.

Así mismo la relación responsabilidad-universidad resolvería también la cuestión de las mutaciones que afectan al lugar y la naturaleza del trabajo universitario pero no sin que antes haya sido necesario desarrollar nuevas formas del trabajo académico [responsabilidad/pedagogía, responsabilidad/profesión, responsabilidad/política, responsabilidad/teoría, responsabilidad/saber] desde el espacio de unas nuevas humanidades, humanidades transformadas que deben "hallar -dicho en palabras de Jacques Derrida- su lugar de discusión incondicional y sin presupuesto alguno, su espacio legítimo de trabajo $y$ de reelaboración, en la universidad $y$, dentro de ella, con especial relevancia, en las Humanidades. No para encerrarse dentro de ellas sino, por el contrario, para incluir el mejor acceso a un nuevo espacio público transformado por unas nuevas técnicas de comunicación, de información, de archivación y de producción del saber. ${ }^{51}$.

50 DERRIDA, J., La filosofía como institución. Ed. Juan Granica, Barcelona, 1984. Pág. 21

51 DERRIDA, J., La universidad sin condición. Ed. Trotta, Madrid, 2002, pág. 12. 


\subsubsection{Filo ciego: el espacio por ser}

En el ámbito de la universidad de hoy, en el que encontramos apelativos como calidad, mayores niveles de excelencia, cultura de la evaluación, competencia, eficacia y eficiencia, que recorren el marco legal que la constituye como institución, se percibe una acelerada sobreadaptación de los sistemas de enseñanzas a las demandas definidas por la lógica empresarial y comercial, pero también, en esa acelerada sobreadaptación, se deja entrever una más que peligrosa desatención a las transformaciones socio-culturales que como consecuencia, y paralelamente, ha producido y producirá el desarrollo tecnológico o, como se dice programáticamente, el diseño y construcción de la sociedad del conocimiento y la información.

En la actualidad la institución universitaria española se encuentra en un proceso de convergencia europea, por tanto, de afinidad y consolidación de una idea de universidad europea que propicia, como necesario, y condición primera, un replanteo de la idea de universidad. En el año 2010, asistimos a la integración del sistema universitario español en el espacio europeo de enseñanza superior (documento marco, febrero 2002): la adaptación de las enseñanzas y titulaciones universitarias deberían quedar diseñadas según unos perfiles profesionales que integrarían competencias genéricas, transversales y específicas (conocimientos, capacidades y habilidades) en el ámbito científico, técnico y artístico, que no sólo armonizarán con las titulaciones consolidadas de otros países, sino que contarán con la colaboración de responsables académicos, asociaciones y colegios profesionales.

La configuración institucional de las disciplinas, la orientación y competencias que hoy ofrecen las titulaciones, parten, en principio, de un enfoque que no puede eludir los modelos de universidad que en el «Plan de calidad de las universidades» se definen como "de la calidad del producto —eficacia - y de la economía de la producción - eficiencia-". Plan de calidad de las universidades en el que se define la calidad universitaria a través de los siguientes modelos: a) el modelo de producción industrial 
[transformación de los inputs (alumnos) en outputs (graduados)], y b) el modelo de desarrollo global [estaría determinado por el valor añadido del desarrollo personal (un término evidentemente impreciso para la institución como parámetro para una posible evaluación)]. Parece obvio que la cuestión de la calidad (del valor) continuará siendo determinada a partir de formulaciones numéricas, a partir de formulaciones polinómicas: número, grupo o tendencia, que según la ley de mercado resulta más o menos rentable.

Sin embargo, por otro lado y al parecer de manera contradictoria, en un documento elaborado por la comisión de las Comunidades Europeas ${ }^{52}$ se dice: "La universidad detenta la clave de la economía y de la sociedad del conocimiento desde numerosos puntos de vista" y debe enfrentarse a nuevos desafíos, que se agrupan en cinco grandes categorías: El aumento de la demanda de formación superior, la internacionalización de la educación y la investigación, desarrollar una cooperación estrecha y eficaz entre las universidades y la industria, la multiplicación de los lugares de producción de conocimientos, la reorganización de los conocimientos y la aparición de nuevas expectativas. La lectura de estos documentos de naturaleza institucional, deberían reactivar nuestra 'responsabilidad universitaria' no como un concepto más sobre el que teorizar, sino como un nuevo paradigma donde lo intelectual, lo personal y lo político, en su complejidad, definen la tarea de pensar el presente como un nuevo territorio del, y para el aprendizaje, como una zona liminar que retoma la idea de las responsabilidades cosmopolitas formuladas por Thiebaut, cuando propone:

"La idea de responsabilidad es, tal vez, lo que nos permite salir de la paradoja de no poder ver lo que no vemos en un momento dado, pues podemos definir algunas responsabilidades que tenemos aunque no tengamos todavía una noción clara (una visión clara) de los mecanismos institucionales (como los derechos) por los que definirlas." 53

52 «El papel de las universidades en la Europa del conocimiento». Comunicación de la comisión de las Comunidades Europeas, Bruselas, 5 de febrero de 2003.

53 THIEBAUT, C., Ibídem., pág. 63. 
La idea de responsabilidad debería proyectar sobre la comunidad universitaria cuestiones como (y respecto) a lo real globalizado, la complejidad de los mundos de vida, la percepción que como un espacio más se tiene de la universidad: como un espacio separado, escindido e incapaz de negociar con lo real. Un espacio necesitado de una franca noción de las ideas de compromiso y responsabilidad, de una trabajada alteridad.

\subsubsection{Imagen de la Universidad}

"Para pensar el mundo, para pensar la sociedad y para pensarnos a nosotros mismos hemos de adoptar la perspectiva del otro, de todo otro, con quien coordinemos nuestra acción." 54

Si revisamos la idea de universidad asumiendo estas premisas, tomando conciencia de nuestra responsabilidad ante el futuro, la tarea de la universidad y su devenir como institución se enmarcarían en un espacio móvil, de actividad liminar entre múltiples conflictos. La universidad actuaría desde el conflicto y en el lugar del conflicto [no hay idea de universidad sin cuestionamiento, sin vocación de cambio y transformación]. Quizás, como señala J. Hillis Miller, deberíamos tener una universidad del disenso, sabiendo que dicha redefinición no tendría lugar sin resistencia de la comunidad universitaria, a quien solicita una actitud paciente y una gran habilidad retórica para convencer a los nuevos gobernantes de la universidad.

Disenso, como noción, puede ser entendido de dos formas distintas que se podrían identificar con dos maneras de asumir la alteridad; el primero, podría ser un desacuerdo que a través del diálogo llega al entendimiento, donde el disenso aparece como un eslabón hacia el consenso, o bien, el disenso como una forma de alteridad radical que no permite alcanzar el acuerdo, que exige mayor nivel de comprensión y respeto, sabiendo que "cada acto de disenso recrea el yo de aquel que lo lleva a cabo"; en este sentido el disenso llevaría a la institución universitaria hacia un 
modelo performativo y aunque es difícil imaginar una universidad del disenso está sería como argumenta J. Hillis Miller: "el lugar de bienes irreconciliables $y$, hasta cierto punto, difíciles de entender de forma conjunta." 55

Este enfoque - posible imagen renovada de la universidad-, propiciaría [debería propiciar] un nuevo paradigma, y determinar un marco conceptual particularizado que nos ayudaría a comprender ciertos problemas [en la relación sociedad-universidad-cultura] que por su complejidad deben ser definidos o necesitan ser investigados a través de nuevos modos y métodos, entre los que habría un espacio para las nuevas humanidades, un espacio en la universidad del conocimiento.

"Una de las contribuciones más importantes de las Humanidades a la sociedad del conocimiento y la información es la preservación patrimonial, entendida no como una actuación museística, sino también interpretativa y de mediación, para transmitirla a la sociedad del presente. La investigación científica y los avances tecnológicos no se pueden concebir separados de la sociedad y de su bagaje histórico, sólo adquieren sentido si se entienden como productos culturales que conforman esa "segunda cultura"... Pues bien, la cultura humanística puede aportar mucho a la científicotecnológica, y no sólo a la sociedad en general."56 

Parte III

CUADRO DIDÁCTICO 



\section{CUADRO DIDÁCTICO}

"El poder de la igualdad es, al mismo tiempo, el de la dualidad y el de la comunidad. No existe inteligencia allí donde existe agregación, atadura de un espíritu a otro espiritu. Existe inteligencia allí donde cada uno actúa, cuenta lo que hace y da los medios para comprobar la realidad de su acción. La cosa común, colocada entre las dos inteligencias, es la prueba de esa igualdad, y eso con un título doble."

Jacques Rancière 


\subsection{EL INDIVIDUO EN EL ARTE}

Las consideraciones que intentaremos ofrecer no tienen nada de extraordinario (por difícil o polémico) en el plano estrictamente teórico pero sí creemos que tiene una función que cumplir (y reivindicar) a un nivel intersubjetivo, y tal como deduce nuestro interés -desde el comienzo mismo de nuestra investigación-, algo más próximo a lo corriente: a nivel domestico o, dicho de otro modo, de la prudencia y de lo común. Su función toma cuerpo en el intento de ordenar todo aquello [instrumental categorial y propiamente lingüístico] relativo al orden realizativo, funciones y usabilidad en el entorno, a los modos de hacer y las prácticas de orden simbólico. Para ser más precisos, en ese plano de lo intersubjetivo en el que relacionamos las prácticas domésticas con los modos de hacer y de las prácticas de orden simbólico, aquello que intentaremos considerar [armar la figura problema que la dibuja] y que de hecho ansiamos entre la plenitud en una profunda discusión, se encuentra mucho más difundido y su desajuste es más obvio de lo que imaginamos, como es la cuestión de la relación existente entre los términos "individuo y arte" y sumergida en ella, la también relación "individuo y práctica artística".

De lo que se trata es -como base para un posterior y profundo ensayo-, de reflexionar a través de la relación "individuo y arte" sobre la práctica al hacer la práctica, de dar visualidad a la cuestión de que al hacer la práctica (partiendo del supuesto de que toda actividad artística tiene una naturaleza sintáctica y así la base en el lenguaje y en el compromiso, y que por tanto tiene en la relación "individuo y arte" su fondo mismo), necesariamente han de hacerse visibles o explícitos los criterios de verdad que la sustentan, no ya desde el punto de vista de la difusión de la obra como tal, sino de su principio esencialmente gnoseológico, lo cual significaría la aceptación y hasta cierto punto el reconocimiento de que los enunciados propios de la labor del sujeto espectador, hacedor o artista (no sólo los referidos a las obras, puesto que la base de su articulación siempre descansa en premisas gnoseológicas, sino también 
todos los textos que en su conjunto producen) deberían, como alguna vez ha sostenido Roger Chartier ${ }^{1}$, ser sometidos a la discusión.

El individuo es el individuo

"El individuo es el individuo, pero en cuanto entra en contacto con la historia se convierte en un gran individuo creador de la historia o en un simple individuo aplastado por la historia. De este modo, la historia aparece bajo un aspecto diferente según se refiera al individuo histórico o al simple ser humano".

Con ésta afirmación Karel Kosik ${ }^{2}$ comienza su peculiar ensayo sobre la relación "historia e individuo" y curiosamente lo hace invirtiendo el orden que en el titulo da a cada término antes de la formulación de tres preguntas consideradas para él fundamentales para determinar la especificidad de la función que cada uno cumple en dicha relación. Es únicamente a partir de su afirmación sobre el modo de aparecer de la historia que Kosik puede formularse la pregunta del tipo "iSignifica esto que hay dos clases de historia, una para el individuo histórico y otra para el simple ser humano?", como de igual manera, y sólo a partir de la diferenciación histórica del individuo, puede formulársela en los términos de "¿Acaso el individuo sólo es autentico en la medida en que crea la historia y ésta no es auténtica más que en la medida en que aparece como resultado de la actividad de los individuos históricos?", o como para esa otra que sólo es posible darle formulación a través de la acentuación del poder de una exterioridad [de una opinión o estado de opinión] entonces condicionante al estilo de " ¿O bien es ésta una opinión externa y hay que creer más bien a los que ponen el acento sobre lo que el gran individuo y el simple individuo tienen en común y ven en la historia un proceso en el que todo el mundo participa y que permite hacer valer las aptitudes de cada cual?".

En nuestra consideración la relación 'individuo y arte' parece evidente; sin embargo el modo de conocerla se nos muestra, en apariencia, complejo: acaso el hecho de conocer qué es el arte nos garantiza o deduce que conocemos qué es el individuo en esta relación o

I Conversación con Roger Chartier. URL: http:/ / tinyurl.com/mybtkja [Fecha de consulta: 18 de febrero de 2010]

2 KosiK, KARel. Historia e individuo. Ed. Almagesto, Buenos Aires, 1991. Pág. 5. 
el grado de dependencia de uno respecto al otro. El acercamiento a la operatividad de ambas nociones supone que el 'individuo' y el 'arte' son categorías cuya dependencia no es para nada de subordinación, una no depende de la otra. La primera (propia de la modernidad) entendida antropológicamente es inseparable de nociones como sociedad, masa, gente, multitud y persona; la segunda, entendida como actividad (actividad o producción realizada por el ser humano con una finalidad comunicativa y estética) es de algún modo resultado de una consideración cuya potencia contextual (la nitidez de los límites operacionales de la ordenación cognitiva y simbólica) es la que permite discernir el núcleo central de la práctica. Sin embargo, ambos conceptos suelen expresarse mediante concepciones contradictorias: ambas expresadas en la distinción de Karel Kosik -donde una "afirma que los grandes individuos crean la historia", y la otra, "que la historia toma forma a partir de fuerzas supraindividuales" propia del "espíritu universal" hegeliano (de la razón universal dada como entidad a través del conjunto de las vidas, de las ideas y de la cultura de los seres humanos, a través de la Historia). En ese mismo sentido, la expresión común del arte hace en los mismos términos la historia (de forma contradictoria): una sobre la creencia de que son los grandes artistas los que crean el arte trascendental y mayúsculo, y además crean su historia; otra, bajo la influencias de la "razón universal" defendida por Hegel; y una tercera, propia de la circunstancialidad, que cree ver la potencia de expresión del arte en un juego mixto de roles, donde el gran individuo artista conserva la capacidad trascendental de modificar la historia aunque a través de fuerzas disciplinares específicas (son los modos disciplinares los que confieren valor reivindicativo y de arma a la actividad, es por ello que escuchamos expresiones al estilo de "la imagen como herramienta política", etc.), en cuya abstracción se encuentran unas fuerzas productivas siempre indefinidas, propias de las posiciones vulgarizadas del marxismo.

En este punto es destacable el grado de coincidencia y de interpretación mutua de las tres posiciones sobre todo en la consideración de que la práctica artística (la creación, por tanto con acento y aún potencia teológica) es un privilegio otorgado, o que 
no se otorga más que a algunos agentes elegidos, a los "grandes individuos" o, con palabras de Kosik, a "abstracciones hipostasiadas", o como diría Gustavo Bueno: "Hay razones y motivos, ya sean ideológicometafísicos ("lo universal es lo efectivamente real y permanente", o bien, "lo individual, el hombre de carne y hueso, es el unico lugar en donde vive la realidad intrahistórica"), ya sean ideológico-politicos". 3). Al respecto de estas coincidencias, Kosik, argumenta:

"Según uno de estos puntos de vista, para que el hombre pueda intervenir en la historia debe distinguirse no sólo de los simples individuos, sino también de los que persiguen el mismo fin, es decir, de los que quieren hacer historia, y su grandeza histórica estará en función del grado de diferenciación que haya alcanzado."4

De forma similar a la división en dos categorías que se producen en la perspectiva del gran individuo de la historia, se produce en la perspectiva del gran individuo del arte: la primera (el conjunto de los otros individuos, entendidos como observadores) constituyen la materia de la actividad en tanto que sólo figuran como objetos centrales de conocimiento y de la historia de la actividad; la segunda, es propia, porque los acoge, de los individuos artista que aspiran a un papel histórico, "por lo que cada uno se convierte en enemigo potencial del otro", de tal modo que este individuo artista se hace histórico, del mismo modo que el gran individuo, "en la medida en que su actividad particular tiene un carácter general, es decir, en la medida en que de su acción se desprenden consecuencias generales". Esto deduce, desde el supuesto de la continuidad de la historia, que el papel histórico de dicho individuo puede o no tener lugar en dependencia de que en el período dado haya más o menos grandes individuos, y por lo mismo que su historia puede o no desaparecer.

Al respecto de esta significación Gustavo Bueno, aclara en su redefinición gnoseológica del significado del individuo en la Historia: "Cuando el profesor Seco, por ejemplo, nos dice-siguiendo a Jesús Pabón-que hay dos modos de aproximarse, mediante la biografía, al individuo histórico,

3 Bueno, Gustavo. El individuo en la historia. Oviedo, Octubre 1980. Pág.15

4 KOSIK, KAREL. Historia e individuo. Ed. Almagesto, Buenos Aires, 1991. Pág. 7. 
a saber, trazando la vida del personaje desde dentro, o bien trazándola por líneas exteriores, nada se nos está aclarando gnoseológicamente, sino que, por el contrario se nos está confundiendo, al creer ingenuamente que se dice algo con la contraposición dentro/fuera (14). Porque la distinción dentro/fuera es una distinción metafísica en el momento en que consideremos al mentalismo, no ya como meta inacesible, sino método vacío, simple "modo material de hablar". En todo caso, y aunque a eso que Gustavo Bueno, desde su análisis basado en el método del cierre categorial, llama 'significado del individuo en la historia', y que Kosik parece ver en su relación individuo e historia a través de la crítica a la figura del gran individuo (propia de la división interpretativa en cuanto al papel histórico del individuo), a nosotros nos interesa la afirmación de éste último -porque contiene, en cierto modo el sustrato filosófico del primero- en relación a esa contradictoria función significante de la noción de gran individuo:

"Si la actividad de los grandes individuos no se inscribe en una cierta continuidad del proceso y no es cocreadora de esta continuidad, ya no hay historia y en su lugar se instaura un caos hecho de acciones aisladas e incoherentes. Si se admite una continuidad histórica, ésta resulta, según esta concepción, de la actividad de los grandes individuos confrontada con la generalidad de la historia. El gran individuo puede negar de palabra esta generalización, lo que no le impide existir ni depender de ella, ni reconocerla y convertirse en su representante consciente. A partir de este instante el individuo presenta su actividad particular como una manifestación directa de lo universal: es la historia misma la que se realiza en sus actos, es el Ser mismo el que se expresa a través de sus palabras. El gran individuo, que intervenía al principio como creador de la historia, se convierte ahora en instrumento de la historia." 5

De lo que se trata, tanto desde la postura crítica de Gustavo Bueno en relación al 'significado del individuo en la historia' como desde la también crítica del 'gran individúo histórico', de Karel Kosik, es

5 коsıк, к., Ibídem., pág 8. 
de que en ambas figuras observacionales del individuo y su papel en la historia se da como contradicción (la misma contradicción), o mejor dicho toma forma, un cierto autologismo ${ }^{6}$, en el sentido de que ambas en su proyección de/y ante la historia deciden construir (dar a priori) una experiencia pasada significativa, un presente de significación equivalente o superior a la pasada, y un porvenir que presupone en los dos estados cualitativos anteriores una plena significación histórica. Dicho autologismo es tan evidente que, quien lo práctica (gran individuo) no puede menos que saber que lo que está haciendo es una reconstrucción de él mismo, "bajo la forma de otro que, al ser yo mismo, tendrá que ser determinado como diferente para que pueda figurar como sujeto histórico"7, y por otro lado, es al menos contradictorio porque el tiempo del gran individuo (artista) es el tiempo interno del propio proceso histórico que vive -un tiempo difícilmente reconocible a la par que la vivencia está teniendo lugar- por cuya voluntad él quiere alterarlo dotándolo de significación (del cual la temporalidad astronómica es sólo una medida y no aquello que lo dotaría de carácter histórico como es la distancia).

Es por ello que a lo que nos oponemos no es que un individuo proclame la voluntad de trabajar o empeñar su esfuerzo con tal de convertirse en alguien importante, sino a que el individuo entienda ya como importante, en términos histórico, aquello futuro en la mismidad del hoy presente (claro que sin negar que pueda serlo al cabo del tiempo). Es que el arte sólo lo es en relación a la historia, y -aunque como ámbito no cerrado del conocimiento y del orden simbólico-, se interesa por los actos, los procesos y las obras cuya articulación (la de la apertura de su función de significación) está siempre acabada, terminada, por, o en el acontecimiento o pauta inicial que en relación a ellas ha tenido lugar.

La necesidad que en este caso el artista introduce o decide para sí (necesidad hegeliana), es de automixtificación, mixtificadora pues introduce una apariencia de unidad o de orden allí donde sólo hay contradicciones y desajustes gnoseológicos, disimula la magnitud de

6 Ibídem., Pág. 68. “... decimos que reconstruimos la experiencia pasada cuando ya la hemos dado por presupuesta."

7 Ibídem., pág. 68. 
significación de su papel como individuo identificando el juego (el papel de individuo histórico) como algo convenido a priori, cual si ya el porvenir le hubiera sido otorgado, de modo que el drama mismo de lo producido por él en el conjunto de la historia que se articula no es una necesidad propia del acto histórico tal cual, sino el acto en el que tiene lugar la interpretación tanto de la necesidad como de su contingencia en el que el resto de los individuos e incluso el paisaje marco que lo acoge no son para nada elementos de la necesidad y si factores (de mixtificación o de desmixtificación) cuyo papel en el desenlace de lo histórico no cumple ningún cometido.

Sin embargo, en nuestra relación al individuo le queda algo por hacer no ya en conexión con el arte sino desde el arte mismo, y lo puede a partir de todo aquello antes excluido en la antinomia tanto individuo y arte, como individuo e historia; a partir de todo aquello que lo reduce a simple objeto de la reificación (como vaciamiento de todo contenido humano de la historia); a partir de los momentos existenciales de la praxis humana, como la risa, la alegría, el miedo y todas las formas de la vida en común cotidianas y concretas, como la amistad, el honor, el amor, la poesía; como todos los apartados de las acciones y acontecimientos históricos en tanto que asuntos privados, individuales o subjetivos, convirtiéndolos en simples instrumentos funcionales, para hacer de ello todo lo contrario de lo que desde los principios antinómicos históricamente se ha convenido hacer que es convertirlos en objetos de una manipulación (manipulación que abarca desde el honor hasta la valentía).

Viaje de los conceptos y categorías al plano mismo de lo realizativo y lo doméstico.

Por un lado, actualmente el problema antropológico constituye el centro de la reflexión de orden filosófico porque nunca antes, como en este momento, el hombre se había preguntado tanto sobre sí mismo en relación al mundo de las cosas. Por otro lado, y sin precedente alguno en la historia de la humanidad -diríamos que como un efecto derivativo e interesado del desarrollo mismo de la nuevas tecnologías de comunicación y como es obvio de las prácticas de análisis 
interdisciplinar-, se ha producido el viaje $\mathrm{e}^{8}$ (cada vez más intenso) de los conceptos y categorías propios de las ciencias y la filosofía al plano mismo de lo realizativo y lo domestico. El más notable y no menos complejo de esos viajes ha tenido lugar en las humanidades 9 dando lugar a eso que Mieke Bal ha llamado "problema del análisis cultural interdisciplinar" y que para nosotros tiene su origen no sólo en la incertidumbre propia del cruzamiento de los ámbitos propios de los conceptos sino sobre todo en el asentamiento inconsistente de éstos en el plano doméstico, en el plano de lo propiamente realizativo y por lo tanto, en el de las prácticas y los modos de hacer. La recompensa de una nueva experiencia siempre se produce como resultado del viaje de unas cosas o de unos estados a otros; sin embargo no siempre la "nueva experiencia" es sinónimo o debe reducirse a "cualitativamente mejor".

En el caso de los conceptos, el viaje que de ellos puede producirse o que se ha producido, deberíamos entenderlo en el plano de su usabilidad (tal viaje tiene por carácter un sentido utilitario y eminentemente práctico). En términos teóricos o en los modos de hablar el viaje al que se someten los conceptos nunca es accidental sino intencional y por lo tanto, su viajar esta sometido a un conjunto de condiciones de índole práctica. Así que si dicho concepto no encuentra en el nuevo ámbito sintáctico una significación funcional lógica, su viaje hacia la práctica es (o será) transitoriamente infructuoso.

Nociones como individuo (propio de la modernidad) y persona (nombre femenino de origen latino, que expresa en su interpretación filosófica, en tanto que es propio de la filosofía, aquello singular de cada individuo de la especie humana en contraposición a 'lo que en ellos hay de común' entonces expresado por el concepto también filosófico de "naturaleza") ya no constituyen en el marco de su usabilidad coloquial meras palabras, términos (o nombres coloquiales), puesto que la fruición propia de su viaje desde la filosofía o los juegos de lenguajes propios de la modernidad los ha alterado (bien amplificándolos o bien

8 BAL, MIEKE. Conceptos viajeros en las humanidades: Guía de un viaje. Ed. CENDEAC, 2009. Colección “Ad Litteram" dirigida por Miguel Ángel Hernández-Navarro y Yaiza Hernández Velázquez. Murcia.

9 Ibídem., pág. 10. 
restringiéndolos) en relación con sus nuevos ámbitos de usabilidad y de análisis como pueden ser los de las prácticas políticas, las prácticas artísticas, las prácticas deportivas, administrativas, etc., y además, puesto que ya no son recursos meramente expresivos y del habla, sino más bien herramientas de socialización, en tanto que su tratamiento de significación, proyección y comprensión intersubjetiva, se produce (de manera extendida) en términos políticos o de teorías en miniaturas ${ }^{10}$, y por lo mismo -desde una perspectiva distinta- gnoseológicamente en relación con "masa" y "gente". El uso extendido de la noción individuo no sólo se limita al nombramiento de la cosa, sino a facilitar el análisis de su relación con las situaciones, los objetos, los estados y con otras teorías. ${ }^{11}$

$\mathrm{Al}$ respecto de la cuestión del individuo, Gustavo Bueno (1980) en el análisis de "La primera Vía (la vía aristotélica)" describe la respuesta de Aristóteles a la pregunta sobre el fundamento gnoseológico de la noción de individuo en relación a la historia: "el individuo se dice de muchas maneras"; por ejemplo, no sólo de individuo sustancial, sino también de una acción (de un "evento") o de "una serie de acciones en un lapso de tiempo"12. Aunque después de decirlo vuelve a referir las acciones a los individuos sustanciales: "Todo lo que en tal lapso de tiempo pasó a uno o a muchos hombre".

Ahora bien nuestra consideración plantea la discusión de la relación "individuo - arte" basado en el supuesto de que la lógica interna de tal relación es gnoseológicamente fundamental para el entendimiento

10 "El artículo de Culler, que sigue la trayectoria del concepto de lo performativo, viaja en primer lugar entre la filosofía (donde el concepto se utilizó por primera vez) y la literatura (donde sirvió para resolver problemas importantes enfrentándose además a las limitaciones de la propuesta filosófica); después regresa de nuevo a la filosofía y desde allí parte hacia los estudios culturales para volver otra vez a la filosofía." Cita utilizada por Mieke Bal, pertenece a Jonathan Culler, publicada en "Philosophy and Literature, The Fortunes of the Performative", Poetics Today 21 (3), 2000, pp. 48-67.

11 Usamos el término en el sentido que Mieke Bal le confiere en Conceptos viajeros en las humanidades: guía de un viaje, cuando dice: "Si pensamos lo suficiente sobre ellos, nos ofrecen teorías en miniaturas y, de esta guisa, facilitan el análisis de objetos, de situaciones, de estados de otras teorías". Ibídem, pág. 35

12 Artículo Segundo: Exposición crítica de las cuatro opciones que envuelven a la resolución aristotélica. Pág. 17. 
(como facultad receptiva, que refleja, como un espejo, la realidad, sin alterarla) y para la voluntad (como facultad práctica, orientada a modificar la realidad, ya sea en el sentido de la poiesis -regulada por la techné (arte)- ya sea en el sentido de la praxis -regulada por la phronesis (prudencia)-, no sólo proyectada hacia los modelos de prácticas derivados de la actividad del autor en relación al modelo sociohistórico, sino sobre todo en la comprensión de su papel (en el sentido de la necesidad de la intervención previa del entendimiento-saber para mover a la voluntad operacional o del "entendimiento práctico"13 o "preparación de la intervención de la voluntad") en la constitucionalidad del giro arte también en relación con el papel del lenguaje como esencial en la potenciación productiva del sujeto artista, ya sea a niveles de tipo instrumental, de tipo metodológico, de tipo técnico o de tipo categorial.

A grandes rasgos esto es: que el entendimiento teórico condiciona, en tanto que siempre tiene que ajustarse a los principios derivados de las formas a priori (al objeto o proceso) para consolidarse -bien porque a su través constituye el instrumental analítico- como análisis y por lo tanto como teoría, pero siempre y cuando ello «engrane» con materiales empíricos, la comprensión más o menos intensa del objeto o cuestión dispuesta en el radio artístico de la reflexión. En torno a la idea de naturaleza y de universo, así como a la idea de hombre y de individuo, parece haberse conservado un cierto matiz metafísico heredado de la representación de la filosofía, visible (en su momento) en el ámbito de las ciencias sociales a través de las tensiones dentro de sus campos disciplinares, como por ejemplo en la antropología, la sociología y posteriormente, la historia a cuyos registros empíricos del individuo en relación con los hechos sociales era antepuesto [se ponía frente a ellos], de algún modo, la apercepción trascendental ${ }^{14}$, o, en términos de

13 Aristóteles, Pó́ticA.

14 BUeno, gustavo. "Confrontación de doce tesis características del sistema del Idealismo trascendental con las correspondientes tesis del Materialismo filosófico". Ed. Revista El Basilisco, $2^{\mathrm{a}}$ época, $\mathrm{n}^{\circ}$ 35, 2004, páginas 3-40. (Revista de filosofía, ciencias humanas, teoría de la ciencia y de la cultura) http://filosofia.org/rev/bas/bas23501.htm [Fecha de Consulta: 12 de marzo de 2012]

"De este modo, la oposición especulativo/práctico se introducía en el mismo entendimiento, que unas veces permanecería (como entendimiento especulativo) en la pura inmanencia de su ejercicio 
la teoría del conocimiento [y como formulación resultado -'Critica de la razón pura', publicada en 1781 - del intento de superar las limitaciones propias del racionalismo] del sujeto trascendental kantiano.

Uso extendido de la noción de individuo.

¿Qué quiere decir eso de uso extendido de la noción de individuo? Quiere decir, en términos de entendimiento intersubjetivo, que individuo parece ser - de cara a su usabilidad en la actividad vivida y en el modo de hablar- un concepto explícito (que se expresa con claridad y que al parecer está especificado de forma clara o detallada), de modo que todos podemos adaptarlo y utilizarlo según la nitidez y también transparencia de nuestro marco de actuación. Esto es, si la definición de marco de actuación no está del todo definida, la solicitud de facilitador del análisis que al concepto en cuestión le hacemos, no tiene (porque no cumple el conjunto sistemático de sus distinciones ${ }^{15}$ ) efecto representacional alguno. Pero del mismo modo, aun estando definida la nitidez y transparencia del marco de actuación, si ese carácter de explícito no es del todo preciso (su qué es hasta el último detalle), la usabilidad de la noción de individuo perdería su eficacia por carecer y no poder entonces ejercer en la especificidad del marco en cuestión su potencia de sentido.

Ahora bien, nuestro esfuerzo en torno a la noción de individuo sólo tiene interés si en el contexto de esta investigación se le relaciona con el arte, y consiguientemente con un momento y con una nítida

(como una practicidad inmanente, una "práctica teórica», se dirá siglos después, como sabiduría entendimiento de los principios o ciencia teórica). Y otras veces como entendimiento práctico, preparando la intervención de la voluntad (a través de la sindéresis, de la prudencia o del arte). La técnica, según esto, se concebiría como una aplicación de los principios teóricos: la Agrimensura sería la parte práctica de la Geometría teórica. La voluntad práctica, por su lado, quedaría dispuesta cuando adquiriese los hábitos virtuosos de la prudencia -eslabón entre el entendimiento práctico y la voluntad-, la templanza, la fortaleza y la justicia."

15 "En virtud de nuestro estado, la conciencia del yo en la percepción interna es meramente empírica, siempre mudable, sin poder suministrar un yo fijo y permanente en medio de esa corriente de fenómenos internos. Dicha conciencia suele llamarse sentido interno apercepción empírica. Lo que necesariamente tiene que ser representado como numéricamente idéntico no puede ser pensado como tal a través de los datos empíricos. Anteriormente a toda experiencia, ha de haber una condición que haga posible esa misma experiencia y que dé validez a tal suposición trascendental". En "Crítica de la razón pura", A-107. 
especificidad histórica. Nos interesa en relación con el arte en sí y no fuera de ese ámbito. Pero ¿qué define eso del "arte en sí? ¿A que nos referimos y qué queremos decir con ello? Arte, como comúnmente se sabe, es un concepto. Sin embargo, presuponerlo como tal, como un concepto, deduce o al menos debería tender a ello una cierta aproximación a Idea, y de hecho, a una complejidad genérica de semejantes, parecidos u homólogos, derivada del estudio de ejemplos prácticos y teóricos particulares; a decir, una "idea general que abarca a varias cosas parecidas ${ }^{\prime 16}$ en tanto que herramienta de intersubjetividad en el ámbito de los modos de hacer de orden simbólicos. El arte por tanto no es [no debería así ser entendido] su historia, pero tampoco es el arte aquello en su filosofía (aunque la intrincación entre historia y filosofía en relación con el arte suscriba una cierta tensión que podría ser pensada (¿por qué no como una cuestión gnoseológica?) como sistémica. En definitiva nos interesa tratar la noción de individuo en relación doblemente con Arte y con Idea. Con arte y con idea, entendido ambos inicialmente como conceptos. Lo que queremos poner en discusión es si las construcciones históricas que se escriben y otorgan a los artistas según un modelo de prácticas artísticas, podría ser escritas del mismo modo y en lo esencial, si sus sujetos protagonistas hubieran sido otros o estado en lugares distintos a aquellos donde han ocurrido las cosas, así como la importancia y papel gnoseológico del individuo en los procesos formativos artísticos y de las producciones de orden simbólicas.

Gustavo Bueno en "El individuo en la Historia ${ }^{17 "}$ para introducirnos en los conceptos de lo individual y del individuo y su papel en la historia, antes expone una serie de consideraciones sobre el análisis formal $^{18}$ presupuesto según su modo sui generis de entender la generalidad de la lógica formal como aplicable a campos no científicos, de las que concluye:

16 Ibídem., pág.36

17 Esta definición es un fragmento de "... idea que abarca varias cosas parecidas, derivadas del estudio de ejemplos particulares.. Sinónimo: véase IDEA", la definición del Longman Dictionay of the English Language (1991).

18 BUENo, GUSTAVo. Ibídem. 
"... ocurre que precisamente aquello que llamamos "análisis lógico-formal" tiene mucho que ver con el mismo concepto de lo individual, precisamente en cuanto se opone a lo universal, más aún: a nuestro juicio es una cierta manera de entender el individuo -en relación con lo universal-aquello que precisamente define el nivel lógico formal del análisis."19

Aquello que define el nivel lógico formal ${ }^{20}$ del análisis es lo que hace precisamente entendible el individuo (extensible de algún modo el límite que de él tenemos), por cuanto tiene que ver más con lo universal [con la universalidad distributiva, y por consiguiente, en oposición a los individuos distributivos, puesto que sólo significa algo en función de ellos,] que con lo general. Las universalidades distributivas siendo totalidades diariológicas sólo significan algo respecto de sus partes lógicas, o sea, de los individuos enclasados en ellas. Por ejemplo, del análisis de la relación arte-artistas, arte tiene que ver de algún modo con lo universal y en función de ello debe ser entendida como una universalidad distributiva que sólo se cumple como significado en función de sus partes lógicas, a saber, de los individuos distributivos $o$ individuos enclasados ${ }^{21}$ (artistas) que conforman dicha universalidad, siendo la tarea de artistas (como individuos enclasados) la de hacer de "función proposicional".

Así, aquello que vale para una de las partes vale igualmente para todas ellas, produciendo una especie tautología en tanto que esa validez está ya siendo interpretada en la relación inicial como una parte cualquiera de la clase (como un individuo enclasado más de la clase arte). Ahora bien, respecto a la consideración de "eso que define el nivel lógico formal del análisis en relación al entendimiento del individuo", de lo que se trata es de atender -organizar las más diversas cuestiones- al conjunto metodológico y categorial propio del problema (individuo)

19 "... presuponemos un "modo sui generis" de enteder la generalidad de la lógica formal como generalidad que, in recto, cuanto a contenido, es material (especial) y que sólo es general (es decir, aplicable incluso a campos no científicos) in obliquo." en Bueno, Gustavo. "El individuo en la Historia". Ibídem.

20 Ibídem., pág.10.

21 Gustavo Bueno cuando se refiere a la aplicabilidad de los análisis formales se refiere tanto a la "logica formal aristotélica como a la lógica formal de nuestros días, llamada "lógica simbólica". 
como decisivo, en tanto que como recurso es necesariamente derivativo de la clase significada como problemática, y, en consecuencia, también de los individuos enclasado, como problema. Es la perspectiva analítica -el instrumental construido para ellas- la que moldea de algún manera el cuerpo teorético el problema: es la que moldea (en tanto que exposición crítica) la teoría; de modo que para que individuo sea entendido, debemos abandonar la postura lógico formal (considerada antes de forma básica, y resituarnos a escala de las condiciones teoréticas propias (la propia del análisis del individuo).

Lo individual en el arte se dice de muchas maneras porque el arte en sí es cosa perecedera (elástica, siendo como es esencial su punto de partida gnoseológico que en apariencia, y sólo en apariencia, se disipa en la obra), que no se repite en tanto ignora -en el sentido de su socialidad y para razonar sobre lo que es de algún modo universal- el acontecimiento histórico. Del mismo modo que la universalidad histórica no puede definirse como total porque esa universalidad total nunca esta dada, la universalidad artística tampoco puede definirse como total porque no está nunca dada como totalidad. En todo caso, lo de el arte como un universal total sólo tiene lugar para Dios, y por lo mismo es una apreciación teológica intencional ${ }^{22}$ (el individuo absorbido por el creador y disuelto en la creación) instaurada como una vulgarización en el modo de hablar común occidental, expresiones viajeras, diría Mieke Bal.

Cuando se habla de arte -en sentido mayúsculo o, si se quiere, trascendental- de lo que se trata, o más bien lo que expresa el término, es de aquello consustancial a los humanos, común (como posibilidad) a todos los humanos en el orden de la producción de simbolicidad. En ese sentido arte no hace referencia ni a los modos de práctica, ni al valor, ni a los artistas productores de obras y menos a sus formas de historización sorprendentemente aún teologizadas, sino a la consustancialidad en el plano gnoseológico, a decir: de aquello otro por lo que los humanos

22 El uso que Gustavo Bueno le da en "El individuo en la Historia", proviene del concepto "clase", del que dice: "El concepto de clase, en cuanto multiplicidad de elementos que coinciden en una definición (o conjunto de notas intecionales) es universal (extensional), en este sentido". Ibídem., p. 10. 
pueden ser conocidos y de aquello otro que de los humanos puede conocerse, pero no de su especificidad, que ya concierne a los individuos $\mathrm{y}$ a sus producciones.

El arte siempre ha sido, y no sólo en la actualidad como ha llegado a creerse, un fenómeno de múltiples formas y de diversas manifestaciones. Es ahí donde radica su potencia. Ahora bien el arte tiene una connotación negativa cuando se le observa desde una sola posición, cuando no se le acepta perecedero y elástico. Así cuando Tzvetan Todorov expresa "El arte es parte importante de la sociedad en general y del individuo en particular", lo hace como sabemos en un plano coloquial [y político por la especificidad circunstancial] pero desde una generalización insalvable en tanto, da por supuesto una unidad casi orgánica entre la clase distributiva, que es en este caso arte, y el individuo enclasado, que en todo caso lo constituyen bien los modos de hacer y de prácticas, o bien los artistas o señores conscientes de su enclasamiento. Generalización insalvable por cuanto Tzvetan Todorov no separa las potencias gnoseológicas y funcionales de cada ámbito: como sí ambas cosas cumplimentaran las mismas funciones, al respecto, de esa especie de universalidad extensional o denotativa, que Gustavo Bueno denuncia en "El individuo en la Historia" (1980).

Así lo universal referido o pensado a la par que la obra tiene una potencia de proyección teológica (en el sentido sagrado) de una creación total y por tanto proveniente de una conexión con Dios, y no en cuanto caso elegido, racionalmente construido, por ser o tener un cierto interés desde el punto de vista gnoseológico, o de algún modo por ser (o desde) el conjunto de operaciones y relaciones propias de la obra. En todo caso esto se nos muestra cuando dejamos de reducir el pensamiento sobre los procesos artísticos y de producción de simbolicidad a premisas de orden histórico y nos introducimos en un plano (previo al proposicional) en el que hay tiempos, términos, relaciones y operaciones procesales, tanto abiertas como cerradas, en las que como es evidente también funciona el individuo.

Resulta que todo elemento que entra en el proceso de articulación tanto de la obra como de la idea de la obra no deja de estar contribuyendo operativamente, porque aún utilizado como término 
lingüístico -cuando habla de lo que en él ocurre o de lo que en relación a él puede ocurrir- no deja de ser utilizado como un operador (como un operador, dicho en el sentido utilizado por Aristóteles según su percepción de la Historia de Heródoto -de Tucídides o de Platón-, de prudencia en cuanto al tipo de acción que versa sobre lo contingente), porque se da en el contexto de la individualidad operativa -de su intimidad relacional. Así, la obra, y no el arte, se ocupa operativamente de lo individual y lo contingente porque su ocupación tiene lugar y se produce en el campo mismo de la prudencia.

El hecho de que un elemento pueda ser insertado en el proceso de articulación de la obra sólo puede tener lugar si antes dicho elemento ha sido significado: o sea, si antes han sido potenciados de él su peculiaridad y su carácter; o dicho de otro modo, el elemento puede ser insertado en el proceso de articulación porque antes ha sido gnoseológicamente individualizado como operacional; se descarta así la posibilidad de que dicho elemento pueda llegar a ser pensado como una universalidad o generalidad que lo equipararía de raso tanto al campo (que construye para sí su instrumental y sistema de análisis) como al ámbito (entonces con un carácter funcional de receptor de vecindario, ${ }^{23} \mathrm{y}$ por lo tanto también de universalidades), así como a la propia clase que le da acogida distributiva.

Así como desde el arte se pretende entender (explicársela, darle proyección y tratamiento) a la obra como un universal, las prácticas o modos de hacer la tratan como individualidades, como individualidades gnoseológicas entendidas en el mismo sentido en que desde una perspectiva analítico-formal (según la resolución aristotélica ${ }^{24}$, por cuanto se descomponen en dos proposiciones, supuestos o hipótesis, que a la vez son antítesis, y que por lo mismo no pueden ser

23 Tzvetan Todorov en "Tzvetan Todorov: "Sin arte y sin artistas estaríamos perdidos". Entrevista de Javier López Iglesias publicada en www.hoyesarte.com. Sábado, 25 de septiembre de 2010. http://www.analitica.com/va/arte/oya/8776461.asp [Fecha de consulta: 29 de septiembre de 2010]

24 El ámbito tiene un carácter de receptor de vecindario de universalidades en tanto que acoge al conjunto de las clases con proyección operacional dentro de unos límites disciplinares y una estructura de análisis. A decir, el ámbito no lo decide la relación entre estructura de análisis y los límites disciplinares. 
desconocidas en el momento de fijar los significados) se aplica el análisis a las situaciones materiales de tipo gnoseológico; tipos gnoseológicos como: 1) El arte abarca lo universal y 2) Las prácticas o modos de hacer, tratan de individualidades (en el sentido de su especificidad también gnoseológica, y en cuanto a procesos especulativos cuyo desenvolvimiento tiene lugar en un mundo proyectante de esencias universales, como por ejemplo: El "mundo de la ciudad", al que se refiere Gustavo Bueno, en el que tienen lugar los procesos prácticos, prudenciales e individuales, en la medida en que dependen de la "razón práctica"). ${ }^{25}$ Thomas MacEvilley, dedica un capítulo -titulado

"Patas arriba y hecho trizas"- al estudio de lo sublime, claro está, en el discurso occidental. Su reflexión comienza con la siguiente cita: "Todo los demás atributos prueban que sus poseedores son hombres, pero la sublimidad eleva a uno adonde está cerca de la majestuosa mente de Dios"26. La cita expuesta proviene del tratado Perì hypsous, un extenso texto que data del siglo I d.C. que se atribuye a «Longino» o Pseudo-Longino, por no haber datos certeros que lo confirmen, cuya traducción viene a decir aproximadamente algo así como "Sobre lo sublime". De la relación de éste primer tratado con el concepto de lo sublime MacEvilley puntualiza:

"No es el librito de "Longino» el texto en el que por primera vez se trató del concepto de lo sublime, pues «Longino» dice que partía de sus estudios del «pequeño tratado de Cecilio sobre lo sublime». Éste es no obstante el texto que actualmente pasa por el comienzo del discurso sobre lo sublime -el Ur-text-,

25 Ibídem., pág. 12. "Al analizar la resolución aristotélica del texto de la Poética que nos ocupa desde una perspectiva analítico-formal (priorística) ella queda descompuesta de inmediato en estas dos proposiciones o, si se prefiere, en estos dos supuestos o hipótesis que, aunque formales por su estructura, se aplican a situaciones materiales de tipo gnoseológico..." "Evidentemente, para poder extraer de estos dos supuestos la conclusión que extrae Aristóteles en la Poética (la historia no es ciencia, o es menos filosófica o científica que la poesía) es conveniente interpretar los supuestos formulados en un sentido más exclusivo que asertivo (la ciencia se ocupa de lo universal, pero también de lo individual; la Historia se ocupa de lo individual, pero también de lo universal)."

26 Ibídem., p. 26. "Un mundo distinto de aquel, por tanto, en el que tienen lugar los procesos prácticos, prudenciales, individuales; es decir, el mundo de la ciudad, en la medida en que depende de él mismo, de la razón práctica, y aún de los silogismos prácticos, o sea, de la prudencia monástica, económica o política (que se ejercitan a la misma escala en la que se ejercitan los acontecimientos que relata la Historia)". 
y a él debe su estatus canónico en la tradición. "Longino» no sólo inicia la conversación sobre lo sublime, sino asimismo en la dicotomía entre lo sublime y lo bello, que perduró como armazón del discurso hasta Edmund Burke e Immanuel Kant".

Uno de los principios de reflexión que colateralmente cobró importancia en relación también al arte y el lugar del individuo entorno suyo -principios de reflexión relativo entonces al ámbito de las ciencias sociales en contra de la filosofía de la conciencia y que hallaron respuesta en el pensamiento de Marx, por un lado, y de Durkheim, por otro, con la afirmación, deducida del análisis sobre 'sociedad mecánica' y 'sociedad orgánica', de que "el individuo nace de la sociedad y no la sociedad de los individuos"- ha estado asentado en la cuestión de si explicar el mundo de los hechos y de los fenómenos de la vida humana, tendría que ser discutida si el principio mismo de comprensión tiene lugar o se ejerce, bien desde el individuo o bien desde la sociedad; reflexión como es obvio que partía de la pregunta de si ¿es o no el individuo el que de algún modo contiene a lo social o si por el contrario es 'lo social lo que contiene al individuo?. Y del que por otro lado surge la cuestión de preguntarse por el papel que desempeña el individuo dentro de una sociedad y cómo ésta limita o posibilita la acción del mismo; pero además, en esa colateralidad que antes hemos apuntado, la también pregunta sobre la individualidad del artista y su papel en la sociedad, esta vez en relación a los límites ejercidos sobre él. En relación a esta última pregunta, aunque es verdad que Durkheim no llega a desarrollar un específico análisis sobre la cuestiones propias de la relación sociedad-arte, sino sobre la estética de la obras de autores renacentistas como François Ravelais, en una de las breves alusiones a ella, opone [en el contexto de la educación] el conocimiento científico a las enseñanzas de tipo humanístico, de modo que, por ejemplo, el lenguaje es (ha de serlo) despojado de su función de representar -aún siendo una forma de expresión humana del mundo de vida- no sólo las cosas hermosas sino de representarlas ya no de la manera más hermosa, porque la caracterización de su función le depara otro rol, que es el de 
ponerse al servicio de los nuevos saberes integrados en el universo de las distintas funciones y utilidades sociales ${ }^{27}$.

En el análisis y estudio de la división del trabajo, Durkheim descubre dos importantes ideas (de carácter esencial): por un lado, la prioridad histórica de las sociedades, (donde la conciencia individual está totalmente fuera de sí); y por otro, la necesidad de explicar los fenómenos individuales por, o a través, del estado de la colectividad, y no ya el estado de la colectividad por, o a través, de los fenómenos individuales. El supuesto de la división del trabajo durkheimiano y sus dos ideas esenciales, nos permiten elucubrar sobre una hipótesis en relación al arte y al artista (la clase distributiva y el individuo enclasado) y las formas de construcción de su historia en tanto que el supuesto de la división del trabajo desmantela las relaciones de importancia, de prioridad operativa de uno respecto al otro y ambos en relación a la idea de sociedad.

En tal sentido, la "prioridad histórica de las sociedades" equivaldría al paisaje condicional de cosas, como prioridad determinante en el plano gnoseológico, por cuanto o bien se la conoce o bien la debe estudiar, puesto que determina la localización y temporalidad (esa conciencia del dónde y en qué momento se esta), que potencia la idea básica de la actividad. A decir, el paisaje condicional de cosas (de la que también es parte la conciencia de paisaje condicional de cosas: "maneras de obrar, de pensar y de sentir, externas al individuo y dotadas de un poder coercitivo en cuya virtud, según Durkheim, se imponen a él") es el resultado del "proceso de vida de determinados individuos" apuntado por Marx, de la acción cognoscitiva de los individuos, por lo que, en ese sentido, precede al sujeto de la actividad. Así, el individuo artista necesariamente tiene que conocer su paisaje condicional de cosas para definir no sólo su lugar, papel y modelo de actividad (de identificarse como sujeto entorno o próximo a un tipo de experiencias: en este caso la artística), sino, sobre todo, definirse como "yo" moral, como sujeto res cogitans autónomo (de ser experiencia de sí y sujeto de derecho). En relación a esto nos sirve

27 MacEvilley, thomas. De la ruptura al «cul de sac»: Arte en la segunda mitad del siglo XX. Ed. Akal/Arte Contemporáneo. 2007. Barcelona. España. 
la afirmación de Louis Dumont en Homo Hierarchicus, en oposición a Durkheim:

"Basta observar que los hombres concretos no se comportan; operan con una idea previa, aunque sea la de adaptarse a la costumbre. El hombre obra en función de lo que piensa, y si tiene hasta cierto punto la facultad de arreglar sus pensamientos a su guisa, de construir categorías nuevas, lo hace partiendo de categorías que están dadas socialmente, lo que su relación con el lenguaje le recordaría suficientemente. ${ }^{28}$

Resulta que la idea de hombre (también, como es obvio, la de artista) que en general consagró el cristianismo dibujada en la noción de persona -basada en la esencia de la humanidad, del individuo entendido como sagrado, casi absoluto y de derechos limitados sólo por los derechos de los otros individuos-, terminó convirtiéndose en la consagración durante siglos del pensamiento político y humanista occidental. Subyace hoy en la idea de hombre (y en su extensión en la idea de artista) la representación de la humanidad, y esto se debe a que previo a la idea de individualidad que cada uno de nosotros alimenta también subyace la idea de ser la mismísima esencia de la Humanidad, consagrada como base de las formas de pensamiento del orbe al menos Occidental (Hobbes, Locke, Rousseau).

Del mismo modo -y detrás de esta afirmación debería encontrarse a Dumont- el individuo artista no sólo es entendido como casi sagrado, sino que el artista mismo lo afirma de sí (las pinacotecas del siglo xx están repletas de ejemplos al uso) o lo ritualiza bajo enunciados del tipo de "el arte puede salvar al mundo", que no hace más que

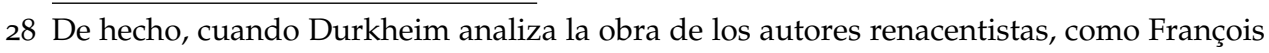
Rabelais, lo hace precisamente resaltando la tendencia estetizante de esta pedagogía, que permanece al margen de todo lo relacionado con la vida productiva. En este sentido, escribe: "Por una parte y por otra, el objetivo de la educación no es suscitar en el alumno energías productivas, no es armar su espíritu para la lucha, sino adornarle ya con una riqueza lujuriosa de conocimientos, ya con las gracias seductoras que comunican las bellas letras.... da la impresión - prosigue-de que se han perdido de vista las necesidades inmediatas de la vida y la urgencia que hay en poner al niño en condiciones de hacerle frente" (Durkheim, 1992b: 275) (30) Dumont, Luois. Homo hierarchicus. Ensayo sobre el sistema de castas. Ed. Aguilar. Madrid, 1970. 
afirmar la especificidad conferida a la actividad pero no la especificidad prudencial bien de su conocer o bien de su saber. Nótese por tanto, bajo la idea del individuo artista, y sin perjuicio de la aparición del "yo" como ser psicológico, una cierta oscuridad (un velo constatable de ignorancia) sobre aquel plano ontológico sobre la individualidad -la del alma, si era ésta una, divisible, libre o eterna- que en su momento, en forma de tratados y de discusiones, fue conferido de importancia (sobre todo epistemológica) en mentalidades filosóficas y eclesiásticas como por ejemplo: Descartes, desde la formulación, como elemento esencialmente determinante en el racionalismo occidental, del principio cogito ergo sum ("pienso, luego existo"); Nicolas Malebranche, con la doctrina personal del "ocasionismo" a través de la cual intentaba la síntesis entre el cartesianismo y el agustinismo, según el supuesto de que Dios constituiría la única causa verdadera, siendo todas las demás «causas ocasionales»; Spinoza, y la reducción a sólo una (la sustancia divina infinita) de las tres sustancias (el pensamiento, la extensión y Dios) consideradas por Descartes; Leibniz, y los siete principios fundamentales (Identidad/contradicción, Identidad de los indiscernibles, Principio de razón suficiente, Armonía preestablecida, Continuidad 'Natura non facit saltus', Optimismo, Plenitud); David Hume, y su teoría del conocimiento (Tratado de la naturaleza humana, 1739 ), a través de la cual afirma el carácter, en última instancia, derivativo del conocimiento siempre de la experiencia sensible, siendo esta la única fuente propia de conocimiento, sin la cual no podría lograse saber alguno; y Kant, a través de la anteposición al yo y a la conciencia existencial de la personalidad, de "la conciencia individual como condición de la razón práctica. Nótese por lo mismo, que la anteposesión del valor gnoseológico la especificidad conferida a la actividad a la experiencia como condicionante entonces de la peculiaridad del conocimiento, reproduce el error interpretativo consagrado por el cristianismo de la idea de hombre cotejada en la noción de persona como esencia misma a priori de la Humanidad. 


\subsection{ENMARCANDO EL VER / ESCENIFICANDO LA VISIÓN}

"La verdad es que la imagen no es lo único que ha cambiado. Lo que ha cambiado, más exactamente, son las condiciones de circulación entre lo imaginario individual (por ejemplo, los sueños), lo imaginario colectivo (por ejemplo, el mito), y la ficción (literaria $o$ artística). Tal vez sean las maneras de viajar, de mirar, de encontrarse las que han cambiado, lo cual confirma la hipótesis según la cual la relación global de los seres humanos con lo real se modifica por el efecto de representaciones asociadas con las tecnologías, con la globalización y con la aceleración de la historia."

Marc Augé

Enmarcando el ver / Escenificando la visión: condición contextual-circunstancia [dialécticamente] cultural. La idea de Marc Augé de que la imagen [en los tiempos que corren] no es lo único que ha cambiado no es únicamente interesante por la hipótesis que en sí misma abre, sino también porque es audaz en tanto quita, tal vez porque extiende a campos y niveles mucho más abiertos, la responsabilidad localizada (casi como un absoluto) sólo en la imagen; propone por lo mismo una liberación de las lecturas cerradas y oscurantistas de los modos-imágenes, condiciones-imágenes o construcciones-imágenes, a la vez que implica en todo el proceso de su lectura y conocimiento no solamente una condición contextual sino una circunstancia [dialécticamente] cultural, o sea, por un lado implica a todo un conjunto de relaciones históricamente ordenadas, y por el otro, a un sistema " $X$ " en el cual se representa el conflicto entre la memoria y el presente de la imagen. Esa relación condición contextualcircunstancia [dialécticamente] cultural constituye un campo de fuerzas -un conjunto de circunstancias históricas y de presentación de los modosimágenes actuales en intensa polaridad con los que le han antecedido- $\mathrm{y}$ sus presentes condiciones de circulación.

Escenificando la visión: mecanismos-procesamiento-representación. Las inquietudes entorno 
a los mecanismos de procesamiento y representación de la información visual y las transformaciones de la imagen [... calidad, multiplicación, especificidad, intermediación, naturaleza, democratización, distribución, manipulación, etc.] que han tenido y tienen lugar, concretamente en el contexto de la producción y práctica artística del Laboratorio de Luz, apuntan a la convicción de las posibilidades de la visualidad en tanto que marco potenciado de producción y en tanto que marco ampliado de comunicación. Inquietudes y preocupaciones, en todo caso, direccionadas (por atracción dialéctica) por los profundos cambios que las teorías de la percepción visual han venido definiendo [desde Kepler, con sus estudios sobre el análisis geométrico de la formación de la imagen en el ojo; los estudios sobre la visión en color, de Newton; el movimiento aparente de agrupaciones de puntos o campos, de Wertheimer; la Gestalt, con el establecimiento de los criterios de tipo generalista tales como similaridad, homogeneidad, cercanía, etc., hasta Hubel, Weisel y Barlow, con base en las potencialidades de las neuronas como células individuales]; por la relación de proximidad entre nuestra idea de lo visual y las nuevas tecnologías de la imagen, por la incidencia de procesos-nociones como lo de reproducción/representación de lo visible, o por los nuevos modos de comunicación incrementados por las posibilidades de la imagen interactiva; todo ello, potenciado por el renovado interés en torno al estudio de la imagen -entendida como una producción cultural y como una entidad siempre de polarización- desde diferentes áreas disciplinarias y de investigación.

Enmarcando el ver: proliferación de la imagen. La cuestión de la proliferación de las imágenes en las sociedades contemporáneas -preocupante en tanto que su naturaleza parece estar en un fenómeno de imitación y de asimilación y no del todo en una situación de devenir colaborativo, definen un nuevo campo de relación ("campo de fuerza") donde los modos de lectura [en todo caso de aproximación por oposición o por una polaridad conveniente] demandan la necesidad radical de una actualización y búsqueda de métodos y de análisis que presten especial atención a los actos de mirar, de ver y de conocer. La 
generación de los campos de investigación parece impulsada por la reorganización del conocimiento y las condiciones de su puesta en circulación, para explorar las repercusiones de las discusiones teóricas desde una metodología y actitud científica, deberíamos trazar en torno a las posibilidades investigativas de la práctica artística interesada en el lugar que ocupan hoy los recursos tecnológicos de la creación, producción y distribución de la imagen.

Escenificando la visión: generar un marco de contenidos. Unas palabras siempre pueden ser reemplazas por otras, y si estas no gustan, o no convienen, otras también pueden ser puestas en sus lugares. La cuestión es designar algo con exactitud, que la entidad que se designa exista tal como existe la palabra [extraordinaria o de designación]. La incorporación de conceptos como interactividad, realidad aumentada, telepresencia, imagen digital, estructuras narrativas de la imagen interactiva, percepción ampliada o cibercepción ${ }^{29}, \ldots$ en el desarrollo de los distintos proyectos artísticos ha planteado la necesidad de una serie de reformulaciones en torno al objeto de estudio inicialmente decidido en la estrategia investigativa; reformulaciones -que pone de manifiesto el impacto que sobre éste [éste objeto de estudio inicial] han tenido las nuevas tecnologías dominantes y la difusión de sus innovacionesen ocasiones exclusivamente condicionas (forzadas tras inexactitudes o vacíos) por la aplicación o incorporación de una versión [última] o recurso de carácter tecnológico sin que antes hayan sido atendidas sus propiedades específicas como medio, y su real conveniencia de cara la proyecto investigativo. La cuestión plantea el problema de la definición -no en términos de reconducción sino de descongestión- de las razones (podríamos decir objetivas o extraordinarias) de la evolución del espacio de la investigación a niveles-resultados de producción casi lúdica, en detrimento de una proyección humanística que por naturaleza el propio e inicial objeto de estudio sobre si mismo asentaba. Problema que al margen de la función y del uso (de las propias funciones y de los específicos usos) genera -puede haber generado puntualizaciones 
problemáticas- vacíos terminológicos y entrecruzamientos de nociones asociadas a conceptos o bien de aproximaciones prácticas sindicadas (en el sentido de su virtualidad) a funciones de valor, etimológicas y transcendentes, en aparente correspondencia (en el sentido de pensar la investigación) con el/o los conceptos en cuestión -estos en el sentido de la función de la investigación. Así, conceptos como realidad virtual, realidad aumentada, interactividad, etc., de problemas devienen en problematicidad de la cosa -pensemos, en tal dirección, la proyección de la cosa como condición última de su función de tipo social, como el zumbido continuo y funcionante de problema en su papel representado socialmente. Problematicidad, en tanto se proyectan deslizados [y no paralelos, pues sus etiquetados serían otros] del marco o del conjunto sistemático de distinciones (o de entidades funcionales y significantes) del que originalmente formaban parte. $\mathrm{Al}$ respecto Mieke Bal escribe en su texto "Conceptos viajeros en las humanidades":
"Los conceptos no son palabras comunes, por mucho que para hablar (de) ellos (se) utilicen palabras comunes (...) Los conceptos tampoco son etiquetas. Los conceptos (mal) utilizados de esta forma pierden su fuerza operativa; se someten a la moda y no tardan mucho en perder su significado". ${ }^{\circ}$

En esta dirección, formular la pregunta radical sobre los conceptos del ver y la visión activaría, es necesario que active, un primer marco (en el sentido provisional de "enmarcar") -de fabricar la pregunta en oposición a "la pregunta que nos viene dada, que nos llega planteada". Es importante, como punto de partida, construir un problema [construir la / o las preguntas] antes de encontrar una solución, de manera que ello de pie a la posibilidad de generar un marco de axiomas conceptuales -la pretensión delimitativa de ciertos umbrales y cualidades tanto de los dispositivos tecnológicos como de las nociones y conceptos, para que, por ejemplo, proyecciones como las de interactividad, sean un

30 BAL, MIEKE., "Conceptos viajeros en las humanidades", publicado en la revista Estudios Visuales. $\mathrm{N}^{\circ}$ 3, 2003 Pág. 30. 
"algo más que una potenciación lúdica o su carácter de juego físico", y sí el resultado del análisis de la situación en que ha podido darse esa $<<$ convergencia de los procesos conceptuales y perceptuales $>>$, de tal modo que la experiencia conlleve un papel formativo y tienda a desarrollar el pensamiento creativo de los usuarios en cuestión-, que, a su vez, permitan la creación de un conjunto de funciones y objetivos [valoración de hasta qué punto y en qué condiciones el desarrollo de estos nuevos espacios de representación aportan conocimientos cualitativos al campo de la experiencia visual] enfilados hacia el proyecto, y en última instancia, el conocimiento clarificado en torno a los límites y las metas finales del análisis [hablamos de la posibilidad de proporcionar, no en el sentido genérico sino en su especificidad, algunas respuestas a los interrogantes que plantea el desarrollo de las nuevas tecnologías en nuestra sociedad]; lo mismo sería encuadrar el conjunto de los conceptos, con la intención de elaborar un marco crítico como delimitación necesaria -aunque pueda a veces aparentar una cierta inestabilidad- para situar [centrar] el lugar desde el cual se produce o se va a producir el conocimiento. En tal sentido un modelo posible es el de la distinción tradicional de todo proceso de conocimiento, definida en cuatro fases: el sujeto que conoce [que en nuestro caso ha de ser el observador/espectador], el objeto conocido [los dispositivos tecnológicos de estimulación/interacción], la operación misma de conocer [¿cómo ha sido producido?] y el resultado obtenido que sería la información acerca del objeto [producir experiencia para el sujeto observador / espectador].

En términos operacionales podríamos ordenar entonces una relación efectiva, con garantías de objetividad, de la siguiente manera:

1- Sujeto que conoce.

2- Objeto conocido.

3- Operación misma de conocer.

4- Resultado equivalente a la información acerca del objeto. 


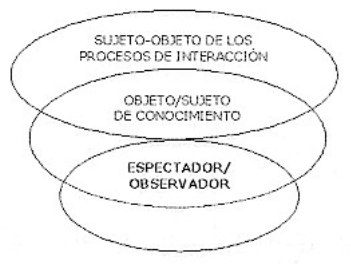

Figura 5: Esquema sujeto de conocimiento/procesos de interacción

A partir de este esquema, el espectador/observador sería simultáneamente objeto-sujeto de conocimiento y sujeto-objeto de los procesos de interacción, pero las preguntas acerca de la naturaleza y el carácter del ver y la visión aún no han sido formuladas y sería difícil llevar a cabo esta tarea si no tenemos en cuenta la siguiente reflexión:

"1. Primera constatación obligada: que los actos de ver-mirar, ver, darse a ver, ser visto, visibilizar u ocultar, exhibirse o mironear, vigilar u observar, mostrarse como objeto para la mirada de otro, o ser sujeto de ella, etc.- no son actos incomplejos, que puedan analizarse satisfactoriamente desde una perspectiva exclusivamente "biológica" o fisiológica, ni aún desde alguna analítica puramente fenomenológica o incluso trascendental (como la kantiana de las condiciones de posibilidad de la percepción). Más allá, los actos de ver han de ser considerados como hechos culturales, condicionados - a cualquiera de los lados de la mirada, en toda la complejidad de su proceso- por una cierta knowingness, por una determinada y específica competencia cultural -de los agentes implicados en el proceso. Los actos de ver son actos culturales, y están culturalmente condicionados." ${ }^{11}$

31 BREA, JOSÉ LUIS., "Actos de ver", publicado en nonsite, $\mathrm{n}^{\circ}$ 3/Año 2004. Edición online: http://tinyurl.com/dxmehef [Fecha de consulta: 14-marzo-2013] 
Enmarcando el ver: Generar un marco epistemológico.

"Puesto que en el período contemporáneo son la tecnología y los medios de comunicación los verdaderos portadores de la función epistemológica: dentro del aparato es donde la percepción está más indisolublemente ligada a la epistemología de lo que nunca podría estarlo en las formas tradicionales o en los ejercicios tradicionales de los sentidos puros, sin mezclar (ya sea el lenguaje o la visión y el color, o los óleos)." 32

Hoy una cuestión como la de la construcción de un artefacto, supone, en el mismo acto constructivo, también la construcción de un problema de carácter epistemológico, la puesta en marcha como problema de una otra relación sujeto-objeto, una otra relación entre el "sujeto" (ser cognoscente) y el "objeto" (todo proceso o fenómeno sobre el cual dicho sujeto desarrolla su actividad cognitiva). Sin embargo, lo verdaderamente importante de esta nueva otra relación no consiste en el hecho de que hoy, como nueva construcción -en todas las épocas y tiempos las nuevas construcciones de artefactos o cosas han generado un problema similar- ésta genere como tal un problema de carácter epistemológico, sino en el conjunto de partes que el depositamiento (contenidas no a voluntad sino como datos-memoria heredados en la extensión del objeto) constituyen las raíces-problema de la relación general, en el conjunto de las memorias o epistemes actuantes como contenidos extensibles al sujeto y como contenidos extendidos [tal vez expandidos] en el objeto. En este sentido la idea de problema de carácter epistemológico a la que nos referimos deduce, en el referido al conjunto de partes en depositamiento, a unas ciertas limitaciones del ver en relación a la mirada y el orden de lo visual: toda nueva construcción es un conjunto de las memorias o epistemes actuantes como contenidos extensibles al sujeto y como contenidos extendidos [tal vez expandidos] en el objeto, pero en oposición casi radical al ver y al mirar, aunque no así con la ordenación de lo visual.

32 JAmeson, F., El posmodernismo y lo visual. Ed. Episteme, Valencia. 1985. Pág. 6. 


\subsection{TRAZAR UN PLAN CONFORME A UN FIN}

En occidente sólo el empuje de una gran presión social (distorsionadora) es lo que ha hecho que lleguemos a considerar las técnicas de leer, escribir y contar, como útiles para sobrevivir. Al margen de ellas, el propio sujeto occidental, se encuentra sumido en la más profundas de las ignorancias, respecto a su propio paisaje cultural. La escritura y lectura de la palabra sólo parecen servir para enumerar o contar la cosa a la que representa, sin embargo, por sí misma parece no poder hacer ver la cosa tal cual. En cualquier caso la palabra escrita, leída y contada necesita de algo más para poder abrirse al ver de la cosa, necesita un complemento técnico (externo a ella) que la acoja: así, en relación a una técnica y según una estrategia, es que se vuelve útil conforme un fin. El proyecto de armar una herramienta didáctica que visibilice y atienda esas partes mínimas (elementos discursivos) que entran en juego en el proceso constitutivo de la idea de idea de proyecto de obra constituye una noble empresa que conforme a un plan (entre la escritura, la lectura y su narrativa) y conforme a un fin (acercarnos a la explicación funcional y a la especificidad de dichas partes), para nada perjudicaría a nada, aún cuando no estuviéramos en disposición de completar su realización. En todo caso dicho esfuerzo de realización es del mismo modo un esfuerzo de escritura crítica, como de igual manera lo es de lectura, conforme a una simple dirección teórica de la acción: la elaboración crítica del material o la adopción de la disposición técnica según (o sobre) procesos objetivados y observables.

"Una idea no es otra cosa que el concepto de perfección no encontrado aún en la experiencia. Por ejemplo la idea de una república perfecta, regida por leyes de la justicia, ¿es por esto imposible? Basta que nuestra idea sea exacta para que salve los obstáculos que en su realización encuentre. ¿Sería la verdad una mera ilusión por el hecho de que todo el mundo mintiese? La idea de una educación que desenvuelva en los hombres todas sus disposiciones naturales, es, sin duda, verdadera."33

33 Kant, Immanuel. “Sobre pedagogía”. Ed. Elaleph.com. 2000. 
La cuestión radica en trazar un plan conforme a un fin, de tal forma que se entregue o disponga una orientación que poco a poco pueda realizarse. Por ejemplo, los profesores Rusos (Filikppenko ${ }^{34}$, entre otros) que impartían clases de pintura en el Instituto Superior de Arte de La Habana, hablaban constantemente de la cuestión del orden del color 35 , de su superposición, con tal de lograr el volumen óptimo de aquella naturaleza muerta que estábamos representando a través de la pintura: De todo aquel objeto que en pintura queremos representar, sus brillos son los que están físicamente más próximos a la fuente de luz que los ilumina, $y$, desde ese punto de vista perceptivo, se haya si no en el centro de nuestra atención, al menos en esa órbita de proximidad a nosotros. La lógica de su instrucción era muy simple. Consistía en que previamente hiciéramos un estudio de la topografía del color en el modelo y de ese modo clasificar el número de capas posibles a representar; dichas capas deberían ser enumeradas desde los colores más oscuros -observados en la profundidad del modelo- hasta los brillos más claros e intensos localizados en la superficie. Esto suponía por tanto que las capas más profundas y oscuras deberían ser las primeras en ser representadas en el lienzo, luego los grises o intermedias, y por último, los brillos y matices intensos. De este modo la fisicidad misma de la ordenación de las capas de pigmento añadía y otorgaba un relieve real [algo más], o una cierta espacialidad, a la ya pura e intencionada representación de los relieves observados en el modelo.

Se trataba, entonces, de introducirnos en un pensamiento sobre la pintura, de pensar una cierta ordenación previa a la gestualidad misma o la acción de pintar, que en definitiva parece contar para algo, pero no para todo. Esto, en todo caso, no sólo introducía una cuestión que en ese momento nos resultaba difícil entender, como era el de pensar o atender aquellas argucias referidas a la naturaleza de la pintura, sino

34 Artista ruso que impartió clases en el Instituto Superior de Arte de La Habana entre los años 79 y 82, en la Facultad de Bellas Artes.

35 Siguiendo con las enseñanzas de El tratado de la pintura de Leonardo da Vinci: "Entre los colores de los cuerpos el que tenga mas blancura se verá desde mas lejos, y el mas oscuro por consiguiente se perderá a menor distancia." Edición online: http://es.wikisource.org/wiki/El_Tratado_de_la_Pintura:_167 [Fecha de consulta: 7 de septiembre de 2011] 
sobre todo nos introducía -conforme a un fin- en una cuestión que en los ámbitos de la teoría del arte estaba siendo largamente debatida, como era la cuestión de la representación. Se trataba, sin duda, de incentivar en nosotros no sólo el interés por el oficio de la pintura, su artesanalidad y por la acción misma de pintar, sino, en buena medida, el interés por el pensamiento entorno a la pintura; a decir, sobre aquello de la responsabilidad de pensar la naturaleza y la idea de la pintura en relación -trans-objetivadora ${ }^{36}$, diría García Bacca- también con los otros.

\subsubsection{La idea desde el inicio: construirla es entenderla.}

Respecto a aquello que la metodología de detección de los elementos discursivos pretendería resolver, estaría siempre circunscrito a todo lo relacionado con la idea de idea de proyecto de obra que desde los ámbitos de la teoría y de la educación de las prácticas visuales sólo ha podido ser mostrado como descripción, y por tanto, a través de las construcciones representacionales de imágenes -a modo de técnica de disfraz o de visión selectiva de procesos cognitivos y de tamización de significaciones- ocupadas de explicar el comportamiento esencial de cosas que tal vez no admiten dicha estructura de representacionalidad decodificadora. Lo que los elementos discursivos colman es todo aquello, limitado en el análisis, de lo que la academia (el ejercicio como tal) no ha podido extraer ni su voz y ni su naturaleza, por haberse centrado exclusivamente en los significantes entonces vaciados, en el plano solo de la expresión (de la forma): todo aquello que necesariamente hay que pensar y todo aquello que necesariamente hay que saber como condición indispensable para la constitución de la idea, aunque añadiendo además, en tanto que escritura de lo biográfico que debe vivirse por ser una imprescindible condición (la de la experiencia) de cara al potenciado de

36 García bacCA, J.D. Cuaderno sistemático de filosofía actual. Colección Trópicos. Alfadil Ediciones. Dirección de Cultura de la U.C.V., Venezuela, 1991. p. 24-25

"La actividad creadora, inventora o productora del hombre moderno - en cuanto a serse modernoes des-objetivadora del universo natural -dentro del cual el hombre es hombre natural-, y transobjetivadora o dadora de objetividad nueva: "Humanización del universo -y-universalización del hombre". 
las unidades básicas de significación.

Elementos discursivos -método, herramienta para la organización y la constitución de la idea de proyecto de obra- toma como dominio el cuerpo oracional de la estructura idea (por tanto los elementos discursivos para la detección de las partículas menores de dicha estructura idea.)

"La validez de las propuestas artísticas no depende de ningún presupuesto empírico, y mucho menos estético, sobre la naturaleza de las cosas. Ya que el artista, como un analista, no se encuentra directamente preocupado con las propiedades físicas de las cosas. Sólo se halla preocupado por el modo: 1) en que el arte tiene la capacidad de crecer conceptualmente, 2) como sus propuestas tienen la capacidad de continuar con dicho crecimiento. En otras palabras, las propuestas del arte no son fácticas, sino "lingüísticas" en su carácter, esto es, no describen el comportamiento de objetos físicos o incluso mentales; expresan definiciones del arte, o las consecuencias formales de las definiciones del arte. Del mismo modo, podemos decir que el arte opera sobre una lógica. Ya que veremos que el sello característico de una pregunta puramente lógica es el hecho de que se preocupa por las consecuencias formales de nuestras definiciones (del arte) y no con preguntas de hechos empíricos.

Repitiendo lo anterior, lo que el arte tiene en común con la lógica y las matemáticas es el hecho de que se trata de una tautología; esto es, la "idea del arte" ( $u$ "obra") y el arte son lo mismo y pueden apreciarse como arte sin tener que salirse del contexto del arte para su verificación." 37

Los elementos discursivos no fundan nada, puesto que sería muy pretencioso hacerlo, sino que exploran una posibilidad. En todo caso no es la obra, no es el proyecto, no es la idea, lo que nos interesa, es el sujeto artista. La naturaleza desde el inicio: la experiencia importa más. 
También en esa dinámica, la estructura de procesado metodológico conllevaría unos pasos mínimos (concretamente cuatro), cuyo nivel de complejidad variaría en relación a la complejidad de la pretensión y de la búsqueda, aunque especialmente en relación a la necesidad cognitiva del sujeto cognoscente artista. Así, en su esquematización básica, los pasos serían los siguientes: uno, entender la lógica de detección -o el para qué nos sirve gnoseológicamente-; dos, decidir el plano de triangulación operacional (los puntos de anclaje y de objetivización, que dotarían de veracidad el proceso); tres, detectar y analizar los elementos discursivos en cuestión detectados; y cuatro, constitución de la idea de idea de proyecto de obra.

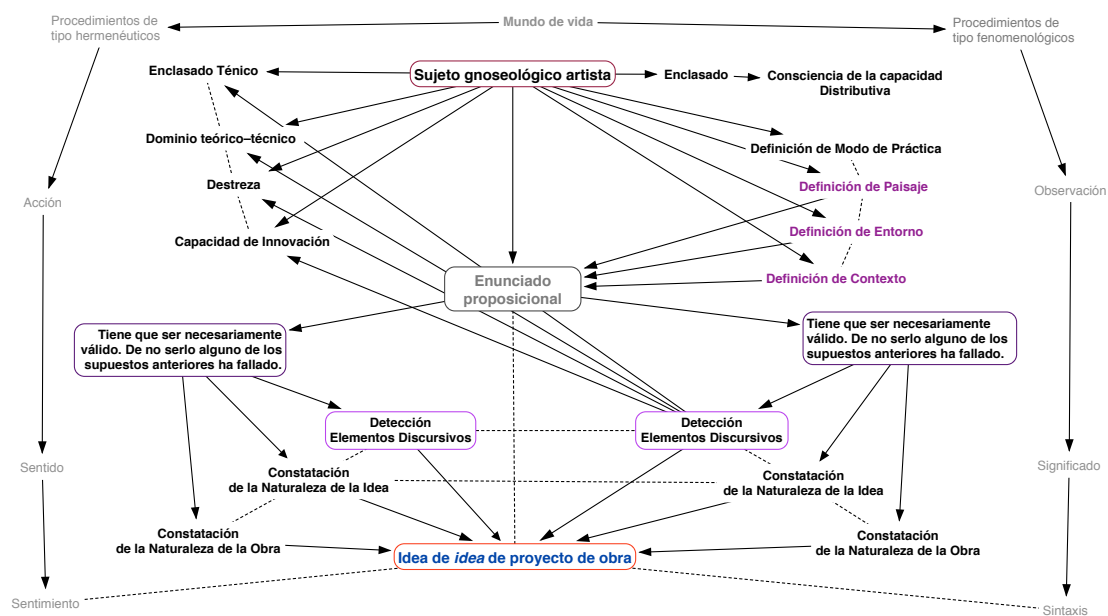

Figura 6: Esquema de la secuencia (1) relativa el sujeto gnoseológico artista y el proceso de detección. 


\title{
3.4 LOS FUNDAMENTOS TEMPRANOS DE LA EXPERIENCIA
}

Un error habitual, relativo a la enseñanza del arte, es atiborrar a los estudiantes con imágenes de todos los tipos y momentos históricos desde los que dichas imágenes han sido de algún modo extraídas. Dicho error descansa comúnmente en el supuesto de que a través de esas imágenes es posible explicar, o bien cuestiones disciplinares, o el arte tal cual, o bien el modelo de práctica artística, o de ésta, entonces, la temporalidad. Es un error habitual, en apariencia intrascendente, pero extremadamente condicionante en tanto que detiene (pone límites) a la posibilidad misma de ver: la mirada no se educa con las imágenes sino a través de la experiencia de ver, y ello es en tanto que las imágenes no son en sí el conjunto de cosas a las que de algún modo representan.

\begin{abstract}
"La imagen procede, pues, de un modelo que la genera, sin que por ello se asemeje necesariamente a él. La imagen no es una cosa, sino una relación. Es siempre imagen de algo o de alguien sin que por ello sea su copia." 38
\end{abstract}

Son hasta un cierto punto disyuntivas y por ello, más que nada, son más bien poco de eso de donde provienen. Lo importante de las imágenes no es su relación con el pasado sino su conexión con el presente, ese estado puente que en el fondo las atemporiza dotándolas de intermedialidad. La imágenes son intermediales, conectoras de presencialidad entre tiempos socializados. Su presente es lo que de algún modo conmueve. El recurso constante de la palabra hablada [la oralidad] y no tanto de la imagen o datos relativos a ellas (el nivel constante de complejidad de los conceptos tratados e introducidos debe crecer progresivamente) ha de permitir que el conjunto de los estudiantes tiendan a ser, por un lado, más sociables con los otros estudiantes en tanto prestan más atención a lo que hacen y dicen los demás, y en consecuencia a imitarse positivamente, y por el otro, a ampliar (amplificar de igual manera, puesto que de algún modo se desplazan palabra y escritura a un lugar

38 MeLot, michel. Breve historia de la imagen. Ed. Siruela, Madrid, 2010. Pág. 12-13. 
primordial como herramienta de negociación e intercambio) el lenguaje como herramienta ya no tanto en el rol lógico de la comunicación, sino, cosa de altísima importancia, como herramienta base del conjunto de sus acciones reflexivas.

En ese sentido el recurso de la imitación deviene en competencia -esto reactiva un acto reflejo adquirido en la niñez, resultado de lo que investigadores como Robert Putnam ${ }^{39}$ llaman resultado de la estimulación parental, detectada en la mayor o menor activación de los circuitos neuronales del niño en el cerebro y en tal sentido es medible (deducible quizás) su proclividad o no, a socializarse o al intercambio con respecto al grupo-, y como tal en grados cualitativos de atención sobretodo en relación a los objetos, calidades o temas puestos en cuestión: la atención sobre la fisicidad de los objetos crece notablemente, sobre todo aquello que concierne a los tamaños (tratados en términos de proporciones), aspectos (en el sentido de la complejidad o no de su representación), y fisicidad o abstracción (según la potencialidad teórica de lo observado).

39 PUtNAM, Robert. "E Pluribus Unum: Diversity and Community in the Twenty-First Century", Scandinavian Political Studies, 30/2, 2007, pp. 137-174. 


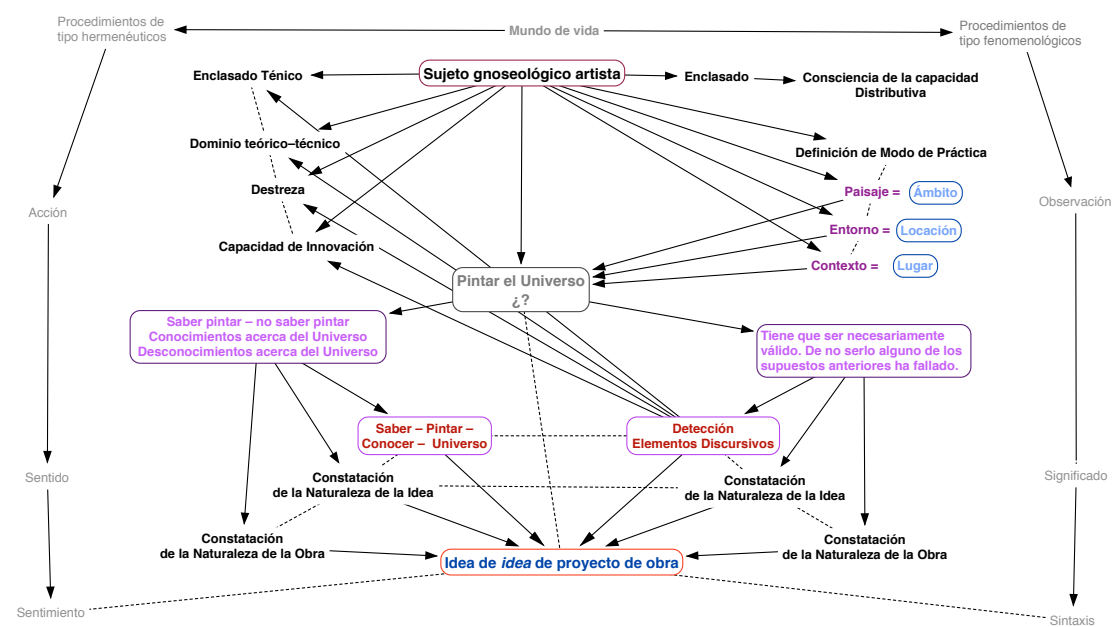

Figura 7: Esquema de la secuencia (2) relativa el sujeto gnoseológico artista y el proceso de detección.

\subsubsection{Por una idea base de "experiencia"}

La experiencia es una parte activa del conocimiento y de la observación... "Experiencia (del latín experiri, "comprobar") es una forma de conocimiento o habilidad derivada de la observación, de la participación $y$ de la vivencia de un evento o proveniente de las cosas que suceden en la vida, es un conocimiento que se elabora colectivamente". Esta definición, diríamos que técnica, en el sentido habitual usado por Gustavo Bueno, encontrada en el segundo de los grados clasificatorios de Wikipedia (la primera es, bajo la fotografía de una anciana, "La experiencia es en parte derivada de la observación y de la compañia de los que ya son sabios"), contiene todo aquello que nuestra didáctica necesita para adoptar su cuerpo igualmente definitorio. El primero de todos esos elementos que contiene, y que necesitamos, es su aparente grado de popularidad (ocupa el segundo de los lugares) deducido del orden de clasificación entre otras muchas definiciones de experiencia. Esta definición, popular 
en apariencia, apunta de partida, como toda buena definición, por un lado a experiri, su concepto raíz anclado en el latín, que más que "comprobar" en el sentido de que dicha acción tiene o puede tener lugar sin más, antepone la posibilidad de que ello pueda ser o darse como afirmación autónoma y de que fluye, por tanto, hacia lo posible (como autosuficiencia) de la comprobación: hacia el posible poder comprobar como potencia misma de lo crítico.

"Experiencia será, en consecuencia, la multiplicidad continua y unitaria de lo que es el conocimiento." $4^{\circ}$

\subsubsection{Modos de relación E experiencia de relacionar}

Conexión de la producción artística a la producción y distribución de modos de relación, de formas autónomas de producción de mundos relacionables o de los modos de organización de la subjetividad, la percepción y el comportamiento.

Estos pueden ser descritos sobre la base de cuatro características fundamentales, constatables o reconocibles, por altamente característicos en el pensamiento epistemológico contemporáneo que son:

1. tiene un carácter situado,

2. trabajan en y desde la policontextualidad,

3. son generativos,

4. son relacionales.

Ahora bien, esta ordenación de los modos -provenientes del análisis que Jordi Claramonte hace de las distintas autonomías-, traída y encajada en el contexto de análisis y de puesta en relación de los elementos discursivos debe ser entendida y abordada desde sus fuerzas proyectantes (resolutivas, si se quiere) o posibilidades de

40 BENJAMIN, WALTER. Sobre el programa de la filosofía venidera. Obras II, 1, pág. 172. Edición online: http://www.circulobellasartes.com/benjamin/termino.php?id=98 [Fecha de consulta: 12 de marzo de 2011] 
instrumentalización que, dicho de otro modo, suenan a algo así como entenderlas desde su carácter de nodos orientativos de objetivación o de conductores de formaciones fuertes en la puesta en relación, por otro lado y ya en marcha, de los distintos elementos designados como discursivos. De todo ello, con ejemplos de sus comportamientos específicos daremos cuenta más adelante.

En eso que denominamos experiencia de relacionar, estas cuatro características cumplirían igualmente un cierto paquete de funciones fundamentales que pasarían por una readecuación -más bien extensióno desplazamiento de los límites que las definen. El primero de esos desplazamientos comprendería una cierta instrumentalización del conjunto de las categorías, de tal modo que su uso en el ámbito de la reflexión siempre mantendrían un carácter conveniente y visiblemente adecuativo, como por ejemplo: en relación a algunos conceptos -de un uso entendido como función alusiva y por tanto con un trasfondo descriptivo-, pasaríamos a una potenciación y uso del concepto en sí, de tal modo que el campo semántico del concepto crecería o decrecería convenientemente según las circunstancias y la estructura sintáctica, permitiendo que sus etimologías sean utilizadas como herramientas -en todo caso herramientas de ordenación didáctica para la conformación de potenciales unidades de discursividad en la ideación de la relación o cuestión obra.

La cuestión consistiría en la potenciación de estos conceptos -para Claramonte, características de los modos de relación ${ }^{41}$ o estética modal ${ }^{42}$ - como formas de hacer y de transformar, más que su utilización tan sólo como entidades, en un sentido básicamente contemplativo, de

41 "Llamo modo de relación a un conjunto de disposiciones relacionales que establece y regula un determinado estado de cosas. Esto es, al decir "modo de relación" aludimos a una conformación relativamente estable de posibilidades y prioridades perceptivas, relacionales y expresivas." http://jordiclaramonte.blogspot.com.es/20o8/12/estetica-modal-conceptos-basicos.html

42 "La estética modal pretende -nada menos- dar un marco conceptual general a la sensibilidad y las prácticas artísticas tomando como referencia no las nociones clásicas de artista-obra-espectador (que Bourriaud mantiene e hincha aún más) sino dandole todo el protagonismo a los "modos de relacion" que serían, a mi entender, los verdaderos agentes en todo proceso de organización de la sensibilidad." URL: http://jordiclaramonte.blogspot.com.es/2008/o5/esteticamodal.html 
saber. Tal potenciación recordaría como posicionamiento, con toda la distancia necesariamente supuestas, la famosa tesis 11 de Marx sobre Feuerbach, en relación al cambio de rol de la filosofía ante una realidad que lo solicitaba: "Hasta ahora los filósofos no han hecho más que saber-vamos a saber sobre el mundo-, luego, lo que hace falta es hacer, transformarlo"; en ese sentido, la potenciación de la que hablamos interrogaría, en la misma medida y manera de ser usados los conceptos, sobre el propio principio hacer y potencia de transformación del concepto tal cual.

Por tanto, el juego de cambio de rol del uso de estos conceptos en el entorno de los elementos discursivos, debería servir como principio puntualizado de hacer, al margen entonces de la voluntad antropológica de -como objetivo último- querer decir ante simples ordenaciones ordinarias, y sí, definido en un contexto de intensidad crítica, como un individuo pensante dotado de autonomía.

El carácter de situado alude al hecho de que dichos modos suceden en un contexto de sensibilidad y acción social e histórica determinada y que ese modo de estar situado es indiscernible del modo de relación y de su autonomía modal. No cabe duda de que la formación de una sensibilidad tiene lugar a través de numerosas acumulaciones de disyunciones históricas también sensibles, de gradaciones de valor, de socialidad, producidas por dos condicionantes de sensibilidad (a modo de relación copulativa madre-padre) en cuya balanza una de ellas es considerada siempre como algo cierto y afín, y sin embargo la otra, en todo caso también determinante en la disyunción, puede que no sea jamás considerada o tenida en cuenta. Tal contexto de sensibilidad, del orden que sea, siempre dará cuenta de uno de los dos condicionantes de sensibilidad como jerárquico -apuntará como matización siempre a uno de ellos-, bien sea el condicionante padre, bien sea el condicionante madre. En todo caso el contexto de sensibilidad es por igual una condición imprescindible para que toda cosa social pueda como tal tener lugar, y por lo mismo, para que el carácter de situado le aluda sin más como determinante en la constitución del modo obra.

En ese sentido deberíamos pensar que eso del carácter situado de una obra o suceso artístico sólo puede entenderse si la obra como tal ya ha tenido lugar, del mismo modo que el contexto de sensibilidad ha 
propiciado su ser de un modo o de otro, ya sea como necesidad de acción o como franja de sensibilidad histórica. El carácter situado nunca, y para nada, es anterior a la cosa obrada: es, en esa dirección tan socializado como la cosa obra en sí; es una relación-socialidad puesta en circulación en la que se dan por asumidas todas las consecuencias de su acontecer y dimensión formativa, en tanto que se deja en circulación porque ha sido (debería haber sido) entienda como algo, entonces, común. Ahora bien, entender este concepto en relación a la pedagogía orientada a la enseñanza del arte es importante puesto que deduce la progresión formativa (en relación al lenguaje) de la cuestión obra, cuya base parte de la tensión entre ideación, conceptualización y registro, o bien, de la tensión entre idea y producción, como el obstáculo a resolver en el acercamiento inicial al proceso de organización del valor arte y de los distintos modos de prácticas relacionados con él.

Esta noción destapa, a la vez que introduce, una relación de observación novedosa en las conexiones analíticas objeto-contexto y objeto-paisaje. La novedad consiste en el hecho de que deduce como conformada (por tanto como operativa y también como lugar desde el que es posible partir para una estrategia de análisis) una cierta sensibilidad de cosa, una sensibilidad a nombrar (convenientemente) según sea el caso, que por otro lado anticipa, más que insinúa, el límite de su campo de acción sensible como campo dado, de por sí y ya, como espacio de teorización. Deduce, de igual modo, una autonomía, una adaptación a las reglas que determinan una cierta funcionalidad del entorno relativo a la cosa obra o a la práctica en cuestión, y eso significa entre otras cosas una cierta objetividad en la consolidación de los grados de aspiración del (o de un) conjunto de individuos hacia la novedad "cosa obra" o "práctica" y además una cierta orientación social del conjunto de individuos hacia eso que de algún modo se pretende instaurar como nuevo.

El carácter situado no revela una verdad-como totalidad-de la cosa en torno a la cuestión obra o a la cuestión modo de práctica, es más bien una glorificación del entorno mismo como determinante en el conformado de aquello que de algún modo ha llegado a situar, de aquello que de algún modo ha llegado a entornar; es más bien, eficacia de decir aquel otro lado relacionado y conexo con ese otro propio del objeto, de la 
"cosa obra o de la cosa práctica": eficacia entonces de advertirlo como legible, y por lo mismo, como posibilidad de lectura o como dirección de sentido. Por tanto es un concepto orientativo, que debería marcar las direcciones iniciales en la investigación constructiva de la idea-ahora, o, por lo menos, situar el marco de conformación de aquello a obrar.

En ese sentido todo concepto elegido para el desarrollo constitutivo de una idea de obra debería considerársele como situado y, por lo mismo, en un entorno de sensibilidad que de antemano lo condiciona, aportándole distintos grados de objetividad bajo su radio de influencia. Es la objetividad emanada o irradiada del entorno de sensibilidad aquel aporte que la fuerza de sensibilidad misma hace -en tanto que conexión de objetividades configurables-, a la cosa obrada; es por tanto objetividad cedida, como grados valor de cognitividad, a la cosa ya conformada y en circulación. Circulación, por otro lado, que debería pensarse como activada -de antemano- en el entorno mismo de sensibilidad, y no como hasta ahora habíamos pensado: que su flujo se producía y tenía influencia a partir de la obra misma y de su puesta en escena pública, cosa que en todo caso refería a una cierta forma de omisión del comienzo, por tanto a una cierta incertidumbre de objetividad que emparenta, todavía, las nociones "obra de arte" y "milagro".

Ahora bien, ¿pensar en términos de modos de relación tiene algo que ver con la constitución de la obra, con el diseño del proyecto y la articulación de la idea de obra, o sólo guarda una relación de proximidad teórica? ¿Para qué sirve tener en cuenta eso de los modos de relación? Históricamente todo aquello que concierne al proyectado de la obra ha sido pensado en términos del producto final, de la cuestión obra en el sentido de su objetualización y puesta en escena, y en menor medida en el sentido de toda la cadena de producción de la discursividad, o, dicho de otro modo, en menor medida en el sentido del devenir productivo de la relación, bien conocimiento-experiencia-lenguaje, o bien, conocimientoexperiencia-regristro. 


\subsubsection{Sobre las relaciones}

¿Que tiene que ver esa historia teórica con nosotros? Los marxistas, la ilustración, los presocráticos, etc. el pensamiento de hoy está dependiente del pensamiento presocrático, los problemas en términos culturales son los mismos, las cuestiones de preocupación esenciales, la idea de la matemática, la geometría, Dios y la historia. En todo caso la respuesta menos elucubrativa y tangencial sería: giramos entorno a los mismos temas. Si admitiéramos que no guardamos ninguna relación (ninguna potencia de valor con otro algo), que no tenemos esa condición sistemática con esa forma de pasado, entonces estaríamos admitiendo igualmente que no pensamos.

El fundamento primero debería ser que, las relaciones, casi nadie sabe lo que es. Es sin duda un concepto muy difícil de abordar, puesto que es casi contradictorio. Es difícil de abordar porque generalmente se confunde con otras categorías: a veces con interacciones, a veces con acciones, y a veces con pasiones. Lo cierto es que la clasificación, que hoy entendemos como motivo de la confusión, proviene de la enumeración (tabla, o rapsodia según dice Kant) Aristotélica de las diez categoría (sustancia, cantidad, cualidad, relación, etc.) en cuya ordenación la relación ocupaba el cuarto lugar. Según ello en lugar de decir, como hoy decimos, "Yerma mantiene una relación con Juan"43, deberíamos hacerlo al estilo de, "Yerma mantiene una acción con Juan", o bien, "Yerma mantiene una interacción con Juan".

La cuestión del uso de relación pasa por su aparente carácter neutral, por la aceptación de que en ello no se juega nada, de que "no pasa nada". Sin embargo, la cuestión de la relación (de las relaciones representadas, y por lo tanto exentas) es más complejo, enrevesado y laberíntico de lo que creemos, cuya observación -en principio desde la teoría de las ciencias- se ciñe a su funcionamiento en el espacio gnoseológico (en el de sus ejes: sintáctico, pragmático, semántico), pero sobretodo a su pertenencia al eje sintáctico. En ese sentido el fundamento de la relación -la posibilidad de que se le pueda admitir, preguntarían los escolásticossugiere, o mas bien sería, la idea de una cierta independencia entre las

43 Referencia a la obra Yerma de Federíco García Lorca. 
partes para que se pueda establecer, en términos de razón, y sólo de ella, una relación. Dicho de otro modo es necesaria una autonomía e independencia entre las partes, claro esta, autonomía e independencia de su funcionamiento, por lo que es lo mismo, que sean diferentes. La oposición a esto la podemos encontrar en el ejemplo de las semejanzas usado por Gustavo Bueno en sus conferencias sobre la filosofía de las relaciones: cuando decimos "Juan es semejante a Pablo, en que son blancos", la condición inherente de la semejanza emana o está en Pablo. En tal sentido Pablo es como es y es Juan el que se le asemeja. La cuestión es, y por lo tanto adquiere dimensiones paradójicas, que la semejanza comporta una relación para ambos según la relaciones simétricas, de tal modo que si Pablo es semejante a Juan debería, asimismo, ser semejante a Pablo, lo que por otro lado quiere decir, por un lado, que entonces habría dos relaciones de semejanza, una para cada caso o cada parte, por otro, que la relación se produce sólo entre partes distintas por lo que en el caso de Juan y Pablo, lo que produce la condición inherente a la semejanzas no son los iguales o simétricos Juan=Pablo, sino el elemento connotativo "que son blancos". En ese sentido, y extrapolado a nuestra idea de experiencia de relacionar, nosotros deberíamos, para poder articular nuestros juegos de relaciones, hacernos con los elementos connotativos de las partes -aquellos distintos uno de los otros- para su emparejamiento, en términos de contrarios convenientes de significación. Así, en la práctica, como por ejemplo el caso de la obra con la que participamos en la Bienal de Arquitectura y Paisaje de Canarias, la estructura básica de establecimiento de su relación conveniente fue: Paisaje $\triangleright$ Entorno $\triangleright$ Contexto $=$ Ámbito $\triangleright$ Locación $\triangleright$ Lugar $=$ Canarias $\triangleright$ Tenerife $\triangleright$ Castillo Negro $=$ Historia las Islas Canarias $\triangleright$ Historia de Tenerife $\triangleright$ Historia de Castillo Negro $=i$ ? 


\subsection{PROBLEMA DEL CONOCIMIENTO EN LAS PRÁCticAs} ARTÍSTICAS

"En el desinterés kantiano se disfraza, apenas reconocible, el goce artístico. Pero este goce, tal como lo entienden la conciencia común y una estética complaciente, tomando como modelo el goce real, probablemente no existe. La participación del sujeto empírico en la experiencia artística telle quelle es sólo limitada y modificada, y podría disminuir a medida que creciera el rango de las obras. Quien goza de ellas de forma demasiado concreta es un hombre trivial; las palabras como deleite de los oídos le extraviaron. Pero si se extirpase hasta la última huella del goce, la cuestión de para qué existen en definitiva las obras de arte nos llevaría a confusiones. Tanto menos se goza de las obras de arte cuanto más se entiende de ellas. Anteriormente, la forma tradicional de enfrentarse con las obras de arte, forma que tiene su importancia para la explicación de las mismas, era la de la admiración: las obras de arte son así en sí mismas, no para el que las contempla. Lo que de ellas venía hacia él y le arrebataba era su verdad, lo mismo que en los tipos kafkianos, en quienes la verdad sobrepuja a cualquier otro aspecto. No eran meros instrumentos de un goce de orden superior. La relación con el arte no era la de la posesión del mismo, sino que, al contrario, era el observador el que desaparecía en la cosa."44

La experiencia del arte como la de casi todo en la vida no es una experiencia desinteresada. No lo es en tanto que no aflora ni guarda relación alguna con la espontaneidad ni con lo azaroso y porque no es, en todo caso, el brotar de la cosa en, como ocurre con la vida, sino más bien el resultado de la estructuración de algo entre o de la puesta en relación de dos o más ámbitos; diríamos que del cultivo parcelado -enclasados, en tanto son ámbitos y también conjuntos de partes las que confluyen en la nueva relación- de significados. Ahora bien, resulta que con la escritura y el pensamiento relacionados con los modos de prácticas artísticas no

44 ADORNO, Theodor W., «El “Goce Artístico"» en Teoría Estética. Ed. Taurus, Madrid, 1980, pág. 25-26. 
ocurre, entonces, menos: son ambos antesala y trasiego del practicar conveniente que por definición decide al arte, y, por la misma regla, ambos son productivamente hostiles.

La experiencia del arte con respecto al mundo de vida es el resultado de una perversión: una parte siempre es hostil a la otra. Es ese sentido de ansiedad cognitiva del sujeto de la práctica lo que desafía al potencial cognoscente propio de la invisibilidad de la parte, por lo que en tal desafío ha de convertirlo en el blanco de sus experiencia de conocimiento. Dicha hostilidad, desafío y expectativas de conocimiento, nos hace suponer que en la producción artística sólo encuentra cultivo [encuentra margen de fertilidad, en el mismo sentido de positividad que de negatividad] una cierta forma de perversión -una cierta voluntad de perversidad- nacida entonces de una experiencia de desencanto, también de la oposición a la singularidad delatada de las partes puestas en relación en la propia experiencialidad (de aquello por ver y de aquello por ser), o aquello que da imagen al todo latente tanto de un lado como del otro de la nueva relación o que, de algún modo, sale de la esfera del interés conveniente para convertirse, cual si cambiara de naturaleza, en significación: en aquello a lo que damos acogida significante y en lo que de alguna manera -aunque sólo al inicio, porque de ello luego nos separamos, también convenientemente-, entonces fluimos. No es por otra cosa por la que artísticamente producimos obras, que no sea porque nos interesa.

Sin embargo, como otros tantos problemas relativos al conocimiento, en todo caso, especificado en la relación conocer-saber en los modos de prácticas artísticas, persiste la creencia de que el acto de conocimiento, e incluso de saber, tiene lugar por sí mismo y en sí, sin que intervenga ninguna sistematicidad. En cualquier caso, en ello parece persistir una muy vieja cuestión general, de índole interpretativa, a la que J.D. García Bacca da explicación en el primer capitulo de su Filosofía interpretativa 45 a través de la relación: Enajenación (natural): sentido (del filosofar griego), que viene a articular la idea de que el universo ha sido interpretado

45 García bacCa, juan David. Curso sistemático de filosofía actual (Filosofía, Ciencia, Historia, Dialéctica y sus aplicaciones). Colección Trópicos. Dirección de Cultura de la Universidad Central de Venezuela. Alfadil Ediciones. Venezuela, 1991. pág. 17-28. 
como un objeto de contemplación sensible, de modo que las acciones como tales no conllevan modificación alguna del mundo de vida en tanto dichas acciones son llevadas a cabo a través de un posicionamiento interpretativo enajenado. En ese sentido obra, como producto acabado, viene a ser el sentido que se le da al significado de conocer-saber, lo que de algún modo comporta una cierta autoreferenciación que con insistencia apunta al sujeto operacional enajenado como centrifugados único de las direcciones proyectantes tanto de significación como de sentidos, y en consecuencia, a la negación interpretativa de la modificación de aquello que como contemplación, que por supuesto no funda nada, es tan sólo un deseo.

\subsubsection{Idea de Idea de obra}

La fundación de la idea no descansa en la imaginación sino en los elementos discursivos porque estos últimos son cruciales en tanto objetivan el conformado cognitivo y filosófico de la idea de proyecto de $o b r a$. Esto es, que la dotan de conexiones no especulativas con la realidad, en tanto que el campo semántico (o los no lingüísticos) de cada uno de ellos se vuelve o son percibidos como más activos, como conectores de objetividad entre el supuesto [representación anticipada de lo posible] y la naturaleza cierta de la idea de obra. Es precisamente en esa percepción (similar al aforismo de Wittgenstein: los hechos del mundo no son, ni nunca serán 'todo lo que hay' $)^{46}$, en ese convencimiento intuitivo $\mathrm{y}$ dudoso, y como tal en las relaciones y conjeturas hecho-mundo, $\mathrm{y}$ ser-no ser donde, como sostiene George Steiner, "se funda la cultura". Se funda el principio de nombramientos que harán y consolidaran aquellas cuestiones -como las del incipit, sobre el comienzo de las cosas y de su fundamentación- próximas al tejido constitutivo de la idea. Es la intuición sobrevenida de esa percepción la que anima el tejido (el forjado) de nuestra identidad - ¿y acaso hay algo más profundo?- y

46 Aforismo derivado del convencimiento de los seres humanos de que la totalidad de los datos sensoriales y empíricos, al igual que la observación, las ciencias y el análisis racional que pueden ordenar y conectar tales datos, no es todo lo que existe. 
acentúa el tono de nuestra insatisfacción con respecto a la elección y las circunstancias en que se ha producido.

Según los métodos y el terreno que de algún modo se ha abarcado, el conocimiento procederá técnicamente hacia adelante (a un lado $\mathrm{u}$ otro) aunque a través de la búsqueda y ordenación de sus orígenes; de orígenes y fuerzas semánticas (o campos) a ser identificados, y de cuyos movimientos hacia lo primario de sus yacimientos de etimologías en relación directa con el modelo disciplinar de partida -también de los otros: constelativos y orbitativos, según las acotaciones de la investigación y de su sistematicidad- resulta la aproximación de unos respecto a otros, favoreciendo la visualidad y nitidez de sus límites y, en consecuencia, de la zona de acción de ese tan incordiado origen o principio entonces conveniente por su potencial objetividad. Damos por hecho que la condición de principio (del incipit en cuestión) del elemento discursivo elegido, constituido en la elección de ese punto o señal desde donde buscar y desde donde incluso nombrar-, la conforma el conjunto de sus radiaciones de fondo y el comportamiento de los fragmentos de sus etimologías, simbolicidad o semanticidad, localizados en la expresión, en la palabra y en el concepto. Un poderoso ejemplo de aquello que puede haber en el radio semántico de las palabras lo podemos encontrar, tanto en su pasado como en su proyección en el tiempo, en el término incipit y su devenir contemporáneo en la palabra incipiente.

Incipit: el inicio, lo primero ya sido, lo que funda de raíz la cosa.

Incipiente: en proceso de conformación; progresión formativa entre un desde y un hasta preciso.

\subsubsection{El objeto artístico no es significativo por ser universal}

El objeto artístico no es significativo por ser universal, sino más bien puede considerársele universal porque es significativo gnoseológicamente. Esta afirmación basada en la distinción que hace 
la Teoría del cierre categorial 47 a la noción de universales de la teoría aristotélica de los objetos, nos sirve para abrir una cadena de redefiniciones convenientes en relación a la formulación, producción y pensamiento del objeto artístico. Cadena de redefiniciones que nos permitirán articular el protocolo necesario para situarnos en la antesala teórica de dicho objeto con tal, de dotarlo de las conexiones idóneas de objetividad. La más significativa de esas redefiniciones tiene que ver con el desplazamiento del centro de interés del objeto y del artista, hacia los sujetos gnoseológicos (espacio social, espectador o público con su respectiva metodología de observación y de análisis), de modo que sería la escopia propiamente crítica, en cuanto voluntad de conocimiento [condición conocer-saber] la que otorgaría lugar e intensidad significante -a través de propio protocolo de conocimiento- a todo aquello producido por el artista.

En ese sentido una obra individual, comenzaría a serlo sólo a través de los protocolos y las operaciones gnoseológicas -de conocimiento, epistemológicas, de representación y de crítica- activadas por el conjunto de los sujetos gnoseológicos en los límites necesarios para dar cuenta de ella. Esto, como es evidente, presupone la existencia de una cierta interacción gnoseológica-protocolar entre el sujeto gnoseológico artista y la comunidad cognoscente, en el sentido de que necesariamente tienen que compartir, como punto de arranque, las mismas formas de conocimiento.

Ahora bien, según la teoría del cierre categorial, el sujeto gnoseológico ${ }^{8}$ es un individuo de una clase distributiva (en nuestro caso espectadores o público) formada de elementos intercambiables por

47 Bueno, Gustavo. Teoría del cierre categorial. Volumen 1. Introducción general. Siete enfoques en el estudio de la ciencia. Ed. Pentalfa, Oviedo 1992.

48 "Pero el sujeto gnoseológico es, a su vez, un individuo de una clase distributiva (la clase de los historiadores, que, a su vez, forman una subclase de otras clases sociológicas del presente). Una clase formada de elementos intercambiables. Por consiguiente la reliquia de referencia, aun cuando estuviese dotada de unicidad absoluta, debería tener una forma de la universalidad distributiva conjugada (Por así decir, la reliquia no es la piedra Rosetta en su masa física individualizada. Sino también las copias que de ella se hicieron ya a raíz de su descubrimiento). Y la tesis equivale a una propuesta metodológica en el sentido de la relativización del concepto de reliquia o monumento como 'hecho geográfico'". BUENo, GUSTAVo. El individuo en la historia, Universidad de Oviedo, 1980. Pág. 73 
lo que la obra de referencia dotada de unicidad absoluta, debería tener la forma de la universalidad distributiva conjugada, lo que introduce una cierta relativización del hecho artístico como individualizado en tanto quiere decir que la obra tal cual no la constituye solamente su masa física individualizada ni el conjunto de direcciones referenciales, sino también el conjunto de extensiones valor, de copias valor que de ella devienen no sólo tras su puesta en circulación sino desde el momento mismo del conformado de su idealidad. A decir, el objeto de conocimiento del arte necesariamente atraviesa la peculiaridad de unas formas y protocolos de saber que de ningún modo pueden ser ignorados y que van desde las circunstancias de la constitución de la idea de idea de proyecto, que conlleva el diseño de su innovación y de su interpretación, hasta las circunstancias de socialidad de su puesta en circulación.
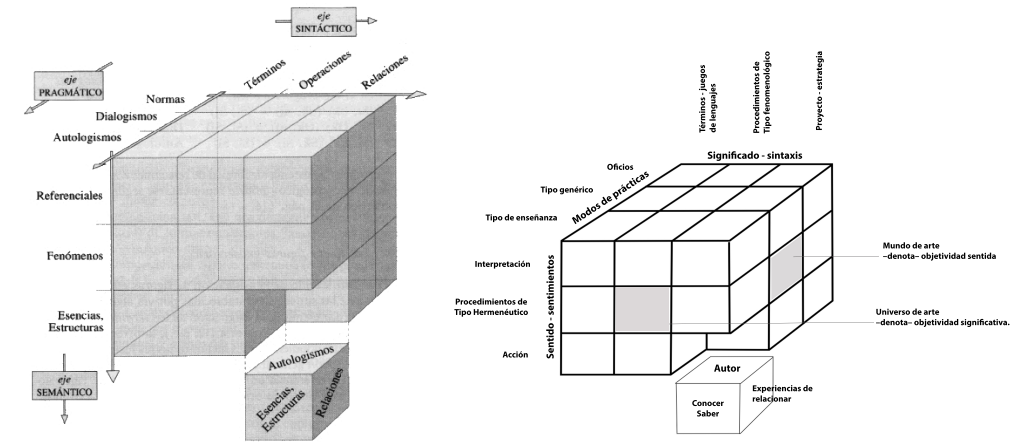

Figura 8: Cuadro de equivalencia del modelo de Cierre Categorial (de Gustavo Bueno) y en modelo de relación Universo Arte-Mundo arte 


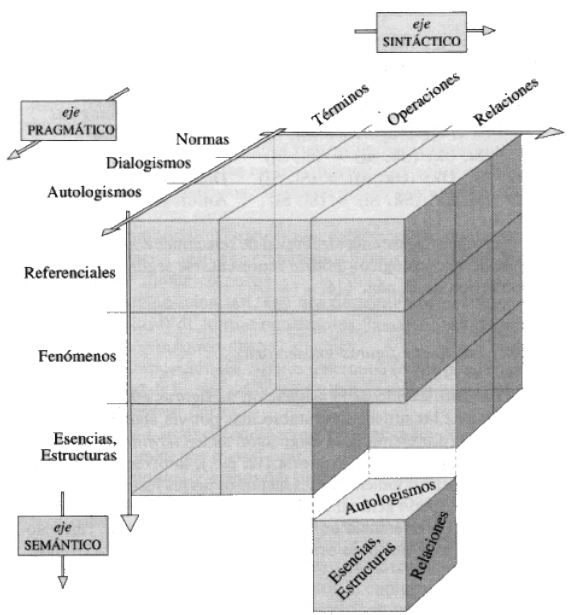

Figura 9: Teoría del cierre categorial de Gustavo Bueno

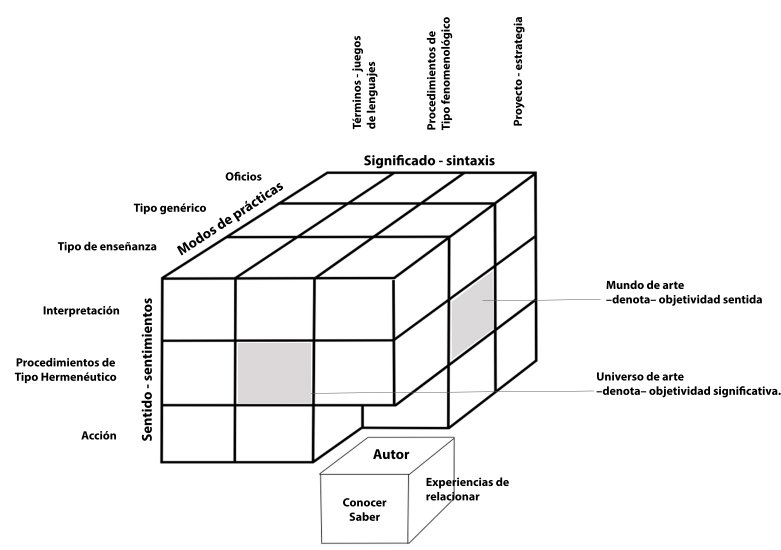

Figura 10: Esquema de la relación Universo Arte-Mundo arte. 


\section{6 ÚTIL, ENTIDAD, SUYO PROPIO}

Nuestro interés instrumental y reflexivo no se basa en la reducción del principio de la idea de proyecto de obra estrictamente al lenguaje, sino más bien presta atención y pone acento a la cuestión de que es a través de éste, o en relación con él, que ese principio es comprendido. La base de nuestra metodología, primero determina la naturaleza de los entes, útiles o elementos que sirven o han de servir para algo, si bien ese hipotético algo tiene al igual que el propio elemento -útil o ente-, una naturaleza siempre teórica. En ese sentido eso que llamamos elemento discursivo (primario o secundario) hereda el "para" heideggeriano, según el cual, de la estructura que tiene se determina una referencia de algo a algo, y por lo mismo -con una potencia similar al "sirve para" propia del útil cuando remita a algo- el elemento discursivo potencial también un remitir a algo, o un estar remitido de algo, que en cualquier caso apunta a un discernir relacionado cuya especificidad pone acento [a esa complicada ontología] en la dimensión paisaje, en la condición entorno, y en el supuesto contexto, en tanto guardan en conjunto una relación por adscripción: el primero indica su ser conveniente respecto al segundo y, el segundo, a su vez lo indica respecto al tercero, y así, hasta el límite propio de lo constituido como idea de obra, continua manifestándose una cadena también conveniente de otras no memos importantes adscripciones.

Un ejemplo de relación por adscripción que en principio nos sirve, aunque fuera del marco constitutivo de la obra, es el de "la pluma en relación con la tinta, la tinta en relación con el papel, o de la pluma, la tinta y el papel en relación, todos, con la carpeta", de Lucio Fidel Obando $^{49}$, que es utilizado para el análisis del ente en la concreción óntica de la obra de Heidegger. Un comportamiento simplificado lo podemos apreciar bien en el esquema de Philip Wheelwright o en los diagramas iniciales del plano de triangulación operacional, aunque, eso sí limitados siempre por el perfil del tipo de problematización

49 OBAND GUARNZ, LUCiO Fidel. “La noción de útil y obra de arte según Martín Heidegger” publicado en Escritura y Pensamiento, Año 5, No 9, 2002. Perú. Pág. 51. Ed. online: http:/ / tinyurl.com/l7ypvp2 [Fecha de consulta: 23 de diciembre de 2010] 
que pongamos en juego. Sin embargo, en el caso de las adscripciones entre elementos discursivos, supuestas por tanto a mano en el proceso de análisis, reconocimiento y constatación previo a la articulación de la idea de idea de obra, las propias adscripciones se tornan algo más complejas que las relación de adscripción entre simples útiles. En esta ruta óntica, dicha complejidad radica en que a diferencia del útil (el sirve para algo), como lo más cercano y sin cariz teórico, la observación de la relación de adscripción entre elementos discursivos parte de un principio de determinación proyectante de significados, y por tanto, de una cierta cualificación: principio entonces de prefiguración de la complejidad o no de la naturaleza de idea de obra, que desde ya anticipa doblemente las opciones de manejo, uso, y andares, según la ruta cognitiva trazada, bien profundamente teórica, bien hábilmente manual. En todo caso nuestra cadena de adscripciones, devenida de la relación entre elementos, lo que hace es propiciar la potenciación del sentido teórico de toda aquella multiplicidad de cosas [que directa o indirectamente] entran en dicha cadena de relaciones, y por lo tanto las impulsa hacia una hondura y plano necesariamente ontológico: observación, contemplación y punto de vista, o lo que es lo mismo una perspectiva ontológica. El saber, en cierto sentido, del elemento discursivo en cuestión ha de convertirse en saber real y consciente, puesto que se tiene que conocer como se le maneja con tal de dotar de objetividad a la idea de obra. Es a ese "conocer como se le maneja" al que, entre otras cosas, nos introduce la definición de partida del plano de triangulación operacional. 


\subsection{PLANO DE TRIANGULACIÓN OPERACIONAL}

Es el plano de partida, o de arranque, que dota a nuestro principio problemático de investigación -desde el inicio mismo-de la objetividad básica necesaria para poder lanzar la (o las) estrategias-problemas oportunas para alcanzar la armazón de la idea de proyecto $5^{\circ}$.

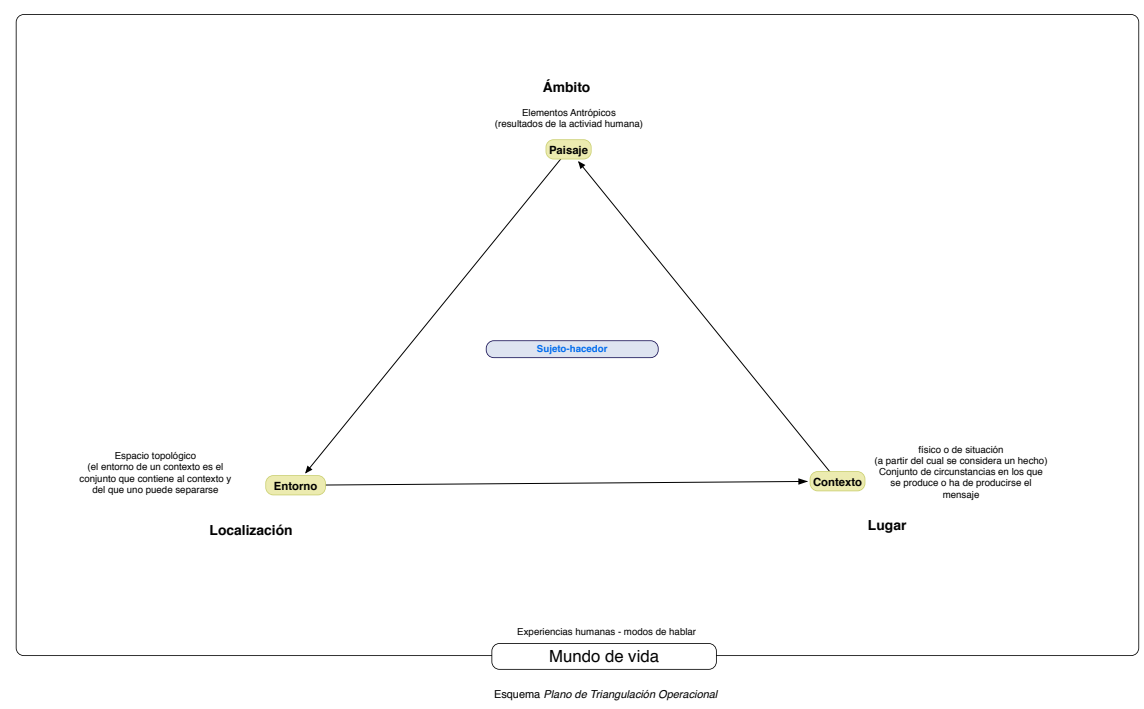

Figura 11: Esquema plano de triangulación operacional

Plano de triangulación operacional desde cuyo análisis podrán deducirse los tres flujos fundamentales de operacionalidad posible en relación al proyecto de idea de obra (las partes cognoscente o de problematización), donde aguardan las tres naturalezas posibles desde las que trazar la idea de proyecto, y en consecuencia (entonces sumergidos en un necesario plano de conocimiento), desde donde debería deducirse la

50 En éste nivel de la metodología entendemos «idea de obra» como un constructo, y en tal sentido, como algo intangible que necesita ser deducido, estructurado y montado, a través de un proceso determinado de categorización para que a su vez pueda ser interpretado, representado o activado. 
naturaleza proyectual de la obra: Una de esas naturalezas tiene un carácter representacional, la otra un carácter espacio-temporal, y la tercera, tiene una naturaleza y carácter necesariamente mixto y por lo tanto, es una combinación particularizada de las dos proyeccionalidades y caracteres albergadas en las dos anteriores.

\section{Philip Wheelwright y el plano de triangulación operacional.}

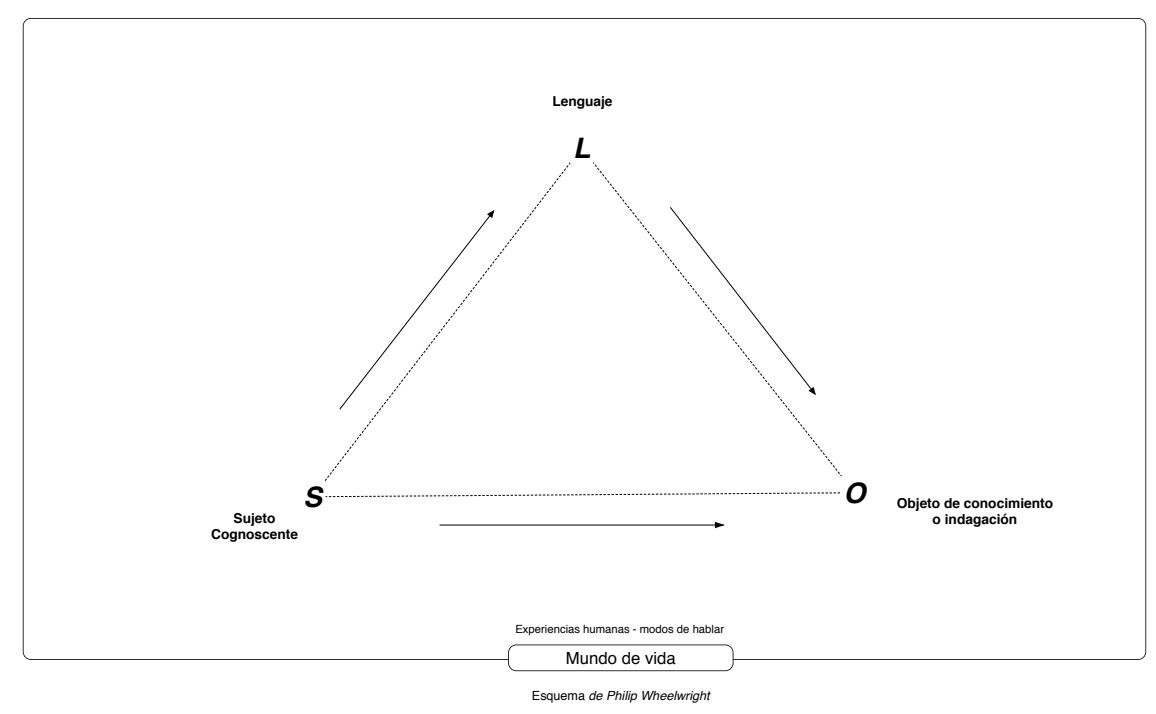

Figura 12: Esquema de Philip Wheelwright

Como en nuestra estructura metodológica el plano de triangulación operacional constituye el punto de partida, dicho plano no puede serlo si no es por, o como consecuencia, de una necesidad cognitiva, de un esfuerzo de cognitividad. Cumplido dicho condicionante, impulsa la primera puesta en relación de la cadena de detecciones que necesariamente han de producirse de cara a la formulación de la idea de obra o de proyecto de obra. El plano de triangulación operacional funciona como la esquematización del comportamiento de los valores saber-conocimiento en la relación, por un lado, al mundo de vida, y por el otro, a la problemática de la formulación (ordenación categorial, etc.) 
de la idea de proyecto de obra.

Ahora bien, ¿de dónde proviene, en términos teóricos, la formulación de una figura operativa de la índole del plano de triangulación operacional y qué sustenta? A nuestro plano subyace el esquema de triangulación que Philip Wheelwright ${ }^{11}$ hace para representar el comportamiento de lo que él llama «estructura tripartita» (sujeto, objeto y medio lingüístico) de interpretación de la realidad en oposición al dualismo cartesiano cuya forma última es expresada en la relación de oposición "lo subjetivo frente a lo objetivo". En todo caso, como límite histórico retrospectivo deberíamos situarnos en el momento mismo (finales del siglo xIX) de la apertura de occidente a los modos de pensamiento y expresión orientales $^{52}$, y, consecuentemente a la puesta en crisis -como limitación-, de la perspectiva lingüística occidental una vez que publicados, por ejemplo, los cincuenta volúmenes de los Libros Sagrados de Oriente o el Tao Te Ching, donde se ofrecían los Brahmanas, los Puranas y el Sutra de Diamante, por el impacto revolucionador que necesariamente habían causado en las consideraciones semánticas de occidentales con base en los siglos XVII y XVIII, y, en en ese sentido, centradas en el latín, y que filólogos como Friedrich Max Müller exponen al pensamiento occidental a través de la ordenanza de sus traducciones al inglés. Al respecto $\mathrm{P}$. Wheelwright comenta:

"El análisis lockiano de la "sub-stancia; la comparación Kepler de anima y vis como expresiones alternativas para designar la fuerza que hallamos en la naturaleza, y el tratamiento por Schopenhauer del significado de los conceptos abstractos, evidencian tanto la precisión como el limitado alcance que permite una consideración de los problemas semánticos guiada por el latín. Incluso cuando pensadores tan imaginativos como Vico, Hamann y Herder trataron de ensanchar la perspectiva ocupándose de las relaciones entre la lingüística y la mitología, se vieron coartados por el hecho de

51 Wheelwright, Philip. Metáfora y realidad. Ed. Espasa-Calpe. Madrid, 1979. Pág. 26

52 Ibídem., pág. 22-27. "Fue en este periodo cuando un eminente grupo de Filólogos, espoleados hígados por el saber y la energía del oxoniense Friedrich Max Müller, consiguieron sacar a la luz, ordenar y traducir al inglés los grandes tesoros literarios y religiosos del Antiguo Oriente". 
que ambos términos de comparación se hallaban casi totalmente confinados a los materiales greco-latinos. Los recientes explorados mitos y relatos folklóricos de los indios norteamericanos, los incas y los isleños de los mares del Sur no habian encontrado todavía lugar conveniente e inteligible en la ciencia, aún en mantillas, de la investigación mito-semántica." 53

Es precisamente en la diferencia radical encontrada en la expresión Oriental a través de los modos filosóficos de investigación, a su vez expresados en un lenguaje -más bien dos, uno escrito y otro habladocuyo modo de construcción y de funcionamiento para nada coincidían con las infraestructuras semánticas del pensamiento occidental, lo que, a principio del siglo $\mathrm{XX}$, pone de manifiesto la necesidad de la entrada en juego -en el sentido de una definición clarificadora- de nuevas perspectivas semánticas, en las que de algún modo los aportes derivados de las direcciones emprendidas por la antropología ${ }^{54}$, la neoclásica ${ }^{55}$ y la filosofía ${ }^{56}$, ya comenzaban a admitirse como fundamentales, sobre todo en la disposición de situar el problema del lenguaje en el centro de los estudios filosóficos. Esto es: que la consideración del lenguaje como un medio necesario para el desarrollo y la comunicación del pensamiento filosófico, se ha añadido la también consideración de que no sólo

53 Ibídem., pág. 23.

54 Las investigaciones de Lévy-Bruhl (L'expérience mystique et les symboles chez les primitifs, París, 1938), referidas a las peculiaridades mentales y la lingüística de los llamados primitivos; los ensayos de A. E. Crawley (The Mystic Rose: A Study of Primitive Marriage, 1923), de la 'holofrase' como característica del lenguajes y del pensamiento de las tribus indias norteamericanas y otros pueblos pre-civilizados; o las insistencias de Malinowski y Lord Raglan, entre otros, sobre la relación entre mito y ritual, y por extensión entre lenguaje y ritual.

55 En filología clásica, las investigaciones de Francis M. Cornford (From religion to Philosophy, Longmans, Green, 1912), reflejadas en las traducciones de Platón como impulsoras de la reconsideración de Mito y la doctrina en relación a los nuevos descubrimientos antropológicos y las nuevas técnicas de análisis semántico.

56 Ernest Cassirer, quien desde su postura neokantiana enfoca los estudios de la realidad por medio del método del análisis categorial (Philosophy of Symbolic Forms. Yale University Press, 1953-1957) sobre las interrelaciones entre conciencia sensorial, el juicio mental, el uso del lenguaje, mito y arte. 
es un medio para dicha comunicación, sino uno de los ingredientes fundamentales de ese pensamiento.

Las consecuencias del desplazamiento del problema del lenguaje al centro de los estudios del pensamiento filosófico cobran valor de evidencia precisamente en «otro desplazamiento» de índole trascendental en el comportamiento, desarrollo y evolución del pensamiento occidental hasta la actualidad. En todo caso, eso que nosotros denominamos «otro desplazamiento» Philip Wheelwright lo describe de la siguiente manera:

"El tradicional dualismo cartesiano de espíritu y materia, o, en sus formas últimas, de los subjetivo frente a lo objetivo, que ha dado forma y dirección a gran parte del pensamiento filosófico a partir del siglo XVII, ha comenzado a ceder en muchos aspectos ante una estructura tripartita, en la que sujeto, objeto y medio lingüístico desempeñan papeles irreducibles e intercausales en la formación de lo que, a falta de un nombre mejor, podemos llamar realidad. La vieja díada epistemológica está siendo reemplazada en buena parte de la filosofía contemporánea por una tríada. Si bien llamamos $S$ al sujeto cognoscente, $L$ al lenguaje (en el sentido más amplio posible) mediante el cual $S$ lleva acabo de expresión simbólica, y O al objeto del conocimiento o la indagación, la estructura básica de cualquier situación, en la medida en que los seres humanos la conocen o inquieren acerca de ella, puede representarse mediante este esquema".57

En cuanto a su comportamiento, nos dice:

"Lo que aquí conviene subrayar es que ni S ni L ni O pueden ser concebidos como existencias aisladas, aparte de su interacción con los otros dos factores. Por supuesto, en una determinada situación, es frecuente poner mayor énfasis y atención en uno $u$ otro de esos factores, de modo que la presencia e influencia implícita de los otros dos pasan inadvertidas. Así ocurre, sobre todo, cuando investigamos un objeto al que nos referimos como 
«algo existente» y hacia el que mantenemos una «actitud puramente objetiva». La altura de un edificio, por ejemplo, parece ser lo que es de manera objetiva, independientemente tanto de las actitudes subjetivas para con ella como del lenguaje en la que se expresa. $Y$ es muy cierto que una vez el problema -la altura de un edificio- ha sido claramente comprendido y formulado, la determinación de esa altura tendrá ya un carácter puramente experimental y objetivo, sin que 1000 objetividad ni la expresión lingüística sean de importancia esencial."

Es entonces en la didáctica de la «estructura tripartita» (sujeto, objeto y medio lingüístico) de Philip Wheelwright en lo que, de algún modo, nuestro plano de triangulación operacional se fija de manera general, pero sobre todo en la capacidad de representar las formas de inquirir las relaciones entre las cosas: en nuestro caso el comportamiento y la complejidad de las entidades mínimas (los elementos discursivos) en la formulación pertinente de la idea de idea de proyecto de obra.

Por otro lado, a los elementos discursivos se les presupone una cierta función de expresión (latente). Se les presupone en un nivel (tan profundo como sea necesario imaginarlo en la mismidad del plano de triangulación operacional) el cual revela la multiplicidad de sus fragmentos, de sus fragmentos de operacionalidad bien interpretativas (ya que dan pie al desciframiento, en el plano de triangulación operacional, de aquello que oculta y que a la vez manifiesta. En dicho nivel la idea obra, en tanto que aún carece de articulación necesaria y porque en ese mismo sentido no lo es, no puede considerarse como una unidad por ser de forma inmediata, como tampoco puede ser considerada como homogénea porque todavía no es un constructo, y menos como una unidad cierta. Así el primer motivo de análisis que potencia el plano de triangulación operacional es siempre el de dotación de un principio de historia (no en el sentido de un "ya dicho" 58 con

58 Foucault, michel. Arqueología del saber. Ed Siglo XXI. Madrid, 2009. (traducción de Aurelio Garzón del Camino). Pág. 38. "El primer motivo hace que análisis histórico del discurso sea búsqueda y repetición de un origen que escapa a toda determinación histórica; el otro hace ser interpretación o escucha de un "ya dicho" que sería al mismo tiempo un "no dicho". 
límites, sino en el de dotación de objetividad) a la problemática entrada en cuestión.

Son los elementos discursivos, a partir del plano de triangulación operacional, irruptores de acontecimientos por lo que ante y durante su análisis no nos devuelven hacia la lejanía y oscuridad de sus orígenes, sino más bien (como posibilidad de apertura o de irrupción) al potencial tratamiento de sí como juegos de instancias: o sea, como bases propias para todo tipo de aventura de articulación, como los elementos necesarios para la dilucidación del o de los constructos "idea de proyecto de obra". Respecto a ello, la inquietud que ante su descubrimiento tiende a producirse, no debe dar pie a la recusación de su aceptación, puesto que más que cualquier otra cosa, nos muestran que, como tal, no pueden ser deducidos naturalmente en tanto que son (y no otras cosas) construcciones cuyas reglas hay que conocer, hacerlas evidentes, y en todo caso, controlarlas a base de la formulación de preguntas al estilo o del tipo de las que Foucault formula en "Las unidades del discurso"59: ¿Qué son?, ¿Cómo definirlos o limitarlos?, ¿De qué articulación son capaces?, ¿A qué subconjuntos pueden dar lugar? o ¿Qué fenómenos específicos hacen aparecer en el plano análisis?

El plano de triangulación operacional de nuestra estructura metodológica, una vez entendido como punto de arranque y de dotación de objetividad, entonces se libera como un dominio (inmenso), constituido por el conjunto de las enunciaciones efectivas (las propias de las construcciones humanas y del mundo de vida), la dispersión de sus acontecimientos (mostrados a sí como cognoscentes) y el potencial, como instancias, que es propio de cada uno. Dominio cuyo material, que habrá que tratar en su neutralidad primera, es una multiplicidad de acontecimientos -ha constatar- en el espacio, o desde el espacio, del plano de triangulación operacional.

Es preciso renunciar a todos esos temas cuya función es garantizar la infinita continuidad del discurso y su secreta presencia en el juego de una ausencia siempre renovada."

59 Ibídem., pág. 33-45. 


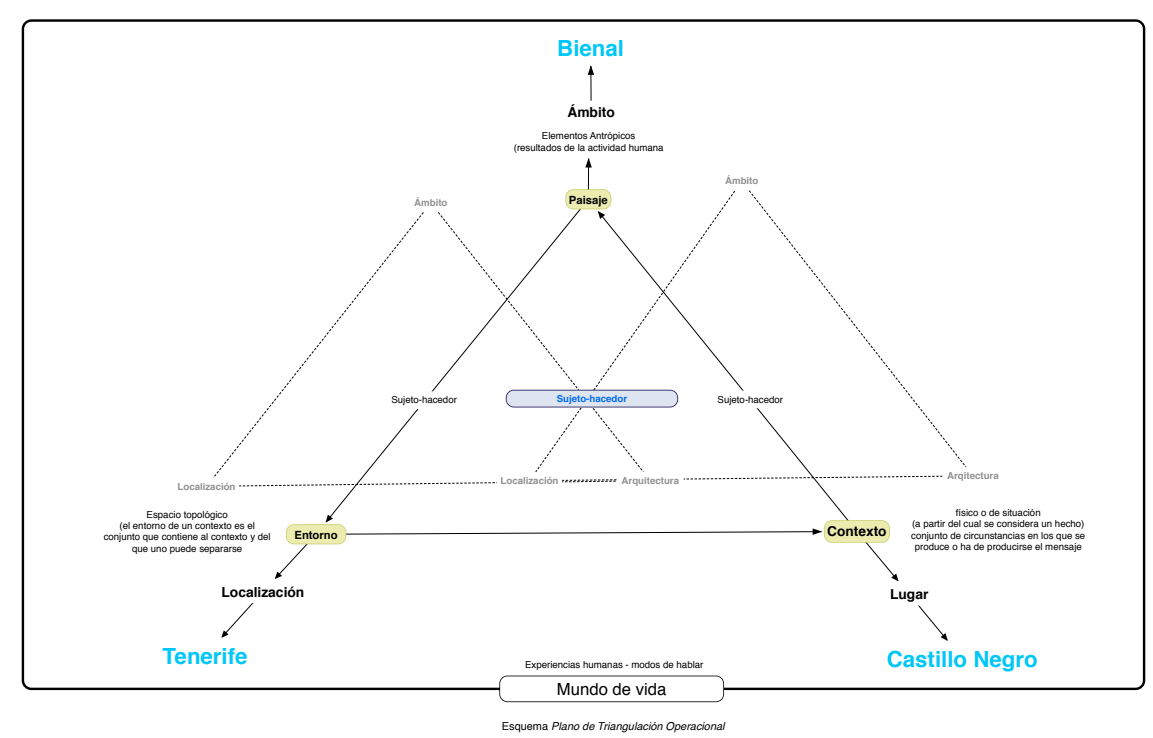

Figura 13: Plano triangulación operacional de partida (1)

En cualquier caso, el análisis a partir del plano de triangulación operacional viene a decidir en conjunto -en los términos de marco conceptual general- todas esas unidades básicas de las que afirma J. Claramonte en su "Preliminares a una Estética Modal"6o: "son siempre determinadas intensidades específicas, determinadas modulaciones de las relaciones que se establecen entre los artistas, los espectadores y el medio en que todos ellos se hallan, y esto es así de modo tal que incluso cuando "la obra" se ha acabado esta puede rememorarse en función de lo que ya podemos llamar su identidad modal: su específica consistencia a la hora de definir y articular un conjunto de relaciones", que nos permiten pensar el conjunto en una retroproyección relacional, tanto la producción como la recepción estética de la obra.

6o Claramonte, JORdi. Preliminares a una Estética Modal, (Entrada, sábado, 31 de mayo de 2008). http://jordiclaramonte.blogspot.com.es/2008/o5/estetica-modal.html 


\subsubsection{El sistema: La posibilidad de pensarlo}

Universo del arte es, pues, -denota- objetividad significativa. Mundo del arte es, pues -denota- objetividad sentida. El primero, Universo del arte, por denotar y proyectar el significado es de tipo fenomenológico; en cambio el segundo, Mundo del arte, por denotar y proyectar el sentido es de tipo hermenéutico. En cualquier caso Universo del arte y Mundo del arte constituyen una unidad denotativa de proyección de significado y de sentidos. La objetividad significativa de las individualidades artísticas, aquello que se cree da a ellas valor de pertenencia y función intensiva ${ }^{61}$, en términos históricos, es una abstracción -aunque no por ello menos afectiva- porque su verdad, contenido y textura es neutral e independiente de que alguien la note como evidente. El término abstracción, al que hemos apuntamos en líneas anteriores, es usado (como anclaje conveniente) en el sentido que Gustavo Bueno le imprime en El individuo en la historia" ${ }^{62}$ o sea, de "desconexión de los términos objetivos respecto a las subjetividades operatorias que le confieren significado histórico". A decir, la ruptura de relación directa, o de funcionamiento sistemático, entre aquello que condiciona tanto la operatividad como el término objetivo en relación a la obra (la objetividad física y conceptual corresponde a ella) respecto de quienes la producen -desconexión por tanto del sistema obra respecto al sujeto operatorio (el artista). Esto presupone que una vez concluida la obra, el artista deja de tener y ejercer influencia alguna, sobre todo de tipo gnoseológico y no tanto del tipo semántico, respecto a ésta, y también que la objetividad y lugar funcional de la obra sólo se manifiesta si dicha objetividad y lugar funcional forman parte de un tejido socializado y análogo de otras obras, de modo tal que la argumentación sobre la inmediatez, importancia y valor de significado de la obra, una vez acabada, es más bien una insistencia y justificación

61 garcía bacca, JuAn David. Curso sistemático de filosofía actual (Filosofía, Ciencia, Historia, Dialéctica y sus aplicaciones). Colección Trópicos. Dirección de cultura de la Universidad Central de Venezuela. Alfadil Ediciones. Venezuela, 1991. pág. 17. "Al sentido llama la lógica moderna función intensiva".

62 bueno, gustavo. El individuo en la historia. Discurso inaugural del curso $1980-81$. Universidad de Oviedo, 1980. Edición online: http://tinyurl.com/kgrl95l [Fecha de consulta: 1 de febrero de 2012] 
de carácter empírico, o, en el sentido de Carnap ${ }^{63}$, un "modo material de hablar".

El hecho de que alguien pueda imaginar, proyectar y producir una obra quiere decir -al menos lo supone-, que también en relación a otros muchos sujetos se revela la posibilidad de que de igual manera algo similar pueda ser imaginado, proyectado y, en el caso de la cosa obra, producida.

La universalidad supuesta en la individualidad de la obra sólo puede tener lugar si forma parte de un sistema de iguales; a saber, la posibilidad distributiva de la misma en un espacio social constituido para su circulación reflexiva por los sujetos gnoseológicos, implica la extensión de esa posibilidad al espacio de los propios sujetos como partes del propio ámbito de la obra (espectador o público con su respectiva metodología) para dar cuenta refiriendo a la semántica del campo artístico de que como tal, la obra, entonces enclasada, lo es. Ocurre, como apuntamos al inicio, que es precisamente en esa fisicalidad (dicho esto en términos del suyo propio que de algún modo permite ser diferenciada) donde tiene lugar la abstracción, la desconexión del sujeto operatorio [el artista] tanto que su devenir sólo cobra potencia al margen de este último, es decir, a cargo de una distancia y espacio social que esté dispuesto a asumir su circulación reflexiva y crítica, entonces como reinterpretación a partir de sujetos gnoseológicos. Aquello que de algún modo confiere valor de objetividad y significado a la obra -lo que la individualiza y vuelve universal- tiene lugar como una relación entre los términos de objetividad (fisicidad y sujeto artista) y el espacio social que la acoge, la crítica y la piensa. En cualquier caso, toca al "hacedor" (al artista) dotar de todas esas conexiones necesarias a su propio producir, es a él a quien corresponde a través de las acciones de organización de su conocimiento respecto a las cosas con las que pretende operar o con las que guarda relación, dotarlas de objetividad, en tanto que es la única forma de producción de saber.

63 CARNAP, RUdolf. Filosofía y Sintaxis Lógica. Universidad Nacional Autónoma de México, México, 1963. 


\subsection{METOdología Y MÉtodo: sujetos A UNA BASE IdEOlógicA}

Toda forma de observación, de reflexión o de investigación está sujeta a una metodología y a un método, como del mismo modo Metodología y Método están sujetos a un componente ideológico (a una base) que necesariamente deviene más o menos reforzado a razón de la potencia crítica, la eficacia, la objetividad y la elección técnica que, Metodología y Método, son capaces de hacer circular en torno a su objeto de estudio. Por ejemplo, la nueva retórica, concentra sus fuerzas críticas en las técnicas discursivas relacionadas con las nuevas teorías argumentativas herederas de la retórica aristotélica, sin embargo esas fuerzas críticas proyectan sus resultados hacia un ámbito práctico específico, "que tiende a provocar o acrecentar la adhesión a las tesis que se les presentan para obtener un acuerdo, según los tipos de auditorios" -en esto consiste propiamente, junto al razonamiento Dialéctico en oposición a la Lógica formal, la herencia aristotélica. Bourdieu ${ }^{64}$ se refiere a la cuestión metodológica como aquello que supedita la necesidad de elegir la técnica [adecuada] en función de la naturaleza del tratamiento que cada técnica impone a su objeto. En el lado crítico, en su “¿Es posible la enseñanza del arte?, Luis Camnitzer lo señala de otro modo:
"En el caso de la enseñanza artística, el problema del desaprendizaje es mucho peor que en las otras ramas del conocimiento. Las dudas, nebulosidades y timideces no son solamente individuales sino culturales y colectivas. Al artista, por ejemplo, se le pregunta: “¿Ud. qué hace?" y el artista contesta: "Yo pinto al óleo". A la pregunta que plantea un: "qué" se le contesta con un "como". Lo que bajo otras circunstancias se percibía como un diálogo de sordos o, mejor, un diálogo que no se cumple, en este caso es aceptado por ambas partes como un intercambio satisfactorio. El interrogador cree que ahora sabe más sobre el arte del artista. El artista cree que con la información técnica justificó su actividad. Pero un científico

64 BOURDIEU, P. Y WACQUANT, L. "Transmitir un oficio"; "Pensar en términos relacionales" y "La duda radical", en: Respuestas para una antropología reflexiva. Ed. Grijalbo, 1995. México. 
nunca contestaría: "Yo me paso mirando a través de un microscopio electrónico". Tendería, en cambio, a describir un proyecto: "Me dedico a la investigación de estructuras moleculares" o cosa por el estilo. No utilizaría el instrumento o la técnica empleada, para validar su actividad." ${ }^{6}$

Es precisamente la correlación entre metodología y método lo que fundamentalmente los separa. Por un lado, el método, en su singularidad, afirma la potencia de elegir adecuadamente la técnica con la que ha de abordarse el problema, evidenciando su capacidad de modificarla según la naturaleza de dicho problema. Por otro, la metodología estudia la afirmación de la potencia de elegir la técnica adecuada que el método en su singularidad de algún modo pone en marcha.

\subsubsection{Método, metodología, procedimiento}

1- El método -también podríamos decir procedimiento- de detección de los elementos discursivos, debería ser entendido como una herramienta en paralelo y no como una estrategia de sustitución de ninguna otra herramienta anteriormente diseñada, aunque el pretexto de su puesta en marcha tiene que ver con las carencias supuestas en el modelo standard de enseñanza del arte. Desde el principio mismo hemos tenido que correr el riesgo de una construcción terminológica si no inédita al menos problemática, arriesgada e ilusionante para dicho empeño.

Ahora bien, qué nos ha llevado a reflexionar sobre la posibilidad de articulación de una metodología para la enseñanza o aproximación a la construcción [a la armazón consciente de las partes] de la idea de obra, la idea del proyecto, la idea de idea de proyecto de obra. Durante años hemos observado las formas de acercamiento de los profesores de Bellas Artes a la conformación de los ejercicios que luego serían incorporados a los programas docentes, y como tal, al diseño disciplinar

65 CAmnitzer, Luis. Arte y Enseñanza: La ética del Poder. Colección Apuntes de Casa de América. Ed. Casa de América, 2000. Madrid 
de la académica y por extensión a alguna forma de proyección de un modo de práctica artística. También durante esos mismos años hemos descubierto que el principio formativo del conjunto de bloques de contenidos o de ejercicios específicos (según el principio disciplinar o de género) tiene, o mejor dicho incurren en el error [de origen] común de la desatención de cuestiones relativas a los principios formativos (la cuestión del comienzo y los vínculos) de los elementos, formatos, zona de la realidad, tomados en cuestión para la implementación del ejercicio. Hemos constatado que -tal cual el espíritu de una época-, el conjunto de los esfuerzos y proceso de conformación de los ejercicios académicos, tanto en las asignaturas prácticas como en el conjunto de las asignaturas teóricas, basan su conformación en algo que Luis Camnitzer introduce -de forma crítica, claro está- en su ensayo "Codificar y decodificar"66, y que denomina modos clasificatorios de reconocimiento del valor contributivo del producto; modos clasificatorios, en este especifico caso, del producto académico, y en el suyo propio, referido al producto artístico.

2- Éste modelo de clasificación no es un modelo cuya puesta en práctica encaje con algo, digamos académico, científico incluso consciente, esta forma de conformación, insistimos es empírica, y en el peor de los casos fruto de la vulgarización, desde su origen mismo, de esa forma de clasificación y su uso tal cual, es aquí donde comienza eso que denominamos intentos de anticipación de la representación de las cosas, es aquí donde entonces empieza a proyectarse de forma confusa, en tanto lo hace -proyecta su conformación- no en la objetividad de un principio conocimiento sino en una intuición, y todo al margen de una estructura metodológica, una didáctica o una herramienta pedagógica que pretende ser objetiva.

Ahora bien, eso que hemos decidido llamar "intentos de anticipación de la representación de las cosas" puede, de algún modo, explicar el fondo de desconocimientos sucesivos que se esconden detrás de ese modelo de organización, planificación y de clasificación, detrás de esa

66 camnitzer, Luis. Arte y Enseñanza: la Ética del Poder. Colección Apuntes de Casa de América. Ed. Casa de América. Madrid, 2000. El ensayo Codificar y decodificar fue publicado anteriormente en el año 1971. 
forma de articulación de un simple ejercicio académico o el desarrollo de un proyecto artístico. El modelo de clasificación de la contribución de la cosa según su producto final omite de forma absoluta -porque deja fuera o no introduce ninguna reflexión sobre ello- toda conexión o disposición vinculante a los procesos formativos y los modos perceptivos anteriores al conformado de la cosa tal cual. Por tanto, parece haber un problema con el concepto de comienzo, un problema con el 'incipit' del que habla George Steiner ${ }^{67}$ en relación al convencimiento de los seres humanos de que ni la totalidad de los datos sensoriales, ni los producidos a través de la observación, en todo caso científica, no puede garantizar la afirmación de que ello es todo lo que existe.

67 STEINER, GEORGE. Gramática de la creación. Ediciones Siruela. Traducción de Antoni Alonso y Carmen Galán Rodríguez. Barcelona. 2011. pág. 20-34. 


\subsection{CARÁCTER EXHAUSTIVO DEL MÉtodo}

El método de detección de los elementos discursivos, por su carácter, pretende ser exhaustivo. Lo pretende en tanto que de manera general remite todos los comportamientos de las figuras o las estructuras gramaticales iniciales a un estado de categoría de primer orden -del que los mediólogos dirían esencia originaria- al estilo de las palabras, el deseo, el trabajo, etc. Es precisamente esa conversión, ese nuevo estado de ser categoría, de ser ya otra cosa, el que potencia la capacidad de transmisión, cohabitación o de superposición de las etimologías, campos de fuerzas semánticas, estructuras conceptuales o de contenidos convenientes.

A través de ello, por ejemplo, se puede analizar la proximidad, en términos de experiencia $-\mathrm{y}$ entonces, también poner en práctica real unos principios básicos para la introducción de acciones cognitivas como la del entendimiento de la vieja relación (de la cuestión) cerca lejos- del o de los elementos discursivos elegidos con respecto al sujeto que ejerce la relación o al actor que de algún modo produce la reflexión.

Por otro lado, también hace visible la arquitectura inicial o la estructura mínima de toda acción pedagógica, que nosotros denominamos modelo rutinario de acción pedagógica (o acciones pedagógicas destructivas), en la que por otro lado hemos detectado un problema sustancial relativo al 'incipit', que apunta a la cuestión del comienzo, a la cuestión de atender, de entender y de pensar el comienzo. Una estructura o arquitectura inicial que lejos de ser una virtud constituye una problemática cuya condición motora permanece desde los tiempos de los tiempos albergado en su fondo, incidiendo generalmente a la hora de estructurar o diseñar las nuevas estrategias u orientaciones cognitivas y el conjunto de las direcciones específicas para su acceso, cuya imagen la damos a través del símil teatral de una escena simple en la que, como sujetos hipotéticos de la acción, se perciben definidos dos actores encajados en un contexto.

Esto que en apariencia puede parecer normal esconde más de una cuestión relativa al conocimiento en términos cuantitativos y cualitativos (de una conciencia optimizada de aquello que como conocimientos se 
tiene, de aquello de lo que de su organización se puede dar fe, o de aquello de lo que el imaginario esta constituido y también de sus déficit), y el conjunto posible de modelos para su puesta en circulación o, por otra parte, su transmisión.

El problema que comporta es que como modelo trabaja sobre la base de una imagen, de una representación sin proceso (de algo de lo que, a su vez, es representación, de sí y para sí), y por lo mismo no contempla aquello que el propio símil insinúa, que no es mas que la acción. Como si de la negación de los procesos perceptivos y la desatención de los comienzos se tratara. Esta cuestión recuerda -pero sólo en el sentido del entendimiento de la figura que exponemos, y aunque en éste caso, más que una posición es, porque lo constituye, un déficit formativo de la estructura e imaginario obra de arte contemporánea de la que más adelante hablaremos-, a los iconoclastas conscientes del valor exacto atributivo a las imágenes y su necesaria exorcización de la muerte de referente divino, sobre los que cayó la acusación de negar y despreciar las imágenes, y a los iconólatras "ya que tras la fe en un Dios posado en el espejo de las imágenes, estaban representando la muerte de este Dios y su desaparición en la epifanía de sus representaciones"68; con la distancia necesaria como para entender que en nuestro caso todo apunta y marcha hacia las nociones bien de desconocimiento, bien de déficit, que usamos en sentido crítico, o sea, en el sentido de una advertencia ante una cierta e inconsciente desviación [y desatención], desde (y de) las cuestiones formativas (aquellas que conforman o hacen lugar a infinitas proliferaciones de sentido) hacia las contributivas, aquellas cuyo valor se clasifica según la cosa tal cual, como [aunque referido a imágenes que deberían constituir acciones que, a su vez, deberían constituir cosas] una empírica interpretación hermenéutica o, de algún modo, un cierto esencialismo o inmanencia (las cosas particulares necesariamente poseen esencias o naturalezas inmanentes en virtud de las cuales son lo que son) también empírico, en tanto se omite la reflexión sobre la imposibilidad de que algo pueda ser uno y lo mismo. Es importante, para tratar el concepto de imagen, conocer a los iconoclastas y a los

68 BAUdrillard, JeAn. Cultura y simulacro. Editorial Kairós, 1987. Pág 16 
iconólatras. Steiner relaciona esta vaciedad con las presuposiciones teológico-metafísicas, en el sentido de la conformación sintáctica de la noción de esperanza y en consecuencia, la omisión del tiempo de la acción y el espacio de la acción (porque sitúa), que referencia a ese algo esencial para que se produzca una emoción y en tal sentido para que tenga lugar una forma de conocimiento. En la admisión de la acción también se omite el paisaje, lo que quiere decir que no hay lugar para el conocimiento, que no hay lugar objetivo para la constatación de nada, y menos, para la (su) emisión.

En este punto, estamos en condiciones de configurar el modelo visual del comportamiento de esa primera acción de carácter pedagógico, de cómo se le entiende y, en todo caso, de cómo es posible activarla.

\subsubsection{Principio de verificación}

El Principio de verificación es una herramienta categorial que hemos heredado del pensamiento de Rudolf Carnap, cuya sustentación principalmente descansa en la tesis de que la filosofía es sobre todo análisis lógico del lenguaje ${ }^{69}$ y no otra cosa; la hemos heredado específicamente de su propuesta de método de análisis (basado en el desarrollo de la lógica moderna ${ }^{70}$ y las nuevas teorías del conocimiento) de las proposiciones metafísicas, entendidas entonces como expresiones no significativas y por tanto, no verificables desde el punto de vista empírico. Herramienta que si no usada como verificador de significaciones proposicionales en la sintaxis filosófica, a nosotros nos

69 CARNAP, RUDOLF. “La superación de la metafísica mediante el análisis lógico del lenguaje" en AYER, A., El positivismo lógico, FCE, Madrid 1986

70 "Las investigaciones de la lógica aplicada o de la teoría del conocimiento, cuyo propósito es esclarecer por medio del análisis lógico el contenido cognoscitivo de las proposiciones científicas y, a través de ello, el significado de las palabras que aparecen en dichas proposiciones, conducen a un resultado positivo y a uno negativo. El resultado positivo es elaborado en el campo de la ciencia empirica: se esclarecen los conceptos particulares de distintas ramas de la ciencia, se explicitan tanto sus conexiones lógico formales como epistemológicas." CARNAP, RUDOLF. "La superación de la metafísica mediante el análisis lógico del lenguaje", en AYER, A., El positivismo lógico. México D.F.: Fondo de Cultura Económica, 1986. Pág. 150. Publicado originalmente en el Volumen II. Revista Erkenntnis, 1932. 
sirve -en tanto que los problemas artísticos de igual modo que los filosóficos tienen un carácter también sintáctico- como verificador analítico de la naturaleza operacional de los elementos discursivos puestos en cuestión.

Ocurre que cada elemento discursivo, para ser significativo, debe poder ser verificable (como toda expresión cognitivamente significativa), a través de una observación o un conjunto de observaciones que permitan determinar la naturaleza de su operatividad. Es precisamente en la ocasionalidad y en la falta de clasificación formal del lenguaje de cara a la constitución de la idea de obra -y en consecuencia, en el conjunto de expresiones no significativas que, en ese específico tramo de la articulación proposicional de la idea, tiene lugar-, donde la verificación ejercida sobre los elementos discursivos inscribe su potencia de utilidad.

El hecho de que la filosofía sea en sí misma una herramienta de análisis lógico del lenguaje y de que las proposiciones artísticas sean, al igual que las filosóficas, cognitivamente significativas nos corrobora la correspondencia -por otro lado evidente- del carácter sintáctico que guardan los problemas de uno y otro ámbito. En tal sentido la importancia que para nosotros tiene el método de verificación de Carnap radica en el doble papel que juega en el ámbito de análisis del conocimiento: a decir, el papel de eliminar del campo y aplicación de la filosofía el problema de las expresiones no significativas, sobre todo de las proposiciones metafísicas, en tanto que la filosofía -en su rol de análisis lógico- "consiste en el análisis de todo conocimiento, de toda aseveración de la ciencia o de la vida cotidiana, a efecto de clarificar el sentido de tal aseveración y las conexiones entre ellas"71, por lo que la filosofía es para él, y sólo cobra sentido, como sintaxis lógica del lenguaje, y como nada más, partiendo de la naturaleza sintáctica de los problemas del conocimiento, de todo el ámbito del conocimiento general. Ahora bien, en relación al uso que dentro de nuestro sistema didáctico le damos a la herencia metodológica de Carnap, cobran una especial relevancia los

71 CARnap, Rudolf. Filosofía y sintaxis lógica. Ed. Universidad Nacional Autónoma de México, México, 1963. Pág. 7. 
dos tipos de verificación que su sistema ofrece: la verificación directa y la verificación indirecta, y también la Sintaxis Lógica, o sea, el método de ejercer el análisis.

El tipo de verificación directa abarca, y siempre se refiere al conjunto de enunciados perceptuales actuales, aquellos que refieren al momento presente de la percepción o relativos a ellos: "distingo el humo blanco en el valle". En este tipo de verificación la proposición es comprobada -como cognitivamente significativa- si en éste momento distingo tal cual el "humo blanco en el valle" y si no, entonces no es comprobada.

Por otro lado, el tipo de verificación indirecta trata o abarca aquellos enunciados $\mathrm{X}$ que no pueden ser verificados bajo el tipo directo pero que si pueden serlo de modo indirecto a partir de un enunciado deducido de $X$ que va a ser verificado y del que podemos deducir una predicción.

Tomemos uno de sus ejemplos: el enunciado "La puerta es verde" es $\mathrm{X}$ (que se puede comprobar), "De la mezcla de los colores amarillo y azul se obtiene el verde" es el enunciado $X_{1}$, entonces con el enunciado experimental X2 "Mezclemos los colores" obtendremos la predicción X 3 "las mezcla de colores se torna azul"; por lo tanto si $X_{3}$ se da o tiene lugar es porque entonces $X$ ha podido ser comprobado.

Es en referencia a la teoría formal específica de un lenguaje determinado, al estudio de su correcta formación (relación entre signos, relación entre secuencia de signos, prescindiendo del sujeto que habla, y del conjunto referencial al que apuntan de algún modo las oraciones) a lo que Rudolf Carnap llama sintaxis lógica de un lenguaje, desvinculado, puesto que para nada hace referencia a ello, de los sentidos oracionales y de los significados de las palabras, de lo que dice, "no se refiere al sentido de la oración o al significado de cada palabra". Ahora bien en éste punto puede llamar la atención algo que en apariencia se nos muestra como contradictorio según el uso que nosotros hemos intentado dar a las partes categoriales y metodológicas heredadas de Carnap; ello tiene que ver con la no referencia al sentido ocasional o al significado de cada una de las palabras en cuestión. Sin embargo, esta separación que de principio establece el método de análisis de Carnap, a nosotros bien que nos interesa en tanto que partimos de la idea de uso de dos morfologías de lenguaje sometida una a la otra, cuanto a las afectaciones propias de 
sus sintaxis: a decir, aquella que tiene que ver con la especificidad teórico y formal del modo de práctica (en este caso artística) y la que tiene que ver específicamente con el modo de hablar.

En ese sentido podríamos establecer un análisis desde la proposición orientada a la articulación de la idea de obra en más de una dirección: la propia perteneciente al lenguaje, la propia tocante a la teoría formal del modo de práctica, y como tal, verificar si las direcciones proposicionales [palabra por palabra] a las que apuntan los elementos discursivos elegidos, corresponden o no -si se abren sus potenciales de previsiones sintácticas, en términos gnoseológicos- con los contenidos cognoscitivos a los que se aspira, y en todo caso, dar por probada o no la especificidad de la naturaleza de obra que la idea [entonces idea de idea de proyecto de obra] sugiere. Ahora bien, de forma contraria al uso que Carnap da a su sintaxis lógica cuando dice de su funcionamiento "sino simplemente como serie de símbolos de signos escritos, hablados o de otro género", nosotros no hacemos ningún tipo de exclusión en cuanto a la verificación de significados que incluye la participación del sujeto.

Por ejemplo: El enunciado zi "Voy a esculpir la muerte" necesita ser comprobado en términos indirectos y por tanto con denominación de hipótesis, para ello tenemos que deducir un enunciado z2 "¿Soy escultor?", de modo que si la respuesta es "si", tendremos que verificar el segundo tramo (también de forma indirecta) con el enunciado de interrogación $\mathrm{z}_{3}$ "¿La muerte es un objeto?", al ser 'no' la respuesta podremos seguir formulando enunciados " $\mathrm{z}$ sucesivos", hasta llegar a una conclusión cuya sintaxis sea correcta y que aplica una comprobación válida en términos lógicos. En ese sentido el enunciado $\mathrm{z}_{4}$ "Soy escultor pero no puedo esculpir la muerte porque no es un objeto", sería el correcto, del que a su vez podemos extraer una primera conclusión operacional en forma de proposición z5: "la idea de esculpir la muerte no admite representación escultórica", de modo que dicha formulación a través de la acción de esculpir resulta -desde la teoría formal de lo que entendemos por escultórico, sintácticamente incorrecta por lo que teóricamente no encuentra sostén alguno. Sin embargo, tomando como punto de partida el hecho de que el enunciado zi "Voy a esculpir la muerte" ha requerido un método de verificación de modo 
indirecta -toda comprobación debe necesariamente encontrar el método óptimo de verificación de las aseveraciones proposicionales- podemos seguir verificando (también de modo indirecto) a partir de enunciados deducidos propiamente del enunciado $\mathrm{z} 1$ o de enunciados sucesivos deducidos del enunciado $\mathrm{z} 4$-por constituir ambos, sendas premisas ya de por sí verificadas-, como en los siguientes ejemplos: el enunciado Z5 "Soy escultor y tengo una definición de escultura", que al ser comprobado deducirá uno z6 del tipo interrogativo "Qué definición de escultura", que a su vez obtendrá la comprobación z7 "La escultura en el campo expandido", seguido de z8 "Los límites de la escultura no se reducen al objeto", de z9 "El hecho escultórico puede entenderse como un dispositivo procesual" y de z1o "Puedo aludir a la muerte a través de un hacer escultórico".

El sentido que en nuestra metodología cobra el principio de verificación de los enunciados proposicionales orientados hacia lo artístico y en ellos los elementos discursivos detectados, es de revelación de todo desajuste sintáctico -de naturaleza no-significativa y carente de perceptibilidad- pretendido como proposición gnoseológica (de ser valor y posibilidad de conocimiento) más allá de todo fundamento experiencial. A través de verificaciones simples detectaríamos el conjunto de palabras, elementos discursivos insertos en una proposición o cadena proposicional de forma errónea o aquellos significados deducible solamente mediante una cadena de verificaciones. El hecho coincidente del carácter sintáctico tanto de los problemas filosóficos como artísticos nos facilita de alguna manera, en éste último ámbito -pensado el problema como parte o elemento y no como el sistema artístico mismo-, detectar la posibilidad o no, de que una proposición artística sea verificable o no (que active su propio modo de verificación y operatividad); en cuanto a ello, sólo basta que sea conocido previamente el contexto circunstancial en el cual la proposición ha de resultar verdadera, y por tanto cognoscible.

Los enunciados orientados hacia los modos de hacer artísticos, como igualmente ocurre con los enunciados ligados o propios de la filosofía -ligados al campo del conocimiento-, son verificables en la medida en que es posible deducir de ellos predicciones acerca de observaciones 
operacionales futuras e incluso del reglaje de cómo en torno a ellas debería proceder el pensar, sobre todo en relación a las progresiones y los eventos propios de la subjetividad que, como sabemos, abarcan el pensamiento, las imágenes, los sentimientos y los afectos, en el radio propio de los modos de hacer artísticos. 


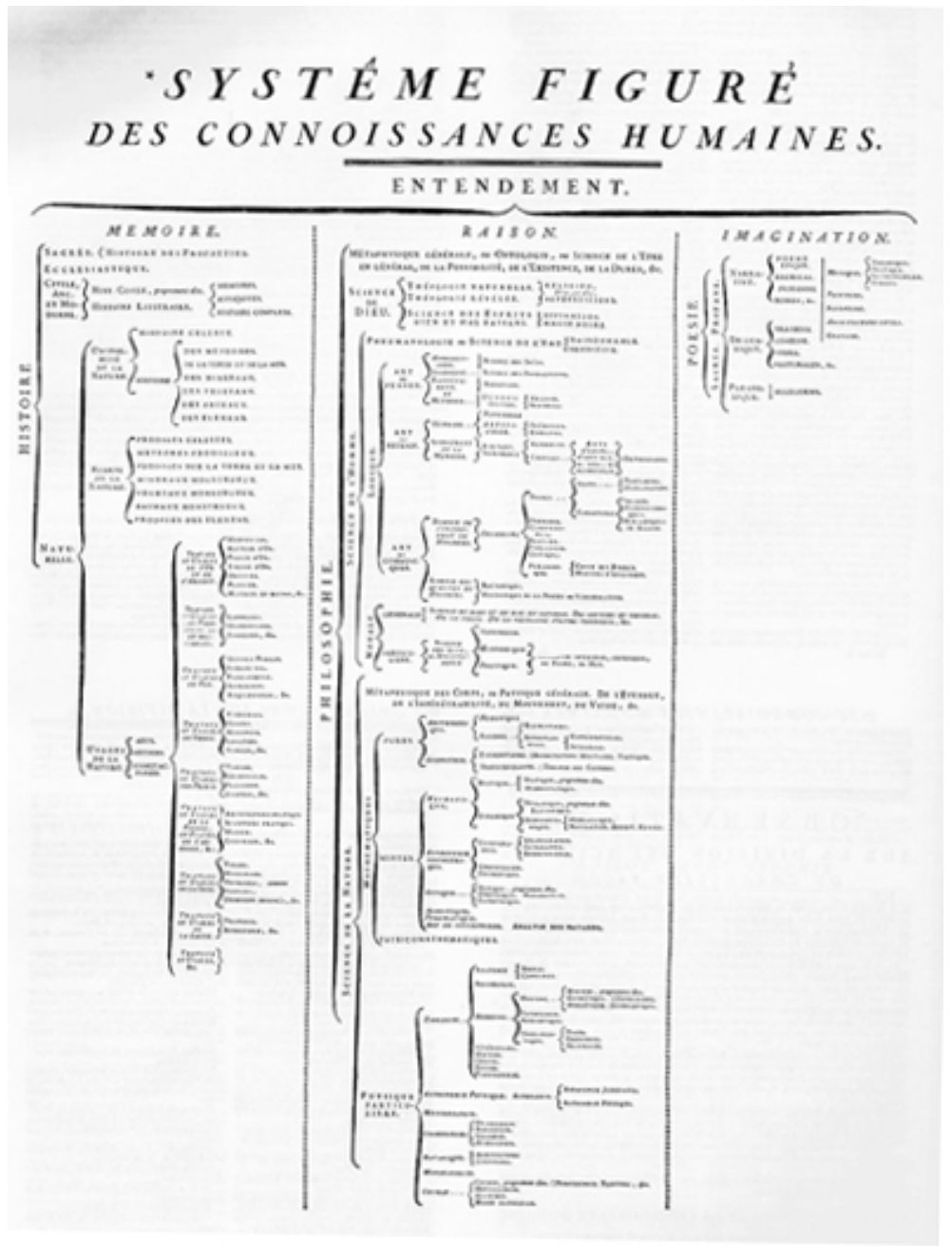

Figura 14: Mapa del conocimiento

"Todo conocimiento racional, sea enseñado, sea adquirido, deriva siempre de conocimientos anteriores", dice Aristóteles en los Segundos Analíticos dejando ver en su análisis una cierta, aunque no explícita, memoria o 
influencia del Menón platónico donde es señalada la diferencia entre un conocimiento cierto, que puede ser muy bello pero que nada vale, y el conocimiento por los fundamentos. Es de la especificidad de la estructura racional -en el sentido preciso expuesto en las primeras líneas de los Segundos Analíticos-, de lo que Aristóteles nos habla al buscar las características del conocimiento científico (conocimiento geométrico), por tanto cuando nos dicen que todo conocimiento racional deriva de conocimientos anteriores a lo que está haciendo referencia específica es a que ese conocimiento sobre todo deriva de las premisas o de los principios; esto como es evidente ocurre de igual modo en las ciencias y en el conjunto de las artes.

Aunque el principio de conocimiento que Aristóteles nos propone apunta estrictamente a la lógica y en menor medida a la epistemología y la psicología, para nuestro propósito estas dos últimas cobran mayor importancia en relación con la idea de conocimiento de Moritz Schlick, quien "Mantuvo que todo conocimiento genuino consiste en una reducción de una clase de identidades a otra o, lo que es equivalente: en la derivación de proposiciones más específicas a partir de otras más generales" ${ }^{72}$.

Éstos dos principios de conocimiento -el de Aristóteles y el de Schlick-, nos sirven de base para la argumentación de nuestra idea de principio base de articulación de las estrategias de conocimiento tanto para un estudiante de bellas artes como para un investigador o un espectador. $Y$ nos sirven en el sentido de que esos dos principios de conocimiento de partida $-y$ Aristóteles, cuando reflexiona sobre el conocimiento racional lo hace sobre todo acerca del conocimiento geométrico, por tanto discursivo- convienen a los procedimientos retóricos y, al mismo tiempo, a los dialécticos, consistentes como sabemos en la necesidad del nexo, de establecerlos como constatación de que es con respecto a la cosa desde donde entonces se la conoce, y porque incluyen la discusión [en el plano estratégico] sobre las diversas y múltiples alternativas operatorias.

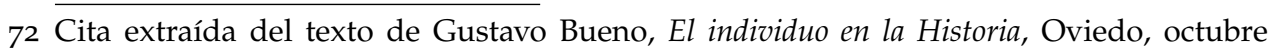
1980. Pág. 18. 
Es el sentido aristotélico del procedimiento dialéctico el que nos interesa, sobre todo, cuando dice: "Creemos conocer las cosas de manera absoluta y no por modo sofístico o accidental cuando conocemos la causa por la que existe la cosa y que ésta no puede haber sido de otro modo", porque supone el principio también [estatus gnoseológico en relación al modo de formulación de la idea de obra] de que no pueda llegar a pensarse que la cosa ocurra de otro modo en oposición al habitual planteamiento psicológico determinista de "tener que pensar de este modo" que prefigura como es evidente la perspectiva operatoria -el conjunto de operaciones que realizamos y que nos conducen al supuesto "lo que es" como absoluto o, como diría Gustavo Bueno, necesario o determinista.

Esto que llamamos Conocimiento de Principio nos permite armar un esquema base del cual partiríamos para el diseño de nuestra estrategia de acción reflexiva (y pedagógica), a cuyos parámetros los llamaremos "planos" (en el sentido de elemento ideal que nos sirve para identificar la localización de los parámetros a tratar interrogativamente) y para su posterior uso operatorio quedarían reducidos a sus siglas, de modo que el elemento identificador plano, quedará representado por una ' $p$ ' minúscula en cursivas y el resto, los elementos que nombran o activan la posibilidad de nombramiento, como por ejemplo Universo Arte o Mundo Arte, también quedarían reducidos a sus siglas, aunque esta vez, en mayúsculas, del tipo 'UA' o 'MA':

-Plano de los Conocimientos Anteriores (pCA):

-Plano de la Reducción de una clase de identidades a otras o Plano Derivación de proposiciones más específicas a partir de otras más generales: $\mathrm{pRCIO}$ o $\mathrm{pDP}+\mathrm{EPO}+\mathrm{G}$

-Carácter discursivo del conocimiento racional $>$ [conveniente a los] procedimientos retóricos y a los dialécticos $>$ necesidad del nexo.

Mediante la relación Conocimiento de Principio, conoceríamos el conjunto de conexiones causales, gracias a las cuáles nos pondremos frente a la verdadera necesidad (material, causal) de actuación -necesidad con proyección de significación gnoseológica-, para dirigir la estrategia propositiva argumental hacia zonas problemáticoesenciales (cumplimentación de las expectativas de constatación universales esenciales, en el sentido de la armazón sistemática de la 
autodemostración ${ }^{73}$ y nexos) y no meramente enumerativo-descriptivas (o sea, a dar satisfacción a las expectativas contemplativas u objetivas del sujeto, en nuestro caso un sujeto estudiante, investigador o espectador. "De este modo, [en el lugar del sujeto, dicho con palabras de Gustavo Bueno, aunque pronunciadas en el ámbito del principio del conocimiento científico, y que aún así, sería útil a nuestra propuesta], el regresus inductivo hacia lo universal, que está ya presidido por las conexiones necesarias de la realidad [revelada] en la sensación o, en general, en los conocimientos particulares...". Esto dicho al modo de Gustavo Bueno, propicia una grado de separación necesario entre los momentos esenciales de los procesos operacionales del sujeto (estudiante de bellas artes, investigador o espectador) que son (y para ello nos apropiamos de las nociones de momento material y momento formal) la actividad operacional propiamente dicha y la de disociación de simbologías.

\subsubsection{Reabrir la cuestión gnoseológica respecto a los procesos creativos}

El problema que plantea nuestro esfuerzo -y aquí nos enfrentaríamos con ese realismo del conocimiento generalmente confundido con el neoplatonismo, marcado por la creencia en la realidad del mundo exterior y en la objetividad fundamental de los sentidos que cada individuo puede darle- es hacer constatable que el desarrollo de una acción disciplinar, como podría ser una metodología del arte o de aproximación al proceso creativo, no se presenta como algo -al estilo de una clasificación de los conocimientos-, sin reabrir la discusión sobre la naturaleza misma del objeto considerado. Reabriría como necesario la cuestión gnoseológica respecto a los procesos creativos relativos a los modo de prácticas artísticas a la vez que desplazaría el anacronismo del horizonte de competitividad e innovación de los propios modos de prácticas.

Es precisamente innovación uno de los términos que habitualmente transita en el pensamiento de los artistas. La innovación subyace en la

73 "Porque la ciencia es demostración y la demostración sólo puede ser de lo necesario, que procede de principios verdaderos." BUeno, Gustavo. Íbidem. Pág. 22 
propia voluntad de hacer, sin embargo subyace como inconsciente, en un fondo repleto de presiones y inmediaciones provenientes casi siempre de un paisaje de implementaciones generalmente culturales, cuyo fondo es perversamente económico. La conciencia de innovar, como un acto del habla parece no suponer una mejora, desplazamiento o ampliación de los márgenes o límites funcionales de la cosa construida y estable si no más bien, un imperativo u ordenanza a la competitividad. Hoy por hoy la innovación, en su uso inespecífico, que es como habitualmente se la trata, es el resultado de la presión mediática. Resulta sorprendente constatar la creencia de que innovación es un término relativamente reciente, y más sorprendente es que no se le asocie con su significado literal, que es renovación, cuyo prefijo ${ }^{74}$ re marca el peso decisivo sobre la vuelta al si presencial de la cosa, a lo suyo propio, que estando ahí desde antes será o ha sido intervenido y mejorado. El haber sido de la cosa en la innovación es potencialmente más interesante que su porvenir, en tanto describe el glissando dialéctico y conectivo con el estado de cosa por ser, con ese, entonces, grado 'plus' de lo que será. Ese estado por ser sólo encuentra la posibilidad de transmutación del valor en el haber sido y ser presente de la cosa; es sólo ahí, en ese tramo, donde el cambio de situación de una cosa a otra y donde el agenciamiento del plus y nuevo valor, pasan a ser 'suyo propio' y por tanto particularidad. Es en ese sentido en el que el término innovación -y el conjunto de conceptos que manejamos en general-, ocupa o encuentra un lugar en nuestra didáctica. El sentido en el que se la analiza y se la instrumentaliza, de modo que es separada o extraída de un modelo de práctica retórica y tecnicista75, al que llamamos burbuja de competitividad o sistema de

74 Del latín præfixus participio de præfigére 'colocar delante'. Es un morfema de la clase de los afijos que se antepone a una raíz o base léxica para formar una forma lexical con diferente significado (prefijo derivativo) o que expresa categoría gramatical diferente (prefijo flexivo).

75 "El modelo tecnicista eficientista apunta a tecnificar la enseñanza sobre la base de esta racionalidad, con economía de esfuerzos y eficiencia en el proceso y los productos. El profesor es esencialmente un técnico: su labor consiste en bajar a la practica, de manera simplificada, el curriculum prescrito por expertos externos en torno a objetivos de conducta y medición de rendimientos. El docente no necesita dominar la lógica del conocimiento científico, sino las técnicas de transmisión, esta subordinado, no solo al científico de la disciplina, sino también al 
ansiedades progresivistas, cuya principal confusión reside en el hecho de haber entendido innovación y guía como el mismo supuesto: o sea, de una práctica que sigue al término, entendido como guía o imagen, asumiendo por tanto, también el desvarío, en su sentido literal, de darle caza a la innovación ${ }^{76}$.

Es en la cuestión necesaria de reabrir la discusión sobre el conocimiento de la naturaleza de la idea de idea de proyecto de obra, en aquello en lo que descansa nuestro esfuerzo. Esto es -en tanto que si no estaríamos desde el inicio mismo en un estado constante de perplejidad y confusión-, reabrir la necesaria discusión sobre el punto de vista (la escopia) que sobre el objeto el cuestión se tiene. En todo caso lo que caracteriza a una investigación es el enfoque o punto de vista. Aquí, (y estos ejemplos serán retomados posteriormente) a modo de ilustración, podría pensarse en dos ideas, por tanto dos puntos de visión, sobre un objeto concreto: la mesa; por un lado, la mesa de Camnitzer, según su enfoque de analfabetismo disciplinar, de la que su esencia generalmente se desconoce, y por el otro, la mesa de Regis Debray, en su libro Introducción a la mediología77, que admite múltiples principios de análisis, y por ello, el individuo que de algún modo la observa recibe varias cartas de identidad del objeto observado. La cuestión no consiste en multiplicar las vías sistemáticas de interpretación de cada tramo del problema, no se trata de interpretación sino más bien de hacer constatar la necesidad de construir una experiencia en la misma medida en que profundizamos nuestra familiarización con las cosas, ya sean obras, objetos, situaciones, nombramientos, lenguaje, contexto o paisaje. En ese sentido, el método de análisis de detección de los elementos

pedagogo y al psicólogo. ¿ Que decir del vasto arsenal de cursos proporcionados por la tecnología educativa basada en el neoconductismo skinneriano?. ¿Y de la formación inicial en instituciones terciarias no universitarias, con titulo de valor amenguado?. ¿Y de los cursos de capacitación o perfeccionamiento que no logran ser posgrados reconocidos? Se podría seguir enumerando mecanismos que consagran esta posición de docentes como técnicos, no como intelectuales." DE Lella, Cayetano. "Modelos y tendencias de la Formación Docente". Edición online: http://www.oei.es/cayetano.htm

76 Vease como contraposición el estudio realizado por YProductions, titulado Innovación en la cultura. Una aproximación crítica a la genealogía y usos del concepto.

77 DEBRAY, REgIs, Introducción a la mediología. Editorial Paidós, 2001 
discursivos podría constituir, como cualquier otra herramienta de análisis, un ángulo de posicionamiento del ver, un punto de vista también para la reflexión y elaboración de tramos específicos de los modos de hacer práctica artística. 


\subsection{LA DIDÁCTICA DE LOs elementos discursivos}

La didáctica de los elementos discursivos pretende ser una herramienta metodológica para la construcción, definición y análisis de la idea de idea de proyecto de obra. En principio, todavía no es una teoría consolidada pero en el futuro podría pretender serlo. No lo es porque no constituye un conjunto de opiniones generalizadas y sistemáticas sobre el particular segmento de la realidad que nuestra naciente didáctica atiende: la construcción, definición, análisis y reflexión de la idea de idea de proyecto de obra. ¿El corpus? Sí, el corpus quedaría limitado a la idea de obra artística y aquella que aspire a constituirse en ella. La dificultad en ese sentido la encontramos en los marcos que delimitan una idea de obra artística de una que no lo $\mathrm{es}^{78}$, por tanto, en la formulación de las características con las que conferir límites a ese inestable corpus. Lo más común es que se piense que siempre que por nuestra mente fluyen un sin fin de imágenes (unas veces de forma torrencial otras no tanto) estamos teniendo una idea o ya la hemos tenido, pero no es así. Aquí nos encontramos con el problema y la complejidad de la definición de partes: ¿Qué es una idea?, ¿Qué es una imagen?, ¿Qué es el acto de creación?79

En un primer intento podría ser algo así: en principio una idea no es una imagen, y en consecuencia una imagen no es una idea. Una idea empieza a tener lugar cuando se la acota, cuando se clarifica, para ella, un corpus particularizado y con ello su proyección potencialmente significativa -cuando se atiende en términos experienciales, la semántica progresiva o estable del comportamiento lenguaje de sus partes. Esto se refiere, de forma esquemática, a la detección de los realismos internos de los elementos fuentes; por lo mismo, cuando se da esa situación en que el elemento fuente se nos descubre como un valor de cognitividad: que nos sirve para que lo conozcamos, y entonces para que de él, ¿para qué

78 "Lo que me parece es que el arte puede ser malo, bueno o indiferente, pero, sea cual sea el adjetivo, debemos llamarlo arte, y el mal arte sigue siendo arte igual que un mal sentimiento sigue siendo un sentimiento." DUCHAMP, MARCEL. "El acto creativo". Ibídem.

79 Conferencia pronunciada por Gilles Deleuze en la cátedra de los martes de la fundación FEMIS en 1987. Edición online: http://tinyurl.com/mf78g57 [Fecha de Consulta: 9 de enero de 2013] 
en relación con él?, tengamos una experiencia, por un lado de conocer, y por otro, de saber.

Un segundo momento en la construcción de nuestra didáctica correspondería a la descripción de la forma en la que se constituyen los indicios ideas de obras plásticas o visuales, de modo que la descripción obtenida, necesariamente, haga visible el sistema de indicios ideas de obras, del que partiríamos para la detección del conjunto de los elementos discursivos que orientarían no sólo la construcción, definición, análisis y reflexión de la idea de obra, sino que notificarían nítidamente la naturaleza misma de la obra por ser. Los conceptos que generalmente incumben a esta metodología tienen siempre un carácter, en el sentido foucaultiano, conveniente. Su concreción depende en su totalidad del cuajado, marco genérico y contexto necesario para la constitución de la idea: esto es, de una necesidad de aproximación, de un contexto especificado para tal empeño y de una experiencia como posibilidad de contraste.

Esa concreción en su totalidad, de la que más arriba hablamos, debería ser el resultado de la puesta a punto del lenguaje. De hecho, el sistema de indicios ideas de obras plásticas o visuales, sólo puede hacerse visible mediante la descripción textual, al estilo de Mieke Bal en su libro Teoría de la narrativa: Una introducción a la narratología ${ }^{80}$, del conjunto de intereses y elementos puestos en juego para la constitución de una idea con posibilidades de llevarse a cabo mediante un particular, o potencial, modo de actuación. En tal sentido, la cadena ordenativa de la construcción crecería de la siguiente manera y orden: Encargo, descripción textual, análisis y detección de los elementos discursivos, constitución de la idea, proceso constructivo de la obra.

80 BAL, MIEKE. Teoría de la narrativa: Una introducción a la narratología. Ediciones Cátedra, 2001. Madrid *Sobre este tema desarrollaremos una extendida reflexión en el marco del desarrollo del trabajo, que intentara introducir o poner en circulación el problema de la ideación de los ejercicios de clase en relación a los contenidos y el lenguaje. 


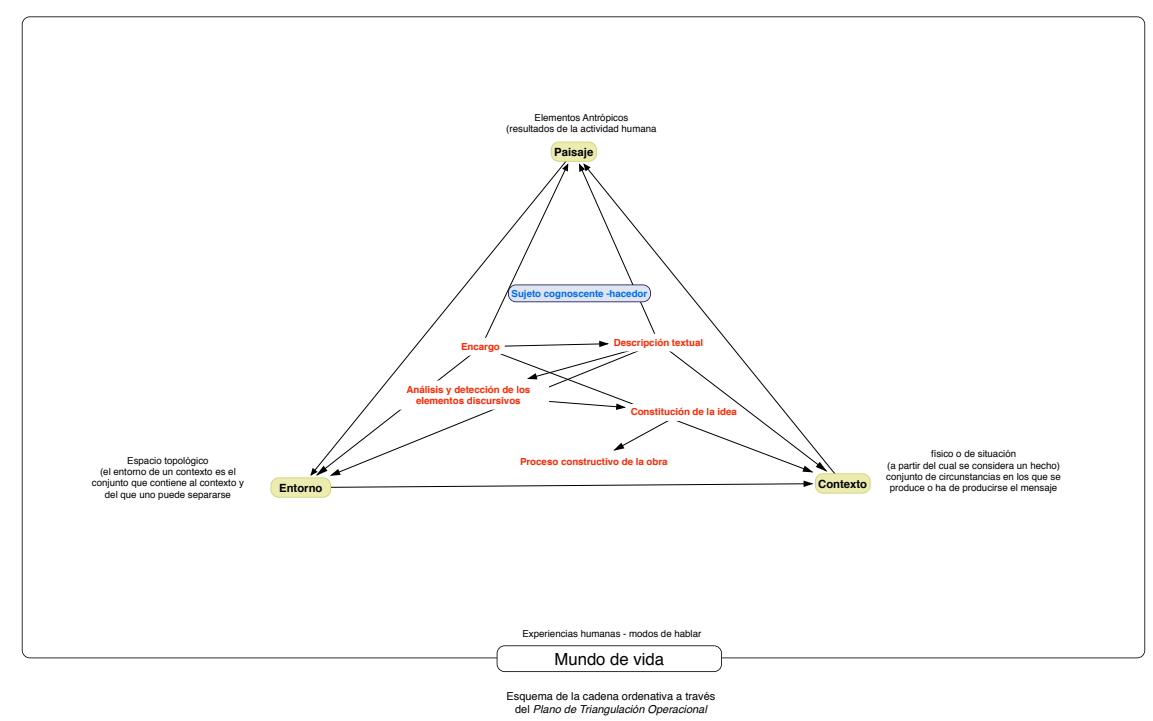

Figura 15: Esquema de cadena ordenativa a partir del Plano operacional

Ahora bien, volviendo a la cuestión de la concreción en su totalidad del conjunto de los elementos discursivos, y considerando que la descripción textual del conjunto de intereses y elementos para la constitución de la idea tiene su base en el lenguaje, hemos de considerar precisamente el lenguaje como el constructo inicial en la progresión constitutiva de la idea plástica, presuponiendo igualmente que la consideración, acentuada de la misma manera que no reflexionada, de la constitución progresiva de la idea a partir de la visualización de su imagen, no es solamente discutible, sino que es peligrosamente falsa.

Así pues las ordenaciones sucesivas, su esquematización o diagramatización ${ }^{81}$, corresponden a particulares esfuerzos y no a generalidades.

"El diagrama, terminología tomada de la filosofía kantiana, será el modelo abierto que cada artista-creador erige como paradigma a

81 Deleuze, G. - guATtari, F., Mil mesetas. Capitalismo y esquizofrenia. Ed. Pre-Textos, Valencia 2004. Pág. 144 
alcanzar. Pero debe comprenderse cómo este modelo no es para nada actual o cerrado, y no es susceptible de copia según el esquema representativo. El diagrama es, en este sentido, el sentido mismo del rizoma en tanto que condición de posibilidad de la creación de lo nuevo y que no tiene por qué tener relación de semejanza alguna con lo creado. El diagrama es entonces un signo-movimiento en tanto que lleva de lo virtual a lo actual de una forma semiótica no necesariamente lingüística." ${ }^{82}$

\subsubsection{La cadena $M d-c R-C e$}

En el tramo metodológico inicial, para que permita al practicante, hacedor o lo que sea, fundar los anclajes mínimos de un pensamiento agumentativamente coherente y dotado de objetividad desde el inicio mismo del análisis, nuestra didáctica ofrece -a modo de instrumental ordenativo básico o paso de pasos para el articulado estratégico básico-, lo que llamamos "la cadena Md-cR-Ce", cuya armazón guarda un cierto parecido con un algoritmo en el sentido de ser un conjunto de operaciones sistemáticas que nos permiten hacer un cálculo [tal vez diagnosticar, tal vez diagramatizar] una solución estratégica de aproximación a un tipo de problema, y que describe los grados de conocimiento del practicante en relación a los tres horizontes prácticos que la cadena describe y que como tal la constituyen, y por tanto, la potencia real de articulación de un cierto modelo de escrituralidad crítica (modelo expresivo, en el sentido en el que Derrida ${ }^{83}$ se refiere a la escritura, el de construcción-inscripción de la biografía y de la identidad, en su potencia de discernir en el propio trazado de la relación prácticaidentidad-biografía).

Los tres horizontes constitutivos de la cadena Md-cR-Ce, en conjunto de carácter ordenativo, tienen su base operacional y potencia de

82 LEÓN CASERo, JORge, Gilles Deleuze, en Fernández Labastida, Francisco - Mercado, Juan Andrés (editores), Philosophica: Enciclopedia filosófica on line, URL: http://www.philosophica.info/archivo/2012/voces/deleuze/Deleuze.html [Fecha de consulta: 12 de diciembre de 2012]

83 D'ailleurs Derrida un film de Safaa Fathy. 
efectividad en el reconocimiento de la necesidad de ordenación de la experiencia. Dichos elementos u horizontes de la cadena Md-cR-Ce lo conforman el modelo disciplinar, los conectores de relación, y el entorno o contexto. Estos tres elementos u horizontes de la cadena Md-cRCe actúan en el mismo orden y progresión del nombramiento de sus partes, o sea: Modelo disciplinar > conectores interrelación $>$ entorno o contexto.

Modelo disciplinar -El modelo disciplinar constituye el conjunto de todo aquello, que desde el punto de vista técnico se cree potenciador de aspectos formales y estéticos afines. El modelo disciplinar concierne en tanto que es un ámbito de cosas.

Conectores de relación -Los conductores de relación son las entidades lenguaje [en relación a, relacionado con, en conexión o conectado, adscrito a, etc.] que nos permiten las adecuaciones pertinentes o buenas acciones tolerantes, hacia o desde el entorno o contexto de acogida del modo disciplinar.

Entorno o contexto -El entorno o contexto, en la cadena discursiva, generalmente [esto forma parte de una creencia] es entendido como lugar de acogida del modo disciplinar, que en el fondo lo es, aunque su función es mucho más determinante que la acogida sin más, que la ve simple, básica, para albergar la dinámica de los modos disciplinares. En este sentido el contexto o entorno es el activador del conjunto de potencias de todo aquello puesto en relación con él. Esto es, que dota de contenidos convenientes, y propios, además de convenientias fuertes, al conjunto y dinámica del modo disciplinar, y por tanto le transfiere [del suyo propio, del imaginario que en el contexto se da] la narrativa necesaria que en todo caso le permite contarse a sí en su nuevo estado relacional. 


\subsubsection{De los Elementos discursivos: clave metodológica}

\section{"Los argumentos epistemológicos en arte y filosofía revelan una verdad 'neutral' y objetiva contraria a la falsedad" 84}

A este primer axioma de la modernidad cultural (marco de una modernidad estética) que da lugar a la elaboración y caracterización de una filosofía del análisis social, formal y cuasicientífico del arte, de manera general e histórica -en el ámbito de la pedagogía de la enseñanza de las Bellas Artes y propiamente de la didáctica de la obra plástica- no le hemos prestado suficiente atención, siendo precisamente en esa base axiomática donde se funda un pensamiento -un inicial pensamiento- en torno a las preocupaciones formales y expresivas de la comunidad del arte. Un pensamiento, desde el inicio mismo, vertebrado en dos grandes caracterizaciones del arte: el arte objetivo y el subjetivo. El primero, el arte objetivo, es concebido en los términos de una ciencia formalista, el segundo, el arte subjetivo, como "... de acuerdo con la caracterización de la psicología de un artista infantil, mitológico, genérico y libremente expresivo." 85 Pues bien, es precisamente como crítica a este primer axioma que toma cuerpo esto que llamamos, y que venimos ya explicando, didáctica o metodología de los elementos discursivos, y que durante años nos ha servido tanto como cuerpo teórico y práctico a la producción de nuestras obras, como también para nuestro desarrollo en la actividad crítica, pero esencialmente en la actividad pedagógica, cuya vocación transcurre orientada -ya desde la puesta en marcha del "Proyecto Nada"-hacia cuestiones relativas al origen (el incipit), la naturaleza, el alcance y la articulación cognitiva de la mismidad de la obra. En todo caso es la obra, su mismidad y entresijos lo que arrastra nuestra voluntad hacia una aproximación metodológica de aquello que parece constituir su formación inicial: el, o su, incipit operacional. La enseñanza de las artes visuales debería poner su acento, prestar mas atención pedagógica, al

84 D. EFLAND, ARTHUR/ FREEDMAN, KERRY/ STUHR, PATRICIA. La educación en el arte posmoderno. Ed. Paidós. Col. Arte y Educación. 2003. Barcelona-Buenos Aires-México. Capítulo: "El auge de la epistemología moderna". Pág. 40.

85 D. Efland, Arthur/ Freedman, Kerry/ Stuhr, Patricia. Ibídem. 
arte en sí y a su visualidad, a su complejidad y naturaleza, y del mismo modo hacerlo con la obra y con todo aquello que la caracteriza y abarca. Pero ¿es qué acaso la enseñanza de las artes visuales no pone su acento estratégico-pedágógico en el arte mismo, en la obra? sería la pregunta que, en todo caso, tendría un lógico lugar. Sin embargo, a pesar de ese cierto carácter lógico devenido de la contundencia de la enunciación, y tratándose de una cuestión en sí problemática como la enseñanza de las artes visuales, la pregunta sería entonces una pregunta incompleta en tanto que anticipa el acuerdo de la garantía -por ahí se dice quemarse las manos a favor- de la estabilidad si no de esos acentos estratégicopedágógico, por lo menos de la estabilidad de la enseñanza de las artes visuales, diríamos que, en general. Quiere esto decir que en la anticipación se omite la evidencia de tal desatención.

"La técnica del disfraz ha de favorecer una especie de visión selectiva: los filtros se disponen sobre los procesos cognitivos a fin de tamizar significaciones." 86

Del arte y de las obras de arte hablamos en un sentido generalmente representacional, lo hacemos en forma de representación de las frecuencias evocativas de las cosas-obras: describimos su aspecto y no transitamos su adentro. Posiblemente, a eso que entendemos por la obra de arte se le ha garantizado -y esto sería claramente uno de los tantos signos de la desatención del conjunto "de esos acentos estratégicospedágógicos" que al principio hemos señalado- no sólo un trato, sino un estatus de autovalidación similar al objeto de la naturaleza como las piedras, las nubes y las hojas a los que no se les pide que se refieran, signifiquen o justifiquen a sí mismas en términos externos. Es posible, como intuye T. McEvilley en sus reflexiones en torno a la tradición crítica formalista del período de posguerra, que a la obra no se le haya dejado nada excepto su presencia sensible, sin conceptos ni significación, ni relación con nada exterior a sí misma; sin embargo, a ello queremos añadir que esa aridez inducida, esa desecación tendenciosa, no ha tenido lugar únicamente en el tratamiento crítico que la crítica formalista

86 McEvilley, T., "Las cabezas son la forma, las cosas no son el contenido", publicado en De la ruptura al «cul de sac». Ed. Akal/Arte contemporáneo, 2007. Madrid. 
ha dado a ello sino también, tal vez como una consecuencia, en el tratamiento instructivo de la misma, en esa didáctica necesaria que permite su aprensión útil de cara a la enseñanza.

Hablamos, por tanto, de una didáctica en torno a la obra, de un pensamiento que permita dar mención -bajo el supuesto de una consciencia de la experiencia confeccional de la obra, de lo que sea que se expresa y, por lo tanto, de la devolución a la procesualidad de la obra, en el plano teórico, de la telaraña de su condicionalidad- de la explicación ordenada de las radiaciones que la constituyen y encantan. Todo esfuerzo por la consolidación de una didáctica de las artes visuales debería concentrar su atención en todo aquello concerniente, y que se da, en la experiencia de visualidad ${ }^{87}$, pero también, en las relaciones y flujos de conexión que tienen lugar con los otros órdenes de la experiencia. De ser así, la idea de la semántica del fragmento, de Benjamin ${ }^{88}$, podría constituirse como base.

La lista de elementos que por ahora disponemos deberían apreciarse como una serie de visiones parciales y reticulares de la enorme y compleja configuración que constituye la propuesta obra. Su vocación apunta hacia una didáctica básica por lo que su esquematización transitoria es extremadamente simple. De tal modo que en una cadena categorial básica, como lo es por ejemplo el Plano de triangulación operacional a partir del cual se dota de objetividad todo el proceso cognitivo en torno al problema de la constitución de idea de idea de proyecto de obra (a base de ordenaciones lógicas, se consigue distinguir $\mathrm{y}$ nombrar el origen semántico del elemento discursivo primario $\mathrm{y}$

87 Según menciona José Luis Brea:“el arte trabaja con ideas plasmadas en un orden de visualidad".

88 Como argumentan César Rendueles y Ana Useros: "Benjamin articuló su crítica del sujeto moderno a través de una semántica del fragmento. La yuxtaposición dialéctica de elementos autónomos -imágenes, textos, evocaciones, recuerdos...- genera una constelación de sentido: una retícula de conexiones significativas entre elementos independientes y distantes. El propio Benjamin definió este proceso cognoscitivo como una iluminación profana, distinta tanto de la ebriedad lisérgica como de la mistificación religiosa." Capítulo I "Iluminación profana. Una teoría del conocimiento," publicado en Walter Benjamin. Constelaciones. Instrucciones de uso. Ed. Círculo de Bellas Artes, Madrid, 2010, pág. 17 
aquellos correspondientes a la cadena sucesiva de elementos discursivos secundarios).

En todo caso la detección de un elemento discursivo, en el proceso de ideación de la obra, de la construcción de la idea, garantiza si no el porvenir estable de la idea al menos la naturaleza y dirección de la obra, garantiza el papel central en la definición de género y de obra. La detección de los elementos discursivos (su detección semiótica) produce un medio de localizar o definir el presente, $y$, en ese mismo sentido, a uno mismo en la relación constructiva de la idea-obra, detectamos, como algo listo para sobre ellos proyectar un nuevo valor, los repliegues y definiciones del extendido banco de imágenes, resonancias y flujos direccionales escondidos en ellos.

¿Un supuesto? ¿En virtud de qué construimos una obra de arte? Toda obra de arte es una forma cultural determinante, porque es el resultado de una construcción memorable - de una invención, habría sugerido Deleuze-, productora de criticidad. "La obra" es un devenir necesariamente integrado en algún modelo de discurso igualmente inventado. La vida contemporánea entraña una pugna (más que interesante fundamental), sobre la naturaleza, propiamente, de los contenidos de la obra, de la obra arte contemporáneo, pero sobre todo, en relación a su integración.

¿Un primer supuesto? La forma es, en su naturaleza profunda, el resultado de una configuración: Así, el contenido no habría de entenderse como un aspecto de la forma o limitado por ésta, sino como una parte o elemento de la configuración circulante que la consolida o, ya en el espacio de la reflexividad, de la forma. En tal sentido a la ordenación o eslabonado de la cadena transmisora de la cuestión "forma" tendríamos que añadirle una figura más (un eslabón) que, por lo tanto, sí completaría la configuración última -la forma.

¿Un segundo supuesto? En el contexto de la ideación de la obra deberíamos prestar más atención -también el artista en la consecuente progresión constitutiva de la idea- a las ordenaciones proposicionales, a los suplementos verbales y al juego de lenguaje oportuno. Tal vez, Marcel Duchamp, pensando en esa crucial importancia, proclamó aquello de que "lo más importante en la pintura es el título", pero claro, 
refiriéndose en toda su amplitud a la obra de arte en general, aunque también irónicamente -y entiéndase esto como un supuesto indirectoal carácter sospechoso de la propia práctica formalista que sostenía la tesis de que los elementos o indicadores verbales no eran para nada relevantes en la constitución no sólo de la obra, sino también de su ideación condicionada. En todo caso, Duchamp parecía más bien querer introducir en la discusión la cuestión de los otros ordenes de la experiencia como valedores también en la cadena constitutiva de la obra, y en su caso, de los contenidos, tal vez en un intento de echar por tierra la ya instaurada idea de la obra como una producción válida en sus propios términos: y en consecuencia separada y sin relación con nada, similar a la idea de creación de Dios.

\subsubsection{Los elementos discursivos son enunciados operacionales}

1- Los enunciados observacionales: este es un concepto extraído de las teorías del Empirismo y alude al tratamiento de las entidades observables -hechos o conceptos- disponibles a la percepción de los sentidos, incluso las abstracciones inestable (pertenecientes al ámbito de la Ilusión). Este elemento cumplen la función de enunciación de relaciones entre cosas. Favoreciendo una cierta consciencia de la relación enunciada (una expresión breve de lo subyacente o el conjunto de sus datos) y, por lo tanto, y en alguna medida, un conocer o saber -con posibilidades de operatividad- de la cuestión en sí. Ejemplo: enunciados

(la expresión breve de lo subyacente) del concepto "Silla" sería: su función = servir para sentarse. (la expresión breve de lo subyacente) del concepto "Silla" sería: su complejidad = un objeto complejo, un sistema. (la expresión breve de lo subyacente) del concepto "Silla" sería: su composición material = mixta. (la expresión breve de lo subyacente) del concepto "Silla" sería: varios materiales = hierro, madera, aluminio, pintura.

El conjunto de los enunciados señalados se proyectan, transcurren, como potenciales contenidos: de hecho son contenidos en sí-Direcciones semánticas naturales del ámbito obra- de la posible obra. De hecho la 
cadena sucesiva de enunciados observacionales puede ser infinita y cada unidad (en su infinitud), de ser seleccionada sería en sí la garantía de la naturalezas posible de la obra.

2- Los disciplinares básicos: estos elementos aluden al conjunto de los procesos disciplinares básicos y, por lo mismo, a acciones o procesos representacionales. Ejemplo:

- disciplinar básico (escultura) "esculpir" denota un proceso básicamente representacional $=$ representar la cosa bien real o bien imaginada mediante la escultura.

- disciplinar básico (pintura) "pintar" denota un proceso básicamente representacional $=$ representar la cosa bien real o bien imaginada mediante la pintura.

- disciplinar básico (fotografía) "fotografiar" denota un proceso básicamente representacional $=$ representar la cosa bien real o bien imaginada mediante la fotografía.

- disciplinar básico (litografía) “litografiar" denota un proceso básicamente representacional $=$ representar la cosa bien real o bien imaginada mediante la litografía.

- disciplinar básico (dibujo) "dibujar" denota un proceso básicamente representacional $=$ representar la cosa bien real o bien imaginada mediante el dibujo.

Ahora bien, estos elementos generalmente no aluden, casi nunca, o anticipan ser el resultado de una reflexión sobre sí (su naturaleza en conexión con el arte) en tanto son devenires representacionales de preocupaciones formales y expresivas.

3- Los contenidos latentes: ordenación McEvilley -del pensamiento quimérico. Fueron los críticos formalista del período de la postguerra -con sus sistemas de creencias apasionadas y a pesar de que estas devinieron en una ideología represiva-, los que abrieron la obra de arte a intensos y profundos análisis fenomenológicos, aunque, eso si, 
concentrados en la superficie puesto que los límites de su propio sistema de creencias no les permitía ningún auténtico tratamiento teórico concerniente, por ejemplo, a los múltiples niveles de irradiación del significado en la propia obra de arte.

La irradiación de los significados en la obra de arte siempre se da en múltiples niveles: desde el momento mismo de la ideación estratégica de la pieza hasta su anclaje en el espacio de circulación reflexiva del discurso. La cuestión de si el significado es inherente o proyectado -en sus múltiples niveles- desde fuera de la obra está tan abierta como la cuestión de si la belleza o el valor estético son inherentes o proyectados; sin embargo, abierta o no la cuestión del significado, esta válida la explicación de la experiencia artística -entonces en contra, pues por ahí todavía pululan los ecos de la forma en el arte como un absoluto- en tanto garantiza la no exclusión de la discusión de los elementos exteriores a la obra física: lo mismo los elementos de resonancia conceptual que los elementos de resonancia estética.

El conjunto de los elementos que aquí agrupamos cumplen real función en la obra como hecho acabado pero su progresión y cuajado es latente desde el inicio mismo de la ideación de la obra, desde el momento cero de la invención de las más mínimas relaciones. Todos ellos han sido extraídos del magnífico y riguroso ensayo de Thomas McEvilley, "Sobre la manera de disponer nubes", publicado en De la ruptura al "cul de sac» ${ }^{89}$, en el que analiza la relación forma/contenido desde su inicial condición de cuestión filosófica candente hace dos mil quinientos años, hasta las clarificaciones significativas en varios frentes: desde Walter Benjamin, Althusser, Harold Rosenberg o Nicolas Calas hasta Erwin Panofsky, Nelson Goodman y Thimothy Binkey. Partiendo de la ordenación inicial de McEvilley, nos hemos impuesto única y exclusivamente sintetizarlos y disponerlos como otros elementos más en la configuración del esquema didáctico en el que estamos empeñados.

I- Contenido que deriva del aspecto de la obra de arte que se entiende como representacional.

89 McEvilley, T., Ibídem, pág. 105. 
"Tendemos a sentir que la representación funciona mediante un elemento reconocible de semejanza objetiva, pero parece más exacto decir que lo que experimentamos como representación es, como el gusto estético, una respuesta culturalmente condicionada como hábito que no implica la semejanza objetiva. De hecho, es difícil si no imposible decir qué constituiría la semejanza objetiva. Y, a la inversa, la convicción de la semejanza objetiva habitual en nuestra tradición pictórica parece ejercer un control sobre nuestra percepción de la naturaleza. La tradición pictórica, presentada como representación de la naturaleza, ha rehecho nuestra percepción de la naturaleza para que se conforme con las convenciones de los cuadros. La semejanza que parece que vemos entre los cuadros y la naturaleza no resulta del hecho de que el arte imita a la naturaleza, sino del hecho de que nuestra percepción de la naturaleza imita a nuestra percepción del arte. La representación bidimensional, no es una imitación objetiva, sino un sistema de simbólico convencional que varia de una cultura a otra... Virtualmente toda cultura tiene una tradición de representación que considera sinceramente basada en la semejanza. Frente a un cuadro de la Batalla de Waterloo, parecemos reconocer caballos, armas, soldados, etcétera; sin embargo, lo que en realidad estamos reconociendo son nuestras maneras convencionales de representar caballos, armas, soldados, etcétera." $" 90$

\section{2- Contenido derivado de los suplementos verbales aportados por el artista.}

"En referencia a un cuadro de caballos, armas y soldados, por ejemplo, el título "La Batalla de Waterloo" inyecta un contenido específico que deriva no de los rasgos ópticos, sino de palabras."91

\section{3- Contenido derivado del género o medio de la obra de arte.}

"Este tipo de contenido cambia según cambian las fuerzas culturales ambientales. En los años 1960, en los Estados Unidos

90 Ibídem, pág. 109.

91 Ibídem, pág. 109. 
por ejemplo se produjo una dicotomía en cuanto al contenido entre la pintura y la escultura. La pintura pasó a implicar una falta de implicación directa en la experiencia, una absorción en preocupaciones indirectas, distanciadas. La escultura, por otro lado, se entendió, incluso cuando era representacional, como una presencia real de la objetualidad, pues ocupaba el mismo espacio que ocupaba el espectador, el espacio de la vida encarnada. De esta dicotomía ética derivó gran parte de la dinámica del arte de los sesenta y setenta. Los radicales nuevos géneros se asociaban con la escultura, a la performance se la llamaba "esculturas vivas", a las instalaciones "esculturas ambiental", etcétera. La pintura se asoció con los viejos valores de la convención, más que con la realidad. Que un artista escogiera trabajar con óleos sobre lienzo se veía como una declaración politica reaccionaria... "92

4- Contenido derivado del material del que está hecho la obra de arte.

"Dentro de la categoría de la escultura en los años 1960 y 1970, un artista que trabajara el mármol de manera representacional estaba en un nivel que hacía una declaración opuesta a la del artista que trabajaba con vigas en I o fuego. Los materiales artísticos tradicionales, los materiales industriales esotéricos materiales de alta tecnología, los más absurdos materiales (como el chocolate de Ed Ruscha), materiales neoprimitivos (como los huesos y la sangre de Eric Orr), materiales panteístas (como el fuego, etcétera, de Klein), engañosos materiales que se engañaban a sí mismos (plástico que parece yeso, madera preparada para que parezca piedra): todas estas decisiones del artista comportan un contenido tanto como una forma. Pronuncian juicios que el espectador de arte capta automáticamente sin necesariamente pensar siquiera en ellos como contenidos." 93

\section{5- Contenido derivado de la escala de la obra de arte.}

92 Ibídem, pág. 110.

93 Ibídem, pág. 110. 
"Evidentemente, las decisiones de escala tienen una significación formal; sus significados con respecto al contenido deberían ser igualmente evidentes". 94

De igual manera la opción de la escala puede ser una opcióncontenido al mismo tiempo que una opción-significado: ello como naturaleza estructural de la obra.

\section{6- Contenido derivado de la duración de la obra de arte.}

"La concepción platónica que subyace a la tradición de las obras maestras la formuló el poeta romano Séneca: "Vita brevis est, ars longa": la vida es corta, el arte duradero. Es decir la obra de arte se esperaba que sobreviviera al artista. La realidad temporal que la obra de arte vivía no era precisamente el tiempo histórico: su dimensión temporal propia era una posteridad concebida como una mezcla de tiempo histórico y eternidad. Con ella algo del alma del artista (su huella al menos) se haría también inmortal. El gran arte, en otras palabras, se consideraba que había capturado algo de la deidad. (...) Con la misma claridad, una metafísica opuesta afirman obras hechas en modos o materiales deliberadamente efimeros: una metafísica que afirma el flujo, el progreso y el sentido cambiante de la yoidad. La obsesiva expectativa de la posteridad está vinculada a la creencia en el alma y constituye, en efecto, una afirmación de que uno tiene un alma. Las obras que afirman el flujo implican el supuesto opuesto, que el yo es una situación transitoria que deriva de la telaraña de condiciones y está sujeta a los cambios de ésta". ${ }^{95}$

\section{7- Contenido derivado del contexto de la obra de arte.}

"El arte declaradamente específico de un sitio implica la selección del contexto como una declaración fundamental acerca del contenido. ¿Está protegida la obra apartada en un distante recinto vallado del desierto de Nuevo México? ¿O se la abandona en una sección u otra de un centro urbano? Los aspectos referentes al

94 Ibídem, pág. 111.

95 Ibídem, pág. 111-112. 
contenido en tales decisiones son tan importantes como sus aspectos formales." 96

\section{8- Contenido derivado de la relación de la obra con la historia del arte.}

"El modo más común de contenido derivado de su relación con la historia del arte está en el empleo de alusiones y citas para afirmar una relación especial con alguna otra obra o tradición de la obra. Recientemente el tipo más corriente de alusión ha sido a obras anteriores en la propia tradición de uno."97

9- Contenido que se va acumulando en la obra a medida que revela progresivamente su destino mediante la persistencia del tiempo.

"Ocurra lo que ocurra con la obra según su historia se desarrolle se convierte en parte de la experiencia de la obra, y en parte de su significado. Duchamp añadió contenido a la Gioconda. Tony Shafrazi al Guernica, y no se quien a la Pietà de Miguel Ángel en San Pedro. El hecho de que Greenberg utilizara las obras de Pollock como pruebas de la idea de la pintura sin contenido forma ahora parte del contenido de esos cuadros." 98

10- Contenido derivado de la participación en una tradición iconográfica específica.

"La iconografía es un modo convencional de representar sin el supuesto de que esté implicada la semejanza natural. De manera que para los cristianos el azul puede sentirse como el color de María sin ninguna sugerencia de que se parezca a María".99

11- Contenido derivado directamente de las propiedades formales de la obra.

"Así, todo lo vemos dentro de un marco de significado. Si de verdad las percepciones no tuviesen ningún contenido en absoluto, serían

96 Ibídem, pág. 112.

97 Ibídem, pág. 112.

98 Ibídem, pág. 113.

99 Ibídem, pág. 113. 
momentos en blanco en la consciencia y no dejarían ninguna huella en la memoria". ${ }^{100}$

12- Contenido derivado de gestos actitudinales (chistes, la ironía, parodia, etcétera).

"Este nivel de contenido suele implicar un juicio sobre las intenciones del artista. El deseo de persuadir es una forma de intencionalidad que satura algunas obras de arte. En la ironía, el ingenio, etcétera, el artista presenta algún nivel de contenido con indicaciones de que su actitud hacia él no es directa y aseverativa, sino indirecta y perversa. El proceso es complejo. La mente compara la afirmación recibida con otra afirmación hipotética que la mente construye como representante de la versión normal o directa y por contraste con la cual el enfoque anormal e indirecto puede percibirse y medirse. De manera que la indirección irónica, que entra en otra categoría del contenido, crítica ese contenido al tiempo que lo afirma, y altera la carga de significado."101

13- Contenido enraizado en respuestas biológicas, psicológicas, o en la consciencia cognitiva de ellas.

"Este es el nivel de contenido que se suele denunciar como "sensacionalismo" -sexo y violencia- con la denuncia supuestamente basada en un sentido de lo fácil que es construir imágenes que produzcan tales respuestas." 102

\subsubsection{Primeros elementos discursivos.}

Un elemento discursivo es una unidad de conocimiento. Un elemento discursivo verdadero es aquel que en su detección recupera, proyectualmente, la zona-tensión del recorrido significante del constructo de la idea de obra -aquel que descubre el grado fértil de resistencia de

100 Ibídem, pág. 113.

101 Ibídem, pág. 115.

102 Ibídem, pág. 115. 
la cosa a su captura y que evidencia el recorrido del mismo en cuanto término. El elemento discursivo nombra la naturaleza y verdad de la cosa en juego, y su análisis posibilita el encuentro extendido con esa naturaleza y verdad.

Ahora bien, ¿desde qué lugar un elemento discursivo nombra la naturaleza y verdad del constructo de la idea de idea de proyecto de obra?

¿Dónde y cómo localizar los primeros elementos discursivos?

Su localización: El principio de la localización de los primeros elementos discursivos tiene asiento, doblemente, en el lenguaje a la vez que en la mirada: el lenguaje es conveniente a la semántica, el fragmento a la mirada. De la erótica, avidez y el entrecruzamiento recíproco del uno en el otro es de lo que deviene necesariamente el encuentro, de lo que deviene en una zona de encuentro significativa y elemental a la que de inmediato se la nombra -se la personaliza como escrituralidad. Quiere esto decir, por lo tanto, que en la localización de un elemento discursivo va de igual manera un principio de escrituralidad, de comunión entre la biografía y la identidad. En el eje direccional de la mirada (mirada comportada) se afinca una de las patas del coloso, en el fragmento y el lenguaje, la otra. Ambas cosas son una unidad: mirada que ve, ha visto $\mathrm{o}$, por menos, se esfuerza para garantizarse a sí misma el ver y para reafirmar el haber visto, del mismo modo que, lenguaje y fragmento. Es en ese dejar ver la aspiración y el trazado final, aunque "sólo como insinuación" toma cuerpo la primera dirección-luz de lo discursivo, dirección-luz, entonces en forma de: 


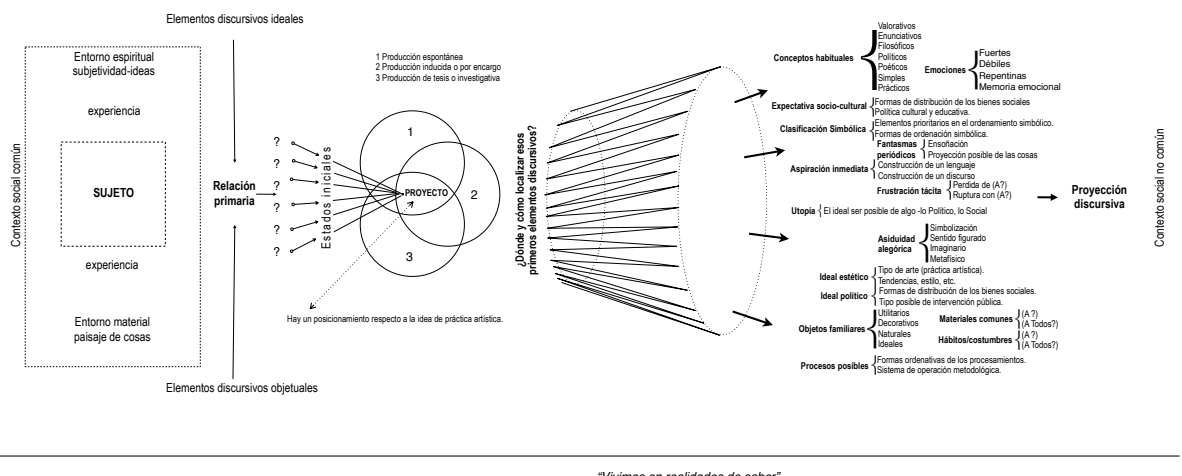

Figura 16: Esquema primeros elementos discursivos

\subsubsection{Contenedores genéricos de elementos discursivos}

Conceptos habituales - Objetos familiares - Asiduidad alegórica - Fantasías periódicas - Utopía - Emociones - Aspiración inmediata - Frustración tácita - Ideal estético - Ideal político - Expectativa socio-cultural - Clasificación Simbólica - Materiales comunes /-Hábitos y costumbres /-Procesos posibles.

- Conceptos habituales

$\triangleright$ Valorativos - Enunciativos - Filosóficos - Políticos - Poéticos - Simples - Prácticos

- Objetos familiares

$\triangleright$ Utilitarios - Decorativos - Naturales - Ideales

- Asiduidad alegórica

$\triangleright$ Simbolización - Sentido figurado - Imaginario - Metafísico

- Fantasías periódicas

$\triangleright$ Ensoñación - Proyección posible de las cosas

- Utopía

$\triangleright$ El ideal ser posible de algo -lo Político, lo Social

- Emociones

$\triangleright$ Fuertes - Débiles - Repentinas - Memoria emocional

- Aspiración inmediata

$\triangleright$ Construcción de un lenguaje - Construcción de un discurso 
- Frustración tácita

$\triangleright$ Perdida de (A?) - Ruptura con (A?)

- Ideal estético

$\triangleright$ Tipo de arte (práctica artística) - Tendencias - Estilo - Género

- Ideal político

$\triangleright$ Formas de distribución de los bienes sociales - Tipo posible de intervención pública.

- Expectativa socio-cultural

$\triangleright$ Formas de distribución de los bienes sociales - Política cultural y educativa.

- Clasificación Simbólica

$\triangleright$ Elementos prioritarios en el ordenamiento simbólico - Formas de ordenación simbólica.

- Materiales comunes

$\triangleright$ (A?) (A Todos?)

- Hábitos y costumbres

$\triangleright$ (A?) (A Todos?)

- Procesos posibles

$\triangleright$ Formas ordenativas de los procesamientos - Sistema de operación metodológica.

\subsubsection{Condicionales previos a los elementos discursivos}

La detección o localización de los elementos discursivos no tiene lugar de forma espontánea; su localización es de cierto modo una construcción determinada por la especificidad de una serie de condicionantes de todos los tipos, pero básicamente por aquello propios de la especificidad de producción. Así, son tres los parámetros iniciales en la armazón de la idea de idea de proyecto de obra y están estrechamente relacionados con los avances propios en la también armazón del tipo de análisis del plano de triangulación operacional, puesto que ellos, por el carácter condicionante que los constituye, permiten la entrada como tal en la especificidad del análisis: En ese sentido la tensión, dimensión o complejidad propia de la condicionalidad del parámetro de producción determinará la complejidad y dimensión del análisis y de la articulación del plano de triangulación operacional. A esos parámetros los hemos llamado genéricamente condicionales: 
- Condicional de producción espontánea

- Condicional de producción inducida o por encargo

- Condicional de producción por tesis o investigativa

CuADRo 4

DESDE LA "PIEZA" A LA "OBRA": DOS SISTEMAS DE PRODUCCIÓN Y RECEPCIÓN DEL ARTE

\begin{tabular}{|c|c|c|}
\hline Aspecto & $\begin{array}{l}\text { Antiguo sistema del arte } \\
\text { (mecenazgo/encargo) }\end{array}$ & $\begin{array}{l}\text { Nuevo sistema de las } \\
\text { "bellas artes" } \\
\text { (mercado libre) }\end{array}$ \\
\hline Producción & Trabajo concreto & Trabajo abstracto \\
\hline Producto & Pieza & Obra \\
\hline Representación & Imitación & Creación \\
\hline Recepción & Uso; disfrute & Intercambio; contemplación \\
\hline
\end{tabular}

Figura 17: Desde la «pieza» a la «obra»: dos sistemas de producción y recepción del arte. (Cuadro de Becq) 
$\triangleright$ Condicional de producción espontánea: El proyecto aparece, brota supuestamente acabado, cual una entidad lista —en su ser idealpara devenir situación procesual o posibilidad de estructuración de la cosa. Este caso, al parecer el de menos índole teórica, es sin embargo, en su efectividad, el que con más notoriedad pone de manifiesto el aparato metodológico, el recurso experiencial, el oficio, la cultura, el conocimiento, sabiduría del hacedor, etc..

Ejemplo: La pintura Primitiva -Escuela de Solentiname.
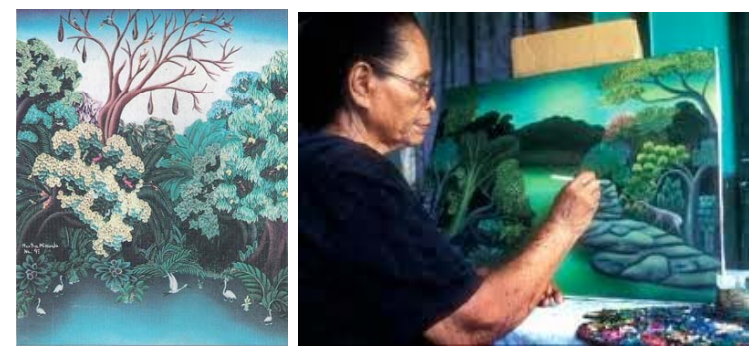

Figura 18: Obras de Marta Miranda y Elba Jiménez 
$\triangleright$ Condicional de producción inducida o por encargo: El enunciado básico o la condición ideal de tipo estructural o de la direcciones temática, ha sido decidido por una tercera persona o institución, siempre al margen del, o de los sujetos productores: esto se limita, generalmente, al tema, materiales, las dimensiones o lugar de ejecución o de recepción.

Ejemplo: Obras del muralismo Mexicano

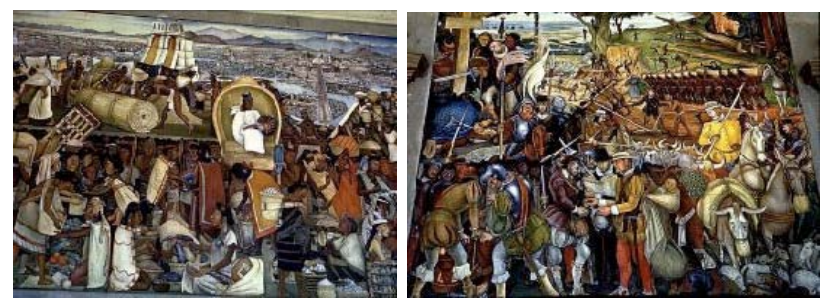

Figura 19: Diego Rivera. Brading of Indians e Historia de México, 1929-1945. Fresco. Palacio Nacional de México

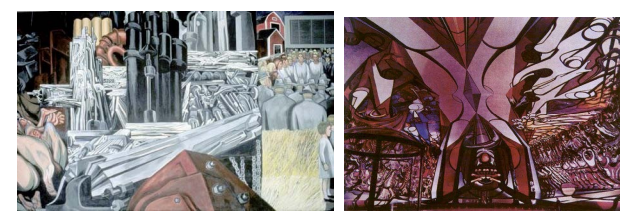

Figura 20: Justo Clemente Orozco. Épica de la civilización Americana, 1932-34. Baker Library. New York. David Alfaro Siqueiro. Humanidad vs. Cosmos, 1964.

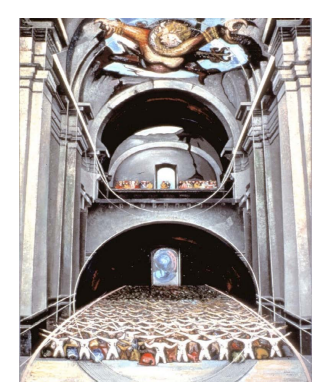

Figura 21: David Alfaro Siqueiro. The Devil in the Church, 1947 
$\triangleright$ Condicional de producción por tesis o investigativa: Definen generalmente el posicionamiento ante o respecto a la cosas en términos cognoscitivos: idea del arte, del objeto artístico, de lo estético, de la estética, de la política, de lo político, etc. -la investigación, el discurso y la producción, siempre discurren en la dirección supuesta por la hipótesis o idea de mundo de vida, por tanto discurre como conocimiento.

Ejemplos: Marcel Duchamp, Robert Smithson, Joseph Beuys.
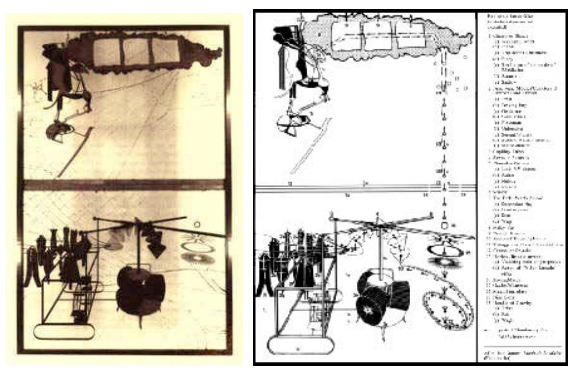

Figura 22: Marcel Duchamp. La mariée mise à nu para ses célibataires, même (El gran vidrio), 1915-23, Nueva York. Fracturada en 1926, restaurada en 1936 - Esquema de los elementos de El gran vidrio, por Jean Suquet, 1998.
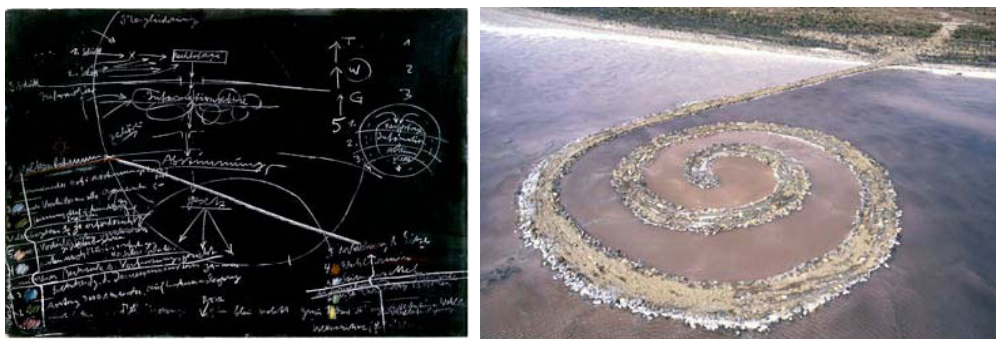

Figura 23: Joseph Beuys. Unterrichtstafel aus dem Büro für Direkte Demokratie (Blackboard from the Office for Direct Democracy), 1971 - Robert Smithson. Espiral Jetty, 1970. Gran Lago Salado, Utah. 
$\triangleright$ Generar o establecer una relación objetual a partir de la elección y análisis de tres verbos.

Verbos seleccionados $=i$ ?

Problema $\mathbf{N}^{0}$ 1: ¿En qué elemento de la selección ha de centrarse el análisis?

- En el caso de que los elementos elegidos hayan sido los verbos, el análisis debe partir de dichos verbos.

- En el caso de que los elementos elegidos hayan sido objetos, el análisis debe partir de dichos objetos.

Problema $\mathbf{N}^{\circ}$ 1a: ¿De ser conceptual la naturaleza del elemento elegido, qué dirección constitutiva deberíamos emprender?

- En el caso de que la naturaleza del elemento elegido sea conceptual, la naturaleza primera del acto constitutivo ha de ser conceptual, abierta; ha de suponer estados conceptuales o evocativos de las cosas o de las relaciones de cosas, por tanto ambientes, temporalidad, espacialidad o dimensiones, emociones.

Problema $\mathbf{N}^{\mathbf{0}} \mathbf{1 b}$ : ¿De ser objetual la naturaleza del elemento elegido, qué dirección constitutiva deberíamos emprender?

- En el caso de que la naturaleza del elemento elegido sea objetual, la naturaleza primera del acto constitutivo ha de ser objetual, 
abierta a la objetualidad o ha de suponer estados de relaciones objetuales, por tanto a relaciones de fisicidad, volúmenes, distancias, agrupamientos, divisiones, repeticiones.

\subsubsection{Solución al problema 1}

$\triangleright$ Partiendo del supuesto de que los verbos elegidos son "anudar, atravesar, relacionar" y de que el objeto seleccionado para establecer la relación es el objeto sábana, tendríamos necesariamente que centrar nuestra atención reflexiva o de análisis en el objeto sábana, en tanto que:

- Las acciones verbales sólo se cumplimentan en relación a un objeto o cosa.

- El objeto sábana es una objeto resuelto; con estructura, funciones y significados claros.

- Por la capacidad variable de sus funciones (sus usos comunes pueden variarse, ser alterados o ser sustituidos).

- Porque la naturaleza del propio objeto sábana nos obliga a hacer una utilización adjetivada de los verbos inicialmente elegidos.

\section{Ejemplo de actuación:}

$\triangleright$ Ejemplo de actuación (de puesta o establecimiento de una relaciónacción de significación) a partir de la elección del objeto sábana y de los verbos "anudar, atravesar, relacionar":

- La sábana anudada.

- La sábana agujereada y luego siendo atravesada con trozos extraídos de otras sábanas. 
- Varias sábanas dispuestas de tal manera que se pueda leer la palabra "relacionar".

\section{Esquematización del ejemplos}

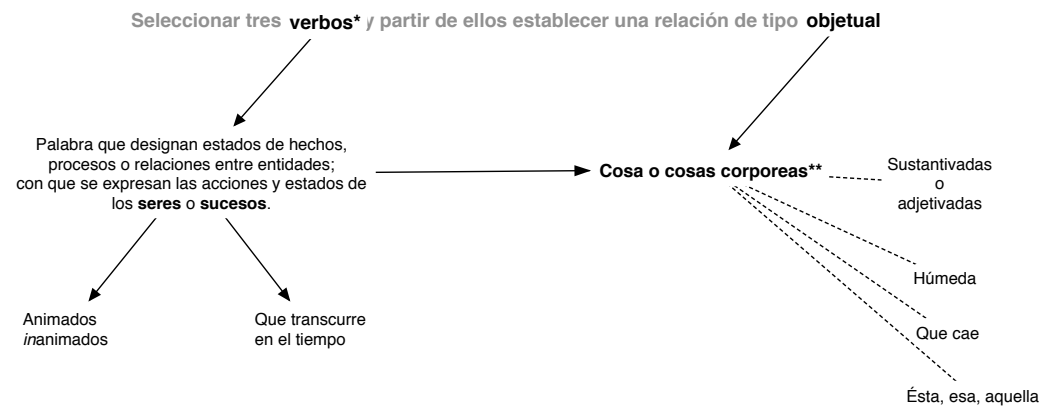

Figura 24: Esquema de comportamiento ejemplo 1

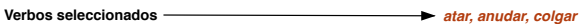

Problema: ¿En qué elemento de la selección ha de centrarse el análisis?

- En el caso de que los elementos elegidos hayan sido los verbos, el análisis debe partir de dichos verbos.
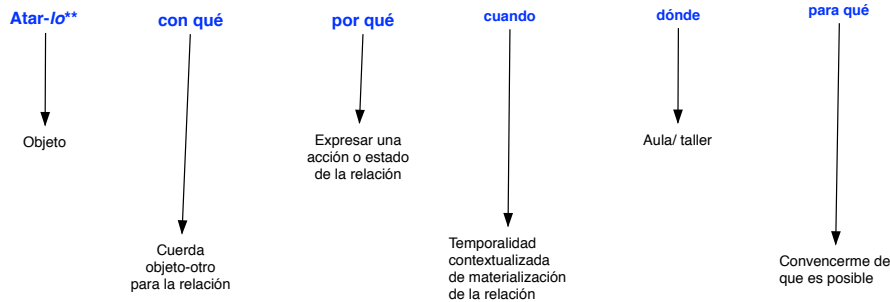

Figura 25: Esquema de comportamiento ejemplo 2 
Verbos seleccionados

Colocar, fotografiar, imprimir

Problema: ¿En qué elemento de la selección ha de centrarse el análisis?

- En el caso de que los elementos elegidos hayan sido los verbos, el análisis debe partir de dichos verbos.

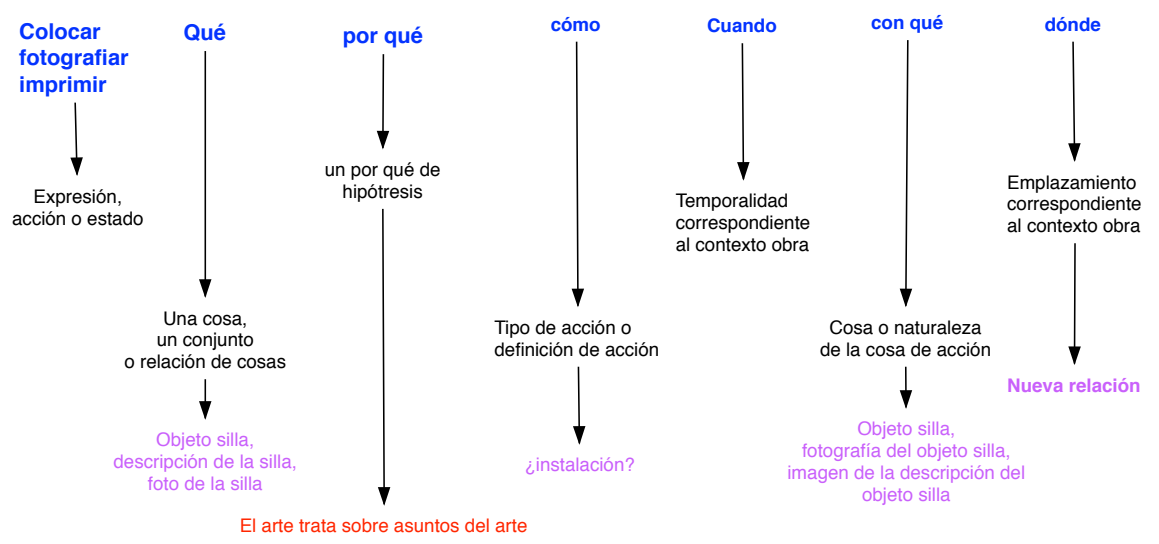

Figura 26: Esquema de comportamiento ejemplo 3
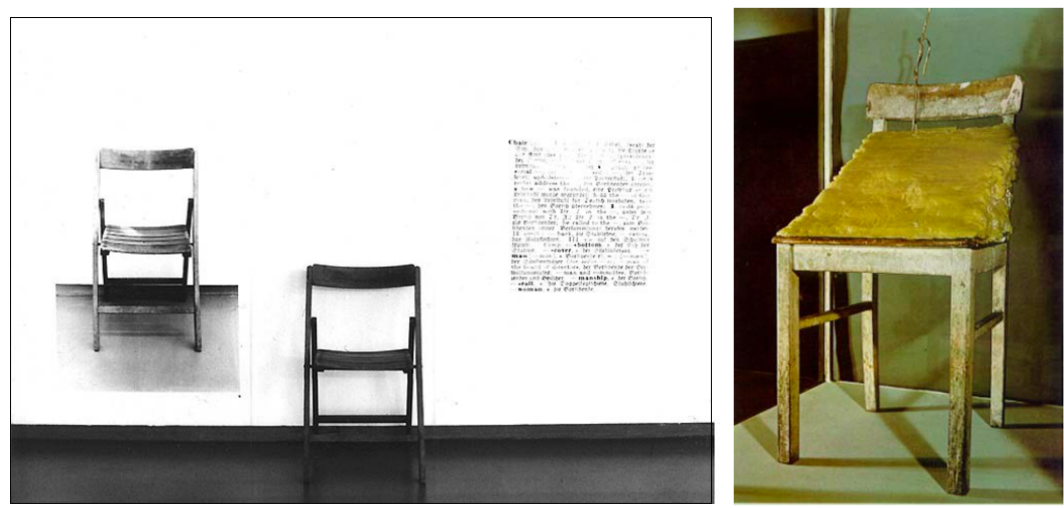

Figura 27: Joseph Kosuth. Una y tres sillas, 1965 - Joseph Beuys. Silla de grasa, 1963 


\subsubsection{Esquematización de comportamiento}

Esquematización de comportamiento de las relaciones de elección de los elementos discursivos, sujeto artistas (hacedor) y el entorno de mundo de vida.

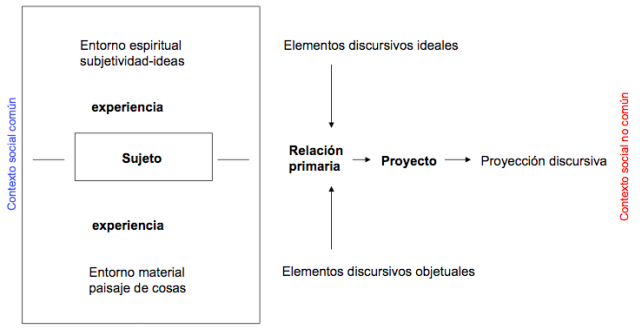

Esquema $7^{\circ} 1$ de la elección y articulación de los primeros elementos discursivos

Figura 28: Estado cognoscente del paisaje social común y acción cognitiva individual para la detección de los elementos discursivos.

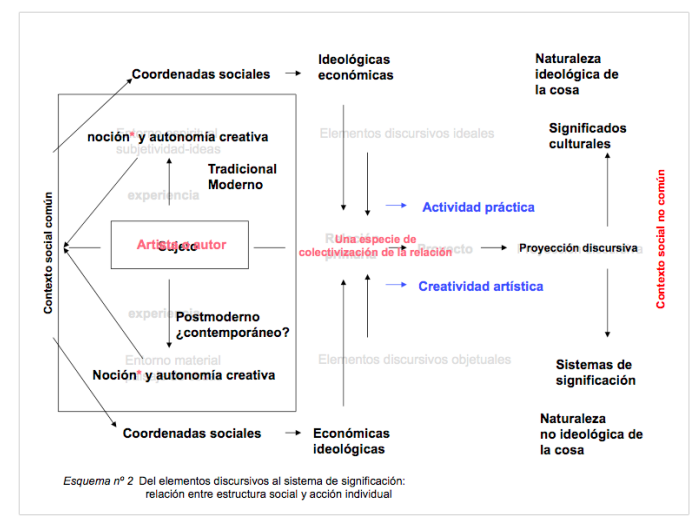

Figura 29: Del elemento discursivo al sistema significación: resultado de relación 'estado cognoscente' de la estructura social y 'acción cognitiva' individual 
3.12.3 Niveles esquemáticos de la idea de proyecto.

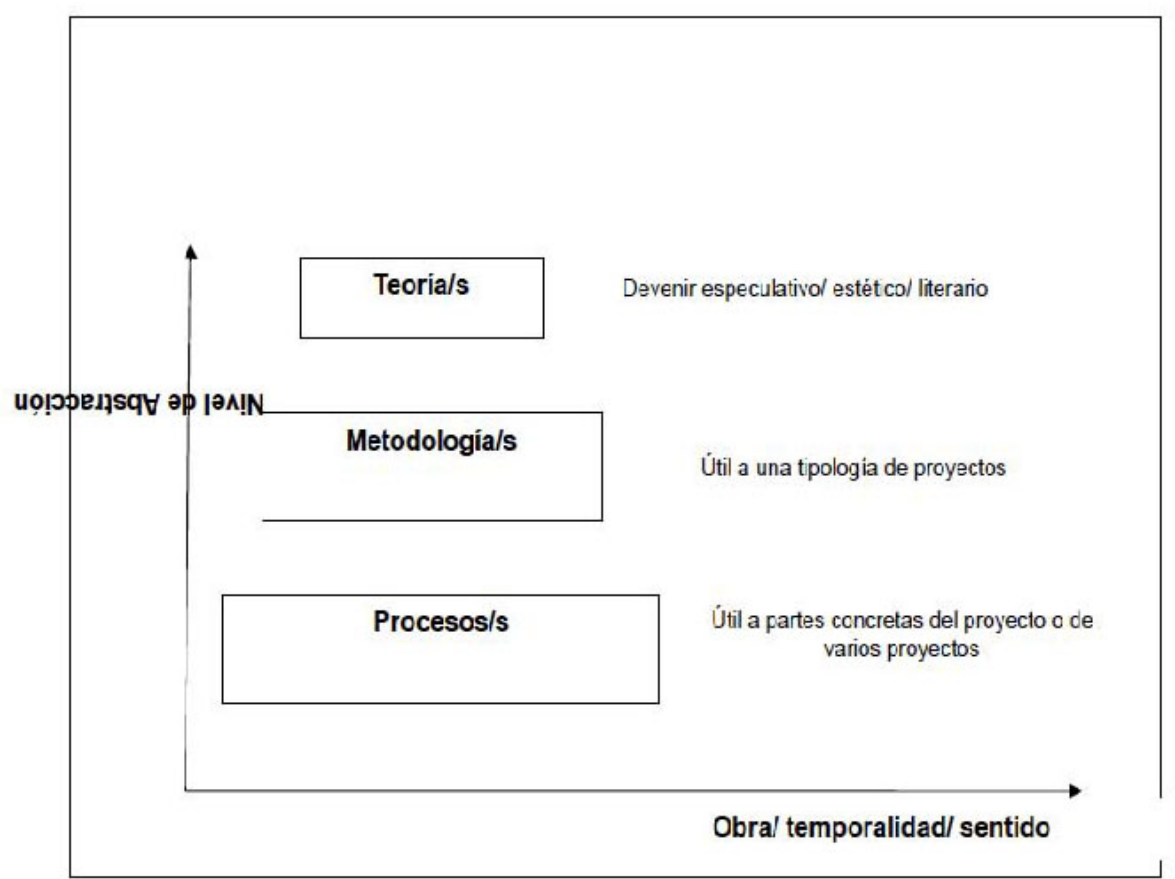

Figura 30: Niveles esquemáticos de la idea de proyecto

Por tanto, la Detección y Selección de los elementos discursivos son posibles si:

-Hay un posicionamiento respecto a la idea de práctica artística.

-Una orientación genérica, respecto al ámbito procesual: pintura, escultura, etc.

-Localizado el parámetro inicial de la construcción del proyecto.

3.12.4 Esquema o diagnóstico de los elementos iniciales

Esquema o diagnóstico de los elementos iniciales en la relación Proyecto de inserción socio-cultural. 
Partiendo del supuesto de una especie de semántica del fragmento ya mencionado, o si se quiere, de la compresión de que a partir de determinadas concatenaciones de materiales, conceptos, hechos, relaciones autónomas -sean imágenes, sonidos, formas, ámbitosemerge el significado, entendemos el proyecto como una relación, como un anclaje entre partes equilibradas de significación, de ámbitossistemas de producción de criticidad cognitiva. Aunque podemos hablar de elementos discursivos como si fuesen entidades separadas, existen solamente en cuanto componentes de la idea de obra: como inductores potenciales de funciones semánticas, por un lado y, por otro, como referencias exteriores a la mismidad, la idea, como subtextos de supuestos implícitos (de proposiciones) sobre la naturaleza de la realidad que la envuelve o la posible realidad de acogida. En ese sentido el desglose simple -en esta frecuencia de cosas siempre estaríamos hablando de esquematizaciones- de la base misma del proyecto, haciendo visible una más que segura retícula interior, de conductos semánticos, desde los que es posible extender y ampliar el proceso de ideación estratégica y, de la mano, hacerse con los indicios de la naturaleza proyectual de la obra, aunque también sobre las nociones y límites críticos de su propio conocimiento.

\section{Esquema textual de la iniciación del proyecto.}

Antes de comenzar, debería necesariamente haberse respondido a la cuestión de ¿En virtud de qué construimos una obra de arte? o visualizando la cuestión de otra manera ¿Qué constelación de cosas -ámbito, necesidad, expectativa, cultura- ha quedado resuelta, o hemos resuelto, como para que tomemos la decisión de construir una obra de arte, o para que, mediante el agenciamiento del amplio y extravagante instrumental de la práctica artística hayamos determinado construir algo relacionado con él? Sin duda, una cuestión de honda complejidad, que como se menciona en las línea anteriores de algún modo deberían, para entonces, tener una también compleja respuesta. ${ }^{* *}$ Supuesta la respuesta, volvamos al esquema textual del proyecto. ${ }^{* *}$

El primer conducto Proyecto de inserción socio-cultural, cumple la función de anclaje disciplinar, de figura coordinativa de la práctica o, si se 
quiere, de transbordador disciplinar para la puesta en práctica de la idea como segundo conducto en la relación estratégica. El simple análisis etimológico de uno o de ambos conductos -siendo uno y otro un par de elementos discursivos- harían inmediatamente visible una extraordinaria cadena de elementos discursivos sucesivos, óptimos a la vez para entrar en la cadena experiencial del análisis. 
Ejemplo o: Esquematización de la puesta en análisis de la relación de conductos "proyecto de inserción-socio cultural".

PRoyecto: Plan, Intención, Deseo, Aspiración, Propósito, Ideal, Designio.

Plan Procedimiento, Técnica, Regla, Método, Régimen

Intención Mira, Fin, Finalidad, Objetivo

Deseo Ambición, Pretensión, Avidez, Apetito, Codicia, Esperanza

Aspiración Anhelo, Sueño, Apetencia

Propósito Intento, Empresa, Plan

Ideal (1) Cosa ideada, utopía, (2) Excelente, Perfecto, Absoluto, Magnífico, Correcto, Completo, Espléndido

Designio Intento, Mira, plan INSERcióN: Introducción, Inclusión, Implantación, Encajamiento.

Introducción entrada, (prologo, preámbulo)

Inclusión fijación, penetración, colocación, instalación, publicación

Implantación fundación, creación, institución, formación, establecimiento, constitución, organización

Encajamiento ajuste, ensambladura, articulación, enchufe, enganche, engranaje

IDEA $^{103}$ : Mediante un procedimiento " $X$ " introducir o dar solución a " $X$ " cuestiones y exponer el conjunto de los resultados $=i$ ?

103 Entendemos «idea de idea de proyecto de obra» como un constructo, y en tal sentido, como algo intangible que necesita ser deducido, estructurado y montado, a través de un proceso determinado de categorización para que a su vez pueda ser interpretado, representado o activado. 


\section{Proyecto-inserción}

Los proyectos de inserción promulgan:

1- Una visión ampliada del creador intelectual, pensándosele como un oficiante cultural o un hacedor.

2- Suponen la creación de una sociedad (entrar en ella), entendida y publicitada no como una institución, sino como un "modo de obrar", a veces con propósitos de laboratorio.

Proyecto - Inserción

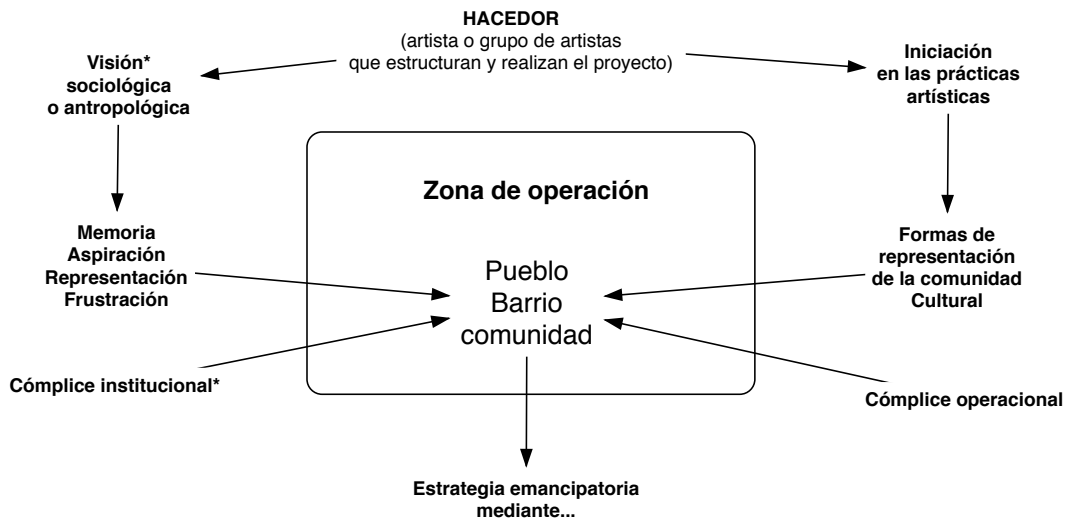

Figura 31: Esquema funcionamiento I 
Un proyecto de inserción generalmente supone una estrategia en equipo.

Ejemplo 1:

PROYECTO PILón, de Abdel Hernández:

Idea base: "Con el triunfo de la revolución se pone en práctica la idea de crear nuevos pueblos y comunidades mediante el agrupamiento en cooperativas de los núcleos familiares que vivan dispersos en toda la zona oeste de la Sierra Maestra. Nuevos poblados que a pesar de las infraestructuras de las que eran dotados carecían, en origen, de una memoria histórica-regional (tradición, folklore, etc.)".

Objetivo: Construir y dotar de una leyenda a una de esas nueva comunidades o pequeño poblado.

Equipo de trabajo: Varios artistas plásticos, un sociólogo, un periodista, y un economista.

Ejemplo 2:

PRoyecto "Desde el PUente", de Abdel Hernández y Félix Suazo:

Idea base: Toma como punto de partida la certeza de que en el contexto latinoamericano el arte y la cultura posee formas de participar y de actuar específicas; por lo que el proyecto, se inspira básicamente en las otras maneras de mover el significado, de intercambiarlo y de promoverlo.

Objetivo fundamental: La creación de espacios culturales donde se relacionen y comuniquen científicos y artistas, tecnólogos, artesanos, críticos y promotores. Propiciar enlaces y conexiones entre oficiantes culturales. Generar a partir de esos enlaces todo el material necesario para armar exposiciones, eventos. etc.

Equipo de trabajo interdisciplinar: Varios artistas plásticos, dos críticos de arte e investigadores, una periodista, y un antropólogo. 
Ejemplo 3

PROYECTO NADA, de Bárbaro Miyares.

Proyecto de Inserción

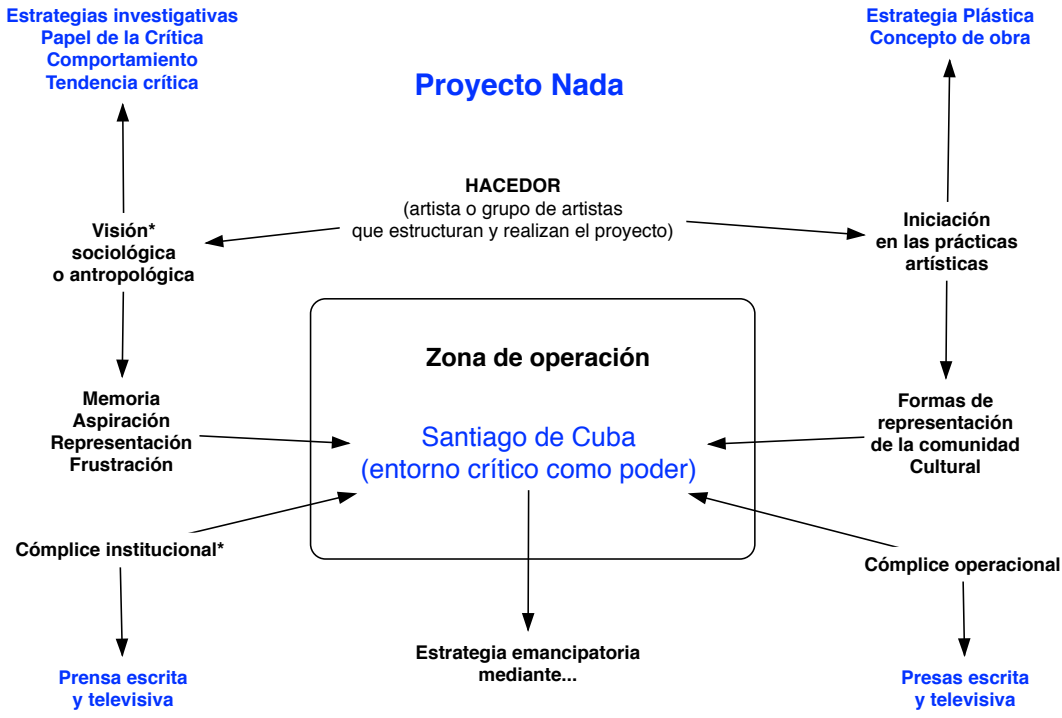

Figura 32: Esquema de funcionamiento II

Idea base: En los años ochenta se estaba dando un fenómeno de una magnitud cultural históricamente significativa, como el de la mirada crítica del Arte Plástico Cubano. En tal sentido, toda la isla era como una especie de maquinaria de producción y renovación de la visión, el sentido crítico y el papel del arte; sin embargo, las estructuras valorativa y de distribución del poder, se habían visto superado por las dimensiones y carácter crítico de las producciones de los artistas jóvenes. Así pues, en dependencia de las regiones y dinámicas culturales, las crítica adolecía de una preparación 
adecuada para el entendimiento, defensa y distribución de los productos plásticos.

Objetivo: Generar un evento expositivo que, haciendo uso de la historia del arte, tanto universal como regional, incordiara (pusiera en entredicho) la preparación teóricometodológica de quienes ejercían de censores, legitimadores y distribuidores de los productos y bienes artísticos y culturales. La referencia contradice la calidad de la opinión y de la crítica.

Tiempo duración proyecto: 1 Semana. + 1 semana previa de difusión.

Estrategia divulgativa intensa que comprende: la Prensa escrita, radial y televisiva, anuncios y carteles. Semana 2: Inauguración que comprende la presentación del Espacio de la galería vaciado de objetos -en la galería no se expone nada. Durante los siete días restantes va tomando cuerpo la configuración de la exposición. Día tras día cambian y evolucionan las obras, las referencias a la historia del arte, el espacio, etc. Día 7: la exposición aparenta estar lista para ser inaugurada o expuestos, entonces se convoca a la clausura de la misma. Todos los objetos y obras han de ser destruidos.

Equipo multidisciplinar: Dos artistas plásticos, un grupo de actores teatrales, un poeta, un crítico de arte y un periodista.

Ordenación expositiva del proyecto: autodestrucción. 

Parte IV

CONCLUSIONES 



\section{A MODO DE CONCLUSIONES}

\section{4}

"El conocimiento consiste en saber que la reflexión no se puede terminar. (...) el conocimiento no es aprender acerca de, sino aprender de. El conocimiento no es una sustancia o un contenido que se encuentra "ahí afuera" esperando a ser apropiada, sino que (...), afecta a ese aprendizaje desde la práctica del análisis cultural interdisciplinar."

Mieke Bal 


\subsection{DE LA PRAXEOLOGÍA NECESARIA}

A pesar de que Renée Bédard inscribe su análisis sobre el perfil de las especificidades de Occidente en el marco de la Administración, el alcance práctico de su reflexión sobrepasa ese radio preciso y permite -al menos a base de traslaciones teórica- presuponerla útil para el también análisis de otras áreas disciplinares del conocimiento. A decir, desde interpretaciones diversas, queda expuesto como estructura base (en forma de trabajo analítico detallado) al conjunto de aquellos intelectuales que no sólo orbitan en torno al pensamiento administrativo sino que mantienen una vinculación estrecha con el conocimiento, sus formas de análisis, así como con las formas de su distribución como es el caso de la educación.

En todo caso lo que pretendemos es -apoyados en el conjunto de sus análisis-, reforzar nuestra idea de la necesidad de implementar también un perfil, aunque en el plano curricular, orientado hacia el conocimiento praxeológico en nuestros sistema educativo en general y del estudiante de Bellas Artes en particular. El valioso trabajo de Bédard se inscribe en un esfuerzo de indagación, descifrado análisis e interpretación de lo que ella ha llamado "La especificidad de Occidente y su Administración", "El lugar del ser humano en el campo de los estudios y de las prácticas administrativas" y "Los fundamentos teóricos del pensamiento y del conocimiento administrativo" (Bédard, 1996) como contexto en el que su rombo filosófico -base referencial también para nuestra propuesta- ha sido constituido y por lo tanto tiene lugar. 


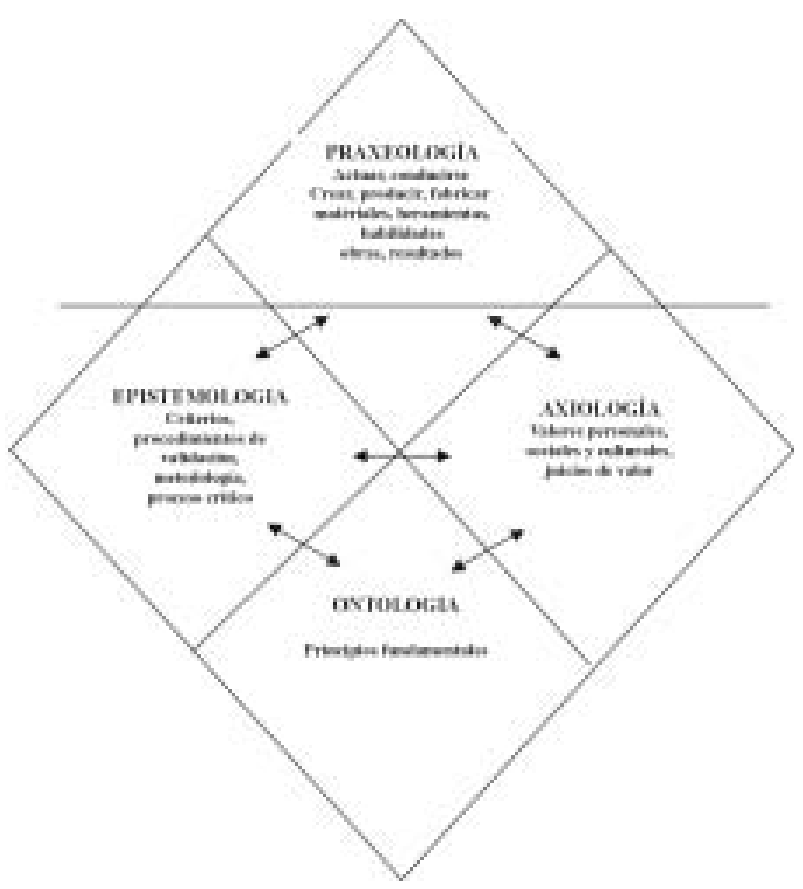

Figura 33: El rombo filosófico de Bédard

\subsubsection{El marco}

El marco en el que desarrollamos nuestro análisis de idea lo caracteriza eso que el sociólogo norteamericano Daniel Bell ${ }^{1}$ ha llamado "la sociedad del conocimiento" en referencia a los cambios que se han producido en el plano económico y que van desde una economía industrial a una economía postindustrial. Ponemos nuestro acento en un marco (por ejemplo, como el de la economía postindustrial)

I Bell, Daniel El advenimiento de la sociedad del conocimiento. Madrid: Alianza Editorial. 1976.

2 En su libro de The Coming of a Post-Industrial Society, Daniel Bell describe un cambio económico que ya había empezado: desde una economía industrial en que la mayoría de la gente estaba ocupada en producir cosas, a una economía postindustrial donde la mano de obra se iba concentrando cada vez más en los servicios, las ideas y la comunicación. 
en el que el énfasis regulador de la productividad económica recae gradualmente, por un lado en las personas, y por otro, con más énfasis, en las instituciones productoras de conocimiento: por tanto, nuestro acento descansa en el supuesto de que la mano de obra se ha ido concentrando cada vez más en los sectores de servicios, las ideas y la de comunicación; a decir, en el dominio de la ciencia, la tecnología, la investigación y el desarrollo. "Vivimos una economía del conocimiento, de una sociedad del conocimiento" afirma enérgicamente Andy Hargreaves en el prefacio de su libro Enseñar en la sociedad del conocimiento ${ }^{3}$, antes de diagnosticar y advertir sobre los males de la estimulación de la economía del conocimiento basada y dirigida únicamente a la creatividad y la inventiva: "estimula el crecimiento y prosperidad, pero su incansable búsqueda del beneficio y del interés propio también fuerza y fragmenta el orden social. Junto con otras instituciones públicas, nuestras escuelas, por lo tanto, deben promover la compasión, la identidad cosmopolita y la comunidad que compensarán los esfuerzos más destructivos de la economía del conocimiento. La economía del conocimiento está principalmente al servicio del bien privado. La sociedad del conocimiento también abarca el bien público. Nuestras escuelas deben preparar a los jóvenes para ambas".

Una sociedad del aprendizaje debería ser lo propio de la sociedad del conocimiento: llevar al máximo el procesamiento de la información y el conocimiento, como de igual manera estimular la creatividad y la inventiva de modo que el aprendizaje ha de recobrar, como también el armazón curricular de la enseñanza, su potencia y "misión social de dar forma a la vida y cambiar el mundo." 4 Sin embargo, todo aquello que se espera cree las habilidades y capacidades humanas propia de la sociedad del conocimiento, y que permitan a los individuos [y sus organizaciones] tener éxito y sobrevivir, parece estar claro en términos económicos y estratégicos pero no en términos de la enseñanza y de la configuración

3 Hargreaves, Andy. Enseñar en la sociedad del conocimiento. Barcelona. Ediciones Octaedro, 2003.

4 “En este segundo supuesto, la enseñanza y los docentes irán mucho más allá de las tareas técnicas de conseguir unos resultados aceptables en los exámenes, para hacer de la enseñanza, de nuevo, una misión social de dar forma a la vida y cambiar el mundo." Ibídem. 
correcta de sus planes curriculares orientados a la persona (a lo sensible) y con una claro perfil y carácter orden humanista.

Según nuestro modo de ver, el gran problema de la critica a la "sociedad del conocimiento" tiene su origen en el marcado carácter administrativo de los propios perfiles críticos, de tal modo, que la propia voluntad crítica queda disuelta en el carácter casi empresarial de los supuestos pensados para la enseñanza -si bien de cara a solventar la idoneidad del individuos respecto a su sociedad, y no ya, desde la persona en su relación crítica y sensible respecto a su mundo de vida. La formación de un hombre nuevo, en término de su encajamiento productivo y de fe, y por tanto, en términos de su construcción respecto a una sociedad determinada, históricamente no parece haber conducido hacia los deseados bienes programáticos [el cumplimiento pleno de la utopía de perfección], en tanto que tal programación, en el sentido de ordenación económicamente conveniente, siempre ha tenido que prestar atención [introduciendo discontinuidades 5 , rupturas y censuras artificiales], como es obvio, al carácter de orden programático del proyecto de sociedad y, por lo mismo, a su naturaleza administrativa, que como consecuencia generalmente ha devenido en el abandono o descuido de las personas y de sus sistemas de referencias y de tradiciones.

Sociedad del conocimiento más que una realidad es un eslogan, $\mathrm{y}$, así mismo, la instauración no consensuada de un régimen de verdad que como siempre favorece a los mismos. Hargreaves recuerda que en el año 1973 la crisis del petróleo y derrumbamiento de la economía aceleraron el fin de las presunciones educativas de occidente (en sentido general aunque con especial énfasis las de los países y economías más desarrolladas) trayendo como consecuencia que la educación pasara de ser la solución, a convertirse en el problema. La crisis de 1973 guarda un cierto paralelismo con la situación socio-económica y política actual, y del mismo modo se está produciendo un desmoronamiento del estado hasta ahora considerado de bienestar, el índice de crecimiento

5 Usamos discontinuidad en el sentido foucaultiano de rompimiento o desconexión de un discurso como régimen de verdad. 
demográfico retrocede, la inmigración disminuye como síntoma de la perdida de atractivo de nuestras economías, la mendicidad crece de la misma manera que crece el paro laboral, es notable la pérdida de atracción de trabajo docente como indicio de la fortaleza de nuestros sistemas educativos, y por último, como síntoma claro de un estado generalizado de crisis, hace patente la caída de la población y del entusiasmo de los estudiantes en forma de fracaso escolar. Esta similitud en cuanto a la dimensión de la crisis nos permite reducir dos cuestiones de orden estratégico que plantea: a) que los síntomas y criterios históricoeconómicos propios de las crisis anteriores a la de 1973 y los de la crisis del 73 misma, parecen no haber sido considerados en profundidad por los agentes, técnicos y estrategas de las nuevas economías, y b) la falacia del diseño de los proyectos y sistemas educativos de los estados y países basados en criterios administrativos (gestión del conocimiento en términos estrictamente económicos), y no en términos profundamente humanísticos y en consecuencia orientados a las personas.

\subsubsection{La observación de Bédard}

Nuestra idea toma apoyo en la observación que Bédard hace aún en el momento mismo de indagación respecto a su tesis y que ella posteriormente ha considerado como un hallazgo: "Mientras que las ciencias exactas descartaban lo particular y lo individual, las ciencias humanas demandaban una actitud opuesta, especialmente con respecto a las manifestaciones de orden simbólico, y exigían además una atención minuciosa, no solamente a los contextos específicos en los cuales los eventos y los hechos se producían, sino también a sus antecedentes." ${ }^{6}$ Es en esa diferenciación, en ese juego de descartes y de demandas donde nuestra atención encuentra su centro, en esa fuerza de poder que -unas veces potenciada y otras en clara debilidad-, articula las formas, cauces y alcances de la distribución del conocimiento.

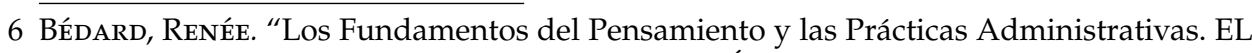
ROMBO Y LAS CUATRO DIMENSIONES FILOSÓFICAS, publicado en AD-MINISTER Universidad EAFIT Medellín Número 3 jun - dic 2003. Pág. 69 
"Cada sociedad tiene su régimen de verdad, su política general de lo verdadero", argumenta Foucault 7 , y lo hace no ya como denuncias o como críticas de un sistema de cosas sino como ontología, como denotación de aquello otro que además tiene espacio y proceso propio en el sistema, que tiene lugar allí y ha de ser necesariamente atendido, estudiado y pensado como una posibilidad en términos de su instrumentalización.

Esa verdad [con carácter de régimen] constituye un sistema de procedimientos distributivos y de enclasamiento de las producciones, operaciones y prácticas discursivas localizadas en el radio de influencia de su poder. Es en esa verdad y en su constituirse sistema de procedimiento donde adquieren perfiles propios las formas de descartes, tanto de lo particular y como de lo individual, propias de la ciencias exactas y donde también lo adquieren, entonces como oposición, las voluntades de su demanda respecto a las manifestaciones orden simbólico.

El sistema de procedimientos distributivos a través de estrategias de enclasamiento permite únicamente [con la activación de su visualización] que funcione como régimen de verdad o mecanismo operacional y regulativo, aquel modelo de discurso que para sí es aceptado, o como afirma Arturo Barraza $^{8}$ en su clasificación e interpretación de las formas de comportamiento de los regímenes de verdad:

\section{"Este sistema de procedimientos permite: a) decir el tipo de discurso que se acepta y se hace funcionar como verdad (regulación, distribución y operación), b) los mecanismos y casos que le permiten a uno distinguir las afirmaciones verdaderas de las falsas (regulación), c) los medios por los que se aceptan cada una de ellas (producción y operación), d) las técnicas y procedimientos que otorgan valor en la adquisición de la verdad (producción y}

7 “Verdad y Poder", entrevista con M. Fontana, en: Microfísica del Poder, Ed. La Piqueta, Madrid, 1988. Pág. 187

8 BARRAZA MACÍAS, Arturo. (2005). "Saber y poder: el papel de las universidades". Odiseo, revista electrónica de pedagogía. Año 3, núm. 5. 1 de noviembre de 2005. http://www.odiseo.com.mx/2005/o7/ barraza-saberypoder.htm (ISSN 18701477). [Fecha de consulta: 2 de marzo de 2009] 
regulación) y e) el estatus de aquellos que están encargados de decir lo que cuenta como verdad (regulación, distribución y operación)". ${ }^{9}$

El hallazgo de Bédard respecto a la actitud opuesta demandada desde las ciencias humanas frente al problema de la atención de lo particular y lo individual, especialmente en aquellas manifestaciones de orden simbólico, pone de relieve una cierta perdida de operacionalidad del conjunto de las prácticas discursivas localizadas en su radio de influencia de poder. Radio de influencia y poder que alcanza al arte y lo denota en esa debilidad o perdida. Esto es, que el conjunto de discursos que produce, distribuye y regula el arte actual como sistema de procedimientos - de régimen- de verdad no alcanzan a ser vistos como dominios de referencia dentro de los cuales pueda ser concedido poder alguno y autoridad en proporción al volumen y multiplicidad de modos de prácticas que hoy tienen lugar. Pero, ¿A causa de qué? ¿Sobre qué condiciones adquiere potencia esa pérdida? Luis Camnitzer en la conferencia "La enseñanza del arte como fraude"10, impartida en el marco de su exposición en el Museo de Arte de la Universidad Nacional. Bogotá, marzo de 2012, hace dos afirmaciones de principio:

"Quiero comenzar esto con dos afirmaciones pedantes y negativas. Una es que el proceso de educación de los artistas en el día de hoy es un fraude. La otra es que las definiciones que se utilizan hoy para el arte funcionan en contra de la gente y no a su favor.

La educación formal del artista sufre de las mismas nociones que imperan en las otras disciplinas: que la información técnica sirve para formar al profesional y que después de adquirir esta información uno podrá mantener una familia. En los Estados Unidos, en donde la educación no es un derecho sino un producto comercial de consumo, esta situación es llevada al nivel de caricatura obscena. La inversión económica para recibir el diploma final de maestría, el Master of Fine Arts, en una universidad decente es de unos 200.000 dólares. Al final de este gasto, la

9 Ibídem

1o http://www.wokitoki.org/wk/1059/la-ensenanza-del-arte-como-fraude 
esperanza es vender la obra producida o enseñar a las generaciones venideras. Aún si esto no es literalmente así en otros países, el concepto probablemente funciona en todo el mundo."

\subsubsection{Camnitzer y la relación arte y enseñanza.}

Dos preocupaciones en forma de problemas son dejados ver en la contundente crítica que Camnitzer hace la relación arte y enseñanza. Por una lado una referida al ámbito curricular -que hoy se ha vuelto extremadamente problemático no sólo para las ciencias sino sobre todo para las formas de saber que por su naturaleza filosófica constituyen un nodo de saber cultural-, y que dan veracidad a la afirmación de Scheller ${ }^{11}$ sobre "el constitutivo divorcio en que viven el poder y el espíritu"; y por el otro, entonces supuesta causalmente de la estructura del sistema que la primera instaura, una que apunta a los modos de hablar respecto a mismidad de las formas y modos de prácticas. A decir, los discursos propios de la enseñanza artística, y de las propios modos de prácticas como dominio de referencia, funcionan en términos de apariencia y como formaciones tautológicas que excluyen todo principio de conocimiento por estar orientadas a la profesionalización que aleja insistentemente la constitución de un corpus reflexivo en torno al saber artístico y en general a toda voluntad de conocer y saber.

En ese sentido, su posicionamiento se orienta -contrariamente a lo que se le supone- hacia la consideración de las humanidades y de su papel clave en término estrictamente formativos, pero sin embargo lo hace no sólo hacia ellas sino también a las tradiciones empiristas propias de las prácticas artísticas (hablamos por tanto del carácter sintáctico de los modos de prácticas artísticas) y al conjunto de procedimientos, reglajes y técnicas que han permitido identificar en el tipo de saber-arte el potencial de verdad que parece legitimarlo como sistema vehicular de, y para, el conocimiento -un poder, en todo caso, para nada alejado del conocimiento sino más bien adscrito a todo el sistema de mecanismos que aseguran la potenciación del saber, "que aseguran la

11 SCHELLER, MAx. El saber y la cultura. Ediciones elaleph.com. 1999. 
formación, la inversión, la acumulación, el crecimiento del saber."12 Todo esto, aunque con tensiones, guarda una seria relación con la observación -o descubrimiento- de Bédard respecto a los descartes, demandas o pujas de los regímenes de verdad propios de las ciencias exactas y de aquellas otras cuya manifestación discurre como proyecciones de ordenes simbólicos.

\subsubsection{Una lógica de inclusión/exclusión}

El hecho de que desde un régimen de verdad se tense una lógica de inclusión/exclusión respecto a otro régimen de verdad más débil no sólo evidencia su presente como tipo de poder sobre todo basado en la especificidad conveniente de un cierto tipo de conocimiento, sino, además, hace visible el conjunto de carencias curriculares, discursivas o de actores con autoridad-que le imposibilita reconstituirse como tal en sistema de procedimiento propio y en términos del establecimiento de su propio orden-, del conjunto de aquellos otros, entonces débiles, regímenes también de verdad. Esta claro que es en el esfuerzo de constituir su propio modelo de discursividad de las propias ciencias sociales y de las manifestaciones de orden simbólico, donde es posible también encontrar la solución tanto a la incertidumbre de carácter curricular, como a la ordenación (en términos de excelencia) de la educación universitaria; esto es, que en todo aquel esfuerzo escrito (por tanto constituido ya como discurso o como enunciación de un cierto modelo disciplinar de verdad) o en todo esfuerzo de su escritura, es donde de algún modo se hayan las bases, y en ese sentido la posibilidad, de disolución de dicha incertidumbre, o también en cierta forma están siendo marcados los límites operacionales de ese nuevo régimen de verdad.

En ese sentido cuando Renée Bédard intenta discernir y dibujar el perfil de las especificidades de Occidente en el marco de la administración, planta no sólo el esquema estructural y constitutivo

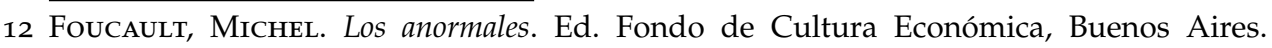
Argentina, 2007. Pág. 55. 
de occidente en el ámbito de la administración, sino la descripción funcional del ADN del occidente actual, con unas más que previsibles posibilidades de observación y de diagnóstico a través de su rombo filosófico. Renée Bédard en la introducción al texto "Fundamentos del pensamiento y las Prácticas Administrativas", refiriéndose al punto de vista de la comprensión, afirma:

"Definiéndose como la ciencia de los principios fundamentales del comportamiento humano en general, la economía aspira hoy a reemplazar la ética mientras que la administración, concebida como la ciencia aplicada de lo económico de donde aquella saca sus principios generales, tiende a invadir el campo de la ciencia política y ocupar todo el terreno de la vida pública y privada. Contrariamente a la idea corriente en la historia de las ideas según la cual esa tendencia se inscribe en la continuidad del pensamiento clásico, el triunfo actual de esta concepción hegemónica de la ciencia económica formal y su substitución de la ética, dan lugar a pensar que estamos en presencia de un verdadero cuestionamiento de los fundamentos de la sociedad occidental."13

En su intento de descripción del pensamiento actual constata la manera en que se conserva la huella de su proceso formativo en los orígenes filosóficos, y como permanecen, en oposición a las tesis en historia que argumentan a través de la revolución copernicana la ruptura con el pensamiento griego; en ese sentido argumenta:

"Occidente ha heredado de Grecia una concepción jerarquizada del conocimiento según la cual la verdad es el resultado de un esfuerzo intelectual de abstracción del mundo sensible; lo que quiere decir que el conocimiento de los principios fundamentales está en un nivel de verdad superior a aquel de las realidades concretas. En el orden del mundo terrestre, el tipo ideal de conocimiento verdadero es la matemática -la ciencia de los objetos abstractos que trata sobre

13 BÉDARD, RENÉE. “Los fundamentos del pensamiento y las Prácticas Administrativas: El rombo y las cuatro dimensiones filosóficas." AD-Minister - Universidad EAFIT. Medellín, Número 3. Junio - Diciembre 2003. 
las formas y las figuras materiales detrás de las cosas materiales-, o la física -la ciencia de los objetos concretos que trata de las leyes universales detrás de los fenómenos materiales."

La afirmación de que el conocimiento de los principios fundamentales está a un nivel de verdad superior a aquel de las realidades concreta, deduce, nos permite hacerlo desde una apretada simplificación ${ }^{14}$, la debilidad en términos de excelencia ${ }^{15}$ y de régimen de verdad, como anteriormente argumentábamos, del conjunto de aquellas manifestaciones o principios de conocimiento del orden simbólico, respecto a las ciencias no ya en lo que se refiere a sus respectivos campos de estudios sino al conocimiento mismo de sus modelos de práctica y en ese sentido respecto a los modelos y proyectos de su distribución e implantación como régimen de verdad. Sin embargo, es oportuno clarificar que dicha afirmación toma cuerpo en el análisis que Bédard desarrolla sobre la cuestión del Ser en Occidente como punto de partida de toda reflexión. A decir, el ser que existe bajo formas diversas y que cambia en el curso de los tiempos (einai), ser designado en filosofía como el "estar", y el "ser permanente y verdadero", que se busca descubrir detrás de la apariencia engañosa de la realidad caracterizado por la unicidad, la identidad y la eternidad (ón ousia), accesible sólo al espíritu.

Interrogación sobre el ser que permanece, como propia y característica del antiguo Occidente y del Occidente actual, y que hace permisible la observación siempre dualista y de mutua exclusión sobre la superioridad asignada a lo abstracto sobre lo concreto, al espíritu sobre la materia, a lo esencial sobre lo accidental, a lo general sobre lo específico así como a lo intelectual sobre lo afectivo y sensible, pero también, en términos de problematicidad, los entresijos de la debilidad

14 Decimos simplificación, porque Renée Bedard, desarrolla una larga argumentación relativa a la reflexión sobre Occidente y la cuestión del Ser como punto de partida de su investigación.

15 Aunque, en aparente anacrónico, la argumentación que damos al término excelencia transcurre en la dirección de su consolidación en el marco propio de la Universidad. Excelencia, encuentra su potencia necesaria en la afirmación de Bill Readings en su libro La Universidad en Ruinas, "La verdad de la cultura como idea organizadora de la universidad moderna apunta ya a la excelencia, por lo que los orígenes del actual estado de crisis de la universidad hay que referirlo al siglo diecinueve". 
y consistencia de unos regímenes de verdad sobre otros, aunque de igual modo, según las estrategias de redefinición, el potencial crítico albergado en la discursividad de cada principio de conocimiento y de poder.

"Una jerarquización -puntualiza Bédard en la caracterización de las cinco consecuencias de base de la distinción entre el "estar" y el Ser-, de tipos de conocimientos (epistémé, praxis, poiesis), de donde el conocimiento de los principios fundamentales y de las leyes, la matemática y la física ocupa una posición superior". Y "Una valorización de los métodos que se apoyan sobre el razonamiento abstracto, por oposición a otros modos de conocimiento como la dialéctica, la fenomenología o la hermenéutica", concluye. En la consecución de los modelos de práctica, proyección y distribución parece ser que es donde descansa la potencia de régimen de verdad de uno o otro principio de conocimiento, y por tanto en el hecho de que sea en sí, uno u otro, un sistema de procedimiento de valorización, enclasamiento y distribución, en cada una de sus partes y entonces en conjunto estable.

\subsubsection{De lo que nos interesa}

De todo esto -en función de nuestra idea de la necesidad de implementar también un perfil, aunque en el plano curricular, orientado hacia el conocimiento praxeológico en nuestros sistema educativo en general y del estudiante de Bellas Artes en particular-, lo que nos interesa es eso que anteriormente hemos llamado "la descripción funcional del ADN del Occidente actual" y que Bédard proyecta bajo la forma de un rombo que integra cuatro grandes ramas de la filosofía como son: la praxeología, la epistemología, la axiología y la ontología.

Nos interesa por tanto aquello que de algún modo describe el comportamiento y perfil general de occidente y sobre esa base ancla la pretensión del diseño curricular. Occidente insiste en la articulación de la idea de proyección curricular del conocimiento sobre la base de proyecciones e ideales de futuro y no sobre la base de aquello que caracteriza el contexto occidental en relación a otras culturas y a la problemática de su estatus, también en relación, a otros tipos de conocimiento. 
En ese sentido Bédard -como acumulaciones progresivas tendentes a la configuración de ese nuevo perfil-, describe la importancia de la dualidad platónica (mythos/logos) en la constitución histórica del pensamiento occidental:

"El advenimiento de la Razón en Occidente, lo simboliza la revolución socrática del siglo $V$ a.C. La fórmula "Conócete a ti mismo" nos muestra la afirmación de las capacidades del pensamiento humano como fuente del conocimiento y la liberación de las certidumbres trascendentes. De alli el descrédito arrojado después sobre la mitología y la teología, consideradas como explicaciones "preracionales" $y$ de menor verdad con relación a la filosofía que, ella sí, representa la expresión de la Razón y un tipo acabado de conocimiento reflexivo. Las consecuencias de esta concepción dualista mythos/logos son de diversa indole. En primer término, cuando la ciencia nueva apareció a su turno en el Renacimiento y vino a poner en tela de juicio ciertas explicaciones de naturaleza filosófica, esta forma particular de conocimiento se explicará, no como una segunda revolución mental, pues la razón ha emergido ya una vez y ella constituye el principio supremo de la naturaleza humana, sino como un tipo de conocimiento racional que se ha autonomizado con relación a las explicaciones "metafísicas". Esto pone a la filosofía en una posición inferior, de menos validez que la ciencia, y disminuye su autoridad y su jurisdicción haciéndole sufrir a su vez la suerte que había infligido a la mitología. Esta nueva manera de ver el mundo, será reforzada por el hecho que la concepción galileana de la física será considerada como una ruptura y un progreso con relación a la física griega (physica), que llevaba también el nombre de "filosofía natural". Por tal razón la concepción moderna de la ciencia será mirada como una ruptura con relación a la filosofía, lo que tenderá a desvalorizarla al considerarla un abuso del conocimiento abstracto. Finalmente, el nacimiento de la ciencia moderna aparecerá como el advenimiento de la Ciencia como modo por excelencia de conocimiento." 
Llama sobre todo la atención la posición de inferioridad de la filosofía con respecto a las nuevas ciencias que, como forma particular de conocimiento se exponen a sí mismas como racionales, como un tipo de conocimiento racional autónomo entonces de la metafísica, que pone en entredicho ciertas explicaciones de naturaleza propiamente filosóficas. Posición de inferioridad notables en el progreso con relación a la "filosofía natural" (física griega, physica) y las consideraciones de abusivas respecto al uso del conocimiento abstracto y no tanto, como ocurre con el advenimiento de la Ciencia, como "modo por excelencia del conocimiento". En ese sentido los fundamentos del pensamiento occidental actual no distan mucho de las huellas y orígenes filosóficos. El principio de fondo que Bédard percibe en relación a la actividad administrativa es, sin duda, común al ámbito y actividad de las prácticas de conocimiento del orden simbólicas, y guarda un paralelismo notable a pesar de que su descripción corresponde propiamente al ámbito administrativo:

"Percibí en el mundo de la administración una ambivalencia con respecto al ser humano. Aun si los salarios representan uno de los gastos más importantes (en la universidad por ejemplo, constituyen mas del $85 \%$ de los gastos de funcionamiento); aun si las inversiones más elevadas en materia de automatización y de tecnología no alcanzan a abolir la necesidad de la intervención humana; aun si el discurso moderno sobre el trabajo no se cansa de promover la participación, la excelencia, la eficacia y la productividad, cualidades que exigen la contribución inevitable de la creatividad personal; aun si "la economía del conocimiento" que está en vía de suplantar la economía industrial clásica reposa esencialmente sobre la "materia gris"; a pesar de todos los argumentos de importancia, es forzoso constatar que, en la filosofía que subyace al pensamiento y a la práctica administrativa, tal como se proponen actualmente, la persona es apenas más importante que los bienes materiales y es considerada ni más ni menos como una fuente de problemas, en esencia, un mal necesario." 
Ahora bien, como todo análisis, de lo que sea, plantea primero una cuestión de procedimientos, y después, un problema de índole teórico; a decir, una discontinuidad respecto al ámbito y una escrituralidad propia de su conveniencia teórica, proponemos un esquema de análisis de la relación educación-enseñanza, a partir de los supuestos defendidos por Bédard (aunque en el plano de la Administración) que son perfectamente adaptables al ámbito de la enseñanza y educación en arte, pero que sobre todo deducen la posibilidad de un diseño curricular en relación y orientado hacia la persona y con un carácter profundamente humanista. Esquema que sólo deduce la posibilidad de una observación más consistente y profunda respecto al comportamiento general de los sistemas educacionales y de enseñanza. En este sentido "escrituralidad propia" debería deducir -condicionada por la discontinuidad procedimental a la que lleva necesariamente el análisis-, la implementación de un conjunto de nuevas nociones (nuevo juego de ellas) propias del problema, y a su vez, una radical separación del también conjunto de "juego de nociones que diversifican, cada uno a su modo, el tema de la continuidad" (Foucault). De lo que se trata es de producir una separación con aquello que alimenta su unidad con una cierta tradición de deformaciones, con aquello que, en torno a la cosa analizada (en éste caso la idea de una administración educacional más que de una educación que administra), la convierte en enunciado afirmativo de una tradición nocional técnicamente limitada, o lo que es lo mismo, del conjunto de afirmaciones y negaciones que hasta entonces determinaban que la cosa es así y no de otro modo. El esquema esta basado en los siguientes supuestos:

a) En el currículum de los estudios universitarios en sentido general, el conocimiento de la persona se reduce a menudo a las nociones elementales.

b) La tendencia a administrar el personal tanto administrativo como docente, constituye una actividad común y de naturaleza general.

c) La sociabilidad o la vida en sociedad constituye un característica fundamental del ser humano. 


\subsubsection{La estrategia Praxeológica}

La estrategia Praxeológica consistiría en elaborar un enfoque orientativo que reconozca el lugar necesario, en término curricular, de un tipo de conocimiento sobre las diversas formas y modos de prácticas, que tenga en cuenta las particularidades y especificidades de la praxis (Phraxis) también como actividad de conocimiento, y su trasfondo vinculado al lenguaje en tanto que comparte una naturaleza y carácter visiblemente sintáctico. Aquí debería poder argumentarse todo aquello tratado insuficientemente respecto a las características fundamentales y propias de la naturaleza humana, en un ámbito como por ejemplo el de la enseñanza del arte en la universidad, suponiéndola en esa posición de debilidad propia de su fuerza de régimen de verdad o su indefinición en términos de ser (o parecer serlo) como tal un sistema de procedimiento de valorización, enclasamiento ${ }^{16}$ y distribución. A decir, y partimos de la propia enumeración de Bédard por ser coincidente con aquellas que consideramos como fundamentales y que de algún modo constituirían los tramos propios para la articulación del correcto perfil curricular que nos interesa, que como es evidente tiene el lado base de su diseño estructural en las manifestaciones de orden simbólicas y por tanto de carácter sintáctico: En relación al conocimiento de la razón (logos):

- Sobre "El saber o la capacidad de captar los principios explicativos, de abstraer y de buscar la verdad."17.

- Sobre "La acción metódica o la capacidad de relacionar los medios y los fines." ${ }^{18}$.

- Sobre "El debate o la capacidad de argumentar."19.

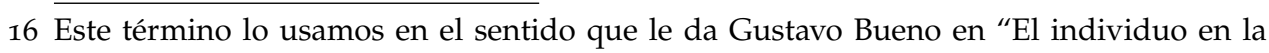
Historia".

17 Enumeración que Renée Bédar realiza en el desarrollo de “El lugar del ser humano en el campo de los estudios y de las prácticas administrativas". El lenguaje y la herramienta son las dos producciones características del homo sapiens, y conviene que se le dé una atención particular en la formación.

18 Ibíd., p. 74.

19 Ibíd., p. 74. 
- Sobre "La cooperación y el acuerdo para llegar a un orden por oposición al caos." ${ }^{\prime 20}$.

Y en relación al conocimiento de la psykhé,:

- Sobre "La afectividad o la capacidad de experimentar sentimientos y afectos, incluyendo las pulsiones (la búsqueda del placer, la sexualidad, etc.)" 21

- Sobre "La voluntad (el deseo reflexionado), de allí la capacidad de actuar $y$ de escoger en función de valores (la razón práctica)."22

- Sobre "La representación o la capacidad de sentir en sí la presencia de un objeto externo, lo que implica la intuición, la simpatía, la receptividad, la imaginación, etc." 23.

\subsubsection{La universidad actual diseña de algún modo el tipo de individuo de apoyo}

En el contexto actual de las universidades se constituyen [teóricamente así debería ser] los apoyos propios de institucionalidad que como tal las legitiman, reproducen y difunden. $\mathrm{O}$ sea, la universidad actual diseña de algún modo el tipo de individuo de apoyo (con proyección de subjetividad y una cierta organización de conceptos y tipos de enunciados) de su régimen de verdad, por lo tanto el individuo de apoyo (enclasado) capaz de difundir el conocimiento/discurso propio del modelo formativo que lo ha constituido como tal.

Ahora bien, si ese conocimiento/discurso administrado desde la universidad y considerado de algún modo como verdadero, no es pensado de base conocimiento/discurso para la persona, si aquello que lo impulsa como programa no parte en su fondo de un principio humanista propio de la actividad de saber, entonces excluye aquel conocimiento/discurso no conveniente (pues la universidad ha

20 Ibíd., p. 74.

21 Ibíd., p. 74.

22 Ibíd., p. 74.

23 Ibíd., p. 74 
cambiado de perfil y de rol: ahora es centro de gestación de política, y de poder político, como de igual modo centro de gestión económica, tecnológica y administrativa), considerado como no practicables o verdaderos.

Esto supone, contradictoriamente y como anacronismo ${ }^{24}$, la carencia generalizada desde la institución Universidad de un enfoque distributivo de la gestión del conocimiento -en base al idioma, a los individuos y a sus necesidades y proyecciones humanas- que reconozca, sin tecnicismos administrativos y por tanto basado en un nuevo humanismo, "el lugar central del ser humano en general",, 25 (y en este punto nos apropiamos de las palabras de Bédard), que tenga en cuenta como prioridad cuestiones propias de las particularidades individuales, lo que implicaría que no sólo la comprensión revitalizada de la idea de universidad, sino, de partida, el respeto valorizado de los potenciales de las personas en relación a los modos de actividad respecto a la sociedad y al grupo. Stephen Ball ${ }^{26}$ ya deja ver esta problemática cuando dice, en el marco de Presentación de Michel Foucault, que "las posibilidades de significado y de definición están cubiertas de antemano por la posición social e institucional de quienes hacen uso de ellos. Así los significados no surgen del idioma, sino de las prácticas institucionales, de las relaciones de poder". Lo deja ver en tanto que la gestión discursiva -construcción de subjetividad y de relaciones de poder- que del conocimiento hace la institución Universidad sólo llega a significarse como significado

24 SCHELlen, MAx. "El saber y la cultura". Ediciones elaleph.com. 1999. Max Scheller en su larga conferencia ironiza sobre este anacronismo cuando refiriéndose a la Universidad (Alemana) dice: "tenemos también la institución, bien contraria al espíritu universitario alemán, de las llamadas cátedras de conceptos católicos del mundo, establecidas en Universidades desprovistas de Facultad de Teología católica".

25 Ibíd., p. 74. En "II El lugar del ser humano en el campo de los estudios y de las prácticas administrativas". La concepción humanista de la actividad administrativa que se propone aquí y que consiste en elaborar un enfoque que reconozca, de un lado, el lugar central del ser humano en general y, del otro, tenga en cuenta las particularidades individuales, lo que implica no solamente comprender las características propias de la especie humana sino también respetar y valorizar los potencialidades específicas de las personas, que son la fuente de la fecundidad del grupo.

26 BAll, Stephen J. “Foucault y la educación. Disciplinas y saber" en Presentación de Michel Foucault. Ed. Morata. Madrid, España, 1997. Pág. 6. 
institucional, como régimen de verdad, tal como fue organizado su sentido curricular.

\subsubsection{Los individuos de apoyo enclasados}

"Los discursos no se refieren a objetos; no identifican objetos; los construyen y, al hacerlo, ocultan su propia invención". ${ }^{27}$

Un diploma de licenciatura, un título de especialización en lo que sea, uno de doctorado o de cualquier maestría, lo que hace es legitimar el conocimiento/discurso de sus portadores (de los individuos de apoyo enclasados) pero sobre todo les confiere un lugar -un principio de lugar- en la relación de poder-saber donde ellos han sido investidos de autoridad.

La docencia que permite reproducir un cierto tipo de saber y la respectiva credencialización que lo legitima, tienen su cimiento en una propuesta curricular, que en la gran mayoría de las veces fue diseñada por un grupo de especialistas. Sin embargo esta forma de concebir el diseño de una propuesta curricular no permite comprender ¿por qué se decide seleccionar unos contenidos de aprendizaje en detrimento de otros? Esta y otras preguntas de la misma índole han estado durante mucho tiempo olvidadas en la discusión curricular, por una parte la perspectiva tecnológica las obvia por considerar que su respuesta es eminentemente académica y son productos racionales del diseñador del currículum, mientras que la perspectiva crítica ofrece una línea de discusión que gira alrededor del concepto "determinación curricular" y que propone respuestas que se encuentran fuera del sistema curricular, sea en la esfera política, cultural y/o económica de las sociedades ${ }^{28}$ En términos foucaltianos, se puede contestar a esa pregunta al afirmar que el diseño de una propuesta curricular (producción, regulación, distribución y operación) no es más que un proceso de inclusión/exclusión de conocimientos a partir de un cierto régimen de

$27 \overline{\text { Foucault, Michel. (1974), pág. } 49 .}$

28 Barraza, Ibídem, pág. 3 
verdad y en estos casos, a partir de una política de lo verdadero que tiene sus raíces en las tradiciones que conformaron el método, y por consiguiente el conocimiento, científico durante cinco siglos.

Más allá de este proceso de reproducción y legitimación que realizan las universidades, también es posible identificar otro binomio de funciones como lo serían la investigación y la difusión. La investigación permite producir (producción, distribución y operación) un cierto tipo de conocimiento y de discurso a través de un conjunto de procedimientos, reglas y técnicas que son compartidos por los miembros de una comunidad científica. En ese sentido, el conocimiento y discurso generado bajo ese conjunto de procedimientos pueden ser incorporado al saber verdadero y otorgársele el estatus de conocimiento científico. Esta forma de concebir la investigación se constituye en una relación de poder donde los investigadores son investidos de autoridad para determinar cuando un conocimiento/discurso ha sido elaborado mediante estos procedimientos (regulación, distribución y operación) y por consecuencia puede o no ser considerado como un conocimiento científico (lógica de inclusión/exclusión). Aquellos saberes o conocimientos que no son considerados científicos son identificados por Foucault (2001) como saberes sometidos. A decir, conforman el conjunto de saberes no sometidos aquellos saberes y conocimientos propios de un diseño curricular sin peso efectivo en la calidad proyectual del régimen de verdad. Sin embargo, al margen de la observación foucaultiana nuestra consideración apunta como significativos en la aproximación a un diseño de estrategia curricular (optimo y orientado a la persona, precisamente a esos saberes no sometidos en relación a las necesidades de expresión-cognitivas bien del grupo (múltiples sujetos cognoscentes) o bien de la persona (sujeto cognoscente).

Con necesidades de expresión-cognitivas nos referimos, igualmente, a la necesidad de aproximación, por parte de esos múltiples sujetos cognoscentes, a toda una serie de saberes y modos de prácticas que están descalificados -aquí entran en juego las redes de investigadores, los sistemas nacionales de investigación o simplemente los profesores investigadores se constituyen en los agentes que detentan el poder en este proceso de generación del conocimiento/discurso- como saberes 
no conceptuales, como saberes insuficientemente elaborados: saberes ingenuos, saberes jerárquicamente inferiores, saberes por debajo del nivel de conocimiento o de las nociones de cientificidad exigidos.

Conjunto de necesidades de expresión-cognitivas que al contrario que el conocimiento/discurso -que se genera a través de la investigación en las universidades y tiene en la difusión su medio más efectivo de socialización y vinculación con la comunidad (distribución y operación), pero al ser ese conocimiento/discurso generado bajo la lógica de la inclusión/exclusión su socialización sirve para incrementar su legitimación a través del respaldo institucional que se le otorgaprovienen en sí, y ya, de la socialidad misma de las prácticas bases, de las prácticas de lo común, como su naturaleza de inicio, y que por lo tanto no entienden de política de socialización (de formas vehículos para hacerlo) por cuanto ellas -como necesidad común ya se pretenden socializadas.

\subsubsection{El rombo de Bédard y la praxeología que nos interesa}

En este punto podríamos decir que las cuatro grandes ramas filosóficas o categorías que Bédard anuncia para la descripción del perfil y la especificidad de occidente y su Administración -en nuestro caso entendidas como metodología operativa y herramienta de observación (inductiva y predictiva)-, por ser descripciones en si de esa especificidad y herramienta de reflexión, de búsqueda idea acción, debería permitirnos (aunque de un modo esquemático) extraer un conjunto de perfiles (características fundamentales de la naturaleza humana) posibles de ser articulados, o al menos ser considerados, dentro de toda estrategia curricular propia de occidente, ya no sólo en el ámbito administrativo sino sobre todo en el ámbito de la educación y del conocimiento.

Nuestro perfil de características, propias de la naturaleza humana, o cuyo origen de selección parte de ellas, estarían siempre orientadas al ámbito de aquellas manifestaciones de orden o de producción de carácter simbólico como son, por ejemplo, la enseñanza de la arte 
o de los modos prácticas artísticas, y que en todo caso resaltarían todas aquellas zonas de interés cognitivo en relación al conjunto de necesidades de expresión-cognitivas del sujeto cualquiera occidental, bien pocos tratados en los diseños curriculares propios de la enseñanza del arte en la universidad. En este sentido a partir del modelo del rombo de Bédard extraeremos aquellos perfiles que consideramos pertinentes atender, de tal modo que la reproducción de sus esquemas obedece sólo a fines estrictamente orientativos:

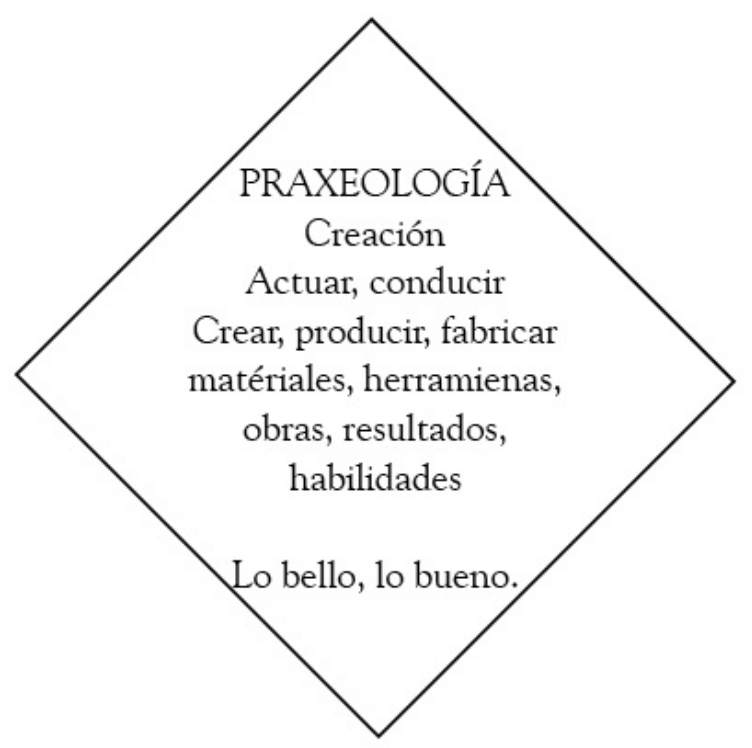

Figura 34: La praxeología de R. Bédard

De las cuatro partes de su modelo de observación nos interesa sobre todo la praxeología porque tal como Bédard ${ }^{29}$ lo describe (no de forma directa porque lo hace a través de Sylvain Auroux, es un (esquema ${ }^{30}$ )

29 Cuando cita a AGUIRRE ORAÁ, José María. "Praxis". AUROUX. Sylvain (dir.) op. cit. Vol. 2, p:2022.

30 Usamos esquema o diagrama en el sentido de su carácter de ensayo, y en consecuencia, pensado en un cierto estado de provisionalidad susceptible, como es evidente, de cambios a todos los niveles. Recuerdese que básicamente hacemos una extrapolación 
"campo en el que se despliega toda la actividad humana31"; a decir, donde encuentra su revalorización gnoseológica todo aquello que propiamente rodea los modos de prácticas individuales (la praxeología también lo es y de igual manera se ve afectada) fundamentadas por un lado en "los criterios de validez que orientan los procesos y los métodos -cuya base y surgimiento hemos de buscarlos en la epistemología-, y por otro, en "los valores sociales individuales y culturales (que surgen de la axiología) que circunscriben la elección y que apoyan las preferencias individuales y colectivas", y ambos, asentados entonces en el substrato de la ontología, como base que "comprende los paradigmas fundadores y que sirven de matriz a las diferentes actividades humanas".

Si bien Bédard utiliza el término praxeología en el sentido del englobamiento de todos los aspectos de la actividad humana y no sólo la acción y sus diferentes realidades particulares, nosotros proponemos el término en el sentido del nombramiento didáctico (por lo tanto curricular) de las particularidades tanto de la actividad humana como de la acción, pero con la determinación de que es pensada como posibilidad articular, que sea recuperada su operatividad teorética como base sensible en el conformado curricular -entonces a partir del propio juego de nociones de la extensión praxeológica- de un conjunto o bloques de materias orientadas a explicar la consistencia teórica de toda actividad o acción humana -también las orientadas hacia el conocimiento-, como por ejemplo, y teniendo como marco el carácter general y de punto de vista humanista (centrado en la persona y su particularidad) de Bédard cuando dice que "la praxeología contiene una base teórica que la da los fundamentos conceptuales propios", un bloque correspondiente a la praxis y la poiesis que debería corresponder y poder explicar: 1) la diferenciación

de práctica de su modelo comparativo y de observación, para de ese modo sumergirnos, como posibilidad de teorización, en el lugar de las vivencias propias de los modos de prácticas relacionados con el arte.

31 Ibíd., p. 78. Esta cita es una frase atribuida al filosofo español José María Aguirre Oraá que Sylvain Auroux emplea en uno de sus Volúmenes (2), sin que nos quede claro el texto de referencia al que se hace alusión con "Praxis", quedando expresado de la siguiente forma: AGUIRRE ORAÁ, José María. "Praxis". AUROUX. Sylvain (dir.) op. cit. Vol. 2, p:2022. 
de la conducta humana, y 2) la actividades de creación, de producción y de fabricación.

Un segundo bloque que debería poder explicar "las actitudes" (en los planos cognitivo, afectivo y comportamentales);

Un tercer bloque orientado a explicar "las prácticas, los métodos de trabajo y los procedimientos";

Un cuarto bloque que explicaría las herramientas, los materiales, las técnicas y la tecnología.

Un quinto bloque temático que ha de explicar "las palabras y los escritos".

Y un último bloque que debería poder explicar la consistencia teórica de obra, del producto, y del resultado.

"La praxeología está constituida por la realidad cotidiana fenomenológica, el mundo de los acontecimientos, los hechos y los actos de las personas que hacen su práctica en el campo en cuestión y que ejercen una actividad especializada. Esta base empirica se caracteriza por lo particular, lo individual y lo contingente. Ella es el lugar por excelencia de la vivencia, del presente, de lo subjetivo, de la sensibilidad, de lo existencial, "del gesto y de la palabra". La praxeología es el dominio propio de la estética, del juicio, del arte, de la tecnología y de la técnica, de la realidad material en todas sus dimensiones."

Lo que fundamentalmente nos interesa en relación al problema de la enseñanza del arte, es el hecho de que las materias propias de la praxeología al estar constituidas por la realidad cotidiana (realidad fenomenológica) y el mundo de los acontecimientos, los hechos y los actos de las personas, caracterizan -en tanto que ocupan un lugar prioritario como ordenaciones gnoseológicas-, lo particular, lo individual y lo contingente, al tiempo que de ellos se reconoce la condición de ser lugares [de sensibilidad: sentido/ sentimiento] "por excelencia de las vivencias, del presente, de lo subjetivo, de la sensibilidad, de lo existencial, del gesto y de la palabra", ser "dominio propio de la estética, del juicio, del arte, de la tecnología y de la técnica"32 por tanto reconocimiento, 
en términos muy próximos a los intereses y también prioridades de los modos de hacer propios del arte, cuya expresión en el tramo formativo de la idea de idea de proyecto de obra como "objeto de saber" en relación al proyecto artístico fluye a niveles o en la frecuencia de lo cognitivo, la bondad, el placer, el dolor y la discontinuidad.

Y para ello, como expresa Renée Bédard y que nosotros sugerimos como en su posibilidad curricular anclados sobre los tres campos

a. la epistemología, como "el lugar donde se debate de manera particular y precisa el problema filosófico de la verdad; el lugar donde ese problema es proyectado, circunscrito, determinado, efectuado"33,

b. la axiología, que "designa el campo de los valores individuales y colectivos, es decir los valores morales y culturales, así como el enunciado de los principios que determinan las costumbres" $34, \mathrm{y}$

c. la ontología, que para la persona determinaría "su manera de habitar lo real, de orientarse en medio de las cosas y de encontrar una salida en la búsqueda de sí"35

que completan el rombo, "como objeto de reflexión y de investigación, la praxeología suministra una información de tipo fenomenológico, es decir que el conocimiento que ella procura está ligado a la sensibilidad (los cinco sentidos y los sentimientos)." 36

La perspectiva de análisis, de proyección y de contribución del arte se mide de acuerdo a sus productos finales

Como apuntábamos en nuestro PAISAJE TEóRICo, no hay duda de que aún la perspectiva de análisis, de proyección y de contribución del arte se mide - tal vez, se clasifica-, "de acuerdo a sus productos finales: cuadros, obras de teatro, sinfonías o lo que sea». Como tampoco cabe

33 Ibíd., pág. 79.

34 Ibíd., pág. 81.

35 Dardel, Eric, Le mythique en Diogène, Paris, 1954. vol. 7, p.50. En Bédard, Renée. Los fundamentos del pensamiento y las Prácticas Administrativas: El rombo y las cuatro dimensiones filosóficas. pag. 83. Traducción del profesor Rodrigo Muñoz G. ADMinister - Universidad EAFIT. Medellín, Número 3. Junio - Diciembre 2003.

36 Ibídem, pág. 78-79 
duda de que las rutinas y esfuerzos clasificatorios continúan, del mismo modo que el inventario de síntomas superficiales para el análisis de la acción contributiva del arte sigue creciendo; crecimiento imparable y deformador que sigue teniendo lugar por la simple razón de que en la constitución misma del síntoma, o del conjunto de ellos, no entra en juego, para nada -puesto no se nos educa en la multiplicidad de ello-, la consideración de los procesos creativos, los sistemas básicos de análisis o de los modos perceptivos que sirven de vehículos o de tensores formativos de los productos artísticos finales. En ese sentido, nuestra inicial sospecha respecto al papel de contención que dichos modos de clasificación juegan en las estrategias de planificación de los modelos de enseñanza del arte, y el papel de distanciamiento real en relación a la posibilidad de contribuir al diseño de planes de estudios generales que influyan directamente en la enseñanza de otros campos de producción como el de la enseñanza de la ciencia, o de la filosofía, deduce no sólo una cierta ansiedad en torno a la cuestión formativa de las cosas como tal [la cosa parece que siempre ha sido así, sin proceso alguno], sino, en su caso, algo que oscila perversamente entre los márgenes del analfabetismo disciplinar y el de la fantasía del poder: la cosa debe seguir pareciendo que siempre ha sido así [tal cual], o, en el peor de los casos, su radio de acción reflexiva o zona de influencia crítica, ha de permanecer al margen del modo mismo de su clasificación.

Respecto a la segunda de nuestras sospechas, queda claro que el reducto del arte es, sin duda, parte y proyección de la fantasía del poder: es por ello, en tanto que diseño de andadura y gestión de los límites del poder, un modelo de clasificación y de un modelo de gestión disciplinar todavía de naturaleza reaccionaria en tanto no se le entiende ni se le explica como un modo de hacer cuya especificidad (de base necesariamente gnoseológica) es siempre variable en relación a una cadena circunstancial de imponderable socio-económicos.

Por último en relación a la tercera de nuestra sospechas, los modelos y configuraciones actuales de la enseñanza del arte albergan en su fondo profundo un, más que perverso pervertido, espíritu burgués cuyo latido se proyecta, y no de otra manera, como amenaza de fragmentación contrapuesta al incremento de las capacidades de obrar y comprender 
que se desprenden del desarrollo autónomo de otra sensibilidad o facultad de enseñanza, ya no sólo del arte, sino también, del desarrollo autónomo de otras formaciones de enseñanza en general.

La rapidez con la que se dejan atrás los debates de cuestiones de enorme complejidad es proporcional a la rapidez con la que se dejan atrás las convicciones

Hoy, en este estado de crisis generalizada, es evidente que la rapidez con la que se dejan atrás los debates de cuestiones de enorme complejidad es proporcional a la rapidez con la que se dejan atrás, sin sonrojo alguno, las convicciones como un innegable e intenso momento de verdad. El debate que sobre la Universidad en este tiempo nos urge -sobre la naturaleza de hoy de la universidad-, parece, sin embargo, que para nada ha comenzado, al tiempo que el ratio de convicciones que debería sustentarlo se vislumbra tambaleante, distraído y quizás, tal vez, abandonado. A decir, tal abandono no denota un dejar ahí o por ahí la cuestión del debate, sino un deteriorarse constante de la atención, un deteriorarse la posibilidad de la interpolación sobre el núcleo pertinente del mismo, sobre el límite localizado de eso mucho que nos afecta, el requisito mínimo de responsabilidad. Manifestamos nuestra objeción a un cierto "estar fuera de lugar y de forma" del debate como posibilidad de la relación. Esto es, dicho de otro modo, un visible desfase escópico entre las fuerzas de análisis, los potenciales prácticos y las naturalezas concerniente a los ámbitos. Pero es que ¿acaso la realidad formada organizacionalmente, en la que se asientan los sistemas parciales -especificados funcionalmente- de una sociedad altamente diferenciada, no se basa sino en otras premisas, en estados previos de cosas? Nuestra insinuación, sin duda, apunta hacia una cierta necesidad de distinción entre las formas de abordaje de la cuestión, las especificaciones funcionales de los dos ámbitos de la relación [ya sea éticas, políticas, morales, económicas, artísticas, retóricas, etc.], que en su lugar no sólo darían sustanciosas respuestas en relación al conocimiento del tema, sino sobre todo, inscribirían la cristalización de las preguntas 
pertinentes entorno también a la especificidad del discurso -basado el primero en la idea de universidad y el segundo en la idea de práctica artística- de las comunidades protagonistas de la localizada problematicidad; esto es: se haría visible el plano discursivo que conduce la cuestión debatida, o bien como un plano moral o bien como un plano ético.

Como ya antes hemos apuntado, la cuestión pasaría por aclarar -de principio- la naturaleza y dimensión de la oposición existente entre modelos discursivos: uno, el de las prácticas artísticas (y no el del arte, que ya es otra cosa), y el otro, el de la universidad; oposición en la que subyace paradójicamente la contradicción de que ambos lo hacen anclados en una cierta postura de dominio, de ser algo (su Idea de...), como es lógico, con una especificidad diferenciada. La cuestión de la relación práctica artística-universidad no es un problema viejo, como no lo es tampoco la universidad, y ni siquiera lo es fundamental por cuanto es artificial: es un problema de políticas de relación. A saber, es un problema sobre la relación y no de la relación, que evidentemente ha de ser explicado aunque no tanto desde la proyección conveniente de las prácticas artísticas con vocación universitaria como sí desde los presupuestos tendentes a su exclusión. En este paso cabe pensar en una unidad, o en la posibilidad de que lo sean, ante la intuición de que no es así. No son y no serán una unidad de relación aunque si una unidad conveniente siempre y cuando, para saber que ha ocurrido en ellas, en el análisis se las separe. Así cada una mostrará necesariamente su pensamiento; la primera, la idea de práctica artística que, a su vez, explicaría toda su tradición y la relación afirmativa con los campos disciplinares humanísticos, además de su proyección apolítica de cara al estado; la segunda, la universidad, exhibirá aquello que ata su idea a su concepto de Universidad y explicará las características de la tradición universitaria, haciendo comprensible su relación afirmativa con la ciencia, el conocimiento, la sociedad y el estado. En ese sentido la forma de mostrar las fuentes de tensión natural y sus funciones en el plano de aportación a la cultura, tanto de un ámbito como del otro, ganarían la nitidez necesaria como para, en el haber sido localizadas, visibilizar las nuevas formar de tratamiento del mundo de vida, en 
principio, y de su producción tanto de simbolicidad como de artefactos técnicos, después, a modo por tanto de baremo diferenciador con aquello que ya hace lugar, bien como instituido, bien como reconocido o bien, como institucionalmente legitimado. En definitiva la idea que aquí cobra cuerpo es la de considerar las definiciones de los ámbitos de la relación en términos de cada naturaleza en cuestión, para poder de esa forma dilucidar la relacionabilidad y las tensiones o no, de las dos formas de gestionar la representación, y así mismo, la investigación, el conocimiento y la cultura.

Por último, la universidad en medio de la cuestión de las contradicciones de tipo culturales ha de ser tratada desde dos posibles ángulos de mira: El primero ha de ser desde el enfoque de la universidad en su condición institucional, y por tanto, dependiente de un gran número de poderes, y así, como correa de transmisión tanto de sus aspiraciones como de sus crisis. El segundo ha de ser desde el enfoque del estado de la universidad como una consecuencia; o sea, la universidad en su condición de institución, y por tanto como poder resistente, protector y subsanador de sus propios errores, y en ese sentido, como entidad afectada por su propio contexto: a decir, en uno de los supuestos, de manera directa, y en otro, de forma indirecta. Fiel, por tanto, a nuestro ensayo Cultura_responsabilidad_universidad, si revisáramos la idea misma de universidad -entonces asumiendo el conjunto de estas premisas y desde la conciencia de nuestra responsabilidad ante el futuro-, la tarea de la universidad y su devenir como institución habría de enmarcarse en un espacio móvil, de actividad liminar entre múltiples conflictos: En consecuencia, la universidad actuaría desde el conflicto y en el lugar del conflicto -a decir, no hay idea de universidad sin cuestionamiento, sin vocación de cambio y de transformación.

Lo que los elementos discursivos colman es todo aquello, limitado por la habituales formas de análisis

En occidente sólo el empuje de una gran presión social (distorsionadora) es lo que ha hecho que lleguemos a considerar las 
técnicas de leer, escribir y contar, como útiles para sobrevivir. Al margen de ellas, el propio sujeto occidental, se encuentra sumido en la más profundas de las ignorancias, respecto a su propio paisaje y eje cultural. La escritura y lectura de la palabra sólo parecen servir para enumerar o contar la cosa a la que representa, sin embargo, por sí misma parece no poder hacer ver la cosa tal cual. En cualquier caso la palabra escrita, leída y contada necesita de algo más para poder abrirse al ver de la cosa, necesita un complemento técnico (externo a ella) que la acoja: así, en relación a una técnica y según una estrategia, es que se vuelve útil conforme un fin.

En relación a aquello que la metodología de detección de los elementos discursivos -como dotación de un principio de análisis- pretendería resolver, habría de estar siempre circunscrito a aquello relacionado con la idea de idea de proyecto de obra que desde los ámbitos de la teoría y de la educación de las prácticas visuales sólo ha podido ser mostrado como descripción, y por tanto, a través de las construcciones representacionales de imágenes -a modo de técnica de disfraz o de visión selectiva de procesos cognitivos o de tamización de significaciones- ocupadas de explicar el comportamiento esencial de cosas que tal vez no admiten dicha estructura de representacionalidad decodificadora. Lo que los elementos discursivos colman es todo aquello, limitado en el análisis, de lo que la academia (el ejercicio como tal) no ha podido extraer ni su voz y ni su naturaleza, por haberse centrado exclusivamente en los significantes entonces vaciados, en el plano solo de la expresión (de la forma): todo aquello que necesariamente hay que pensar y todo aquello que necesariamente hay que saber como condición indispensable para la constitución de la idea, aunque añadiendo además, en tanto que escritura de lo biográfico que debe vivirse por ser una imprescindible condición (la de la experiencia) de cara al potenciado de las unidades básicas de significación. 

Parte V

APÉNDICE 



\section{ESCRIBIR LOS MODOS DE PRÁCTICAS}

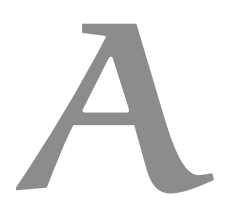

"Cuando los objetos artísticos se separan tanto de las condiciones que los originan, como de su operación en la experiencia, se levanta un muro a su alrededor que vuelve opaca su significación general, de la cual trata la teoría estética. EI arte se remite a un reino separado, que aparece por completo desvinculado de los materiales y aspiraciones de todas las otras formas del esfuerzo humano, de sus padecimientos y logros. En esta tesitura, se impone una primera tarea para el que pretende escribir sobre la filosofía de las bellas artes. Esta tarea consiste en restaurar la continuidad entre las formas refinadas e intensas de la experiencia que son las obras de arte, y los acontecimientos, hechos y sufrimientos diarios, que se reconocen universalmente como constitutivos de la experiencia. Las cimas de las montañas no flotan sin apoyo; ni siquiera descansan sobre la tierra, sino que son la tierra en una de sus operaciones manifiestas. Es asunto de los que están dedicados a la teoría de la tierra, geógrafos y geólogos, hacer este hecho evidente con sus diferentes implicaciones. EI teórico que quiere tratar filosóficamente de las bellas artes tiene que cumplir una tarea semejante.

John Dewey ${ }^{1}$

1 DEWEY, JOHN. El arte como experiencia. Colección Paidós Estética. Ediciones Paidós, 2008. Traduccíón y prólogo de Jordi Claramonte. 


\section{A.I PROYECTO NADA}

La retícula que trama este proyecto se llevó a cabo en la galería Cabildo de Santiago de Cuba en 1988, pensamos que sería necesario -antes de abordar la propuesta- situar someramente algunas cuestiones, por ejemplo, que es un «tipo de práctica alternativa» dentro de proyectos de inserción socio-cultural. El espacio de la galería es un lugar donde se realizan conferencias, performances que día a día van afectando a las obras que en un principio eran soportes blancos -cuadros vacíos. La intervención en las superficies con inclusión de gestos, signos o incluso la inserción de objetos por parte de los espectadores era el proceso que construía la obra. Por esta modificación continua, la difusión crítica y social que se transmitía a los medios artísticos no respondía por lo tanto a lo que en realidad reflejaba la obra en ese momento.

(1) NADA. NEGATIVA AL ESQUEMA MEDIbLE. DAR TACITAMENTE OTRA POSIBILIDAD. CONVENCIÓN TRUNCA. Es una posibilidad operativa que se diseña como necesidad de penetrar (HACIENDO) un conjunto social desde perspectivas sociológicas y emancipar o curar las zonas enfermas. Experiencia practicable sobre un proceso infinible controlado. Espacio divergente. Espacio real, supuesto, determinado por la reciprocidad temporal entre el cuerpo interior y el cuerpo exterior del creador, las otras partes y el contexto (tránsito contrario, sentido inverso, lógica supuesta). Descubrimiento público de la doble actividad del creador, del HACEDOR. La posibilidad objetiva de una reflexión a cerca de la doble práctica del «espectador-obra»; resultado en dos sentidos o líneas, el roce erótico entre lo esquemático y la praxis temporal. VERDAD EVOLUTIVA CONVERTIDA EN SU PROPIA NEGACIÓN. PROCESO VISTO EN EL PENSAMIENTO, VISIÓN SUPERADA=NEGADA EN SU PROPIA 
EVOLUTIVIDAD. NEGATIVA DE LA LEGITIMA VIRTUALIDAD DEL HECHO OCURRIDO=RIDICULIZACIÓN CONSCIENTE DE LA VERDAD POETICA $(i ?)$ Práctica de la infidelidad poética del saber con el nuevo saber; arribo a la «totalidad expresiva» (entrega total a la aventura, futuro del saber poético).

(2) Posible. Zona posible (vulnerable) en un conjunto social: la crítica ( $i$ ) -Nuestra zona la critica- cualquier grupo o subgrupo marginalidad/no marginalidad- un posible. Todo grupo social posee una zona «enfermiza». La práctica de «NADA» se conduce sobre la base de la «detección», publicación y superación de la zona enferma. El proyecto va unidamente hacia dos puntos del amor social de lo humano: hacia lo artístico y a la sabiduría social. LOS LÍMITES DE SU SABER (límite infinito-posible, límite finito-imposible). «SUPERACIÓN DE LA ACCIÓN DE «CREAR» Y PRIVILEGIO DE LA VOLUNTAD DE «HACER»...» Saber. Saber oficial, contrario al saber general - Esquema estándar de apreciación.

(3) Operatividad. El diseño constructivo de «NADA» está determinado por la definición de los límites y modelos encontrados en el grupo donde se opera. Tal definición decide el tipo de obra y las formas de la práctica. CRITICA CENTRALIZADA = ARGUMENTACIÓN CRÍTICA PREFIJADA = ENFOQUE ÚNICAMENTE POLÍtICO. RIGIDEZ DEL CRITERIO = LÍMITE FUNCIONAL DEL SABER GENERALIZADO. NO FLEXIBILIDAD EN LA VARIEDAD DE LOS ÁNGULOS CRÍTICOS.

(4) Respuesta práctica (Presupuesto como negativa): «NADA». Blanco estratégico y erótico de franco tirador (FRANCO «HACEDOR») hacia la crítica como generalidad. Público en su relación indirecta (involucra a un grupo de artistas). En el recorrido evolutivo de la experiencia se opera desde la «extracción-abstracción». Los modelos generalizados, los esquemas y las problemáticas de índole socio-artísticas son 
separados (reproducidos) de su contexto y mostrados a sus portadores. SIMULACRO DE COQUETEO CONCEPTUAL = ACERCAMIENTO ENMASCARADO, MANIPULACIÓN DE SU PROPIA RETÓRICA. ACCIÓN OTRA = GOCE ESTÉTICO OTRo, juego artístico otro (asimilado por el resultado de la acción virtual) generado por el «hecho otro». Hecho real que marca los lineamientos, la infinitud, los límites; hecho oculto, no la virtualidad impresionista. Oposición a la liberalidad de las afirmaciones casuales. Estrategia. REITERACIÓN DE LA CONVENCIÓN $=$ A SU ROMPIMIENTO. Blanco, blanco, blanco, blanco, blanco = línea blanca por sucesión del blanco. Definición de la linealidad que no es. Crecimiento paralelo; definición por oposición. Verdad límite; conversión de la verdad límite en su negativa poética (i?).

(5) Presencia perspectiva del artista (elaboración diaria como gesto de diferenciación cualitativa). Constancia prudencial controlada. Del gesto abstracto a la imagen referencial (simbólica) reconocible. Recuperación transitoria de la imagen histórica. Reencuentro con la convención = Alejamiento dinámico de la misma = Reafirmación de ella como saber y negación del sentido esquemático. Rompimiento del modelo = Apertura a un nuevo modelo (abierto), reflexivo, actual; aprehensión práctica de lo reflexivo, dinámica del nuevo saber $=$ Comprensión por contemporaneidad. Autodestrucción. Tramo recorrido, truncado por la propia expectativa. Destrucción total de la eventualidad (salto cualitativo). Diferenciación dialógica el fenómeno artístico. Dos experiencias $=$ espiritualidad y práctica $=$ Hacer. 


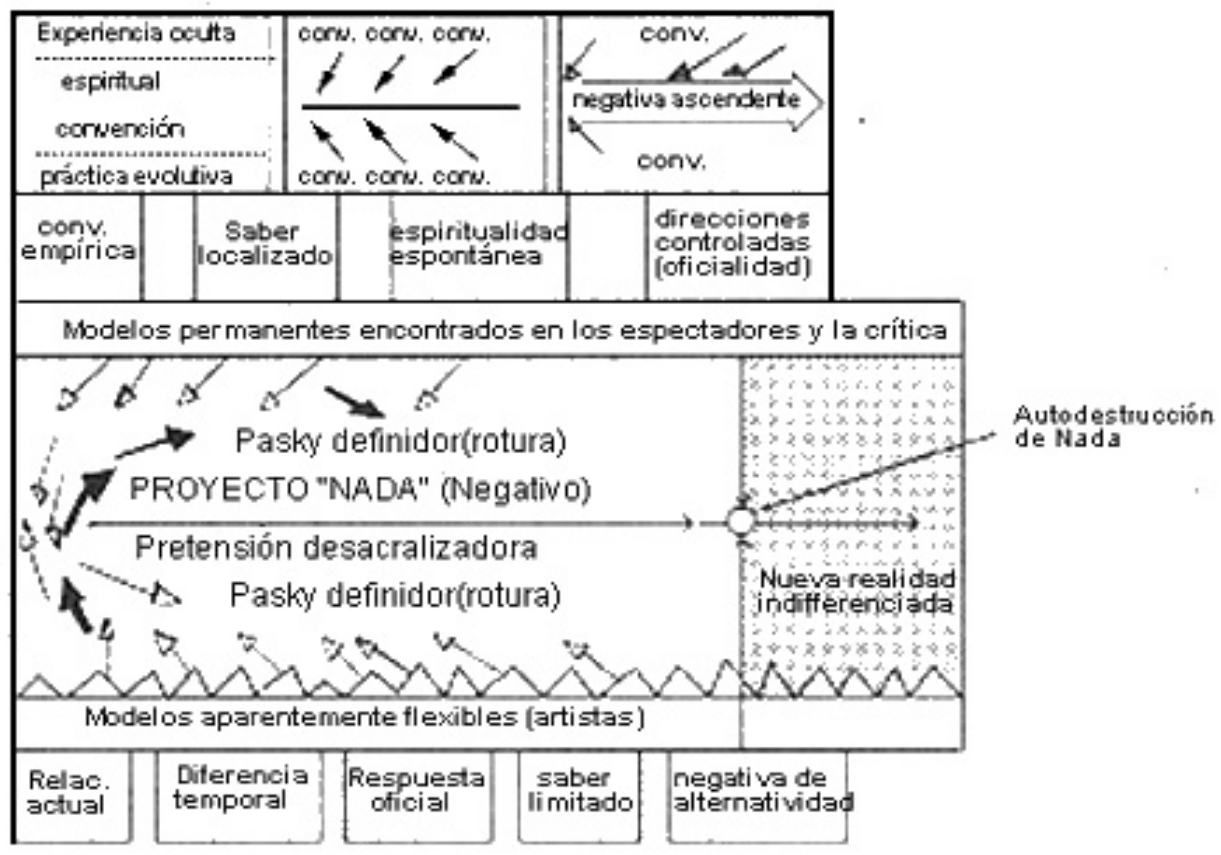

Figura 35: Descripción del comportamiento del proyecto 


\section{A.2 SOBRE CARIBE INEXPLORADO, DE BELKIS RAMÍREZ}

"Se trataría, tal vez, de provocar, más que un discurso, un sentido; (...) no descubrirlo, restaurarlo ni reemplearlo, sino... producirlo, mediante una nueva maquinaria". Ivan de la Nuez Sin equivoco alguno para América Latina y el Caribe las décadas de los 80 y 90 fueron excepcionalmente importantes en la proyección internacional de las producciones y pensamiento, en cuanto al arte, que allí tuvo lugar. En ello, como una vertiente palpable de las investigaciones llevadas a cabo por el Centro Wifredo Lam, ha jugado un papel de primera importancia la Bienal de la Habana en sus sucesivas ediciones; de cuya estrategia, por más cumplida, de constituir un espacio propicio para el intercambio y la discusión de problemas que atañen al arte contemporáneo internacional, y sobre todo, a las prácticas dadas al respecto en los países del Tercer mundo, ha surgido - más que visible, práctico-, un foro de plural resistencia en el concierto universal contemporáneo, sin que esto signifique, en modo alguno, una vehemente y apasionada mirada del ombligo, sino más bien, el reconocimiento pleno de la interculturalidad formativa, flujo y reflujo, intercambiabilidad, sincretización y mestizaje - especialmente en Latinoamérica- de estas nuevas culturas, y de su proyección y vocación universalista: De estas nuevas máquinas, que no sólo como puntos de llegada, sino también como puntos de partida, empiezan, con claras evidencias, a producir sentidos. Muy próxima al marco providencial de las sucesivas ediciones de la Bienal de la Habana - y paralelamente a importantes producciones, contextualmente renovadoras, como las de Tony Capellan (instalaciones y ambientes, sustentados sobre la base de una antropología de lo popular que deviene en denuncia); las de Alonso Cuevas (de un lirismo, cuasi-neoprimitivo, que reelabora y se aproxima al grafismo dado por acumulación espontánea en los espacios cerrados de función pública); las de Antonio Guadalupe, y sus recreaciones sobre la memoria y la fauna; y las instalaciones de Marcos Lora Read (una arqueología reflexiva sobre la historia dominicana y la «conquista»)-, Belkis Ramírez comienza a hacer sus incisiones en el panorama plástico dominicano y regional, en principio puramente gráficas (pues recuerdo 
sus obras expuestas en la Habana, 1986, y en el Festival de la Cultura Caribeña, Santiago de Cuba, 1991), y luego, sobre variantes más complejas, como las expuestas en CARIBE INEXPLORADO, que transcurren en torno a una cosmovisión ambiental, remitente por sí a escudriñadas reelaboraciones - mas el amor furtivo es la obcecación familiar ante el ismo- de haceres primarios y, por históricos, próximos, y por aproximados, notorios de las maneras «instalacionísticas», que apuran su marcha, divididas ya en visibles e invisibles, por estar a punto de transformarse en "cosas» y de sepultar sus iniciales misterios bajo esas cosas que han de ser. En la obra de Belkis, digamos que en la zona que podría considerarse como gráfica — pues esa zona se articula de dos maneras: una que literalmente se ocupa del grabado y todo su procesamiento, y otra que complementa un universo dimensionalmente más amplio y provocativo- habitan almas, espiritualidades que fluyen en torno al hombre: diría que máscaras que solapan verdades y representan conceptos. En la primera manera de utilización de lo gráfico, del grabado y la totalidad de los procesos que lo dignifican, la xilografía fulcraliza el modo básico de la orientación discursiva, y del contar fantasioso, dado a veces como reiteración dialógica de un texto sobre (y con) la mujer: de su problema histórico. Ahora bien, texto esta aquí usado en la concepción deleuciana; por tanto, va entre paréntesis. Textos graficados e interioridades reclamadas, advenidos como la vigilia para que los abandonemos — pues que la revolución de ellas está en marcha-, como abandonamos el sueño precipitados hacia ella. Por otro lado, en la segunda manera, el grabado «inicial e inconcluso» - para Belkis Ramírez, la matriz que actúa y precisa sentidos-deviene en un vehículo de contrastación: en pared, silueta, o cortinaje de fondo, que al decir su palabra, narrar o presentarse mágica, entonces niega, para así hacer una reafirmación sucesiva del cuerpo, ambiente o fisicalidad, que la complementa, desune y une; ejerciendo de centro que, por virtud, atrae todo lo que en torno él aparenta comportarse disperso, y a cada uno de los elementos que configuran un ambiente, o si se quiere, la instalación. En "DE LA MISMA MANERA, 1994", un tirachinas gigante (del lado de allá, cruzado el charco, un tirapiedras, sin más), cuya base es un enorme cúmulo de seborucos —o lagrimas de San Pedro, como diríamos 
en Cuba-, evoca la infancia pasada o quizá cualquier travesura de barrio, y al barrio, como tal, y a sus gestes; pero también es evocativo de un Pop Art trastocado y visto a destiempo, y en consecuencia, el gigantismo plástico de los 50 y 6o, que hace convivir con un panel de «matrices» que aluden rostros, tal ves, familiares, tal ves, máscaras de personajes conocidos, o bien de sus espíritus, que para nada faltan a la solides de la estructura que se le contrapone. Sin embargo, en «LA MESA ESTA SERVIDA (2), 1999", ocurre lo contrario, son los paneles retratos los que crecen, y los elementos de significación (el/los taburete(s): mueblejoya del ingenio y humildad campesina), esos añadidos objetuales para crear o recrear el ambiente final, los que decrecen, marcando un ritmo definitivo que da unidad a la totalidad del conjunto exhibido: una impronta no desdice a la otra. El CARIBE INEXPLORADO, de Belkis Ramírez, es una invitación-ensayo para que ojeemos algo más de lo que ocurre y se piensa del otro lado del «charco», en su Santo Domingo natal: del transcurso y discurso, y del pueblo y sus gentes, que, a pesar de las distancias, da igual poéticas, que físicas o mediáticas, viven. 


\section{A.3 ENTRE FRANJAS BLANCAS}

...En el indicador del paso de peatones apareció la silueta del hombre verde. La gente empezó a cruzar la calle pisando las franjas blancas pintadas en la capa negra del asfalto, nada hay que se parezca menos a la cebra, pero así llaman a este paso... ${ }^{2}$ Ella y yo, también dispuestos a recorrer el trayecto hasta la otra acera de la avenida, nos tomamos de la mano y juntos pisamos la primera franja. En la acera de enfrente sucedió casi lo mismo. Los peatones, lanzados a toda prisa a conquistar el otro lado de la calle, llevaban los ojos puestos en el semáforo. De ser un par de ejércitos a combatir, el encontronazo sería terrible. La primera olas de apresurados, fue seguida por un grupo de personas vestidas casi igual. Tanta uniformidad y aparatos de fotografía, evidenciaba que no eran de muy cerca. Dice Julio Cano Lasso que la ciudad no es simplemente una suma de edificios, comentó ella, mientras miraba inquieta los enormes edificios que, de un lado y de otro, bordeaban la amplia avenida, ¡Claro que es mucho más! Es un cosmos arquitectónico de orden superior, Puede que sí, Digo.. que un juego de interrelaciones históricas... y tal vez, topográficas..., Esta ciudad, ¿la conocías?, le pregunte un tanto distraído. Sí, pero no me refiero a ésta ni a ninguna otra, sino a la idea de ciudad: a ese puzzle abierto, dinámico y casi caótico, en el que es posible encontrar innumerables rastros que podrían llevarnos desde su fundación hasta las actuales proyecciones de la comunidad, Pero ¿te gusta?, ¡Tanto, lo que se ha llevado a buen término, lo destruido o restaurado, como lo proyectado y no construido, forman parte de la idea de ciudad que tengo!, me espetó con autoridad al tiempo que atravesábamos la segunda y tercera franja, en las que sinceramente yo había puesto toda mi atención. El grupo de personas vestidas casi igual, resultó ser de turistas asiáticos. Desordenadas y presurosas, las gentes cruzaban unas entre otras, cual un hormiguero. La primera franja del paso peatonal es una matriz que luego se repite hasta completar el paso de cebra, dije, movido por la curiosidad y la distracción que ello me suponía, Su sucesión forma también un puzzle ordenado y

2 SARAMAGO, J., Ensayo sobre la ceguera. Ed. Alfaguara, 1998, pág. 9 
referencial, Es muy grande... y caótica, ¿Grande y caótica, con tan sólo dos metros por cuarenta centímetros?, Sí, aun maquetada, es caótica, Lo caótico no se percibe por ninguna parte, pero sí, que cada una de ellas es por igual un fragmento de la historia de este lugar... no como memoria, sino como realidades discontinuas y en transformación. Oiga, por favor, ¿Qué autobús podría tomar para ir hasta San Isidro?, pregunto, a toda prisa, una mujer de vestido oscuro y unas gafas enormes, Lo siento, no lo sé, dije, pero ya había desaparecido, sabe dios en que dirección. Apilado, el numeroso grupo de turistas asiáticos, se habían detenido en la medianera, y ajenos al ajetreo estresante de los capitalinos, comenzaron a disparar sus cámaras fotográficas. Por un momento se ilumino la avenida. La hilera de coches fue creciendo en una y otra dirección. Mientras tanto, volví a centrar la mirada en las franjas. La altura, exceptuando las imitaciones lihgt del estilo americano, es la justa, De altura nada, para mí son como seres en una segunda dimensión, Es muy lógico... desde arriba todo se ve aplanado y extendido... preso de la superficie en la que está enclavado... como una imagen, ¡Una imagen, es!, Sí, pero compleja, ¡Complejo, lo es todo!, Sin dudas, lo sé, De hacer desaparecer los edificios y monumentos, todas esas marcas formarían una figura gigantesca... un complicado dibujo sobre el pavimento oscuro, Pero, ¿qué dices? ¿Te interesa la ciudad en cuestión?, No, de ninguna manera. Sólo me interesa el paso de cebra. Digamos, que su continuidad... la temporalidad de su uso... lo sucesivo... su carácter como lenguaje, iporque eso sí, es un lenguaje! ¿no? De repente, se escuchó, no muy lejos, el sonido de una sirena que se abría paso entre los coches. Los cláxones sonaron frenéticamente. Era una ambulancia guiada por una de las motos de la policía. El parpadeo de la luz anaranjada se mezcló con el intenso blanco de los flashes de los turistas asiáticos, que no se perdían una. Ante la curiosa mirada de todos pasaron una y otra, y solo el sonido de la sirena ganó en protagonismo. Como casi siempre, nos quedamos sumidos en la incertidumbre de no saber si iba en busca o venia ya de vuelta con algún enfermo de muy seria gravedad. ¡No! No es un lenguaje ni un sistema de comunicación, sino una ordenación simbólica que refiere y regula las conductas, ¡Que prohibe! Sí, más o menos así, aunque, lo de que prohibe lo has dicho 
tu, Regular y prohibir es casi lo mismo... con la sola diferencia de que la primera politiza y la segunda radicaliza, ¡Ni las marcas viales, ni la ciudad, forman parte de un lenguaje! La ciudad es, en todo caso, un archivo que nos habla de sí mismo. Yo, particularmente, la identifico con la escritura, Entonces, con el lenguaje, ¿o no?, Pues, ¡no!, Muy bien, muy bien, dejémoslo ahí... Pero, por otro lado... ¿sirven como referencias que te hablan o remiten a alguna experiencia temporal?, ¡Sí!, claro está. En las ciudades se condensa el tiempo y los hechos: lo que está ahí y quienes han estado, Quieres decir, que nos remiten a su localización inmediata o temporalidad anterior, ¡Sí!, Así mismo es. Sin embargo, los pasos de peatones no recogen ni pueden hablar de la arquitectura construida o de la proyectada y no construida. Los pasos de cebras que rondan la Puertas de Alcalá, de ninguna manera podrían contarnos o mostrarnos por qué se levantó esta en sustitución de otra, o que Felipe III la mandó levantar con motivo de la llegada a Madrid de doña Margarita de Austria; ni un proyecto como el de aquel arquitecto que, a través de un complicado sistema de esclusas que entroncaban con el Tajo, intentaba conectar la capital de España con el Atlántico portugués; ni sobre aquella jarana que un general francés hizo a su homólogo español, cuando al entrar en la ciudad pidió un vaso de agua, del que tomó tan sólo la mitad y dijo que la otra le fuera regalada al Manzanares, haciendo alusión a su pobre caudal; ni aquel otro chiste, que decía que Madrid tenía mucho puente y poco río, refiriéndose en tono burlesco al orgullo pretencioso que los habitantes de la ciudad tenían de su riachuelo; y menos, sobre las Mayras, los canales subterráneos (viajes de agua), que, por razones topográficas y para abastecer de agua a la ciudad, se construyeron -y en esto el Manzanares tiene mucha culpa y mérito-, y que sin duda alguna, decidieron el nombre de esta ciudad que ahora llamamos Madrid. ¡Una cosa no tiene que ver con la otra!, Pero, ¿te gusta Madrid?, dije, entonces sobre la cuarta y quinta franja blanca, casi rozando la medianera donde se encontraban apilados los turistas asiáticos, que sin perder tiempo nos hicieron un sin fin de disparos fotográficos. Ser bueno, gracias... una moneda, por favor, dijo alguien con acento eslovaco, dirigiéndose a los turistas. El sonido de la sirena de la ambulancia, aunque apagado, todavía se escucha. Algún que otro 
desesperado conductor, pisa el acelerador, como queriendo restar buena parte del tiempo, que, ante el semáforo, ha de estar. Me gusta relacionar... establecer conexiones entre esas diversas realidades, que, estratificadas, componen la ciudad histórica y la historia de la ciudad... Y me gustaría, poder contrastarlo con eso que algunos han llamado la indiferenciación de las ciudades contemporáneas, ¿Te refieres a la ciudad tipo modelo único?, Sí, a la desintegración de la ciudad como ser histórico. Sonriendo e irónico, dije, Sería curioso ver la ciudad, - porque otros ya lo han imaginado-, diseminándose... soltando fragmentitos históricos por toda la península, ¿verdad?, ¡Sí, gracioso, y tú en uno de ellos!, ¿no?, Lo cierto es, que no estaría mal... un trocito en Pamplona... otro en Logroño... y hasta uno en Lepe, Yo prefiero la idea de la ciudad como un archivo o laboratorio, implicado en la dinámica de la comunidad, Pues, es bonita..., ¿Qué cosa? ¿Quién?, Eso que dices... la idea de la ciudad que contiene y que también fluye. Incluso, esquemáticamente, sería fácil de llevarla a cabo, de materializarla, ¿De qué manera?, Tal vez, entre otras cosas, fotográficamente... mezclando ilustraciones de distintas épocas... todo, una acumulación para ser proyectada gráficamente, Sí, puede ser, dijo, una vez cruzada la medianera, En la fotografía se produce una conjunción ilógica entre el aquí y el entonces, pero, en el dibujo y las ilustraciones, ¿sucede lo mismo?, No lo sé, ¿y tu?, Yo tampoco lo tengo muy claro... pero en el dibujo se realizan una serie de transposiciones reglamentadas, y la realidad se da claramente transformada; sin embargo, el registro fotográfico siempre implica haber estado allí, No necesariamente... hoy por hoy, ya no es del todo así. La persona con el acento eslovaco, se nos aproximó y repitió lo mismo, Ser bueno, gracias... una moneda, por favor. Como, segundos antes, había intuido que se nos acercaría, estaba preparado para mentirle, Lo siento, no tengo nada, dije, haciendo un alarde de búsqueda en mis bolsillos. Tú hablas de la imagen como consecuencia, comentó, sin apenas advertir que alguien se nos había acercado, y yo, del registro como un acto en sí, Pero bueno, retomando de la imagen: la multiplicidad de capas fotográficas, planos e ilustraciones, funcionaría como con el recuerdo... como estratos de la memoria, como vehículos de traslación, Posibilidades, les veo, Ahora, bien, ¿Qué pensarías, de 
encontrarte una serie de leyendas, imágenes y dibujos de la ciudad, en las franjas blancas de los pasos de peatones?, Dónde dices ¿en las franjas blancas?, ¡Sí! ¿Por qué no?, Registros textuales e impresiones de planos, ¿sobre una franja como ésta?, dijo, deteniéndose en una de las marcas blancas. ¡Sí! Pero no en una sola de ellas, comenté, arropándola hacia mí e incitándola a continuar avanzando, sino más bien, en todas las de un emplazamiento como este. ¡Permiso, por favor!, se oyó una anciana a nuestra espalda. ¿Para qué y cómo?, dijo ella, insistiendo en su detenimiento, Una inscripción hecha sobre una de estas franjas funcionaria como un texto en un libro: remitiéndonos a situaciones paralelas, anteriores e incluso futuras, ¡Éste no es el lugar más adecuado para mantener una conversación, reprochó la voz anciana!, Perdone usted, dije, sin prestarle atención y proseguí, Tal inscripción, siempre nos remitiría a alguna otra cosa o lugar... Pero, además... si está realizada con el mismo pigmento con el que se pintan dichas franjas, se establecería un juego de ocultamientos... como sucede entre memoria y recuerdo... Se establecería la relación ideal entre la ciudad y su memoria: entre la ciudad y su pasado, tal como ocurre en las mentes de las gentes, ¿Se percibiría bien una inscripción blanca sobre el blanco de la franja? Algunos que otros insultos, salidos de bocas desconocida, retumbaron en nuestros oídos. Movidos por las ordenes del guía, los turistas asiáticos, se alejaron en busca de otras miles de imágenes, ¡Sí! La suciedad del asfalto contrastaría ligeramente con la limpieza de los textos... incluso, esa dificultad de percepción facilitaría algo más interesante, facilitaría un encuentro inesperado con un pasaje, dato o historia, de la ciudad en cuestión, Con el uso habitual del paso de peatones ¿qué pasaría entonces?, Ocurriría, dije, al tiempo que el hombre verde del semáforo comenzó a parpadear y juntos apuramos el paso, que tan solo le añadiríamos otro más: el de contar algo alusivo a su historia. Una tautología para reafirmar, ¿no? ¿Cómo que tautología? ¿Dónde la hay? Bueno, en eso de la ciudad archivo... que cuenta y contiene... y lo de las franjas blancas... que pretenden archivar... y también contar lo que ya la ciudad ha contado o está contando. No, no se trata de tautología sino de niveles, de estratos que nos permitirían ofrecer una visión redimensionada del rostro, la memoria y la voz, de la ciudad. ¡Más 
que de una tautología, se trata de una abstracción... de una inmersión en lo macro, que nos envuelve a veces hasta cegarnos! Estarás de acuerdo conmigo, en que sobre el uso de las cosas, pensamos de manera dogmática y para nada democrática, ¿verdad? ¡Sí! Siempre decimos lo mismo: esto es para esto y aquello para aquello. Esencialmente, nunca llegamos a transgredir. ¿Por qué? Dijo, a unos pasos de la acera, No lo sé... tal vez, por incapacidad. Fue así, aun tomados de la mano, que nos detuvimos junto al semáforo y nos volvimos de cara hacia la acera de donde veníamos. Al fin se encendió la señal verde y los coches arrancaron bruscamente...* ¿Volvemos a cruzar? Dijimos, entonces al unísono. 


\section{A.4 LA CASA EN LA FRONTERA, DE EMILIO MARTíneZ}

"Y la más elemental experiencia humana tiene caracteres de revelación". María Zambrano, en Notas de un método. Tres habitáculos en los que transcurren tres tiempos, en los que fluyen tres temperaturas y habitan, si así puede decirse, tres juicios de cosas, dibujan y narran LA CASA EN LA FRONTERA, de Emilio Martínez, y literalmente la triangulan, en una suerte de vínculos que permiten (y suponen) el fluir y la envoltura del uno al otro, disolviendo en apariencia la figura inicial -al triángulo se superpone una cierta sensación de circularidad. Se trata de trasvases: de valores inicialmente contenidos en la memoria de la primera obra, que fluyen hacia, y como continuidad explicítan, el reclamo hilarante de la segunda, y por extensión, la adusta intimidad de la tercera, cual una frase de la que no se podría sustraer una palabra, en tanto que se anularía su sentido; se trata de una metáfora de la resistencia que alude al arte, su función simbólica, su temporalidad, presencia y limites -por cuanto reacciona ante su amenaza de pérdida-, $\mathrm{y}$, además, al hombre y su trayecto paradójico a través del entramado social (y no se trata aquí de explícitos contenidos de carácter político, sino más bien, de la potenciación crítica de las obras, de la reimbricación de su acción problematizadora en otras zonas de lo social, y de su resituación en un camino -minado de imágenes técnicas y tomado mediaticamente-, al parecer dejado al margen, como para que la experiencia no quede reducida solo a esa mira, sino que se convierta en una fuente de experiencias, y en un saber abierto a la revelación). "Una casa que no es la casa", podría haber dicho Rosalind E. Krauss, si de precariedad cuasiarquitectónica se hubiera tratado. Y es de ella que básicamente parte este ensayo plástico de Emilio Martínez, de su interés de redefinición de la práctica escultórica contemporánea, y del arte, de ese "Hacia el centro del campo hay un pequeño montículo, una protuberancia en la tierra, el único aviso de la presencia de la obra", que da comienzo a su visión de la escultura en el campo expandido, que él asume limpio, desprovisto de insinuaciones, y desplaza hasta su zona de intereses e inmediato conflicto. Y aunque tambien -quizás desde la alcoba-, en el cielo de LA CASA EN LA FRONTERA, sobrevuela Catherine David, y casi en sueño, 
Paul Virilio, es de Rosalind E. Krauss de quién toma el concepto que articulan sus obras, desproveyéndolo del cuerpo evocativo que sostenía su primera defensa, pero no para anularlo cual una vulgar negativa, no, sino más bien, para quedase con su cascara-roll piel, aura y papel invisible-, que le es posible mover y encajar en un campo aledaño, como lo es la arquitectura; Y, además, superponerlo -puesto que su familiar vecindad lo permite-, a su idea de la cuasi-casa, a esa construcción nocostrucción levantada al margen y en los márgenes de las ciudades, que, entonces, habría que redefinir en tanto que su ubicación urbana lo demanda: la chabola del pobre y de la pobreza, y en su extensión, el suburbio. Pero, entonces ¿es acaso LA CASA EN LA FRONTERA una reflexión en torno a la casa en el campo expandido, tomando, como hace amablemente Emilio, el concepto de Rosalind E. Krauss? ¿Cabría, en ella, imaginar un gesto nada camandulero y, de hecho, una reflexión en torno a la casa interior en el campo expandido, al refugio del alma del artista, aun por definir y en terreno de nadie? Pues, yo diría que sí, que de ello trata, aunque no de manera explícita, de la casa precaria y de la casa interior: en la trama que articulan los tiempos, temperaturas y, digamos que conciencias. Tiempos, en el primero, segundo y tercer habitáculo, distantes y distintos: uno testimonial, el otro, documental, y el último, intimo, (dar fe, denunciar y mostrarse); que niegan la segmentación que el reloj impone y el viaje incansable de sus agujas, a favor de un estable que crece en sí mismo, cuya naturaleza se afinca únicamente en la fisicalidad y arquitectura de cada pieza, en las temperaturas -palpables en grados e intensidad- que emanan de las estructuras de la chabola instalación, la casa de todos (vídeo room), y de su casa-ambiente, que juntos, aun sin que haya ocurrido la fusión, evocan su problematicidad, como un continuo a una misma voz. 


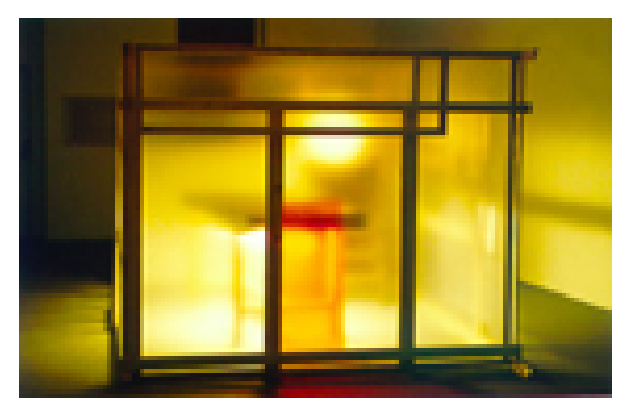

Figura 36: La casa en la frontera. Instalación

LA CASA EN LA FRONTERA es una triada donde conviven otras muchas, casi hasta el infinito. Por un lado, se trata de límites: geográficos, materiales, humanos; de la conciencia que piensa la geografía de la percepción del espacio y tiempo de la ciudad, a través de una construcción precaria, impersonal, provisional... de la imagen de la ciudad contemporánea que evita, y de hecho anula, ese tipo de construcción también moral que solo se da en los lindes, deslocalizada del habitar común y de la huella velada detrás de la opacidad del plástico, como un indicio de algo que se ha querido ocultar aunque es evidentemente visible, y que se oye, a pesar de los tantísimos ruidos que nos acompañan. Por otro, podría hablarse de memoria, de denuncia y de voluntad resistente y de resistencia: de como se ha vivido, como se vive, y como ha de vivirse. Como memoria el project room nos ofrece, casi interminable, tal vez obsesiva, una toma del campanario de una iglesia, de la iglesia de los Angeles - ¿la casa de Dios y de todos?- en cuya fachada, en sentido inverso al transcurso del vídeo, como oponiéndose a la placentera estabilidad y presencia del edificio y su simbología, actúa una unidad electrónica de mensajes móviles que descarta y arroja, también casi sin fin, y bien, no sin sarcasmo, una amplia estadística referida a aspectos económicos y sociales de la comunidad. Entonces, la presencia y el dato, lo real y lo ilusorio, la diaria verdad y lo estadístico, la realidad social y la ficción política, se niegan y, a la postre, desmienten. Aquí se ha producido el primer vertido de un habitáculo en otro: la primera cara ha quedado cerrada, pero no del todo. De la primera sala, 
en la que se encuentra la chabola, el project room ha recibido el trasvase de una sutil, y primera, declaración de intenciones: el reclamo escondido de la denuncia resistente fluye recorriendo una y otra parte de la casa. Por último, el tercer habitáculo, su casa y frontera, ese encontrarse entre ser y realidad, se ensancha hacia dentro, y cuenta sobre sus sombras y sus luces; dice del espacio de recogimiento e intimidad, desde donde brechtianamente alguien (él no-él) nos mira a tiro de ballesta, satisfecho de lo proclamado, y para mas, pone fin al triángulo, cerrado desde una posición de alerta, por si, como se dice, el intruso vuelve. 


\section{A.5 MABEL PALACÍN: SUR L'AUTOROUTE}

"Un coche que se identifica con la cámara recorre un circuito cerrado un número determinado de veces. Allí encontrará, en cada vuelta que da, una pantalla en la que se recogen una serie de imágenes-escenas hechas de sombras chinas, tras ellas y en su recorrido irá encontrando los elementos y personajes que las construyen".

Que se haya construido una obra es, según pienso, aceptado difícilmente por el autor, ya que obra al fin ha de ser llamado el cuerpo palpable, la arquitectura estructurada dada a otros, que bien, habría de llevar hasta sí misma, en su inconclución, lindes de lo que puede escudriñarse en la situación actual, pero manifestándose como un algo integrador -tal vez, un saber- que aúna todos los otros a los que el hombre de hoy se ve sometido. Entonces, la voluntad de la obra, su ser posible, y no el voluminoso estar o ser ya una cosa, es transmisible, materia para ser compartida, porque ante todo es experiencia causal, como la identidad que busca ser causal para diferenciarse de la sucesión en la infinitud -punto unitivo de una combustión y de un espacio que se prefigura.

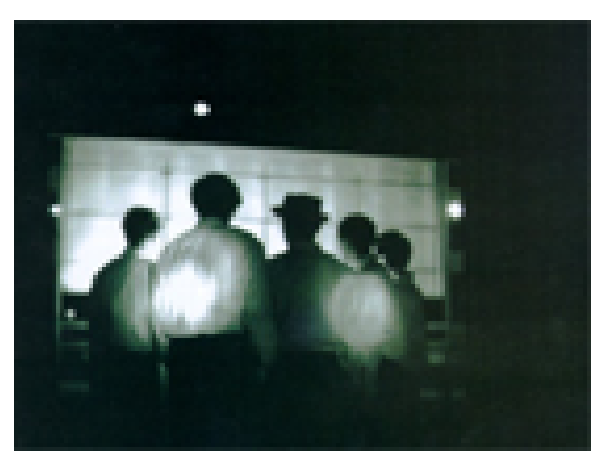

Figura 37: Sur L’autoroute

Y es a través de la experiencia de las experiencias por donde se desliza SUR L'AUTOROUTE, evitando llegar a un final, reabriendo constantemente la misma historia, pero pronunciada, vista, $y$, tal vez, confesada, desde 
otros seres de la mirada que más que añorar se denuncian: que arremeten contra el orden precario de lo que cuentan igualmente desde la precariedad y el casi nada aparente; desde un trazado de imágenes que para nada parece ocultar su proveniencia y familiaridad anterior, o ese haber sido consumidas por alguien, pues que, ese alguien, al haberlas anteriormente asimilado, ya es parte de la experiencia de ella (de Mabel Palacín). Así pues, un acto de problematización de la naturaleza de las imágenes -de la imagen-experiencia debilitada y difusa, de su figura opaca y enferma de multiplicidad- pone en cuestión a los personajes y espectador, dislocando sus ritmos, bien en favor de un transcurrir melódico que sirve de más y para más, porque no marca nada como lo hace el ritmo, sino más bien revela en su imprevisibilidad. "Lo que no es más que ritmo, dice María Zambrano, es un infierno". Y esos pequeños infiernos -habilitados innumerables veces como ficciones que van desentrañando un mismo asunto- que articulan SUR L'AUTOROUTE, al margen de la problemática misma de las imágenes y de su acción ritmática, de la memoria involuntaria, temporalidad y distancia, problematizan poderosamente la idea de familiaridad: de la familia y su orden, del estamento que la constituye, y que en determinado momento es puesto en juego, si no bien, subvertido sin apelaciones posibles. Pero en cuanto a la imagen y su uso, propiamente dicho, la reflexión que de ella hace sur L'AUTOROUTE descansa en un contrasentido, en una negativa tácita al énfasis normativo de "hacerlo nuevo" -recordando una de las reivindicaciones más radicales de la vanguardia, vigente hasta los años sesenta, y que de hecho hay que tener en cuenta- extrañamente incidente en buena parte de la proyección crítica y práctica contemporáneo del arte. Niega por tanto, mas no se trata de una convención, la demanda de asimilar la práctica artística a la estructura de la ciencia y la industria dándole un espaldarazo a toda la imaginería anterior a los nuevos mitos del progreso tecnológico actual: la expansión de las industrias audiovisuales, la iconización exhaustiva del mundo contemporáneo, la progresión de la industria de la imagen, el diseño y la publicidad. Una negativa, porque SUR L'AUTOROUTE en su construcción ha asimilado de todo: a Rossellini en la primera secuencia de "Viaje a Italia", al Hitchcock de "Pájaros", a Nauman y su elevación 
del registro primario y vehicular de la imagen (fotogramas) al plano de obra, de Godard, las tensiones figura fondo y cierto carácter periodístico, de Tarkowski, el movimiento que vacía a la imagen de su peso, como en "Solaris", de Warhol y de Broodthaers; y dignamente así, del vídeo activismo de los años 70, de los primeros monodramas de Stan Douglas, y del juego conversacional de una imagen-secuencia dentro o frente otra, de sus últimas obras, hasta las sombras chinescas del teatro oriental. De ahí que negativa y acierto se abracen saludablemente, haciendo que convivan, puesto que no es incompatible, tecnologización y experiencia histórica, y que la tradición y su uso, y la contemporaneidad en la práctica, estructuren un lazo de insumisión resistente; pero además, porque es visible el derrotero estetizante -ese pretender que seamos usuarios de modelos producidos para el uso y nada más- y control mediático del hoy y de toda práctica, y más, el ejercito y el ejercicio vago que la secunda y consiente, sabiéndose una prenda más por salir del armario. En sur L'AUTOROUTE el relato, que no es por sí mismo algo relatado, concierne a una relación adecuativa entre sujeto e imagen, entre lo que ve, potencialmente falseado, y lo que es en sí, reelaboraciones igualmente potenciadas de un mismo sentido a través de otros. El sujeto es la última potencia de lo falso, y a él se le ofrecen metamorfosis y no formas porque eso es lo que prefiere antes que formas de lo verdadero, que la virtud que da. Pero es el chochecámara recirculando sobre lo mismo, y el deambular constante de otra cámara (siempre objetiva) entre los objetos domésticos y las sombras chinas proyectadas sobre una pantalla traslúcida, lo que asegura la potenciación de lo falso, elevando la imagen al plano metafórico del "Yo que ve", de la identidad problemática y problematizada del sujeto. Y como al relato, también en SUR L'AUTOROUTE le concierne a la imagen una relación adecuativa, por lo que se toma a sí misma por objeto en el proceso constitutivo (el film dentro del film o la imagen cultivada en la imagen), como una imagen-germen que de sí se alimenta, y en su transcurso, está constantemente haciéndose, quizás como un recuerdo, o tal vez la evidencia de que detrás de su acto mismo retumban voces como la de Wenders, Keaton o Fellini. De la casa, sus elementos vueltos siluetas y sombras- crecen casi hasta distorsionarse, tal como 
si su natural fisicalidad ya no importara, sino lo que de ellos como experiencia se tiene, su conocimiento y proximidad algo más abstraída, y por tanto, la visión de unas figuras memorables y reflexivas que han de ir a depositarse en una provincia afín, o cuando así se consiga, en la prontitud cercana y reversible del filosofar. Son elementos cuyo actual presente comprende literalmente el pasado de sus presencias, la virtualidad de la imagen que las trasciende suspendida en su uso, quedada como concepto, más que como constancia tangible. Es por tanto la casa, (igual L'AUtoroute, el camino), un habitáculo memorable que acota el recuerdo y el cuerpo virtual de lo que la ha habitado, superado o no: del mobiliario, contingencia de familiaridad, o no. En cuanto al padre (los padres), pues tal es su legitimo papel, éste siempre ordena y escudriña en el orden; trama, por así decirlo, en lo histórico, en un panorama doméstico que, aunque se le revela, él pretende hacer ver como ordenado y estable. Pero tal evidencia, mas que una ofuscación -pues la ofuscación al final se disipa- hay que verla como una pretensión de llegar hasta el lugar de la vida de los otros, de los que además de él habitan la casa; y tanto, porque habitar un lugar excepcional exige una condición humana común y una misma ley, incluso, sabiéndose de antemano que esa ley, que esa disciplina ética, será violentada por otra disciplina social, como ocurre con los niños/as que los sobrepasan en dimensiones y ordenes, como algo surgido de la pasividad del placer y de la acción ordenativa de sus propias progresiones en la vida. El padre alucina, no de locura, sino más bien de evidencias; por la evidencia propia de las redimensiones de las cosas que temporalmente lo superan, y que sin más trascenderán su orden: el patrimonio ideal costumbre, moralidad y propiedades- que como legado ofrecerá a sus descendientes. SUR L'AUTOROUTE, como una reflexión sobre la naturaleza de las imágenes - ¿y acaso el hombre y su mundo de hoy no son una imagen, una noción genérica que hemos inventado para poder reflexionar sobre su condición?-, y un recorrido emparentado con la road movie, parece advertirnos (para que ni los equívocos ni las narices crezcan) de la excursión que hasta aquí le ha traído, y que su voz, aunque aquí se escuche por igual con otro acento, ha de buscarse, como primera condición, en el silencio. 


\section{A.6 LOCALIZACIONES: LA HUELla QUE HUYE}

"Un alfiler es suficiente para hacerse con la mudez de un mundo entonces por iluminar -dijo Petronila Rubalcaba, e hincó su fina punta en una de las paredes de la pequeña caja hasta atravesarla; luego cerró los ojos, como para no ver ni pensar en toda la luz (esa mucha luz) que la había penetrado y que en lo adelante haría de su negrura e interior una semioscuridad 'patas arriba' que para nada se había panteado"3.

Incidir sobre algo (digamos una superficie) movido únicamente por la idea de que desde su interior es posible extraer también algo, ha de devenir -se encauzará- necesariamente en la vislumbre caótica de un sinsentido que, bien puede salvar la ilusoriedad del propósito, darlo a conocer o forzar que sea re-conocido; o bien, sumir tal persistencia, ese asomarse audaz, en el más absurdo despropósito e igual furibunda hostilidad. Sin embargo, lo cierto es que la segunda de las posibilidades es la más dada a ser consumación. El intento, por más que otra cosa plantee, supone una cierta preexistencia; supone, que antes de que la cosa lo fuera, en ella, habitaba la realidad a extraer. De hecho, se pone en juego una cierta abolición de la realidad cuestionada, en favor de un anterior estar; de la construcción de un vacío operativo que justifique la acción, solapando la expectativa tendida sobre un firme aparente. "Nuestra vida así transcurre colmando vacíos...,"4 plantea Bergson, entorno a la falsa problemática de la nada. Atiborramos, claro esta, el vacío que como creadores de utilidad concebimos, que armamos ante la ausencia y tras el sentimiento de falta de cosas: actuamos, sin más, para lo que pensamos. No debe haber, por tanto (y aquí, vago sin pudor sobre el pensamiento de quien he citado) motivación alguna para que el asombro nos colme: estamos concebidos para actuar, quizás tanto o más que pensar. Acción e inocencia, muy raras veces van de la mano. Ahora

3 Óraprap, M. Como la luz misma. Ed. Cast.: Piedra Negra, Santiago de Cuba, 1996.

4 Bergson, H. Memoria y vida. Textos escogidos por Gilles Deleuze, Alianza Editorial, 1987. 
bien, al margen de cualquier digresión, esa figura aguda y mordaz del incidir, resultante de una unidad para la acción -última estocada para orientar el rumbo- es la única presteza válida, capaz, para despertar en el hombre dos genios que lo habitan (mas que dormidos, rendidos): uno bueno, que de tan bueno su ingenuidad roza lo imploratorio, y uno malo que de tan malo entre guiños y guiños, su progresión desgarra.

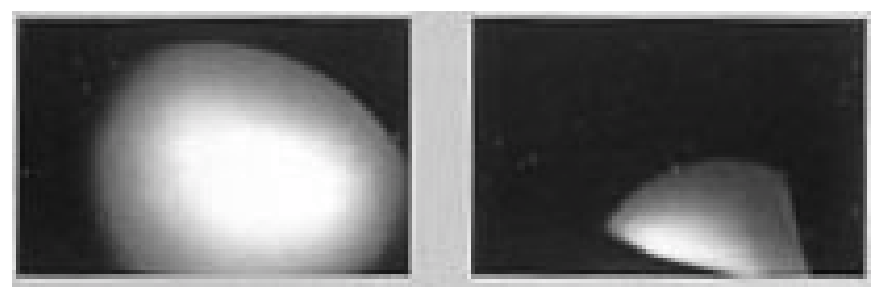

Figura 38: La huella que huye I

INCÍDERE, CAÉDERE, he aquí, aunque impreciso el ángulo de caída, la orden que aguarda dos supuestos tendentes a sendas derivaciones peligrosas: la primera, la posibilidad de que poéticamente la acción solape la claridad de otro enunciado, a la larga sustitutorio (el medio no deduce claramente el fin); y la segunda, en tanto que puede herirse de muerte, nada más imaginarlo, la quietud escondida detrás de la cápsula-piel, la presunción lógica de que lo que detrás de ella habita, en el supuesto de que así fuera, lo es en principio sin serlo, y aún más si se quiere al margen del más audaz vuelo imaginativo. (Esa mucha luz) que escuetamente describe M. Óraprap, de la que Petronila no quiso ver ni imaginar su dimensión proyectada, más que luz, más que abundante claridad, es en sí misma -siendo por igual, el acto y la reacción propia del acto-, una situación violatoria, un penetrar rasgando la nada y el pasado. Tras la incisión, el fogonazo de luz que sobreviene hasta el interior de la caja suscita en ella una exagerada y profunda tensión que, por vez primera, la hace detenerse ante su propio acto $\mathrm{y}$, además, contemplarlo cual una imagen anaglífica cuyo motivo no transcurre por ser único (pasivo), aunque por otro lado su progresión (permanencia) se torna más que intensa. Y puesto que la experiencia la obliga a captar la relación entre la legibilidad de la caja, la oscuridad 
interior y la impronta de la luz, la observación particularizada en un continuo veloz se muestra re-descubrimiento. A la voluntad de no ver ni imaginar que Petronila asume ante la impronta de tanta luz, se ha antepuesto el vértigo contradictorio de haberse visto contemplando la acción misma de ver, y a su vez, la severidad de que tras ese ver-saberseviendo, lo único posible y de hecho acto de consumación inmediata es el reconocimiento. De ahí que esa voluntad de no ver ni imaginar, sea una voluntad de regreso compleja y paradójica en sí -el viaje hacia la oscuridad interior de la caja no puede ni debe ser continuado por ella en tanto ya ha sido viaje real, y corresponde entonces a la intuición y pensamiento su completamiento y continuidad, que es en fin a lo que teme.

Voluntad de regreso, laberinto espejado o conciencia de alejar el horizonte, podría decirse de ese sentimiento contradictorio que nos lleva a retraernos de la consumación y de su impronta. Tiene el ser una obstinada fijación por lo periférico, una oscura disposición que le anima a estar en la gotera del entrar; que le impone el alejamiento continuo, haciéndolo trazar la ralla imaginaria que evidencia, por tanto, el hecho separado, el ver el horizonte allá, definitivamente distante e inaproximable. Y para no llegar a él, puesto que en ese caso se ha hecho una gran parte del recorrido violatorio, anteponemos una cámara -un espacio laberíntico- que evita la llegada, y así, la entrada definitiva. Entonces es posible imaginarla, vivirla y entenderla, pero solo como ficción: se está adentro sin estarlo, sin el trazo; puesto que el adentro trazado es el afuera.

En este caso, Petronila ha violado y visto el acto de su violación, el descubrimiento de su propia sombra 5 . Por ende, ha roto el cerco virgen de la oscuridad (del jueguete-cámara de oscuridades que es la pequeña caja), añorando tal vez hacerse con esa claridad esencial, que se dice, late en perpetuidad en toda figura. Apoderarse quizá de la blancura que, más que sustraer a priori había depositado en bien y para el bien de un gesto que, sin lugar a dudas, y aún mucho antes, había sido

5 De los Ángeles, Álvaro. Recuerdos, arañazos y otros actos vandálicos, Ed. Institut Valencià de la Joventut (IVAJ), 1999 
predefinido como irrefutable, creíble y, además, cierto. Así, entre la acción violatoria y el acto seguido de reconocimiento, ha tomado cuerpo, aunque potenciado en anteriores violaciones un grito liberador. Detrás de toda búsqueda subyace un grito por ser, un ¡Sálvame o ayúdame Dios! que roza los dientes, aunque aun así ensordecedor. ¿Acaso esa luz transgresora que irrumpe en la caja de solo oscuridad o en un paquete de mediana negrura, esa realidad puesta patas arriba en su interior herido, no es un grito? ¿No es un hacía fuera lanzado hacia dentro, un bendecir la fisura -para siempre- como legitima y/o posible? Alfiler y mano juegan entonces a ser el mismo y preciso artilugio, al margen del advenimiento de una realidad dada como una evidencia supuesta: el todo ha comenzado siendo un diminuto agujero para atrapar claros y antípodas: un estenopo, por el cual, una vez, ha de filtrase un fragmento de lo re-conocido, y otra, el azar secuenciado de lo que nos envuelve. Tras los o' $5 \mathrm{~mm}$. de huella dejados por el alfiler se desata una verdadera tormenta: un torbellino de velocidades continuadas. El alfiler, la caja, e incluso la mano, han devenido en un vehículo de aceleraciones que va tiranizando cada grado de oscuridad con una realidad por ser; con antípodas poéticas al parecer azarosas, que habiendo recorrido un minúsculo espacio se prefiguran como signos de un lenguaje en cierne que, aunque primario y aún deslizándose hacia la reducción, soporta, más que portar, la consistencia de poder convertirse en una razón, en una protesta de singularidad. La luz, tal vez en ese instante más rápida que lo razonable, por tanto, imprecisa, parece adueñarse del porvenir y acelerarlo como pasado. De rastros y evidencias: una porción del trazo.
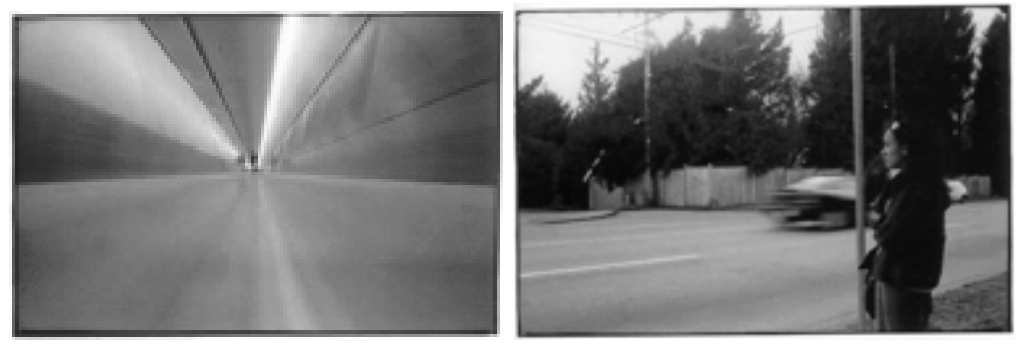

Figura 39: La huella que huye II 
Mas que una mancha de aceite, de oliva o de colza, la huella parece ser un ruido; parece estar actuando como ruido y ritmo de una materialidad a la que no corresponde. Parece ser una repetición tan sólo por la similitud que guarda con la que le antecede y prosigue, en relación con el tiempo en que le ha correspondido potenciar su esencialidad: ser "ahora" solo cuando se le necesite, cuando se active el propulsor adecuado o haga el clic decisivo. Así más o menos transcurrieron los años medios de la década de los noventa: entre parecer y ser, más que como argumento, como duda -y aquí me apodero sin reparos del concepto de Raoul Veneigem para que el supuesto prospere-, respecto a la explosión del placer vivido, en relación con el proyecto de vida y de obra: perdiéndome en él, ¿me encuentro?, olvidando quien soy, ¿me realizo?, forcejeaba la incertidumbre. Pero claro, tal vez no podía hacerse más. De ahí que la mirada fuese hacia la longitud del camino, hacia la evidencia del cansancio que había de suponer el recorrido, como de igual manera la reflexión restringida a lo vivido atentaría contra ello, reduciéndolo anticipadamente a simples recuerdos. Aparentemente la obra no era más que un testimonio neutro, alejado de la mínima aura o pretensión de artisticidad, cuyos vínculos quedaban reducidos a unos pocos aspectos técnicos manejados en su momento, como era también de aparente la mirada hacia allende los mares el fragmento y su potencialidad documental. Sin embargo, desde esa lejanía y dirección de la mirada ipodía realmente concebirse el todo, la totalidad de lo vivido? ¿Podía acaso concebirse el fragmento, la parte ínfima de la totalidad, siendo a la vez fragmento y negación de sí mismo? Vestigios palpables insinúan que no. Pensamiento y proyecto, parecen haber estado desligados de la experiencia vivida. Las abstracciones y nociones recurrentes a ella, fueron quizás justificaciones que de ninguna manera la corregían, y menos aún revertían su uso como un valor a reconocer en el futuro, en tanto que riqueza creativa tan distinguible como la riqueza creativa universal. Por ello, no es de extrañar que el usufructo del patrimonio hallado por las nuevas prácticas creadoras de lo visual no haya sido, del todo, una consecuencia sino una noasunción, entre ciertos márgenes de precariedad, de ese parecer y ser marcado por un estado de incertidumbre, cuya relación con la técnica 
desdecía su conocimiento práctico en profundidad, sumido o asentado en la comprensión genérica de un modo específico de experiencia y su manipulación gracias, entre otras muchas cosas, a la industria audiovisual. Es curioso, que ruido y ritmo, en el supuesto de que sustituyeran la mancha primaria, actuaran como presencias atemporales, como sustitutos sin memoria, o en su lugar muy alejados de ella. El recurso, por tanto, parece haber sido la duda de la fragmentación; la proyección del dudar ante una incertidumbre abocadora de una universalidad parcializada y sin centro; ante la negligencia salvaje y corrosiva de la contemporaneidad, extendida como principio desde el desorden hasta la perdida de la memoria histórica, cuya desproporción se encaminaba hacia la implantación de la apariencia como orden (el mero acto de aparentar) y, por consiguiente, la sofisticación del entorno: todo iba bien, todo parecía ir bien. Ello deducía entonces una consideración parcial tomada sobre el todo, que alejaba toda posibilidad de recomposición del conjunto, históricamente dicho, cultural. Tal como cada punto de la curva se confunde con su tangente, el quehacer artístico se proyectaba confundido con su posibilidad: no refiriéndose a lo que era, sino a lo que no era en tanto que las formas de hacer, el seguir el movimiento de su naturaleza, se aventuro fuera de lo que constituía su campo para actuar tan sólo por lo que se pensaba.

"El encuadre debe ser casi panorámico, pero que restrinja el trozo de la carretera, de manera que está se convierta en un personaje secundario como a de serlo el primero de los coches que la atraviesen", debió decir "Alguien" al borde de la carretera, instantes antes de que se produjera la filmación de aquel fragmento de realidad y ruido que posteriormente sería desmaterializado: primero en un magneto, y luego, en la proximidad inminente de un ordenador. Pero puede también que nada parecido a tal supuesto haya tenido lugar, y sí, que aquella acción de ordenamiento de la imagen -tal como es, tal como se ve- habría de devenir en la desmaterialización del dato en sí registrado, en orden matriz y ordenamiento underground; en el principio de un proceso cuya unicidad consistiría en ser reflejo de un modo de percepción, integrando el rastro y el ruido mismo de la imagen en la secuencialidad 
de una nueva ordenación todavía próxima a una fisicalidad casi objetual. El proceso y el medio enfatizarían, por tanto, el fragmento -la huella de aceite abstraída de su entorno actúa tan solo como una porción de la totalidad a la que había pertenecido. La fugacidad del coche como figura veloz, deberíamos entonces entenderla como una figura pasiva a pesar de su constancia, circularidad e inversión momentánea. La imagen fugacidad del coche está compuesta por dos elementos ruidosos: uno, la huella residual de un automóvil en marcha; y dos, el sonido también residual del motor del automóvil en marcha. Es dicho ordenamiento, según apreció lo que en el efecto final dota a la imagen de pasividad. Fijémonos que el intento de producir una cierta intermitencia y arritmia emanada de la distinta ubicación de la misma figura en la secuencia, tiene un trasfondo cuyo significado es inevitablemente la pasividad; pasividad que permite, por tanto, que la densidad repetitiva del motivo aflore en el modo de percepción, al arrastrar consigo, más que la enumeración ubicativa del motivo, la masa constante de su unidad primordial. De rastro y evidencia es de lo que se trata -de una proción del trazo que, extendida a otra espacialidad, fundamentalmente visible, da forma a un significante cualitativo, a la condensación del interés por una comunicación directa que sustituya el supuesto dudoso por lo esencial: por el registro del acontecimiento, y técnicamente hablando del "tiempo expandido"; capturado definitivamente como dato sustentador de memoria, del ordenamiento de un tiempo casi pasado. -La relación aceite, ruido, más que una cuestión nacional, es una cuestión generacional -dijo "Alguien" en ese instante, aunque, a decir verdad, hacia muchisismo tiempo que a tal conclusión había llegado. Entonces dispuso la cámara en el lugar escogido. Era una Bolex del 56, todavía de piel negra y resguardos de acero niquelado que hacia juego con el portalentes de revolver, también niquelado; toda una joya para coleccionistas entendidos. Asomarse, sin más: la quietud del viajero. 1 "Gracias básicamente a ese desarrollo técnico -que actúa como una especie de segundo obturador, expandiendo el tiempo de la fotografía al ensanchar el tiempo de captura en un segundo tiempo de procesamiento, de postproducción- la fotografía se ha vuelto narrativa, toda vez que su tiempo de exposición se ha expandido más allá del 
instante abstracto de la captura"6. Una vez activado el obturador la visión queda interrumpida, cede ante una oscuridad que igualmente ha de ceder ante una pregunta; oscuridad que, más que dar paso a esa necesaria sustitución, deviene en ella cual si poética se volviera la disolución. Pero, el tiempo interior, la sensación expandida, ¿ha tenido efecto? ¿ha sido capturada? Quién porta la cámara fotográfica es indudablemente susceptible de la perturbabilidad de esas preguntas. De quién fotografía, a la vez que la mirada se intensifica sobre el motivo elegido, la incertidumbre en cuanto a su desarrollo final como imagen -su captura y expectativa de conocimiento respecto al ámbito cultural de donde se extrae-, es puesta en duda, en tanto, entra en juego el conocimiento o no del plano exposición (entorno de estancia final o de transito) y su capacidad para alterar la selección: su necesidad interna y genérica. Todo transcurre en un segmento de tiempo muy breve $y$, a la vez, más que intenso. Sin embargo, ese transcurrir, ese fluir como distancia reflexiva, es únicamente operativo entre el ojo que ve a través de la mirilla y el dedo puesto, y dispuesto, a activar el obturador; distancia pequeña, dada la cercanía entre la mirilla y el dedo accionador, e inmensa, como dialéctica de una progresión en el ámbito de lo mental. Se esta entonces próximo a una proyección imaginativa, cuyo reclamo y despliegue debe culminar como la estructuración primaria de la obra. El clic ha dado paso a un recogimiento casi absoluto, tras el cual, el simulacro constructivo -digamos, la activación de un segundo obturador, un tiempo procesual postfotográfico- ha comenzado a tener nombre propio: dar cuenta de la experiencia, del crecimiento del acontecimiento tras su captura. 2 "Einstein, al especular sobre el espacio y el tiempo, recuerda a su manera que Dios ha muerto. En cuanto el mito deja de englobarlo, la dislocación del espacio y del tiempo arroja la conciencia en un malestar que hace las delicias del Romanticismo (atracción de los países lejanos, añoranza de un tiempo que huye...)"7 El viajero siempre ha de llamar a una puerta: primero, para ser recibido;

6 BREA, J.L. "Transformaciones de la imagen-movimiento". Ed. A. C. Acción Paralela N ${ }^{\circ}$ 5,2000

7 Vaneigem, r. Tratado del saber vivir para uso de las nuevas generaciones, Ed. Anagrama, 1998. 
segundo, para dejar constancia clara de que proseguirá. La ilusión que lo nueve es la de que el futuro tornará su experiencia en pasado, en el dato como evidencia, que es lo que consta: el acontecimiento por narrar, la fuente referencial de la que una vez tras otra echará mano mientras ande. Así, en Localizaciones, el dato evidente -legado por ser y para ser, traído en la mochila y luego constituido en dos maneras de ser lo mismo- me empuja (puesto que su raíz está en el viaje y no en el pretexto) a entenderlo emparentado genéricamente con el hacer fotográfico, en tanto no está determinado respecto a ello, y sí en relación con la idea y su posibilidad: en torno a una actividad fotográfica distante. El recuerdo de una sensación fotográfica es capaz de sugerir la sensación fotográfica en sí. Las imágenes cubren el secreto que finalmente deben confesar: que su relación, más que procesual, es de sentido -original y sucedáneo asedian constantemente los roles que por herencia les han sido asignados, sustituyéndolos por unidades evocativas, por representaciones algorítmicas, cuyo poder sui generis de sugestión es la grafía de lo que no son, de lo que todavía podrían ser. Sin embargo, en ello no hay suerte fotográfica, y sí, propósitos fotográficos, no sin el cierto margen de ortodoxia que corresponde; figuraciones discontinuas "comparadas", cualidades sensibles que dejan ver, según el ámbito procesual técnicamente atravesado, las nuevas cualidades en que se han transformado: de ser en principio unos datos o momentos evidentes, a ser entonces momentos siguientes, pero de duraciones figurativamente matemáticas. Mochila en mano -tal es al menos mi conclusión, y como espero-, las cuestiones relativas al viaje procesual e intuitivo, a su distinción coyuntural, debe plantearse en cuanto a su temporalidad antes que a su espacialidad. Entonces, el viajero y su acompañante (al margen de las susceptibilidades que supone portar un artefacto tan calibrado como lo es una cámara fotográfica) y puesto que la proximidad entre ambos es más que coincidente, deben plantearse tan sólo el proseguir: la nueva puerta donde llamar, ese ¿Qué, seguimos? que indudablemente entusiasma, y que por suerte en mi tierra, más que para comprometer, se dice con la mano extendida. 


\section{A.7 DEL PASO PRIMARIO A LA AVENTURA POSIBLE}

Que hayamos decidido ir a ver las exposiciones ARMONÍA Y LUCHA DE CONTRARIOS y EL DISEÑO DE LO HÍbRIDO, de los hermanos Iván y Yoan Capote, fue cosa de Jorge Fernández, que nos informó, cual una azafata de congresos, los pormenores de cada una de las exposiciones que sin falta deberíamos ver, y ante la imposibilidad de acompañarnos, nos ofreció sin reparo su coche. ¡Déjalos en Línea y G, frente a la Galería Habana!, dijo resuelto, refiriéndose a su chofer oficial, quien primero asintió, y luego, como siempre ocurre en esa relación entre el jefe y su subordinado, le informó de su posible recorrido y lugar exacto donde estaría para su posterior localización.
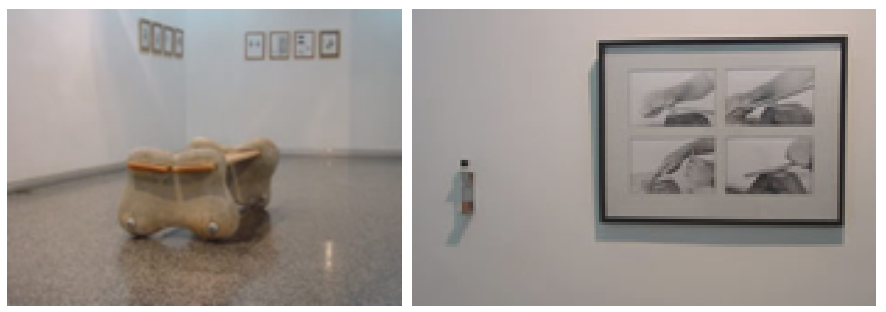

Figura 40: Armonía de contrarios y el diseño de lo híbrido

Minutos antes, ávido -y la avidez en el cubano, lejos de ser un trastorno comunicativo, es una posesión mágica del don de ofrecerse con palabras al otro-, y capaz, cual un maestro cuya defensa de sus discípulos más que pasional es un viso flagrante de amistad leal y de franqueza, Jorge nos había leído y comentado, entre llamadas de telefónicas, portazos y el ofrecimiento de una taza de café, algunos de sus textos referidos a sus intervenciones en varias de las tesis de grado defendidas por los alumnos de la promoción saliente, y sobre el trabajo investigativo y pedagógico de profesores como Lázaro Saavedra, tutor e impulsor de la experiencia-proyecto ENEM@, y de Rene Francisco, con el proyecto Galería Dupp (desde una pragmática pedagógica), del que han formado parte Iván y Yoan Capote. Ha ganado el Unesco Prize for the Promotion of the Arts, comentó alguna vez entre líneas, ¿Quién, y con 
qué?, El grupo Galería DUPP, con un proyecto de intervención pública titulado "1,2,3, Probando", ¿Uno, dos, tres, probando, como dicen los técnicos de audio, para comprobar la calidad del sonido?, Sí, sí, algo tan sugerente como "1, 2, 3, probando" y la instalación de casi trescientos micrófonos -eso sí, fundidos en hierro-, en el castillo del Morro de La Habana, argumentaba en el instante en que la señora encargada de traernos el café, penetró forzosamente en la oficina, antes, empujando la puerta con un suave golpe de hombro, y luego, calzándola con uno de sus pies, puesto que en ambas manos sostenía la pequeña bandeja en la que se centraban las tres tazas de café: toda una muestra, claro está que nada engolada, del desconocimiento de los menesteres y usos del grato oficio de una simple camarera. Aquí está, dijo sonriente, tras un visible guiño dirigido a Jorge. Trescientos son muchos, y peligroso, ¿no lo crees?, dije irónicamente, El número es lo de menos... sólo medían unos ochenta y tantos centímetros de alto y estaban bien anclados, No es a ese peligro al que me refiero, comenté entre risas, sino a que ante trescientos micrófonos son muchas las gentes que pueden hablar... digo, decir lo que se siente, discursar con el ímpetu con que sólo unos pocos pueden hacerlo. ¡Déjalos en Línea y G, frente a la Galería Habana!, había dicho a su joven chofer -después de dos largas horas de intensa conversación, y antes del definitivo ¡No los demoro más!, dirigido a nosotros-, cuando, como por arte de magia, otra persona, una mujer más bien joven, lo intercepto e hizo desaparecer tras una de las innumerables puertas habidas en el largo pasillo repleto de oficinas. Tal como en cualquier otro entorno sociocultural, el artista cubano también es arrastrado por las tónicas colectivas de su época, y de igual manera, amen de los pequeños matices, al propio tiempo pugna por subsistir, por sobreponerse a sus imperativos, como tal. La construcción resolutiva de un discurso constituye para él, como lo es para el creyente, algo así como la salvación del alma; por tanto, la salvación (aportación contributiva) de la época, del inmediato trascendente, que siempre crece anómalo, obstinado y veloz. El discurso, -entonces entendido como una estructura enunciativa y diferenciadora, que sobrepasa cualitativa y moralmente la idea de consecuencia-, y la época, planteada como situación de imperativos utópicos redefinidos, no conforman el devenir unitario que se cree. Más 
que complemento, sentido recíprocamente dialéctico, o sustentador por negación o por afinidad utópica-, el primero, ejerce como una neoproyección, como una entidad arquitectónicamente diferente que ya no discurre como negación, por cuanto antes, prefigurada como pugna, en sí misma lo fue. De ahí, que todo discurso o arquitectura enunciativamente resuelta, sea de por sí, una superación definitiva de la segunda, de la época, de sus imperativos y tónicas. De ellos deducimos entonces que las prácticas y discurso artísticos concebidos en los 9o, generacionalmente no responden como tal -pues ya hubo una generación consecuencia y consecuente (la de los setenta-ochenta), a los postulados y expectativas sociopolíticas que fundamentan la idea de revolución. Quiere esto decir, que el proyecto generacional desarrollado en los años ochenta y sus prácticas discursivas, fueron, por tanto, las verdaderas respuestas reflejos del ideario y proyecto político de la revolución: no es, así mismo, descabellado conceptuar a aquella generación como "la de la acción cruzada", la políticamente correcta, pues lo que -generalmente para la crítica-, fue entendido como práctica artística, era en verdad, una actitud política: Así, para el artista de los ochenta, lo que fungía como prácticas enunciativas artísticas, era, al contrario de lo que suponían, el redescubrimiento (entonces herencia práctica) de un talante de índole visiblemente revolucionaria y política. Unos treinta minutos, atravesando de lado a lado la $5 \mathrm{t}^{\mathrm{a}}$ Avenida (hoy más $5 \mathrm{t}^{\mathrm{a}}$ Avenida que nunca), luego la calzada de Línea (hoy menos cuidada que antaño), un fuerte olor a petróleo mal quemado, adelantamientos incorrectos por la derecha, y el calor del final de la mañana habanera, fue todo lo necesario para hacer el trayecto hasta la Galería Habana, en cuya entrada permanecían dos jóvenes, al parecer en espera de alguien. Nada raro, pues el cubano siempre está en espera de que algo suceda o de que alguien, como tal, aparezca: hacer la media (una media) es una constante. Lo pertinente ante un cruzamiento obligado era extender un saludo, y así fue, mientras nos adentrándonos en la galería y en un sudmundo de objetos y artefactos, sorprendente y atípico, compartido por los proyectos ARMONÍA Y LUCHA DE CONTRARIOS, de Iván Capote, y el DISEÑo DE LO HÍBRIDO, de su hermano Yoan, también, de apellido Capote, quienes al final resultaron ser esa pareja de 
jóvenes, que a la entrada de la galería al parecer -haciendo una media-, esperaban a alguien.

De ARMONÍA Y LUCHA DE CONTRARIOS Y EL DISEÑO DE LO HíbRIDO, quizá lo que más sorprende son los visos de discurso unitario y negación superada, que de conjunto proyectan, a fin de que la totalidad no sea reducida a la simple visualización de objetos comunes o maquinales, correspondientes -por obligatoriedad- a un entorno de reducciones. "Nada -dice Iván, en la nota de presentación-, permanece puro frente a la ósmosis a la que nos expone la sociedad contemporánea, con sus fenómenos culturales, económicos y políticos. Las diferencias, y su entendimiento, se hace posible a partir de la creación y observación de un término: los límites". Y como expresa, es a base de esa difícil concreción de lo limitativo, de esa acción divisoria y simbolización de los contrarios, como ha podido llevar a buen término, piezas como "Móvil perpetuo", un ensayo fotográfico, cuyo enunciado funge de crítica al trabajo y al sentido de la productividad como una relación de intercambio, en la que desde la acción de limar una moneda, y el recogimiento del sudor derramado en la acción, consigue la concentración de dos residuos, entonces opuestos: por un lado, las partículas residuo de la moneda (concepción de un sólido), y por otro, toda la sudoración emanada de su cuerpo (conceptualización de lo líquido) en el acto de limar. El trabajo de Iván trata sobre lo cíclico abordado desde una doble articulación de lo maquinal (doblepinza, diría Deleuze, refiriéndose a un contenido y una expresión) ${ }^{8}$, de la máquina que establece la relación de esos contrarios que al mismo tiempo simboliza. Mientras la máquina despliega su ser (uno y otro contrario), produce una distinción real, isomórfica, aprehensible por tanto, como un redescubrimiento de lo que entonces ha sido un descubrimiento colectivo. Los límites y lo cíclico, unas veces figurado como documentación performática, y otra, desde la maquinización de lo que como acción, en principio, no es constante, llega entonces a adquirir una dimensión de territorialización propia, de agenciamiento de los estratos heredados, como en "Móvil perpetuo" -obra que ironiza

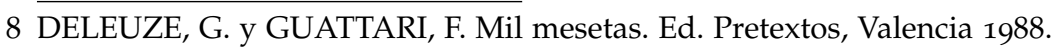


sobre un universal: el trabajo como forma, sin más, de obtención del dinero. Un hacer concreto $\mathrm{y}$, sin embargo, ante un compromiso de obligatoriedad, repetitivo, constante-, o "Armonía de contrarios", que los decide como un comportamiento simple.

La contraparte de ARMONÍA Y LUCHA DE CONTRARIOS, al margen de la sugerencia, distensión poética de su titulo, y el marcado interés por un trasfondo simbólico, es EL DISEÑO DE LO HíbRIDO, de Yoan Capote; un proyecto en el que el valor de su contribución pende del funcionamiento del objeto en relación con el cuerpo del espectador, de una cierta interactividad entre el objeto funcional y quien lo presencia. Cada construcción, aunque quizá no de manera explicita, plantea una intención intermediadora, performática, inducida al espectador; de manera que cuando alguien se sienta sobre la pieza, (sin querer o queriendo) extiende, en cuanto modificación de su significado, su estado de apariencia solamente objetual, hasta el nivel de una experiencia simbólica, como una reestructuración de la relación sujeto-objeto, espectador y obra, devenida en hibridez. En este proyecto expositivo, tal vez sugerente premura de una tesis, las obras filtran -cosa propia de una condición circunstancial, de un pre-discurso, de un discurso, diríamos, que por ser - como cuerpos al margen, un doble referente: por un lado, los usos de una tradición histórica representacional y objetualista; y por otro, "un uso alegórico de los lenguajes"9 -tal como expresaría J. L. Brea-, la inducción duchampiana de hacer participe al receptor en la articulación posterior de la significancia de la obra: representación, nulidad y alegoria, constituyen por tanto y debería reconocerse como tal, esa hibridez puesta en juego por Yoan, y a la que apuntan sus piezas como objetos performáticos inespecíficos. "EL DISEÑO DE LO HÍBRIDO" y "ARMONÍA Y LUCHA DE CONTRARIOs" prefiguran, más como hallazgo (casi casual) que como conciencia de época, la peligrosa entrada -tardía por contrasentido- de los modos y usos cubanos en la dinámica de la industria cultural y de consumo, que empieza, visible en una irreversibilidad fulgurante, a modificar el sentido de la experiencia, en una aproximación desmedida, nada cautelosamente legible, a los

9 BREA J. L.. Nuevas estrategias alegóricas. Editorial Tecnos, S.A., Madrid, 1991 
dispositivos de los grandes poderes articuladores sólo de recepción, de por sí, dispositivos reaccionarios y de estandarización del control. Advertencia o no, "EL DISEÑO DE LO HÍBRIDO", la hibridez como condición -representación, nulidad, alegoría- acentúa la desfiguración de un algo cultural que ha devenido, o está por devenir, a pesar de los resquicios de la gran utopía, en no ser ni una cosa, y claro está, ni la otra. ¿Sabes cómo se pronuncia tu nombre en catalán, aunque se escribe con "J"?, le preguntamos a Yoan, casi al final del encuentro. Sí, claro está, como yo lo escribo, con "Y"... Pero eso no fue cosa mía..., sino de mis padres que decidieron cambiar la "J" por una "Y", debido a que en la época en que nací estaba de moda el uso de los nombres de origen ruso, y para que, al menos en la escritura, tuviera algo que ver con el modismo la colocaron así, sin más. En esos años la "Y" se colocaba -tal cual si hubiera sido entendida como una cuestión nacional, o política-, lo mismo al principio, entre letras, que al final. ¡Se ponía donde quiera!, dijo Iván, sonriente. ¡Quizá, se tiraba!, ironizamos. 


\section{A.8 DESDE ESTE LADO DEL PUENTE: SUSTITUIR LA HUIDA}

La acción recíproca entre sentimiento (precariedad y aspiración) y memoria (utopía y tal vez su disipación) provee, (más bien genera, concebida entonces, no como proceso orgánico en la actividad generativa de saberes, sino, en su caso, como un accesorio de/ y para ocultamiento rápido y efectivo de producciones de valor: sustitución por interpretación, contenido por enunciado, compromiso por solapamiento, consignas por ofertas, dólares por pesos, etc.) la principal fuente de la sustanciación práctica de muchas de las nuevas formas de producciones visuales en el contexto plástico de la Cuba de hoy. Verdad es que una cosa responde a los estímulos de la otra generando estados de apariencia poética, sustituciones ligeras de datos memorables que han de repercutir, como novedad, en el ámbito o área dispersa de lo aprobatorio, bien como reafirmación de una perdida definitiva o bien como legitimación de lo ausente: del dato borroso o borrado, o la reposición teatralizada de lo que, por oposición, aparenta no pertenecernos. Al hablar de volumen I -de la exposición, pues ese fue el titulo de aquella irreverente y desacralizadora, tal vez más simbólica que real, conjunción de objetos y actitudes en el Centro de Arte Internacional de la Habana, en diciembre de 1980-, por ejemplo, intelectivamente recordamos recuerdo a José Bedia, Flavio Garciandia, Rogelio López Marín (Gory) Juan Francisco Elso Padilla, Ruben Torres-Llorca, Jose Manuel Fors, Leandro Soto, Gustavo Perez Monzon, Ricardo Rodriguez Brey, Isarel Leon, y a Tomas Sánchez; y así, a cada uno de los artistas que constituyeron aquella avanzadilla que proyecto y redimensionó el arte plástico cubano, por tanto éstos, a su vez, despiertan en nosotros, en mí, una emoción como igual sucede con las imágenes y las metáforas que aun siendo registros "reales" o igual "parciales" nos remiten a su imaginario primario, directa o indirectamente. De Bedia, me sobrevienen imágenes, entonces posteriores, como su exposición Persistencia del uso, 1983, o su instalación "El golpe del tiempo", exhibida en la Primera Bienal de la Habana, 1984; de Humberto Castro, "La caída de Ícaro"; de Elso Padilla, su excelente pieza-ensayo sobre la figura de José Martí y su ideal latinoamericanista; de Flavio, su exposición 
"Vereda Tropical", en la Galería Habana, 1982, que más que reafirmar la continuidad meritoria de la que tanto se ha hablado de volumen I, más bien pone en entredicho el estirado y ciertamente engreído engolamiento de las modernas prácticas del arte plástico cubano; o sin ir más lejos, la exposición "Espectador", 1983, de Arturo Cuenca en el Museo Nacional de Bellas Artes. De un efecto boomerang, del problema que la utilización quizá reutilización de la imagen, de la cita iconográfica que sustituye -aunque aquí reduzco su valoración al tratamiento consecutivo de su carácter sólo figurativo-, y que sin querer o queriendo, suscita, es de lo que se trata y de esos ciertos peligros ya insinuados en "Vereda tropical" por Flavio Garciandía. En "DE ESTE LADO DEL PUENTE", exposición tramada en tres niveles de hacer, en el que todos esos niveles suspenden la versatilidad de un mismo individuo $y$, a la vez, cada posibilidad disloca los resortes unitarios de la definición de proyecto, se me antoja pensar -refiriéndome a la serie sobre lienzo que da titulo a la muestra y a la instalación titulada "0.53.7"- en una especie de usurpación pasional que recrea el mito y a la figura mítica referente, aún corriendo el peligro de que, como sucede, según Marc Augé, (y aquí parafraseo) las figuras metafóricas no jueguen otro papel sino el de simples sustituciones de unas imágenes antecesoras que como primarias, más que primeras, reaparecen intermitentemente reduciendo los gestos re-figurados a entidades ilustrativas, las traducciones de los términos intuidos a conceptos imprecisos, y por tanto, la sustitución de imágenes prestadas, tal vez pre-estadas, a sus propias referencias: "donde dice digo he dicho, he querido decir, Diego". Ocurre, cuasi como un orden legítimo, que la figura primaria referencial siempre subyace, aun siendo obvio el carácter, sentido práctico, e incluso sincero, del gesto que da cuerpo a la figura que anda o ha de andar entre resortes de índole valorativos. En esto de la práctica artística, la relación tema y discurso, o dirección proyectual y sentidos enunciativos, casi siempre constituye un problema; la subordinación de una cosa a la otra, de un minúsculo hallazgo, digamos que formal, a una disposición de tipo temática, o del espléndido tema a una estructura a priori definida como una poética legítima, deviene, pues conocimiento y saber establecen un divorcio inmediato, no en una disolución unitaria, no 
en ese "a tiro de ballesta" que proclama Lezama, en LA CANTIDAD HECHIZADA, sino en una superposición dislocativa (forzada) de niveles cuasi desconocidos entre sí, y por tanto, en una cosa como opositora de la otra. Podría, en este sentido, refiriéndome a los dos primeros niveles (la serie sobre lienzo y la instalación mencionada), hablarse de entidades cuyas construcciones se sustentan, sobre todo, en la simbolización de otras entidades extraídas de unos contextos rápidamente recordable, por ello, de una posesión identificadora -tal vez, utilizadas como un recurso para la reafirmación del cuerpo temático, cosa esta dada en las prácticas abiertamente contenidistas-, que más que reforzar sus funciones enunciativas, las diluyen como extracciones, puesto que lo que se supone (o propone) como descubrimiento o poética práctica, produce un choque entre lo que es, sin más, una vieja experiencia y lo que podría legítimamente ser un nuevo precepto: porque esas extracciones me obligan al repaso pronto de un pasado iconográfico tan consolidado como ciertamente histórico. En DE ESTE LADO DEL PUENTE, piezas como "Meditación sobre el resguardo y la gozadera" y "Meditación beisbolera", definen, según mi parecer, el tercer nivel, el estrato primario, duro y, tal vez, más simple de todas esas miradas que pretenden dar cuerpo a la exposición. "De un complejo estructural -con el que en algunos casos hasta de modo desenfadado- se arma la obra", nos habla Esterio Segura en uno de los textos contenidos en el catálogo que acompaña la muestra, y sin querer minimiza el elemento (tal vez, el gesto) más poderoso en el juego de sus relaciones: el desenfado irónico de sus hibridaciones y los redescubrimientos temporales y temáticamente privativos. Digo minimiza, en tanto que, a medida que se empeña más en conceptuar las captaciones gestuales y su estructuración, abandona de súbito la presteza ligera de la evocación rápida -simple por poética, e irónica por cortante-, en pro de una racionalidad periodísticamente práctica, que dicho a la ligera, es cosa de gavetas y de archivaciones temporales. "Meditación sobre el resguardo y la gozadera" y "Meditación beisbolera", son obras que se complementan a través de un simple acto de reelaboración simbólica: por un lado, la figura de Buda (religión o filosofía, tal vez de ahí el dilema interpretativo del referente fetichizado y de su ausencia lógica) es protección y protegida, y por ello 
tal vez descansa inaprensible en una almohada cultural, tan occidental como ávida de definiciones, como lo es la caribeña y cubana (quizá en ella queda ilustrada la parábola de aquel hombre que habría de negarse a ser curado, no sin antes saber el nombre de quién lo había herido, no sin antes saber a que familia pertenecía, y de que madera estaba hecho el arco que disparó la flecha que lo había herido, y que al final moriría); y por otro, la imagen, también de Buda -quizá asumida como especulación mística, como sobrevaloración de la posible eternidad de los poderes y de sus ordenanzas, del alejamiento teórico de la vida inmediata y de la praxis del hombre corriente: que goza, sufre, asume o maldice, un estar caricaturizado y, aunque doloroso, carnavalesco de ausencias-, que sustituye, se desdobla o deviene, en una especie de elegguá ${ }^{10}$, que abre y cierra los caminos, o bien, permite o prohíbe el gran ajiaco nacional: el alboroto y la ética, el alambique y la Heineken, y el militante, el bocú y las prostitutas más sanas, según alguien dijo, de todo el universo (tanto el Buda como el elefante, cumplen la misma función en el entorno hogareño cubano, hacen de Elegguá sustitutorio). Es DE ESTE LADO DEL PUENTE, sin duda alguna, un juego expositivo, dentro de un engranaje de niveles, cuya proximidad y anclajes definitivos ha quedado, claro está -en tanto, hoy por hoy, esa aproximación es también una utopía, un recurso de huida y una sustitución (aunque poética) primeramente práctica-, sólo como un ligero guiño y (quizá como un piropo dicho a una multitud de obinilewa(s) ${ }^{11}$, como diría un Iyawó, ${ }^{12}$ ) una rápida insinuación.

1o ELEGGUÁ: Orisha primero en el panteón de la santeria cubana y la Regla de Ifá. Tiene dado, a través de Olofi, el privilegio de ser el primer Santo a quien se saluda y canta en una ceremonia. Aunque travieso, es el dueño de todos los caminos, y los abre y cierra a su antojo.

11 OBINIWA: Mujer bella, según la regla lucumí, de la santería cubana.

12 IYAWÓ: Iniciado. En los rituales de la Santería, persona que viste de blanco durante un año, como proceso de purificación tras su iniciación como santero. 


\section{A.9 EL REPRODUCTOR}

De entre esas tantas cosas que en más de veinte años han sucedido en la Facultad de Artes Plásticas del Instituto Superior de Arte de la Habana: Graduaciones múltiples, al estilo de cualquier otro centro universitario, del que han egresado lo mismo jóvenes de talento probado como también con una absoluta e irreversible desorientación; la coincidencia temporal "empeñados en un claro activismo pedagógico sobre la enseñanza del arte", de los más importantes intelectuales y figuras del quehacer plástico cubano (ORLANDO SUÁREZ, ADIGIO BENÍTEZ, PILAR FERNÁNDEZ, NELSON DOMÍNGUEZ, LUIS ORLANDO TAJONERA, FLAVIO GARCIANDIA, GUADALUOE ALVAREZ, CONSUELO CASTAÑEDA, EDUARDO PONJUAN, GUSTAVO ACOSTA, JOSÉ FRANCO, RENÉ FRANCISCO, LAZARO SAAVEDRA, MAGDALENA CAMPOS); las visitas de personajes de celebridad notoria y por ello distinguidas; los cursos de verano, orientados básicamente a estudiantes extranjeros; las becas de intercambio de alumnos y profesores con otros centros y universidades; las muchas deserciones de última hora, o anunciadas "quedadas"; las ventas y reventas, solapadas o consentidas, de obras y de las que casi llegaron a serlo: de las casi-obras; la puesta en práctica de renovadores proyectos de participación pedagógica; la construcción apresurada de una visión histórica y trascendente, aún cuando la inmediatez todavía no llegaba a rozar las puntas de las narices; el desvanecimiento de mas de una seudo-práctica, a priori entendida como discurso; las excelentes exposiciones, como alguna que otra de SEGUNDO PLANES o la del GRUPO PURÉ; los intensos y largos juegos de béisbol, en los que RAMÓN DUPORTE MATUTE, POZUMA O AGNER DOMíGUEz, eran figuras claves; la fundición y ensamblaje de la estatua de Antonio Maceo, bautizada como "el Maceo de Quintanilla"; los comentarios mañaneros, y siempre de distinta boca, acerca de los amoríos rápidos y casi nunca repetidos, con aquella bondadosa pinareña, a la que por cariño y resuelta fama, le decíamos "la Brocha"; las poco serias prácticas de Konfú o Kárate, asesoradas por un fagotista nicaragüense, aunque de origen alemán; las fiestas junto a fuente del patio central, en absoluta oscuridad, a las que con más de una intención se invitaba prioritariamente a las 
estudiantes de ballet y danza; las carreras en desbandadas para ver a Lili Rentería tomar sus baños de sol en la piscina del edificio de rectorado; los talleres de crítica y las ávidas defensas de cuanto ejercicio de clase fuera posible defender; la llegada al instituto, venidos desde Holguín, de ALEJANDRO AGUILERA y ROVALDO RODRÍGUEZ, trayendo como armas las influencias de profesores como COSME PROENSA, MONTERO o PARRA; la revista ALBUR, cuya artesanía y hechura jamás minimizó el carácter de foro inquietante y polémico de las plataformas teóricas y discursivas que por entonces cobijó en sus páginas; o la conga, dirigida al estilo santiaguero por RAúl EMMANuel (Pozuma), quien en uso de eso que llamamos propiedad intelectual o derecho de autor, y como un homenaje legítimo al grupo salsero japonés, la nombró "Tokio Cubans Pozuma", y un larguísimo etc... hay una, de carácter reciente, cuyo antecedente más próximo, quizá el único, lo encontramos en la revista ALBUR, y que de sobras ha llamado mi atención, no sólo por su importancia como documento que acredita el estado y dirección del pensamiento que se cuece entre profesores y alumnos en la interioridad del Instituto, sino por lo que significa como vehículo divulgativo "no sólo tras las interminables verjas de la institución, sino también nacional e internacionalmente", de la diversidad, contemporaneidad y riqueza, que define las nuevas prácticas visuales en el panorama cubano. Me refiero a dos publicaciones desarrolladas íntegramente en el Instituto Superior de Arte: la revista cúpulas, una publicación trimestral dirigida por Pedro Ángel González, perfilada como una mirada amplificadora del entorno cultural e histórico cubano, que tras un significativo cambio de formato y diseño, ha continuado su andada con la puesta en circulación, y en conjuntos, de los números 11 y 12; y la revista ENEM@, publicada por la Facultad de Artes Plásticas y bajo el control, casi férreo, de los propios estudiante de la facultad. ENEM@, que anda ya por el $\mathrm{N}^{o} 4$, toma su nombre, incluso su dinámica y espíritu, del colectivo-proyecto, desarrollado y dirigido como plataforma pedagógica alternativa por Lázaro Saavedra, "un notable de los ochenta..." "como dice Ramón Cabrera, en su reseña referida a la actividad y prácticas del real colectivo ENEM@, publicada en la edición $\mathrm{N}^{\circ}$, antes mencionada" , y desde esa dinámica, espíritu, y hasta cierto punto irreverencia y alternatividad, 
diseña sus estrategias editoriales como problematizaciones "si así se quiere, pues su trazado ironiza, desmonta y descoloca estándares", que involucran, como cómplices sorprendidos en ese hacer contributivo, a duchos, oficiosos, pseudos, y hasta doctores. Es, sin embargo, de la revista ENEM@, específicamente del $\mathrm{N}^{\mathrm{o}} 4$, y de la publicación en ella de una extensa obra de Duvier del Dago, "integrante del grupo Dupp (Desde una pragmática pedagógica), dirigido siempre por el profesor René Francisco", que quiero centren su atención, pero no preferentemente desde mí ejercicio divagativo, sino a través de la lectura de un texto escrito "leído de propia voz y para nosotros, allá, en su oficina de La Habana", por Jorge Fernández, bajo el titulo de "el REPRODUCtoR", que a continuación les presento. EL REPRODUCTOR (Un texto de Jorge Fernández, leído en el Instituto Superior de Arte en su intervención en la defensa de la tesis de grado de Duvier del Dago) En uno de esos días en que me encontraba agobiado por el calor y por todos los rollos institucionales que me toca resolver, al llegar a mi oficina encontré entre periódicos y cartones un personaje que aunque al principio lo miré con cierto desdén, luego me dejó millones de interrogantes, instándome al diálogo con él. Inmediatamente después pensé ¿Cuantas horas de lectura pude haberme ahorrado, si hubiera conocido antes al Reproductor?

Luego vino mi encuentro con Duvier que se presenta como una suerte de interlocutor del Reproductor. De momento sufrí una gran confusión, no sabía cuál era el verdadero artista y cual era el falso. Rápidamente diseño una estrategia, debía apertrecharme con bastante información para poder atacar y salir con vida, al instante no vacilé en echarle mano a las Estrategias Fatales y la Seducción, de Jean Baudrillard, Un diálogo sobre el poder, de Michel Foucault, Después del fin del arte, de Arthur Dando, La Seducción, de Severo Sarduy, La diseminación, de Jacques Derrida, Originalidad y Mitos en las Vanguardias, de Rossalin Krauss, y por supuesto uno que no podía faltar "Mi filosofía de la A a la B", de Andy Warhol. Todos estos títulos formaban en mi mesa una suerte de columna infinita al estilo de Brancusi. Mis contrincantes, quedaron impresionados, más cuando les dije que esas eran las principales 
referencias para las preguntas que debe hacer la oponencia. Sin embargo, fue la archiconocida canción de la Lupe, tan difundida por Pedro Almodóvar, la que me abrió los caminos con ese famoso estribillo "lo tuyo es puro teatro, falsedad bien ensayada, estudiado simulacro". El Reproductor dignifica la autenticidad del comics y la historieta para adentrarnos en los problemas del arte contemporáneo. La realidad y la representación coexisten sin diferencias. Las experiencias son borradas porque el mundo contextual ha desaparecido. La cosa se ha convertido en la imagen que proyectamos de ella. El sujeto y el objeto se disuelven como en las ediciones on-line de formato digital. El Reproductor permite una visualidad matizada por la cúpula de información que habitamos, en él están presentes los nuevos estandars, donde se jerarquizan los significados. Ya no se trata de encontrarnos, como en los tiempos de Walter Benjamin, un artista productor. El autor adopta la forma del ventrílocuo, no produce símbolos porque el mismo es el símbolo. El ser y el estar se expresan en su reversibilidad para mostrar la imposibilidad de un corpus sustancial, pertenecen al reino de lo inasible. Ya no es necesario internarse en una sala oscura ni activar un proyector de $35 \mathrm{~mm}$. Desde cualquier habitación doméstica se puede percibir el mundo "reír y vivir, como cualquier estrella de televisión, es un fenómeno cotidiano. La cultura, como en los andamiajes de los cubos de Sol Le Witt, cambia de acuerdo con las necesidades de los públicos, aspectos que están transformando los modelos culturales. Para muchos estudiosos, el concepto de nación puede analizarse como pactos de lecturas, y sus integrantes como comunidades hermenéuticas de consumidores. Cada día la información y el conocimiento se dosifican y se amplían en forma de malla extensible, las cosas hay que decirlas rápidas, claras, y sin ningún tipo de complejidad intelectual. Todos quisiéramos modelar para las estatuas del reproductor, obtener aunque sea un instante de celebridad. Sentir una subjetividad que transcurre a partir del intimismo simulador, obsesionado por los aires de la notoriedad. ¿Qué emocionante cuando algún amigo te dice "Te vi en la televisión", sólo que, en ese mismo instante, descubres que la aparición azarosa ante las cámaras develó la invisibilidad en que habías vivido hasta ese momento! Para el Reproductor la representación es lo hiperbólico, sólo se alcanza desde 
la transexualidad, él no es mujer ni hombre es sólo la apariencia de algo que no es real, lo que permite ser un cuerpo desde la misma superficie, la mascarada más tangencial. El trasvestismo es sólo la mejor opción para plantear las mutaciones más radicales y constatar "desde esta imagen" la opacidad del simulacro como los personajes Letal, de Pedro Almodóvar, y Joe Dallesandro, de Andy Warhol; pero prefiero, ahora, que el Reproductor me permita la celebridad que reclamaba haciéndole otra entrevista televisiva. 
A.1O EN TORNO A LA ILUSORIEDAD: CINCO MANERAS DEL VER POSIBLE

Los vivientes, nosotros —entidades de actividad constitutiva-, aposentados en ese, (éste) "entre" de serialismo mass-mediático que suponen las intensas transformaciones científico-técnicas, parecemos no estar conmocionados ante el filoso desequilibrio que, ya mismo, nos ha convertido en heridas, en figuras sin rostros y de ademanes falsos, en cuerpos sangrantes decapitados de subjetividad y utopía; parecemos no atisbar el progresivo deterioro de los modos de vida individuales y colectivos, la relación de vecindad reducida a la nada, cual novelada ceguera - teatral oscuridad-, hecha propia para olvidar al otro. Ya los ojos no miran, pues parecen no poder ver. La aprehensión de estímulos, la relación de la subjetividad con su exterioridad inmediata, aún siendo básica ésta condición del viviente, su función propia, redunda en el mismo sentir y viaje - dígase, ausencia de diferenciación de la estimulación, ausencia, entonces, de esa clandestinidad que estimula-, hacia, y ante, los mismos comportamientos resolutivos de la imagen que del "entre" se tiene, y por tanto, pretende representar.

Con matices, quizá como entredicho, cual cauta incitación al necesario volver a la autoposesión de la realidad propiamente dicha (suplantada por el igual ideal de standing) y a su reconstitutividad — pues al menos, entidades de esa actividad parece que somos-, los cinco proyectos albergados hasta hace unos pocos días en la Galería Luis Adelantado (Sala 1, Juan González; Sala 2, Bene Bergado; Sala 3, Joan Morey; Sala 4, Priscilla Monge; Sala 5, Omar Ureña) aludían de un modo u otro al problema de la ilusoriedad como sustitución macabra de la estimulación, como antifaz carnavalesco devenido de la estandarización de los usos (de su institucionalización corporativa), ante la atención inteligente, el gesto simple e individualizado, la complicidad y lo intimo, la poética pública y la mixtura diversa (a pie de barrio), y la contrapartida necesaria del ver posible y del decir concreto a otros niveles, con distinto sentido $\mathrm{y}$ en otras direcciones.

En uno u otro caso, pasiva o activamente, la reclusión de lo histórico 
como entredicho: antecesor y antecedente secundarizados, el dato que retrotrae asomándose rápido y luego enmascarándose - el uso temático del cuerpo (OMAR UREÑA, Sala 5) como pretensión analítica de la fetichización de la mirada urbana (si es que la hay) en torno a la figura del superhéroe y su connotación sexocultural: goce y dolor; el intexto marketinizado (JOAN MOREY, Sala 3), la mise en abyme, dicho cinematográficamente, moda(s) en la moda, imagen(es) en la imagen, música(s) en la música, y publicidad(es) en la publicidad como base utilitaria y reflexiva del sí mismo, del yo-imagen como posibilidad evidente de estandarización y objetivación de la envoltura corporal como criterio: ¿Soy como me proyecto ser? ¿Mi imagen y actitud guardan correspondencia con esa que se nos da como real? ¿Soy fetiche por fuera y humano por dentro?, tal vez incita a que nos preguntemos; crítica (PRISILla MONGE Sala 4), pues la fuente histórico-artística Latinoamérica, versada en la unidad entre discurso artístico y compromiso sociopolítico, es su firme de edificación, enfatiza, fría por real denuncia e hiriente en su instancia poética, en la escenificación de un panorama cultural autocomplaciente, vulgarizado, y presto a la mimesis y vestidura de la indiferencia; la sucesividad antropoligizada (JUAN GONZÁLEZ, Sala 1) y visionamiento de los lugares de desencuentro, de significación o distinción del tipo social o la clase por tanto del no-dialogo, de norelación; las fantasías e hibridaciones (BENE BERGADO, Sala 2), como ofrecimientos electivo y democratizantes hacia el espectador ("tratan, dice, un abanico de cuestiones lo suficientemente amplio para que el espectador elija entre una lectura más fantástica e irreal y otra lectura más abierta a interpretaciones subjetivas que tienen como telón de fondo algunas de las relaciones que establecemos con nuestro propio entorno"), cual si la esencia del viviente, el ser individuo constitutivo, no denotara por sí mismo el carácter de selectividad de lo elegido-; sin embargo y paradójicamente, esa reclusión en lo historizado, el asomarse rápido y enmascaramiento tácito, parece haberse entendido como igualdad posible o entidad de posibilidades, como hitos avistadores de una cierta clandestinidad que habría de devenir en estimulación, en decires irreverentes recuperadores de la perdida utopía, o en su caso, un modo cambiado de aprehensión de las cosas que a pesar de su aparente 
insignificancia redundaría, cual cambio esencial, en la transformación del carácter de la estimulación social. Dijo un sabio una vez -plenas sus palabras de la agudeza que sólo la vejez le había otorgado y con el filo irónico que sólo los muchos años habían convertido en rejuvenecimiento- refiriéndose a los modos de atemperamento de la realidad, que querer, desde luego, distaba en demasía de inteligir, pero además, con sentencioso desborde, que ni una cosa ni la otra ello constituían, sino meros, y como tales, momentos especificantes. 


\section{A.II EXTRAÑO CUERPO DE COLOR}

"Guiada por la curiosidad sobre ciertas "identidades perturbadas", este cuerpo se convertía así en un lugar idóneo para investigar sobre la fragilidad del sujeto contemporáneo frente a determinadas situaciones y las repercusiones que pueden tener éstas sobre su experiencia", comenta Begoña Montalbán en la nota de presentación de su exposición INTERIOREs en la Galería Tomas March de Valencia. Primero fueron alusiones al cuerpo femenino: inquietantes fragmentaciones de su figura-arquetipo e impávida objetualización del fragmento a devenir en supuesto utilitario y de placer; luego, reparos en torno al cuerpo del maniquí femenino (usado como alegoría, ejercicio de auto-conocimiento, fragmentos de memoria, etc.), visualizados en la serie "Sujetos", crecida e insertada en exposiciones como "sUJETO" A LO INEFABLE (Galería Antonio de Barnola, 1994), "sujetos" (CAZ. La galería, 1994) o "APUNTes para UN Diagnóstico" (Galería Tomas March, 1996). En aquellas primeras alusiones (fragmentaciones alarmantes), como en "APUNTES PARA UN DIAGNóstico", el trozo extraído y re-figurado era despojado de la temperatura humana e investido, en su alojarse nuevo -en esa apariencia de objeto evocador de fruiciones y de gozo, de pensamiento alterador de la huella-recuerdo o de presencia centrada en la corporeidad de donde es proveniente-, de una cuantía insinuatoria que, invirtiendo el cono de su visionamiento, sustituía, cual reto propicio, el posesivo retrato (y mirada) de lo ideado como única feminidad por la emanación jubilosa - y propensión- de un "otro poetizado", y tal ves, en tanto que hendidura sujeta al devaneo de la sapiencia, por la vitrina hechizada del gusto por lo concupiscible $\mathrm{o}$, si se quiere, por la delectación de ver (escudriñar) imaginando lo "carnal-perturbado" tocado por la gracia. Antes que una revelación contundente sobre los estados de identificación del cuerpo o propensa orientación de la mirada y la idea, incluso, antes que naturaleza interferida (y pugnante) por otra naturalidad, e igual, antes que escondrijo, el término identidades perturbadas, esa acotación que intenta y da impulso a un sublime planeo representacional por la fragilidad del sujeto, se me antoja pensarlo 'filoso', cuerpo de picaresca fina 
que encumbrado, y sublimando por igual una atención pretendida clínica y otra de caracterización sociológica, deviene (ha devenido) en traviesa sonrisa y guiño, si no de aceptación definitiva, por lo menos de una complicidad continuada y de una plenitud nada frívola. Ya desde ESPACIOS RESERVADOS y hasta ahora mismo, en INTERIORES, esas identidades perturbadas, esos iris-pretextos, ondulan, cual eficaces fantasmas aferrados a la vieja tarea y pretensión de insinuarse energías, incluso, aunque a veces para nada hayan contado, como resortes de una comprensiva visión (sólo inicial y de puesta en marcha) de la figura del maniquí femenino como la entidad ideal para esas inmersiones poéticas en un ámbito - $\tan$ complejo, como improbable-, como el de la fragilidad del sujeto. Tal vez como ocurre en INTERIORES, quizás haya sucedido en ESPACIOS RESERVADOS: que de esas a veces inmensas fotografías o sublimados registros, aparente tirar (siempre y más), jalonar hacia sí, una dimensión visible, y por tanto figurativa y pendiente del límite temático, que un sentido elevado de lo legible y enunciativo; en todo caso, esa distancia distintiva entre la dimensión visible (representacional) y el sentido legible (enunciativo), de estar precisada, seria a la vez el lugar de una oposición y de una fluctuación constante entre lo atribuible bien a la dimensión, bien al sentido, y resolvería, como casi ha quedado resuelto en INTERIOREs, ese viejo conflicto -más de una vez metodológico-, entre la orientación discursiva (intencionalidad teórica, enunciado, sentido) y la estructuración práctica (tema, forma, espacialidad) y visual de la obra. En INTERIOREs, las alusiones al doble figurativo del que habla Begoña —unas veces fantasma o máscara, otras, el otro-yo o el yo-otros-, en tanto que detenciones fugaces de signos y símbolos perseguidos, además de lo que ella sugiere (en el término clásico de la escultura, la figura humana), habría que entenderlas (en los registros-resultantes y en su reconversión en entidades fantasmagórica) si no como una supresión de la cualidad y la esencia del cuerpo -cualidades y esencias que no son nuevas pues flotan como arquetipos repetitivos de un cuerpo dado a alcanzar dimensiones de analogía一, por lo menos como la congelación del nivel más crítico de enfrentamiento entre el fantasma presente (re-figurado) y el cuerpo pasado (memoria), entre el maniquí y lo humano, entre la máscara y su rostro. Así, 
de esa congelación, pensada entonces como inquietante, obsérvese el transcurrir de la relación establecida entre el maniquí y el cuerpo, en la que el maniquí es el que fluye, cual si fuera diversa cualidad, mientras que el cuerpo, que si lo es, se fija concepto arquetípico (para siempre) en la lejanía; distíngase una transfiguración de la imagen de lo femenino (el cuerpo) en una memoria reconstruida del maniquí, y luego, en el registro fantasmagórico de sí (manipulaciones fotográficas), donde la imagen - en su estricta condición de registro, en su concentración novedosaes, evidentemente, la resolución acabada de una finísima artesanalidad, y no, como puede llegar a pensarse, un signo detenido. 


\section{A.12 FILO FINO: EXPOSICIÓN DE JORGE LUIS H. POUYO}

"En efecto, la poesía es un peligro, y su engendrador, el poeta, de alguna manera es siempre proclive a dos abismos. El primero se entroniza cuando alguien lee sus textos; el segundo es la hipotética indiferencia en relación con sus alaridos; mas ello no excluye la gran verdad de que lo poético es invulnerable al acercamiento o la distancia de sus inagotables enunciados". ${ }^{13}$ Marino Wilson Jay

Nivel 1: Simple, una aproximación a la idea de pintura... De las aproximaciones teóricas que en torno a la pintura han caído en mis manos, siento un especial cariño por la que Cennino Cennini (1350/60¿?) -discípulo de Agnolo Gaddi, hijo y discípulo de Tadeo Gaddi, ahijado y discípulo de Giotto-, formuló en LIBRo DE ARTE, la única de sus obras, tanto literarias como pictóricas, que hasta hoy a llegado, no sólo por esas cosas del don divino, sino porque fue lo mejor que dio de sí. Cennino Cennini refiriéndose a las técnicas del arte, dice respecto a la pintura: "Y hay un arte, llamado pintura, que requiere a la vez imaginación y trabajo manual; porque el pintor ha de inventar cosas que no se ven, representándolas con la forma de las cosas naturales y modeladas con su mano, haciendo que lo que no existe parezca existir"14. De simple, si la simplicidad es entendida como la dimensión fundamental y no contaminada de la cosa, podría calificarse su noción de pintura, ¿verdad?, pues al menos en esa relación (imaginación-manualidad), supeditada a la época, queda resuelto el todo pictórico; pero por igual, y con arreglo a su particularidad histórica y genealogía, la clasificación permisible sería la de primitiva, y por tanto -desterrando cualquier exabrupto e ingenuidad-, de básica y rigurosamente imprescindible, en el intento de entendimiento de la pintura como una actividad discursiva, y en ultima instancia - cosa que me gusta menos, más bien poco-, como vehículo de expresión. Nivel 2: Relación-condición, simplicidad... A la pregunta de qué relación guarda la definición que Cennino Cennini hace del arte de la pintura y la obra,

13 Wilson Jay, M. Peligro: Aquí se habla de poesía, Ed. Oriente, Santiago de Cuba, 200.

14 Cennini, C. Libro del arte, Ediciones Ital, Roma, 1974. 
como tal, de Jorge Pouyu, la respuesta es "una relación de figura y una distinción de simplicidad. Contrariamente a lo que en apariencia sugiere - tema, gestualidad, dimensiones, mezclas-, el conjunto de la obra producida por J. Pouyu, está asentada solamente en tres elementos discursivos: el primero tiene que ver con una cierta la amplificación graficada del gesto plástico; el segundo, con una irreverente poética del color; y el tercero, con un carácter enunciativo incuestionable crítico. De sus obras y proyectos, el valor de artisticidad ha de entenderse no sólo como derivativo de un esfuerzo ávido (consecuente y coherente) entorno a un trazado de conocimiento de la pintura, a un saber especificado como problema, que ha pretendido - desde su inicial configuraciónsubvertir, desmontar, solucionar o sublimizar, un ámbito concreto de lo real vivido o lo real que entonces vive, sino también como complementario y en rigurosa oposición a los estándares folclorizados, los localismos vacuos y las artesanalizaciones convenientes (reducción pronta de un discurso posible a su caricaturización etno-comercial y oficiosa) que desde la infelicidad intentan pulular en ese territorio dado únicamente, y fertilizado, a la poéica discursividad y las más legitimas acciones de culturalidad.

Nivel 3: De la exposición evidente a la "exposición imaginaria"15: cuatro evidencias en Motivos reales. Evidencia I. Las exhibiciones artísticas exigen de unas especiales condiciones de excelencia que a su vez han de implicar una definición singularizada de la idea de calidad y valor, lo cual configura, siendo ese su fin primordial, una imagen del sentido de la vida y de la identidad de quien ejerza el papel de espectador. $\mathrm{O}$ el espectador da fe de esa concepción o la niega, decidiendo respectivamente la condición de estar dentro o fuera del conjunto que privilegia a los iniciados. Por ello es que muchos se sienten agradecidos por el arte que no les gusta: por que les empuja fuera de la comunidad, les convierte en presa. Evidencia II. Una obra, o un conjunto de ellas, puede en apariencia no significar nada, y sin embargo, al margen de esa condición de ilusoriedad, estar codificada

15 Expresión usada por Thomas McEvilley en el texto "Exposiciones-reales e imaginarias"," publicado en falta nombre de la publicación Ed. Institut Valencia de la Juventut, 1991. 
sutilmente, como también, complementada por otras cuyos códigos pueden que sean asumidos como significativos por el espectador, y por igual, en otra dirección, ignorados por su autor, no por la carencia de un saber especificados sobre ellos, sino por la abstracción limitativa que supone engendrarlas. Evidencia III. "MOtivos REALEs". En tanto es una exposición imaginaria sugiere unas ideales características de lo humanorelacionado, una versión que implica una concepción diferenciada de la naturaleza de su entorno y de quienes, por tanto, en el actúan. En tanto lo es, se ofrece como "distinta", pues ha de lanzarse como contravención no sólo de la sobrada expectativa que sobre ella se cierne, sino - y de ahí la naturaleza de su hondura- como la más tajante inobediencia a toda una discursividad de sobra asentada y a un modelo de formas plásticas, que ha de quedar ceñido a la memoria, el coleccionismo y el buen gusto por las acción rebeldes. Evidencia IV. Los tiempos han cambiado y las ideas también. "MOTIVOS REALES" es una prueba del cambio espiritual de la época, pero no sólo eso, sino que contiene además una cierta energía vivificadora que actúa (ha de actuar) como amplificadora de esa espiritualidad que refleja. Motivos reales y sobrados no sólo ha tenido Pouyu para esta, dada por iniciada, emprendida, sino, cosa más saludable, conciencia clara del cambio que inevitablemente se nos viene encima. 


\section{A.13 LA PARED DE CRISTAL DE DORA GARCía: ACCIÓN \& PROPÓSITO}

"Dora García es una artista española, y eso es evidente si se mira su carne de identidad, se conoce su procedencia vallisoletana, sus raíces, su familia, si se sabe dónde vivió y realizó sus estudios". Margarita Aizpuru De las actuales prácticas visuales en España, uno de sus problemas, quizá el más grave, toma desmesurado cuerpo en la casi nula vocación de acercamiento, de hondura ávida y audaz, hacia las zonas esencialmente problemáticas y básicas, figuradas en la raíz misma de su natural diversidad. "La premura y las anticipaciones — se dice en América- están al día y marcan las horas no porque sean acotaciones temporales, sino por sus determinaciones efectivas". En esa brecha, en la articulación de las nuevas prácticas visuales, virtualidad parece haberse entendido como sentido pronto y naturaleza de ellas; el medio, como sustituto apresurado del fin, de lo definitivo para ser y por ser establecido; y el desborde temático (dígase, entendido como contenido inevitable, y no como centro de conocimiento problémico), como el encadenado definitivo —abocador a fuerza de eslabonazos y cristalizaciones esporádicas, e incompletasy rostro de clarificación, por parentesco y sutilezas aproximativas, de eso que debería entenderse como la tesis posible. En la raíz primaria de estas actuales prácticas parece tener alojamiento no sólo una incompleta comprensión de la experiencia de la modernidad —en tanto dimensionamiento cimero del significado y la noción de identidad permanente, y a su vez, revolucionaria aventura del vivir paradójico (de la paradoja), lo contradictorio y la ironía- como antecedente seguro, sino también, demasiado a menudo, una desfigurada asimilación del ideario posmoderno (de la pluralidad cambiante tanto del individuo como de la historia, que ni tienen una identidad fija ni van en una dirección determinada, en oposición a la noción moderna de progreso, de puntos de referencia y de jerarquía), cuya silueta, entonces visionada y aprehendida desde la simplisidad de juicios apropiatorios e institutivos, ha ido adquiriendo, tal vez desde los ojos de inexpertos falsarios, una dimensión de figura de la experiencia 
que transcurre así mismo como episodio subversivo, como digresión de alteraciones (no porque los transgrede, sino porque los minimiza) de los ordenes de "discursividad imaginaria", de los márgenes de articulaciones enunciativas y los entornos de asentamientos prácticos, siempre determinados como zonas de especificación de la artisticidad, y no como en principio debería ser: como espacios para lo esencialmente humano o para evitar los adsolutismos de la presencia como los de la ausencia; adquisición y figura, toda ella, constituída sobre todo al tornarse no un radical replanteo de la situación y relación respecto a la nueva idea de mundo, la idea de diferencia o no-diferencia que se tiene de sí en éste momento, y la idea de sí que se tendrá en otro, sino una re-posesión cristalizada en la superficie acuosa de la nostalgia (otra vez más el sueño de la brújula tribal), el parecerse (la cita como rostro ágil del/ y para el reconocimiento), y la mimesis, cual fondo de armario repleto, y clave, para ese más que esperado abrazo institucional. En esa zona inconsistente de las producciones visuales actuales, y sólo en ella, encajaría el encabezado al que recurro, puesto que el supuesto lo evidencia, y en tanto que, pretendiendo introducir un decir, augura un desdecir lúgubre en torno a la mezcla, comportamientos y sentido, de la obra de una de las artistas con más caché y severidad discursiva - parte de ese bragado grupo de hacedoras que, entre otras, forman Montserrat Soto, Mabel Palacín, Ana Navarrete, Salomé Cuesta, Eulália Valldosera o Begoña Montalbán- como lo es Dora García. "Insertos en tiempo real", y de ahí "LA PARED DE CRISTAL", tiene mucho que ver con eso que Thomas McEvilley alguna vez ha llamado "exposición imaginaria", pues sugiere, quizá intenta definirse - y aquí lo parafraseo- como territorio fértil en el que pueden, deben, y tienen cabida, propuestas sobre la esencia de lo humano.

El website Insertos en tiempo real (http://aleph-art.org/insertos/), es el punto de partida y a la vez el centro de recepción continuada, para la memorización y el relato, no sólo de La pared de cristal, inicialmente realizada en Utrech como parte de la exposición "House of games", sino también de Proxy (visionado en Arco 2001), y de ocho proyectos más que en principio lo completarían. Pensado como 
ventana de seguimiento, de información pormenorizada, visual y textual, del transcurrir performático 'en tiempo real', da alojamiento cronológico, cual informes noticiosos, si no de cada elemento, pues ello superaría contradictoriamente el rasero poético (incluso de la imagen) de "Todas Las Historias", por lo menos de las esencias conversacionales, ordenativas y versionadas, de lo que tras la literalidad de cada proyecto acontece. Es allí, en el site "Insertos", donde con más objetividad, tanto poética como práctica, se puede encontrar y entender el sentido legítimo de una propuesta como LA PARED DE CRISTAL, ahora expuesta en la Sala La Gallera de Valencia, y las huellas que como versión le anteceden. LA PARED DE CRISTAL de Dora García, siendo título y proyecto, establece - más que la visión misma de un acto de problematización, más que la puesta en ojos de todos de las preguntas mismas que dan curso a su fin ideal—, el génesis de un símil cuyas aristas emotivas descansan en el drama, y como obviedad, en el peligroso y necesario asomarse que como empresa posible de realización ello supondría. Siendo título, proyecto o entidad poética -acotación de nadie, podría decirse-, transcurre dimensionándose, volviéndose constante abertura de sí y para sí descubriéndose, cual único sentido que la define. Sin embargo, siendo actividad performática (referido éste a las adecuaciones necesitadas para su versión expuesta en $\mathrm{La}$ Gallera), recodo de memorias y retracciones, actividad de historización y teluricidad, desborda su estamental naturaleza en una naturalidad-otra, en un cuerpo de mediación abortiva, donde entonces el sentido declina en oscilación entre la literalidad y lo ineludible.

En esa dirección, el afán seductor, el pedagógico convencimiento, se re-funda en imagen-acción sensacional, en extendido signo de integraciones mediadas, cuyo conflicto primo, el haber sido pregunta y problema, deviene en disolución —así, en lejanía de lo inmediato cuestionable, de lo extraño-y en protos aparentes. Mientras que por un lado la actitud-LA PARED DE CRISTAL se disuelve en regiones ideales de lo performático: la doble contención del diálogo videografiado, el espacio de la actividad conteniéndose a sí mismo, tal vez ficcionándose, (si una de las performers ha ejecutado sus actos en un lugar distante, al 
menos el espacio desde donde las ordenanzas han sido pronunciadas debe quedar re-producido como garantía recíproca del diálogo), lo representacional como auxilio de lo presentacional, de lo que ocurre in situ aparentemente oculto ("Enter", la segunda performance presentada en La Gallera), lo histórico-referencial (recuérdese "Hors-champs", 1992, de Stan Douglas y su lógica conversacional videográfica) como instrumentación voraz de la memoria, o la imprevisibilidad cotidiana en oposición a la previsión artistizada del sujeto institutivo —quién ante ella instituye las pautas legítimas-; por otro, LA PARED DE CRISTALproyecto rescata, pues ahonda simple en esa búsqueda, un más que claro grado de objetividad, en tanto hace suya esa relación dinámica, ese ámbito de inter-actividad y transcurrir interpretativo - ilimitado pero accesible-, que se establece con el lector-practicante enfrentado al site: proyección y tesis constituyen un todo de recuperaciones problémicas al hacer descender a niveles de concreciones mundanas, de a pie accesibles, cuestiones propias de la naturaleza o los límites, si es que los hay, que acotan el ser o no de una entidad recluida en lo artístico.

“Dos mujeres, describe Dora García, se encuentran permanentemente conectadas por medio de un dispositivo electrónico que les permite intercambiar órdenes mutuamente"... Así descubre el primer secreto de la figuración performática; lo entrega como disolución de esa actituddistancia, de distinción —-condición artistizada/ condicionante cívico-, que, al menos teóricamente, hace de entidad interruptora, de separación problémica entre la acción emitente y la actividad remitente, que visiblemente ocupa su atención; lo entrega por tanto como indicación notoria y puerta de nadie abierta al flujo legítimo de soluciones e incertidumbres comprensivas: no se trata, plantea la entrega, de que se crea en la palabra y la acción como rigurosas construcciones de artisticidad sino como estamentos de interactividades efectivas, y afectivas, ante lo real cuestionado. Sin embargo, es en ese descubrir, en esa entrega anticipatoria, donde, según mi parecer, y de manera contraria al inicial propósito, queda acunado lo distintivo (la distinción) como reafirmación de sí, pues ha devenido entidad paradójica tras el intento de disolución: acción y propósitos han quedado marcados, 
diferenciados por tanto de la actitud-distancia, e igual, de todo lo demás. De la relación acción y propósito, éste último singulariza más que el primero - quizá porque le atribuye a la cosa una naturaleza a priori-, la incertidumbre.

"Dora García es una artista..." Sólo con esas cinco palabras, escritas y dichas en la rueda de prensa por la comisaria de La pared de cristal, he de quedarme pero con un añadido: ¡Claro está! 


\section{A.14 UN MÓVIL EN LA PATERA: LA PLUMA INEXACTA}

El mismo que talla el timón en tiempo de trabajo cuando se declara la guerra es el que talla la madera convirtiéndola en lanza: afortunadamente, quizá virtud, su actuar coherente en una situación $\mathrm{u}$ otra, consiste no tanto en que esas condicionantes puntuales que lo obligan a ello sean idóneas para ejercitar su oficio, sino que, incuestionablemente, ese hombre sabe tallar.

La tentativa de conceptualizar el diseño como actividad específica, de resolver ante la creciente industria el problema entonces planteado entre la utilitariedad del objeto y su cuerpo estético, del "abajo el arte, viva la técnica", o la orientación del fervor experimental en sentido de actividad práctica, de llevar el arte y su práctica a la vida, se torna insinuación insistente en la primera década del pasado siglo XX, y toma carácter de radicalidad cuando Rodchenko, en 1920, proclama el famoso Programa del grupo productivista; sin embargo, aún así, en cuanto la enunciación de su práctica es indicada a través de la palabra arte, por vincularse genérica y funcionalmente con su contenido, el término diseño todavía no es usado, prefiriéndose antes las denominaciones "arte industrial" y "construcción artística", derivadas al parecer del lenguaje constructivista que resolvían en parte el "gran experimento" de: en lugar de llevar el arte hacia la vida, se crearía culturalmente dentro de la vida misma. Fue la vanguardia rusa - los padres del diseño, por tanto-, la única entonces, en comprender la formulación hecha después por Harold Rosenberg: Durante más de un siglo los movimientos artísticos radicales han estado demandando le "desacralización" del arte y la disolución de todas las barreras entre el arte y la vida. Tales esfuerzos están destinados a fallar en tanto la palabra "arte" continúe refiriéndose a una categoría especial de objetos ${ }^{16}$. De aquellos planteamientos y actitudes sólo dos cosas nos diferencian: primero, el desborde técnico y mediático erigido condicionante límite de los usos y prácticas, y segundo, la no problematización de tal desborde, por tanto una más que complaciente imparcialidad ante

16 Rosenberg, H., The de-definitión of art, Chicago, The University of Chicago Press, 1983. 
el perfil que como estamentos absolutizadores de poderes los define. Sin embargo, esas dos diferencias parecen no ser, de conjunto, la distinción definitiva y legitima que nos aleja del fracaso eminente de cumplir con la función esclarecedora que por contemporaneidad nos corresponde en ésta 'comunidad de comunicaciones'; parecen no serlo - y aquí enfilo el sentido hacia la ordenación estratégica y enunciativa de lo mostrado en el EACC - en tanto el envoltorio supuesto, dicho "nueva forma de comunicación", o "visual", continua refiriéndose a objetos categóricamente especiales, por tanto de acotaciones artísticas. Referido, entonces, que bloquea descuidadamente el cuerpo o impronta comunicacional, devenida, de modelo de reciprocidad comunicativa, de transformación significativa de la subjetividad del opinar y del querer, en entidad ficticiamente normalizadora de enunciaciones pretendidas como legitimas representaciones de un universal. Lo presentado no siempre se erige en (y como) representatividad activa de lo que la literatura pretende conferir. Nada de premuras anticipatorias. ¡Hum! ¡Hum! ¡Hum!... no es la expresión de ningún pensamiento, y sí la guturización teatralizada, y reflejo, de un estado de incertidumbre creciente, y quizás, cosa más que triste, de peligrosa perversión. Pensemos - pues nuestros abuelos en estado de menos lujuria, cosas así nos legaron-, que la buena mirada del ojo quieto y paciente, es sólo con la aurora cuando hace suyo el conocimiento de la buena mañana, de su luminaria primera como certeza del transcurrir posible, y así del andar prudente e inequívoco.

La impronta técnica, tecnológica (tal vez de ella, la verborrea trasvasada, la sacralización del made in mimético, por igual de segunda mano, la cuasimetaimpronta porque simula ser o referirse a protos inexistentes), aprehendida (como si así fuera) en un tiempo supuesto real, y aprendida letra por letra massmediaticamente, no significa, no debería significarse -interpretarse significado o dárselo al hecho- necesariamente como marcha-designio único, o enfilado ciego, hacia el ajuste técnicoconstructivo de la producción de artículos hasta hoy resueltos desde una maquinal artesanía, o en tal caso, y más (pensando en los tres niveles de constitutividad en los que, desde éste mundo primero, 
se ha divido a un único conjunto de viva culturalidad) desde la literalidad de lo artesanal. Como propia, entiéndase, a cada situación técnica o desborde revolucionariamente tecnológico, le es recíproco un estado de artesanalidad —de principio oculto bajo la mística secreteada de su carácter estratégico: militar, político, científico o económico-, que concluye convirtiéndose, tras su colectivización progresiva y no "socialización", en contratecnología, y a ultranza, en sucedáneo mercantilizado y empobrecido (aunque necesitado) del inicial estamento que como superación universal le permite instituirse como posible. "El caracol viene, pero, ¿cuándo llegará?", afirma primero y luego nos siembra de dudas, un antiquísimo proverbio ruso, del que jamás, como evidencia el tiempo que corre, ninguna campaña publicitaria haría suyo como slogan; como menos lo harían, en letras gigantescas y tubos de neón o a través del más exigente sistema de efectos especiales, de ese otro del refranero tibetano, que dice, aún siendo milenario y cual si tajante se refiriera a la actualidad, que "los corderos tienen la gentileza de mamar de rodillas". De ingenuidad, así por tanto, debería calificarse cualquier esfuerzo comprensivo en torno a la santa relación difusiva tecnologíamassmedia, o diseño-comunicación, a la contenida tarea explicativa de hacer accesible (por práctico y estético) lo difundido, pues “... nunca implica - tal como afirma Gerardo Mosquera - una transformación (y añado, de índole solidariamente humana) a ese fin de lo difundido"17, por cuanto el destinatario global no constituye el criterio que rige su distinción conceptual. Nada nos ordena u obliga a olvidarnos de la pluma egipcia como símbolo de precisión para pesar las almas, ni que el recorrido del dardo hasta la diana, de la unidad dardo, es su sucesividad parabolizada y numerable, o de que en las letras figuradas en el tablero Ifá de la santería afroamericana, es legible lo mismo el nacimiento (bi) que la muerte (ikú). Criptizada, gaussianizada de palabra y figura -comunicación e información, expuestos y dispuestos como sinónimos de saber, modernidad, e incluso, imparcialidad-, la elementalidad técnica, su ser adecuativo común, gana territorios de alejamientos

17 Mosquera, G., El diseño se definió en Octubre. Ed. Arte y Literatura, Ciudad de la Habana, 1989. 
(pensado entonces, estrategia espacializadora, de desarraigo abrupto y pérdida de los vínculos primarios de valoración) ante el supuesto - pues por derivación, la retahíla y avalancha de nuevas herramientas técnicas nos abocan a ello-, de la comprensión de tal 'impronta' como el sentido de una práctica supratécnica establecida, por pretendida - la idea de diseño decidida como totalitarización posible-, como correspondiente, primero, con la época y dimensión de la idea de conocimiento que se cree de ella tenemos, y luego, como cultivo (o cultivadora) de unos nuevos productos, también de valor, cuya re-fundación y utilidad en apariencia la abarcan: el objeto tradicional, en posesión de una tipología (incluso estética) adaptable, es asumido por la nueva industria globalizante (y el término industria, hoy más que nunca, supone mas que una unidad con las prácticas del diseño, un matrimonio de conveniencias) por su maleabilidad reelaborativa, por su seguir siendo — sofisticada ligerezacasi lo mismo para un igual uso.

De diseño(s), o como dice pronto, en las primeras líneas, su comisario Paco Bascuñan, mucho antes de redondear su texto con las citas de Raffaele Simone, Juli Capella e Ignacio Ramoné, de "un recorrido por las nuevas formas de comunicación de lo que, hasta hace poco, hemos entendido como diseño" ${ }^{\prime 18}$, va UN MÓvIL EN LA PATERA, DISEÑANDO EL SIGLO XXI; de la contrastación esclarecedora de esas nuevas formas de comunicación en tanto son ciertas, y para ello toma apoyo en obras de Kyle Cooper-Imaginary Forces,Droog Design, Alberto Martínez, Martín Ruiz de Azua, Hector Serrano, Snowcrash y Tomato, diseñadores unos, provenientes de una formación "analógica", y otros, formados íntegramente en eso que Raffaele Simone a definido como "Tercera Fase"; de reelaboraciones, en unos casos constatables, interactividad, reminiscencias cinéticas, video instalación, intervenciones y objetos de especificidades artísticas. "En principio - dice un amigo, sirviéndose del personaje principal de su novela DE ESPALDA A LA LUNA, publicada hace unos pocos meses en La Habana - una sucesión de vibraciones..., después, tres pitidos o alguna melodía hiriente; entonces advertimos

18 Bascuñan, P., Un móvil en la patera: Diseñando el siglo XXI. Ed. Espai D'Art Contemporani de Castelló, 2001. 
que alguien nos solicitaba atención, nos procuraba telefónicamente". Ikikan kuin inché igbo ${ }^{19}$ No puede haber redefinición ni recorrido, si antes no ha habido, no se ha producido, una aprobación definitiva, una cultural definición, entendida entonces como superación respetuosa, y no por ello menos arriesgada, de lo antecedido. En ocasiones -al margen de lo diseñado con mayúscula, por tanto de la actitud diseño y de sus innumerables acepciones-, parece entenderse como principio definitivo, y definidor, de la estructura como tal construida, el devenir pronto, supuesto, de su estetización, de esa impronta posible, como funcionalidad necesaria. La sola intencionalidad, cual evidente falta de sucesión en la cadena del acontecimiento, se antepone a la constructividad práctica de la cosa, y por tanto a su uso; a esa exactitudpluma, exacta pluma, que ha de hacer nítido, funcional y bello, su cuerpo objetual y estar pretendido, y que como símbolo de la precisión sirvió a los antiguos egipcios para en los platillos de la balanza, entre otras muchas cosas de carácter práctico, pesar las almas.

19 “Un solo palo no hace monte", Refrán en lengua Lucumí usado comúnmente por los más viejos Olorichas o sacerdotes de la santería afroamericana. 


\section{A.15 EL FILO DE MARÍA, ¿UNA EXPOSICIÓN REAL?}

... el peligro de la no-pintura...El día en que cualquier acto de graficación expresiva sea entendido como pintura, ello ha de suponer (en el mejor de los casos) la vuelta sin paliativos a la prehistoria, y por tanto a Lascaux y Altamira, "a la impresión de la maravilla", como diría Blanchot $^{20}$, y al Solutrense y Magdaleniense del arte rupestre; así pues, denotaría, por fin, nuestro arrivo estable al entendimiento primario y esencial - por simple- de la idea de la pintura como conocimiento, como la cosificación de un algo aprehendido, conocido y sabido, desde y a través de la pintura como método; habríamos llegado, empero, al punto desde donde partimos y desde el cual (según parece ser) no debimos habernos separado jamás: del destello primario consumado. En otro de los casos (otra dirección) sería el raso dictamen del fracaso de lo humano ante su condición proyectual, la evidencia, más bien vergonzosa, de la perdida definitiva de la cordura y, algo mas lamentable que incomodo, la perdida de la distancia comunicacional - la condición proyectante se habría deshecho en tanto nuestra búsqueda y atención admirativa habría cuajado sobre la idea de un arte que mejora las cosas, y por ello, ausente de sensación de presencia. Es el problema de la pintura ante el peligro de la no-pinturas lo que me sobrecoge, sobre todo de esto último, de esas graficaciones dadas tal cual si fueran el velo de ilusión originario sin que jamás lo hayan sido, sin que jamás hayan podido rozar el cuerpo del vacío verdadero de la cosa primaria. El arrojo abrupto de graficaciones fantasiosas (digo de lo dado con cierta frecuencia como pintura) no siempre nos habla de una prefiguración discursiva, y menos, de que en lo sucesivo han de devenir en enunciaciones claras, y más que ello, en estables figuras de conocimiento, o en su lugar, de un conjunto definitivo de valores, por tanto, de producciones legítimas de sentidos; así pues, son infinitamente mas las ocasiones en las que por proyecto plástico, que por el acto emancipado de la actitud pintura, se nos da (y vaya pobreza del entendimiento) sólo el reten epidérmico de una vacilación coloreada, el retiniano ser del pudo haber sido posible,

20 Blanchot, M., La risa de los dioses. Taurus Ediciones, S. A., 1976. Madrid. 
como contraposición al proyecto, o como apunté en anteriores líneas, a la condición proyectual. ... la actitud, la condición simple del estamento discursivo o de su proyección trascendente...

Dicho a lo cubano y evitando cualquier resquicio de contención perversamente divina, "El filo de María", titulo de la exposición de Antonio Sosa inaugurada en la Galería Tomas March de Valencia, sería (haciendo alusión al carácter recio y la verborrea ácida del personaje en cuestión) algo así como: María la de ampanga, la de anjá, la arrancapescuezo, o, como desborde final de la metáfora, María cojones, a secas y sin más. En otra acepción lo de "el filo..." tiene que ver con el voyeur, el escudriñar de su mirada pervertida, $y$, a veces, con una cierta voluntad de mostrar, de dejar al descubierto partes del cuerpo que normalmente cubre la ropa; entonces se dice así: una mujer le da un filo a un hombre o viceversa. En este sentido, y claro que los tiros de Antonio Sosa no van en esta dirección, la traducción rápida de "El filo de Maria" al lenguaje coloquial y a la fraseología de un cubano de solar, ha de ser: "aquello que María está mostrando o aquello que se le ve a María". Ahora bien, a la pregunta de ¿y de qué va esto? La respuesta es sencilla, esto va de lo que María nos muestra, de tres niveles de cosas, entrecruzadas y visibles, que transcurren en la exposición de Antonio Sosa: de la memoria plástica (influencias y escuelas escondidas), de lenguajes (niveles de graficación simbólica) y de poetización de lo irónico (articulación de la frase, de la extracción, en giros tendentes a la sugerencia filosa, al re-alumbramiento, unas veces sarcástico, y otras, como ingenuos detenimientos, rápidos en la mayoría de las veces y muy próximos a lo naif en casi toda su extensión).

Eso que llamo memoria plástica en la obra de Antonio Sosa, y que no es mas que el conjunto de huellas, rastros y sentidos latentes, tanto conceptuales como gráficos, manifiestos una y tantas veces en el conjunto de sus obras, no es algo cuyo entendimiento deba tener lugar sobre acotaciones despectivas, no; y es que ese conjunto de cosas, esa memoria plástica —entonces evidente, o tal vez, evidenciada habilidad del uso recurrente de los atajos fértiles, cual arrinconamiento rápido del orden burbujeante-, ese dejarse ver asomado en cuantas puertas 
sean posible, en cuantas fuentes les ofrezcan sus causes limpios y sus bebidas frescas, quizás sea uno de los elementos distintivos en toda la extensión de su obra: un ajiaco que lo contiene todo, siendo siempre un singular ajiaco. En ese orden hay rastros cuya visualización, o si se quiere adivinación, es inmediata: la conexión, tal vez casual (y entiéndase esto como referencias indirectas y sólo como correspondiente a grupos o bloques de obras, pues en muchas otras zonas de la exposición esto varia sustancialmente) con el ordenamiento automático —arrojo frenético- del dibujo de los dadaístas y surrealistas (piénsese en Andrés Masson, Valentine Hugo, Miró, o en obras como "Paisaje "Cadávre Esquís", 1933), sus giros intuitivos, puntualizados en piezas como Ecce homo (2001), hacia los ecos expresionistas de principios del siglo XX, pero también la orientación de su obra (la más próxima a la pintura) hacia la pintura primitiva centroamericana, como de la escuela de Solentiname en Nicaragua, a la pintura popular Haitiana, o la figuración del primitivismo perverso dado en la obra del pintor cubano Manuel Mendive (primitivismo perverso, ante unos juegos dados como ingenuos, la relación a veces forzada entre una gestualidad que intenta desprenderse, simular no ser, o no devenir de una alejada ordenación académica y una graficación descuidad). Los dibujos a los que me he referido (Ecce homo) tienden a ser las ordenaciones más clara respecto en todo el conjunto, puesto que (definitiva suspensión proyectual) nos deja asentados en los márgenes de un civismo real, por tanto, en ello se hace evidente una corporeidad que los aproxima al conocimiento, al hallazgo claro y simple de la cosa estudiada y buscada, desde y con el dibujo, como metodología o instrumento, y como vehículo con el que hacer y para hacer. ... de lenguajes y niveles de graficación simbólica La preocupación de Antonio Sosa por la graficación de sus ensoñaciones, o presencias fantasiosas y poéticas, más que reducirse a la ilustración de ese submundo atrapado entre concepto, parece haberlo conducido a la comprensión de las formas de graficación como sustitutas mismas de la ensoñación, y no tal cual generalmente sucede: el objeto de graficación entendido en términos de lo que ha de ejemplificar.

En los dibujos de Antonio Sosa parece habitar su conocimiento real 
(su ser real-espontáneo y sabedor de un algún que) y no otra cosa, su saber enérgico: el ser humano oculto tras la expresión pura, tras sus graficaciones definitivas, se aprehende más que se perfila, e incluso estaría bien decir que se adivina. Sus dibujos, planos que aguardan dos niveles enunciativos, dos posibles direcciones de cosas, dos historias superpuestas, (todo lo que por otro lado su pintura desdice) siempre resultan más sosegados (por precisos) y modestos que sus enormes piezas pintadas sobre papel, cuyo sostén se detiene rápido, apenas comenzada la exploración de su posibilidad, de su poder ser verdaderamente pintura, dando al traste con el camino nítido (avistado ya en otras zonas de la exposición) de las interrogantes propias del medio entonces usado. ... poetización de lo irónico (articulación de la frase).

Del conjunto de la obra de Antonio Sosa (y claro que de esto me hago plenamente responsable) destacaría —más que el intento de su comprensión como pintor-, como zona única donde con mayúscula se advierte la sensación de presencia, su desfachatez discursiva, su desprejuiciada carrera hacia la articulación de esas frases que sin decir absolutamente nada, lo sugieren todo, o mejor, lo ironiza todo: la contención de más de una imagen iconográficamente popular, de un fetiche (entonces perteneciente a todos), en una espacialidad cuya naturaleza es a priori caótica, o a priori irónica, tal vez potenciadora de las ondulaciones de la frase a recorrer y del definitivo filo que casi nombra la totalidad de la exposición. En esa desfachatez (y hablo entonces de rasgo y de matices picaresco) va la presencia, la sensación de presencia, y por ello, cosa que no ocurre a menudo con la pintura, una cierta incitación al espectador a considerar su actividad como un vehículo de expresión, extensible, en algunos casos (sobre todo en los dibujos) a un posicionamiento metodológico. Sin embargo, a la pregunta de si todo ese esfuerzo y conjunto de cosas comunica alguna idea expresiva, yo diaria que sí y no. Que sí, pues advierto una cierta conciencia, por tanto un claro control y un espontáneo gusto (tal vez, ¿acomodamiento?), por, y sobre, la idea de eso que he llamado desfachatez discursiva. Y no, en tanto en ciertas zonas de la obra se 
deja entrever una puntual oscuridad en cuanto a las razones que han servido de base a sus experimentos y de las ideas que hay tras ello. Tal vez, podría decirse que en todo ello predomina el interés por la sola afirmación de la carga emocional, y por tanto, un elemento más bien instrumental, liberador y linealmente excitante, que por igual no necesita ninguna otra justificación, una vez que se le ha orientado (o reorientado) como carga dinámica para saltar más de una trampa. 


\section{A.16}

OBSERVACIÓN: ESCRITO SOBRE PIEDRA

"Y salido Jesús, íbase del templo; y se llegaron sus discípulos, para mostrarle los edificios del templo. Y respondiendo él, les dijo: ¿Veis todo esto? de cierto os digo, que no será dejada aquí piedra sobre piedra, que no sea destruida." MATEO 24,1-34

Lo reciente entendido como inmediatez parece no contener aquello concerniente a la novedad -al súbito que se le anticipa como reafirmación-a su ser plenamente (¿a lo novedoso?), pero sólo, cual matización de postigas precipitaciones, lo parece. En ESCRITO SOBRE PIEDRA, la exposición de Montserrat Soto, inaugurada en la Galería Luis Adelantado, no hay nada nuevo y a la vez si que lo hay: lo ya ordenado, conocido y sabido, es, por ser una constante, a lo que se contrapone la relación escrito-investigación-sobre-análisis-piedra, o sea, el sentido de los conceptos negativos - para vivir, el hombre necesita asirse, para seguir viviendo promete- que dibujan la otra mitad. En tal sentido - referido únicamente a ese no hay nada primero- permanecen, tal cual una retícula básica, cual acentuaciones imprescindibles, sus diálogos entre elementos artificiales y la naturaleza; las uniones de espacios privados receptores del arte y espacios públicos dedicados a la exhibición y contemplación de las producciones artísticas; las vistas a través de ventanas y puertas; los espacios que sucediéndose continúan en otros que a su vez dejan que se les prolongue en unos otros, que nos invitan a seguir hacia el allá-adentro de problematización y de convergencia entre lo verdadero y lo hecho (acordémonos de "Intervalo", de 1994, que mostraba cuatro salas de exposiciones de Barcelona vacías); también los paisajes vacíos de personajes y no de evidencias presénciales correspondientes 'siempre habita algo en la sequedad y la falta'; como de igual manera también permanecen los paisajes secretos (los de colecciones y de coleccionar, pues igualmente por licitud y placer esos usos han sido más que legitimados), y la reflexiones sobres el dato retenido o archivado y los accesos a la información y al conocimiento. Vista la unidad de cada uno de esos tramos de cosas, ello debería evocarnos una larga cadena de conveniencias: una serie de pactos 
precisos sobre la permanencia de unos en el lugar de lo sublime, y de otros en el lugar de lo práctico. Sin embargo, y aquí descansa mi argumentación, es desde este espacio surcado, ahora territorialidad del todo, donde surge la impronta de una especie de nueva lógica: la observación que Montserrat Soto puntualiza en sus recientes obras - ese 'hacia donde y cómo debe mirarse lo real y hecho', pactado como acontecer artístico- es equiparable a una operación constructiva. Es a base de re-ordenaciones, de la constitución filosa de territorios mixtos, que va articulando el doble rostro y la figuración ambivalente de la cosa por ser, del paisaje otro de las cosas que serán cuando se les observe. Así, pues, es justamente ese 'hacia donde y cómo debe mirarse lo real y hecho', lo que porta la novedad en estas últimas producciones, es - piénsese entonces en piezas como "Sin titulo. Arcos de ciudad I", 2003- lo que resume y aúna lo real-referido (en tanto que es paisaje, memoria o inscripción) y lo hecho palpable (en tanto que es cuerpo de la nueva relación, lo denunciado, lo advertido, lo señalado o lo poetizado). Novedad, esta vez, desplegada en forma de omisiones y de negaciones cerradas: la escena-paisaje primaria no admite otros territorios de continuidad, pero si aquello que los sustituya (las fachadas de edificios, las ruinas) y funcione como barrera, como paredones escenográficos que detienen la marcha de la mirada (en ellos sólo es posible deslizase hacia arriba y abajo, a un lado y al otro, y poco más); la segunda, lo escrito sobre piedra no actúa como alegoría sino como memorias del sí mismo, de lo alejado incuestionable, que sólo puede ser interpretado desde una disciplinada y rigurosa observación - las ruinas parecen estar taponadas por las grandes fachadas de los edificios de alguna ciudad; sin embargo, en otra dirección de cosa, las ruinas visualizan puede que estén visualizando el destino posible de la ciudad actual debido a su crecimiento agresivo, desordenado, atroz. Pero entonces, ¿acaso se nos está hablando de territorios, de territorialidad, de mapas o de escrituras culturales enfrentadas, de ese "no será dejada aquí piedra sobre piedra, que no sea destruida", o de Nablus (la antigua Siquem de la Biblia) y de la inscripción samaritana sobre piedra? Puede ser que sí y puede ser que no, pero lo cierto es que al contrario de lo que en obras anteriores ocurría, a través de estas nuevas piezas no 
se puede vagar así por así, puesto que dos direcciones de cosas lo impiden, dos principios enunciativos que por gemelidad se oponen, interrumpiendo nuestro paso: nacidos de la misma raíz (lo real y lo hecho), el primero intenta llevarnos, a la vez que el segundo intenta traernos. Estos nuevos matices en la obra de Montserrat Soto parecen provenir de un apasionado e irresistible interés por la relación entre los principios generales (lo nuevo y lo viejo, el bien y el mal, la presencia y el vacío), y los hechos tenaces y obstinados (la arquitectura, la escritura, la ciudad, la guerra), que otra vez bien que concilia. 


\section{A.17 DE GESTOS Y MEMORIAS: DE LO QUE 'CARGA' ARRASTRA}

... de cuando la idea deviene sentido. La casa. De Loreta Visic tenemos (nos ha llegado) la memoria de "Laundryhouse", instalación (¿intervención?) realizada para la Bienal de Louvain-la-Neuve en el 2000: la estructura de una casa, según los prototipos de la zona, cuyas paredes fueron íntegramente construidas con prendas de vestir, tal cual las tendederas habituales. Aquella casa — de simbolización- de abrogación, pues se ha pretendido una sustitución esencial, fue una especie de ruptura con su posicionamiento anterior, una explosiva revalorización de su idea de entorno domestico y social; una ruptura, emocional y poéticamente positiva con la noción de catástrofe de lo domestico y de su singularidad dramática. Antes que "Laundryhouse", la obra de Loreta Visic oscilaba entre unos referentes críticos extraídos de los estándares del discurso dominante y la singularización de la idea del arte como posicionamiento crítico — tal vez irónico. Piénsese en sus reflexiones temáticas alusivas a ciertos ambientes familiares devenidos de la desprotección social, o en tanto consecuencia derivada de una cultura harto consumista y mediática y de su contraparte, la pobreza espiritual creciente: la casa resulta ser un infierno, la intimidad se vuelve constantemente una sofocación, las esposas y los niños están abocados a la violencia, la locura y el mal gusto. Piénsese en obras en las cuales Loreta hace un uso, en apariencia inocente, de imágenes referidas a una estabilidad supuesta en ambientes o círculos como el de los amigos y la familia, siendo, en fin, uno y otro el mismo ambiente y círculo: el jardín (Gravegarden, 1999), la niñez (Bear, 1999), el crucifijo, etc. Producciones. Imágenes cuya estabilidad aparente denuncia todo lo contrario, el terror asfixiante y el horror, tal cual el filo fino que proclama ironizando: ¡nada es lo que parece! ... la casa publica/ acontecimiento real. Tras aquella casa, entonces variable y cambiante, radiante de color y de orden (la estructura permanece, sin embargo, los cambios de luz, temperatura, y la dirección del viento, permiten una visualización distinta, y si se quiere nueva, de la idea de la casa), la obra de Loreta adquiere un aspecto - mas que ambivalente, como una vez se dijo haciendo alusión a "Crucifix" (2001), en tanto resultaba problemática su clasificación 
genérica - vivaz, y si se quiere socializado, tal cual si la comprensión de lo común incluyera en ello lo diverso como lo que faltaba en sus cadenas enunciativas, y entonces, lo lúdico y lo participativo como fundamental. Una liberación implica liberaciones sucesivas; y en ello, como condición necesaria para esa sucesividad de aconteceres, ha tenido lugar la aparición de una forma interior, de una figura anticipada de la posible (ya) relación (memoria/ diversidad/ crítica/ presencia/comunidad) que se proyectará entonces como social o por lo menos, en esa primera línea de la enunciación, será tenido en cuanta como suelo espiritual. Con "Laundryhouse" como intervención publica, como acontecimiento real - y el arte publico en mas de una ocasión ha señalado esa senda que no solo rubrica lo artístico sino también su función activamente social y de puesta en común-, la posterior obra de Loreta empieza a estructurarse como ambientes (teatros de operaciones), como ocurre en "Carga" (2003), un poderoso conjunto, cuya disposición, casi escenográfica, incita a la pronunciación y por tanto a usar su espacio y entorno correspondiente como centro de la probable actuación, o en su caso como suelo social de implicaciones y de actividad.

... de gestos y memorias: de lo que Carga arrastra. Aun en ello hay memoria y, por tanto, conservada y latente más de una presencia. En el entretejido, en los tensores que constituyen las prendas de vestir, esta el síntoma, se hace el primer síntoma - primer elemento en la cadena de ideación del drama domestico. Las ropas acotan y a su vez conectan unos momentos y otros en la obra de Loreta. Sin embargo, cosa sutil, esas mismas ropas producen tensión: tras la vivacidad de las coloraciones un hilo de dura ironía se extiende y, como en los viejos tiempos, critica. Nada de quietud, lo envolvente no es reposo ancestral. Entonces se me ocurre pensar que en "Carga", esta obra última de Loreta, también sobrevuela melancólico el fantasma de "Laundryhouse", pero esta vez ligero y, quizás, algo perverso. En ella (Carga), de ser cierto ese sobrevolar al que me he referido, se le confiere a la imagen un distinto alcance: es gestualidad, por cuanto se manifiesta como contraimagen de la quietud, la acción publica que la antecede y refiere directamente, en este caso "Laundryhouse", sobreviene una y otra vez; y 
es memoria, a la vez que no omite, sino mas bien sublima su procedencia dramática. 


\section{A.18 BATHROOM ACTION: ACONTECIMIENTOS DE LOS USOS}

(...) Claro que se puede decir que esos objetos de aspecto ligero y simpático, construidos a base de vinilo transparente por Suzanne Déry y Anthony Burnhacm, son como juguetes (grandes juguetes) pensados para adultos, y claro que también puede decirse que sus proyectos, en principio escultóricos y luego multimedia y performáticos, engloban las tácticas, áreas y las referencias, donde esos adultos deberán jugar y someterse de nuevo a la acción de lo lúdico, lo tecnológico y la sorpresa. Sin embargo, más que de sus objetos hablaremos de una condición-otra que partiendo de ellos se proyecta en la totalidad de sus obras; hablaremos del acontecimiento de los usos, de la fetichizaciónabrogación con que The Flators se manifiesta, y que es por tanto visible $-\mathrm{o}$ en todo caso cómodo, por intenso, para una posible categorización-, en su obra "Bathroom action", un proyecto pensado para ser desarrollado en un primer momento en la ciudad de Valencia, con el apoyo del Departament D’Escultura de la Universidad Politécnica de Valencia, y luego en la ciudad de Madrid con el patrocinio del Instituto de la Juventud (Injuve).

... de colaboraciones y reconocimientos: juntar la mirada posible

El reconocimiento y la aproximación entre personas o grupos sociales se produce en un primer momento de manera instintiva, luego de forma metódica: inicialmente los sentidos (la animalidad y los censores de intuitividad) ordenan, después, la mirada (en sí condición proyectual) recorre, hace el recorrido trazándolo. Algo así debe haber ocurrido en 1993 entre Suzanne Déry y Anthony Burnhacm cuando intercolaboraron en la universidad de Concordia, en Montreal — colaborar quiere decir transparentar los métodos, hacerlos tolerantes a la porción distinta y al posicionamiento del otro, superponerlos (uno sobre el otro o el otro sobre el uno), y que como unidad de convenientias se desplacen o actúen. Sin embargo, para que esa unidad de convenientia funcione, estabilice la emanación consecutiva de enunciados, primero han de ser ambas partes (han de haber sido) rigurosamente distintas, y por ello, complementarias 
para la posible unidad, en este caso discursiva, poética, o como se le quiera llamar.

... el lugar ideal de colaboración: un paso en la aproximación y posterior entrelazado discursivo. Lógica escultórica-objeto de la novedad. De cómo resolver la metáfora del deseo primario: ver la obra tal como se la imagina, como ha sido vista en la idealidad, en el lugar ideal de la colaboración, vehiculiza, y casi exige, la puesta en común del proyecto de intervención pública Inflable \#1 (1995), que perfila en sucesividad, aspiración estética y pragmática constructiva, la andadura en progresiva sofisticación de lo que en lo adelante será The Flators. El objeto que se produce, aunque desposeído de la pesadumbre de los materiales habituales en la actividad escultórica, no deja de serlo: la voluntad ordenativa aun se antepone a la disposición proyectual, a la mirada que recorre y traza. Sin embargo, ya en la experiencia primera de Inflable \# $\#_{1}$ (y entonces en las sucesivas) se ha habilitado, cual buen cultivo, un valor de distinción de la cosa: el ordenamiento del acontecer de los usos. ... otros usos, otras modas, asirse a la idea: el proyecto no es el objeto. Cartografía de la usanza. Advierto que el uso, ese distinguir práctico de la cosa y con ella, tanto del objeto como del entorno, hace de estructura que deviene a su vez en cerrazón necesaria (la idea no ha soportado seguir siéndolo y ha devenido en objeto) y en acontecer perplejo, casi en simulacro. Sobrevuela por tanto, y de hecho se impone, entonces a escala del individuo artista y de su circulo de amigos más próximos, y sólo a nivel de la pragmática constructiva de la obra y la selección de los objetos que la constituyen - cosa esta no exclusiva del entorno museístico-, un sentido de fetichización del objeto: si no es proyección ideada (ejemplo su obra "Automobile", 1999), es entonces problema - harta condición de problematizaciones. El proyecto no es el objeto: sus límites no se detienen en la figura de la cosa ni en la estructura-complemento que reclama. Su cerrazón tiene que ver cada vez mas con el acontecer de los usos, con el desplazamiento de lo ideado - el rol deviene en el objeto de la acción: el carácter fantasmal, nada aterrador sino más bien simpático y de ligereza, se nos ocurre una ironía fina, filo hilado de los usos y de la memoria tenue, que insiste-, que con la conservación del objeto de la novedad.... practicabilidad de lo 
supuesto: lo que en principio alterna al final sustituye.

La reivindicación de nuevos usos (por tanto concretos y específicos) del new objet y de los entonces objetos legítimos, orientados hacia estándares del arte se identifica por un lado con una reivindicación del sujeto personal y la constitutividad de su acción, y por el otro, con la búsqueda de libertad y de placer. La ética (y aquí se habla de la actitud ante el devenir posible de lo estructurado) de los new objet de The Flators es mas un contencioso que un contenido dicho y, por igual, resultado de la estructuración de cosas: el cuarto de baño, por tanto y obviando sus destinos genéricos, no tiene por qué ser siempre un espacio de acogida solo para los fluidos, y a veces perversiones, del cuerpo, cuando a su vez lo puede ser de acogida y acontecer poético. El objeto y el entorno, la referencia y el uso, el contenido y continente, la poética y la poesía, la función (papel social del arte) y sentido, articulan en su inicial conjunción, y como principal naturaleza del acontecimiento performático, los proyectos expositivos de The Flators. 


\section{A.19 FRONT I, II Y III}

A veces declinamos contrastar las cosas que la mirada valorativa de otros sectores culturales y sociales nos exige que tengamos en cuenta, e incluso, que llevemos a los foros de discusión. Entre éstas quizá sea el estado crítico del panorama plástico valenciano una de las más importantes. En este sentido, los comisarios, Álvaro de los Ángeles y Ricardo Forriols, han llevado a cabo el proyecto Front que, encajado en la celebración del vigésimo aniversario de la galería Edgar Neville, no sólo les sirve como estrategia argumental para la problematización del ambiente que nos rodea, sino también como ejercicio de señalización y plataforma de lanzamiento (ore-lanzamiento) de un grupo de artistas cuyas propuestas, al margen de las analogías estéticas, discursivas o políticas, deben -según los organizadores- empezar a ser centro de atención de los nuevos debates sobre el estado de las prácticas artísticas en Valencia.

En un territorio denominado por los comisarios como "el contexto" (la combinación de los dos espacios expositivos), ha tenido lugar Front. Pensada como una especie de recuperación del talante de las iniciativas que hace veinte años el mismo espacio acogió, la primera de las tres partes en las que ha estado estructurada la exposición (Galería Edgar Neville, del 17/X al 20/XI) reunió, por un lado, obras de Sergio Barrera, Oliver Johnson, Nico Munera, Juan Olivares o María Cremades, cuya reflexión versaba sobre los problemas concernientes a la naturaleza de la pintura y la idea de lo pintando y que, en cierto modo, entroncaban con las problemáticas planteadas entonces (dotar a de frescor a la pintura) en exposiciones como Recién Pintado y por otro, obras de Carlos Domingo, Juan Canales, y Deva Sand (intervención y objetos), algo más abiertas y tendentes a conciliar pintura, ambiente y escultura, estableciendo así un paralelismo con la dinámica de la práctica escultórica de los años ochenta en esta comunidad.

La segunda entrega (Aula de Cultura CAM, del 25/XI al 30/XII) ha querido desarrollar un diálogo entre lenguajes y disciplinas diversas con el fin de trazar un lugar común entre las imágenes, el tiempo y el movimiento. Para ello, se han escogido obras de María Ortega 
(intervención pensada para la sala de documentación), Francisco Sanmartín (instalación audiovisual, producto de sus investigaciones en torno a la posibilidad expresiva del ruido y el error en la imagen videográfica), Chema López (pinturas pintadas en blanco y negro, cuya calidad y temperatura nos recuerda a las calidades cinematográficas), Joël Mestre (objeto-escultura, combinación de osamentas y materiales de los procesos escultóricos) y Bleda y Rosa (fotografías referidas a la memoria de entornos y culturas ancestrales). Todo un conjunto que, por su naturaleza diversa, ha servido para configurar un espacio de diálogo, co algún que otro altibajo significativo.

Esto no ha sucedido en la tercera parte de esta trilogía expositiva (de nuevo Galería Edgar Neville, del 20/XI al 30/XII), en la que lo definitorio, el relato estable $\mathrm{y}$, si se quiere, lo conveniente, es lo que caracteriza y unifica todo el conjunto de obras; como la instalación de Pilar Beltrán (y sus cuestionamientos sobre los sistemas de vigilancia y el control públicos), la de Pedro Ortuño (presentación de la experiencia de varios cineastas comprometidos con causas sociales, personales y políticas), las de Mira Bernabeu (una puesta en duda de la veracidad de la información de determinados hechos), las de JMGI (fotografías extraídas de fotogramas de sus vídeos), y las de Moisés Mañas (realizadas para internet, a partir de la reelaboración y aprovechamiento de los vínculos rotos y datos basura encontrados en la red). Discursos todo ellos diferentes pero que, gracias al modo en que ha sido activados, conviven. 


\section{A.20 ARTS AL PALAU: VARIAS SOSPECHAS, UNA AFIRMACIÓN}

Una, dos, tres... ¿Tres colaboraciones? ¿Tres estados de un mismo relato, de un inicial relato que en un último tramo de cosa ha devenido en tres situaciones otras, pero de conjunción? Una... y de una actuación posible. Tratándose de intervenciones, actuaciones o acumulaciones, de colocación o bien de poéticas y entendidas imposiciones, el entorno de los Borja - el Palau Ducal, su familia e historia - impone un más que justificado respecto: primero, cosa que luego se invierte hasta definitivamente embaucarnos, da muestra de su arquitectura (un edificio fechado en el siglo $\mathrm{XV}$, que luego fue restaurado y transformado en santuario por los jesuitas); después, tras habernos casi adormilado, nos pone en el camino de su intensísima y a veces intrigante y polémica historia, que incumbe el nacimiento de San Francisco de Borja, inspirador de la contrarreforma y general de la orden de los Jesuitas, y a una influyente y poderosísima familia como la de los Borja. Crece el tramo: la cantidad se hechiza. En este punto, aparece como inevitable la problemática de la condición funcional del espacio [el de los Borja] en tanto habitáculo dinámico y de recepción: ¿El entorno soportará la idea, las ideas asumirán los ámbitos? El punto aún persiste, se amplifica... Sin embargo, todavía aquí, y también como inevitable, toma cuerpo una fundamental cuestión: arquitectura e historia [la que concierne al Palau] tolerarán tres direcciones discursivas, de por sí temporalmente alejadas, y por ello, alejadas también en cuanto a sus temperaturas formales. Aquí, a un tiro de ballesta, entonces como obviedad, late el dar lugar, el hacerse camino primigenio que la práctica artística consagra - se abre así la posibilidad de una colaboración. Tenemos así, que esa condicionante inicial, la del respeto a la arquitectura y la historia, ha sido sumida (entendida) por Maribel Domènech, Evarist Navarro y Emilio Martínez, como hacedores - hacen lugar en - del más ambicioso proyecto expositivo de arte contemporáneo que, en sucesivas ediciones anuales (gestionadas por Josep Ramon Millet Pons), acogerá el Palau Ducal deis Borja. Primera condición problemática - el acercamiento deviene complejidad. Dos... de la condición dada, hecha lugar. ¿Acaso el condicionante arquitectónico e histórico no 
merece ser entendido como un problema? ¿Invita acaso a una reflexión sobre la relación de quien actúa y el paisaje técnico que lo envuelve? Pensemos por un momento que el Palau Ducal deis Borja no es sólo una estructura arquitectónica y su historia, sino el resultado, tanto en su tiempo como en éste, de innovaciones de carácter técnico, conectados o en correspondencia con una horizontalidad (poder o pretensión de poder) orientada a devenir siempre en modélica. Así pues, para el artista (los artistas) aparece - siempre debería aparecer - una primera cuestión relaciona con la orientación del proyecto, con la propuesta de hacerse lugar, con el definitivo momento instituidor, respecto a los condicionantes iniciales. Vaga entonces la idea-pregunta de qué hacer o como actuar definitivamente en ese contexto, en sus salones, en la Galería Dorada, por ejemplo, de estilo barroco, o en el Salón de Coronas, o en el Salón de Águilas. Todo, por tanto, apunta a otras dimensiones significativas, a reciprocidades y trasvases intensos: en ello no irá nada de carácter simbólico ni de alegorías, pues el espacio del Palau Ducal ya, en si mismo, y de igual manera, viene representado por su propia arquitectura e historia - el espacio ha de volverse extensio.

Intervenir. Otra sospecha. Evarist Navarro interviene, se planta trasgresor y competitivo ante el resquicio gótico-renacentista visible en dos de las puertas del Palau Ducal, sin que para nada, la integración que suponen sus "Arquitecturas paralelas", desentonen con la armonía y la memoria espacial, e histórica, de su fachada y entrada al patio del Palacio. Sus "edificios paralelos o añadidos", cual condiciones figurales, cual entidades antepuestas (anteriores), actúan como fachadasmáscaras pero sin funciones, sin la función práctica que la estructura arquitectónica inicial - de donde han devenido objetos paralelos le ha debido heredar. Así, esas "arquitecturas paralelas", sin funciones, sin pesos estructurales problemáticos, sin planos, son una suerte de grado cero de la arquitectura, tal cual si de ellas sólo permaneciera el rol; es precisamente por ello, por ser grado cero, por ser rol, que su integración se da de manera absoluta: la estructura arquitectónica inicial parece absorber cada una de las estructuras paralelas, a todo un conjunto de obras cuya cualidad primera es la de la cohabitar, la de 
transitar paralelamente a un modelo conveniente. Es la relación función no-función entre la obra y su modelo arquitectural inicial, lo que define estas nuevas piezas de Evarist Navarro, que por igual, han evitado (superado) quedar disfrazadas por la teatralidad modélica del cuerpo histórico con el que conviven. De la persistencia sobre la identidad arquitectural del modelo inicial es que nace el doble infuncional, la extensión arquitectura paralela. Sin embargo, ese doble infuncional es posible, ante la identidad arquitectural inicial, sólo en su prolongación, en la extensión arquitectura paralela o añadida. Última sospecha. Emilio Martínez con su pieza "La conversación" colabora; da lugar a una obra cuyo origen tiene que ver con el mismo entorno en el que actúa: nace sólo de la relación necesaria entre el ámbito del Palau Ducal y la disposición proyectual del autor. En tal sentido "La conversación" es obra y a la vez necesidad de obrar, es interrupción de órdenes y a la vez reconexión de espacios, de espacios de universalidad, de los que incumben a la arquitectura del Palau Ducal, como a los de un espacio poético cualquiera: unas recitaciones dialogadas de fábulas escritas por Gibran Khalil Gibran dibujan la figura definitiva de la pieza - una figura de colaboración que definitivamente ha de producir espacio. Un espacio, sin duda, que incumbe a una figura puente, y que arbitra las temperaturas tanto histórica como espacial de los salones por los que transcurre la normalidad: una larga mesa, en la que permanecen anclados dos monitores de PC, y un conjunto de telas cuya decorado es diverso, es suficiente para establecer la colaboración, para establecerse colaboración y a la vez intermediación entre salones. El comportamiento, más bien dinámico de "La conversación", tiene que ver con algo que a su vez ocurre con el entorno que le enclava o acoge: el entorno entidad antigua -, como le ocurre al objeto antiguo ante el encuentro con una estructura objetual reciente, cede parcialmente su distinción; y así, en la medida en que los elementos recientes ganan en intensidad, él [entorno], es vivido de otra manera, casi como un signo excéntrico que ha solapado su ser definitivo, aunque ya de sobras consumado. Esta relación de comportamientos, más que otra cosa, lo que hace es acentuar, distinguir (cosa que podría entenderse como un hábil recurso) en "La Conversación" y el conjunto de la obra de Emilio Martínez una 
dirección enunciativa sumamente importante que es la capacidad de no exigencia de autenticidad, cosa que libera a la pieza de la obsesión de la certidumbre: del origen, el autor y de su signo. Una afirmación. En Arts al Palau nuestros artistas dicen, del ámbito Borja, todo lo que es: no un absoluto silencio, no un desbordante ruido histórico, sino un universal en estrechísima relación con un paisaje que a todos nos concierne. Tres.... primera sospecha. El Palacio de los duques de Gandía es una especie de huella, de señal testimonio de la transición del gótico al renacimiento, que tal vez simbólicamente, o, quizás, en un sentido rigurosamente práctico, asigna a dos estados de cosa un lugar específico: así pues, contiene en su voluminosa estructura, como una doble condición, una parte de un periodo y otra de otro, de una cosa, y permítanme la vulgarización, y de otra, lo que nos permite deducir que en ello existe, en latencia, la posibilidad constructiva de estructuras absolutamente ambiguas, de estructuras de convenientias. Sospecho, para bien, que a Maribel Domènech, Evarist Navarro y Emilio Martínez, de inicio les ha sobrevolado el Technítes con su ideal figura (la del confiado), y que en efecto les ha dado un buen resultado. Cual si los tres se hubieran hecho la misma lectura aproximativa, también parece, de principio, haber percibido lo mismo, la sensación (igualmente es un recurso estratégico) o algo así, de como si los fantasmas necesarios que habitan los rincones de Palacio de los duques de Gandía se negasen (siempre se hubieran negado) a ser el resultado de tan intensísima historia de convenientias y de intrigantes asociaciones, y en su lugar prefiriesen una presencia al margen, un estar paralelo $y$, en definitiva, calmado; por tanto, parecen haber acordado, para que molestarlos. Poner en su sitio algo... Maribel Domènech ha colocado. A sabiendas ha puesto (concedido) en el salón Galería Dorada una de las obras (COMME UNE CHAMBRE PLEINE DE LUMIERE 1998. Instalación variable. Cable eléctrico blanco y 48 tubos de $4 \mathrm{w}$ de luz negro), más importantes e intensa producidas por ella en los diez últimos años, que formó parte de su exposición ¿QUÉ HAGO AQUí? 1998, diseñada para el espacio Less Brasseurs, en la ciudad de Lieja. Colocada, así colocada, la COMME UNE CHAMBRE PLEINE DE LUMIERE, espacia, libera, a su vez liberándose, el contenedor que la acoge - la Galería Dorada y su aledaño - , y lo sume 
necesariamente en una integración. En la obra de Maribel, comienzan a aflorar una serie de enunciaciones hasta ahora no vistas; incluso, en el caso de que lo hayan sido, podría hablarse de visionamientos cariñosos pero no correctos, y de descriptivos pero no esenciales. Por ejemplo, lo que hasta ahora hemos entendido como referencias a lo femenino (mejor, como una cierta aproximación al feminismo y su comportarse) en sus objetos-vestidos, al margen de que como figuras nos recuerden algo parecido, pierde objetividad - sin que por ello la dimensión cualitativa de las piezas desaparezca - ante el argumento la aproximación figural, que responden a adaptaciones (cuando las referencias insinúa cosas) sólo de carácter temático o, y como recurso lícito, a la analogía como un acto de sustitución; por ello deberíamos pensar que sus objetos-vestidos jamás nos dirigen orientativamente hacia la prenda útil, la de vestir (la de ocultar), puesto que son más bien estructuras comunicantes - el enunciado transita como líquido o fluido-señal a través de un tubo-figuración, de un hilo de figuralidad. Es por ello que COMME UNE CHAMBRE PLEINE DE LUMIERE, esa especial estructuravestido, niega en este nuevo emplazamiento, cualquier exigencia de lo funcional, y en todo caso, de suponérsela, orienta ese calculo a responder a comportamientos de otra índole: testimoniales tal vez, antes que evasivos. Tres.... primera sospecha. El Palacio de los duques de Gandía es una especie de huella, de señal testimonio de la transición del gótico al renacimiento, que tal vez simbólicamente, o, quizás, en un sentido rigurosamente práctico, asigna a dos estados de cosa un lugar específico: así pues, contiene en su voluminosa estructura, como una doble condición, una parte de un periodo y otra de otro, de una cosa, y permítanme la vulgarización, y de otra, lo que nos permite deducir que en ello existe, en latencia, la posibilidad constructiva de estructuras absolutamente ambiguas, de estructuras de convenientias. Sospecho, para bien, que a Maribel Domènech, Evarist Navarro y Emilio Martínez, de inicio les ha sobrevolado el Technítes con su ideal figura (la del confiado), y que en efecto les ha dado un buen resultado. Cual si los tres se hubieran hecho la misma lectura aproximativa, también parece, de principio, haber percibido lo mismo, la sensación (igualmente es un recurso estratégico) o algo así, de como si los fantasmas necesarios que 
habitan los rincones de Palacio de los duques de Gandía se negasen (siempre se hubieran negado) a ser el resultado de tan intensísima historia de convenientias y de intrigantes asociaciones, y en su lugar prefiriesen una presencia al margen, un estar paralelo y, en definitiva, calmado; por tanto, parecen haber acordado, para que molestarlos. Poner en su sitio algo... Maribel Domènech ha colocado. A sabiendas ha puesto (concedido) en el salón Galería Dorada una de las obras (COMME UNE CHAMBRE PLEINE DE LUMIERE 1998. Instalación variable. Cable eléctrico blanco y 48 tubos de $4 \mathrm{w}$ de luz negro), más importantes e intensa producidas por ella en los diez últimos años, que formó parte de su exposición ¿QUÉ HAGO AQUí? 1998, diseñada para el espacio Less Brasseurs, en la ciudad de Lieja. Colocada, así colocada, la comme unE CHAMBRE PLEINE DE LUMIERE, espacia, libera, a su vez liberándose, el contenedor que la acoge - la Galería Dorada y su aledaño - , y lo sume necesariamente en una integración. En la obra de Maribel, comienzan a aflorar una serie de enunciaciones hasta ahora no vistas; incluso, en el caso de que lo hayan sido, podría hablarse de visionamientos cariñosos pero no correctos, y de descriptivos pero no esenciales. Por ejemplo, lo que hasta ahora hemos entendido como referencias a lo femenino (mejor, como una cierta aproximación al feminismo y su comportarse) en sus objetos-vestidos, al margen de que como figuras nos recuerden algo parecido, pierde objetividad - sin que por ello la dimensión cualitativa de las piezas desaparezca - ante el argumento la aproximación figural, que responden a adaptaciones (cuando las referencias insinúa cosas) sólo de carácter temático o, y como recurso lícito, a la analogía como un acto de sustitución; por ello deberíamos pensar que sus objetos-vestidos jamás nos dirigen orientativamente hacia la prenda útil, la de vestir (la de ocultar), puesto que son más bien estructuras comunicantes - el enunciado transita como líquido o fluido-señal a través de un tubo-figuración, de un hilo de figuralidad. Es por ello que COMME UNE CHAMBRE PLEINE DE LUMIERE, esa especial estructuravestido, niega en este nuevo emplazamiento, cualquier exigencia de lo funcional, y en todo caso, de suponérsela, orienta ese calculo a responder a comportamientos de otra índole: testimoniales tal vez, antes que evasivos. 11117 Intervenir. Otra sospecha. Evarist Navarro interviene, 
se planta trasgresor y competitivo ante el resquicio gótico-renacentista visible en dos de las puertas del Palau Ducal, sin que para nada, la integración que suponen sus "Arquitecturas paralelas", desentonen con la armonía y la memoria espacial, e histórica, de su fachada y entrada al patio del Palacio. Sus "edificios paralelos o añadidos", cual condiciones figurales, cual entidades antepuestas (anteriores), actúan como fachadasmáscaras pero sin funciones, sin la función práctica que la estructura arquitectónica inicial — de donde han devenido objetos paralelos le ha debido heredar. Así, esas "arquitecturas paralelas", sin funciones, sin pesos estructurales problemáticos, sin planos, son una suerte de grado cero de la arquitectura, tal cual si de ellas sólo permaneciera el rol; es precisamente por ello, por ser grado cero, por ser rol, que su integración se da de manera absoluta: la estructura arquitectónica inicial parece absorber cada una de las estructuras paralelas, a todo un conjunto de obras cuya cualidad primera es la de la cohabitar, la de transitar paralelamente a un modelo conveniente. Es la relación función no-función entre la obra y su modelo arquitectural inicial, lo que define estas nuevas piezas de Evarist Navarro, que por igual, han evitado (superado) quedar disfrazadas por la teatralidad modélica del cuerpo histórico con el que conviven. De la persistencia sobre la identidad arquitectural del modelo inicial es que nace el doble infuncional, la extensión arquitectura paralela. Sin embargo, ese doble infuncional es posible, ante la identidad arquitectural inicial, sólo en su prolongación, en la extensión arquitectura paralela o añadida. Última sospecha. Emilio Martínez con su pieza "La conversación" colabora; da lugar a una obra cuyo origen tiene que ver con el mismo entorno en el que actúa: nace sólo de la relación necesaria entre el ámbito del Palau Ducal y la disposición proyectual del autor. En tal sentido "La conversación" es obra y a la vez necesidad de obrar, es interrupción de órdenes y a la vez reconexión de espacios, de espacios de universalidad, de los que incumben a la arquitectura del Palau Ducal, como a los de un espacio poético cualquiera: unas recitaciones dialogadas de fábulas escritas por Gibran Khalil Gibran dibujan la figura definitiva de la pieza - una figura de colaboración que definitivamente ha de producir espacio. Un espacio, sin duda, que incumbe a una figura puente, y que arbitra 
las temperaturas tanto histórica como espacial de los salones por los que transcurre la normalidad: una larga mesa, en la que permanecen anclados dos monitores de PC, y un conjunto de telas cuya decorado es diverso, es suficiente para establecer la colaboración, para establecerse colaboración y a la vez intermediación entre salones. El comportamiento, más bien dinámico de "La conversación", tiene que ver con algo que a su vez ocurre con el entorno que le enclava o acoge: el entorno entidad antigua - como le ocurre al objeto antiguo ante el encuentro con una estructura objetual reciente, cede parcialmente su distinción; y así, en la medida en que los elementos recientes ganan en intensidad, él [entorno], es vivido de otra manera, casi como un signo excéntrico que ha solapado su ser definitivo, aunque ya de sobras consumado. Esta relación de comportamientos, más que otra cosa, lo que hace es acentuar, distinguir (cosa que podría entenderse como un hábil recurso) en "La Conversación" y el conjunto de la obra de Emilio Martínez una dirección enunciativa sumamente importante que es la capacidad de no exigencia de autenticidad, cosa que libera a la pieza de la obsesión de la certidumbre: del origen, el autor y de su signo. Una afirmación. En Arts al Palau nuestros artistas dicen, del ámbito Borja, todo lo que es: no un absoluto silencio, no un desbordante ruido histórico, sino un universal en estrechísima relación con un paisaje que a todos nos concierne. 


\section{A.21 VARIA LA LUZ Y EL COLOR (AMARILLO/AZUL)}

El proceso (el transcurrir, el continuo). Nada acota absolutamente nada. Los trasvases ante ser constantes - una cosa trasvasa, si no todo su contenido, al menos una parte significativa de él a(/) otros contenidos también de cosas. Dos planos de color son por igual dos zonas [formas] de luz -o bien formas-imagen. Dos frecuencias, por un lado, inducidas a la cohabitación y, por otro, una absoluta coincidencia, un accidente en medio de una relación cohabitativa mayor. De la relación dos planos de color (AMARILLO-AZul) sólo interesa su naturaleza, o mejor la combinación complejidad-naturaleza-contextualización; el modo de división objetual (dimensiones, fines, medios) es limitado porque no supone cooperación sino simultaneidad; teóricamente ha de suponer una fisicalidad (un borde) que interrumpa el continuo y actúe como significación de las partes o del límite. Dicho de otra manera, cuando se piensa en un plano Amarillo, o en uno Azul, el ataque imaginativo [supone] construye necesariamente una imagen de iguales paralelos o simultáneos a los que se les opone, uno que es lo mismo, a la relación imagen-color (AMARILLO-AZU) inicial que se comporta como imagen persistente. Cada dispositivo de transmisión deviene (necesariamente hace devenir) la naturaleza de la imagen inicial en otro cuerpo de cosa, en una en un "ya no ves lo mismo", reconocible cada vez que sea encontrado en la experiencia.

La imagen apunta a lo desensillan. La cuestión es encaminar la estrategia práctica hacia la idea de una cierta relación con el modo en que obra la naturaleza, hacia la idea de las relaciones o bucles de cohabitabilidad de las cosas, o (en el obrar) hacia una experiencia de relacionar cuya objetividad práctica descansa en el principio de las configuraciones abiertas de los sistemas, y por consiguiente en la imposibilidad de total descripción. Esto es, dejar de someter cada obra (¿práctica?) al estado reducido (acabado, cerrado) de objeto-cosa -a toda obra generalmente se me hace tira unos límites: principios, finales, dimensiones o relaciones lógicas entre las partes. En tal sentido, y como principio de diferenciación, la ruptura con el esquema dimensión-fines- 
medios (proyecto-estructura-configuración), estaría encaminado hacia una conciencia del suceso (acción-contexto), del transcurrir complejo del obrar y la obra, hacia una conciencia de sustitución (en el uso) de la idea del objeto de la práctica plástica (dimensión-fines-medios) por la de objeto-proceso de conocimiento o configuración práctica abierta.

"los objetos se mueven, la calidad y la luz del día cambian, nuestra posición respecto a lo que contemplamos nunca es exactamente la misma ${ }^{21 \prime \prime}$

\section{Rudolf Arnheim.}

Imagen-dirección-esencia/ imagen-dirección-registro de lo real. El ángulo desde el que miramos los dos enormes planos de color (AMARILlO-AZU) en este gran patio en el que nos encontramos no es exactamente igual al ángulo desde el que los advertimos al adentrarnos en él. Tampoco la calidad de la luz que hemos percibido al entrar en el patio de este palacio es la misma que ahora percibimos, i será en un instante. En cuanto a los planos AMARILlo-AZU, en cada uno de ellos el color inicial a nuestro encuentro no es el mismo AMARILLO-AZU que ahora observamos y no lo será pasado un tiempo. Así mismo la naturaleza de la imagen-color AMARILLO-AZU, varía en correspondencia con el dispositivo que la acoge; el trasvase de la condición imagen-color inicial [física] deduce un desvanecimiento de su calidad-imagen primaria, pero, a la vez, instaura una nueva calidadmedio: la acogida por un dispositivo electrónico aporta a la imagencolor AMARILLO-AZU una naturaleza numérica (digital) nueva, por lo que asegura su constancia (\#FFFFOo, \#4BOo82). El trasvase sucesivo de la relación AMARILLO-AzU, de su naturaleza división hacia una (otra) condición imagen-pantalla o imagen-luz es, a la vez, para (y desde) esas cualidades de sucesividad, una configuración progresiva que clasifica y una configuración especifica que diferencia.

Experiencia-relación-conocimiento. La consideración de la naturaleza

$21 \overline{\text { Rudolf Arnheim, buscar referencia... }}$ 
[su modo de obrar], la cualidad y calidad de imagen (variaciones), pide los trasvases sucesivos de los medios (en tanto que dispositivo de registro y de transmisión de las imágenes-dato), más que una combinación de mensajes que en apariencia evocan contenidos hipotéticos y solamente ideales, es un posicionamiento en el uso mismo de cada comprensión: ver deberías seguir implicando pensar. Una experiencia de relacionar, como en este caso AMARILLO-AZU, designa -y claro está que esta cognición tiene su base en los aspectos más generales de ello como relación- un campo de acción [viable] y su adecuación crítica (tal vez, aproximación crítica) a unos tipos de lenguajes-medios a los que ha de atribuírsele un carácter otro en la experiencia, pero sobre todo un cuerpo de imágenes tan específicas como la especificidad que demande el propósito. La cosa consiste en que comparezcan zonas o partes -todas relacionadas- que permanecen escondidas, consiste entonces en transmutar (en la nueva relación) el valor de lo ya visto en cada caso, de lo perdido a fin de cuenta por ser conocido (como lo verdadero y lo distinguido) en una y otra parte. 


\section{A.22 EXPERIENCIA DE RELACIONAR: CIUDADANO-LUGAR}

Los elementos que configuran el proyecto "Experiencia de relacionar: ciudadano_lugar" están diseminados alrededor del edificio del ayuntamiento; si accedemos por la calle Major encontramos tres mástiles que podrían ser los que portan las banderas institucionales (bandera nacional, regional y de la comunidad europea) pero en este caso, la imagen impresa representa a distintos ciudadanos de Xavia, desde los balcones del ayuntamiento se descuelgan tres pancartas que contienen la imagen de estos ciudadanos con unas palabras incomprensibles para aquellas personas que desconozcan la lengua yoruba y unos lemas que aluden a la memoria; estos elementos están acompañados por tres carteles de texto situados en las escaleras que bordean el ayuntamiento y que reflexionan sobre el espacio de la ciudad y la construcción cultural. Durante la inauguración entregamos a los espectadores cientos de pequeños banderines con las imágenes contenidas en las tres grandes banderas; la importancia estratégica de esta acción consistió en la posibilidad real que nos ofreció de acercamiento a los ciudadanos de cuyas historias y construcciones culturales estábamos tratando y de la participación e intercambio de ellos no como representaciones de si mismos sino como condicionadores de la totalidad de la intervención.

La primera imagen que teníamos de Xavia nos venía dada por los carteles y las guías turísticas, casi se podría decir que la imagen de una ciudad hoy se identifica con ese tipo de imagen institucional; la primera idea que surgió tenía que ver con la temporalidad, el tiempo histórico de la ciudad y la memoria de sus ciudadanos, se trataba de localizar el lugar mas antiguo de la ciudad, aquel que los historiadores reconocen como el núcleo fundacional de la ciudad y colocar allí la imagen de un ciudadano recién llegado, un bebe; a esta localización se sumarían otras, la última casa construida tendría como estandarte la imagen de un/a anciana de la ciudad, los ciudadanos fotografiados podrían proponer localizaciones específicas que tuvieran que ver con sus vivencias. Buscábamos este tipo de relación entre los ciudadanos con los lugares de la ciudad que habitan, espacio-ciudad/ciudadano-memoria, de los ciudadanos en 
relación con su experiencia de lugar y con el espacio público. Todo el proyecto dependía de la complicidad e implicación de los ciudadanos, no todo el mundo quiere ser fotografiado y expuesto públicamente. Finalmente, delimitamos el proyecto al edificio del ayuntamiento por la dirección connotativa que ello habría de suponer: durante todos estos días la imagen institucional, o si se quiere, la relación imagen-ciudadinstitución ha correspondido como representación a los ciudadanos.

Una intervención, en el caso del espacio público, tiene que ver de partida con el hecho de trabajar en/y con el conjunto del espacio público puesto en cuestión. Intervención, dicho en el sentido de una estrategia plástica de saber y de conocer, nada tiene que ver con el acto de "plantar" un objeto -artístico o no- en una calle, una plaza o un entorno rural, una intervención tiene que ver en su fondo profundo con el ámbito complicado de la cosa tanto como con su ámbito simple: toda estrategia de intervención es siempre una estrategia de colaboración; se trata de abordar el contexto específico de actuación desde la perspectiva de una interrelación aportativa entre el ámbito señalado para intervenir y la dirección discursiva de quienes intervienen, cosa que en su fin último, incluso al margen del necesario o no despliegue estructural, siempre tiene que ver con una expresión necesariamente cohabitativa. La distancia, siempre operativa en tanto tiene que ver con modos y formas de hacer, entre las estrategias plásticas de intervención y las estrategias plásticas de plantación (de enclavar el gran objeto o el conjunto de ellos, dados de antemano por extraordinarios) tiene lugar en la forma de interrupción la experiencia cotidiana de unas, en este caso las últimas, y el sentido colaborativo y de continuidad de las otras, o sea de las primeras. 


\section{A.23 DE LA IMAGEN: LO QUE NOS MIRA}

Cuando de algún modo decidimos pensar la imagen lo que de ese modo queremos decir es pensar en común, pensar la colectividad de la imagen y los esfuerzos colectivos de su producción. Pensar en común es suponer la imagen como una relación colectiva [de rozamientos directos e indirectos], en tanto todos y cada uno de nosotros forma parte, al menos en éste occidente historizado y tecnológico, de la estructura y del paisaje que define, bajo las mismas leyes perceptivas, nuestros actos de ver $\mathrm{y}$, por lo mismo, el ámbito, los niveles y flujos primarios de (como actividad humana) nuestra visualidad: de aquello relacionado - que fue o esta siendo- con el 'qué vemos' (porque lo producimos), con el 'cómo lo vemos' (por cómo lo disponemos o distribuimos), 'hemos visto o veremos' (por cómo historizamos la cosa), o con el 'qué pensamos' de lo que de algún modo hemos visto (cómo filosofamos).

Somos [nosotros] imágenes y medios, y vehículos-portadores —en claro proceso de simbiosis con la máquina- de medialidad que comportamos decisivamente las direcciones semánticas de la casi totalidad de las imágenes, incluyendo tanto las exteriores como las interiores, y las no visibles como también las visuales. Esto es, ellas son lo que nosotros, sus mediadores, hemos decidido archivar y hemos decidido que sean, pero no por voluntad radical ni posición de poder, sino por la doble naturaleza que, en este caso, nos defines: cuerpo e imagen, eso lo que puede llegar a ver y eso lo que puede ser visto. En la actualidad pensar la imagen es una tarea harto complicada porque las cuestiones referentes a ella están relacionadas no sólo con el ámbito del arte sino sobretodo con los medios [de los que somos o bien parte o bien analogía] y con dispositivos casi autónomos de distribución; dispositivos que describen los pasos $^{22}$ de la imagen, en el cada vez más intenso y poblado paisaje de cruces e intercambios que en relación a ella está teniendo lugar. Lo cierto es que lo que entendemos por realidad de la imagen (asociada únicamente a lo visual), en sentido estricto no lo es, puesto que viene a ser en gran medida sólo el conjunto 
que hasta ahora hemos entendido y podido explicar, sólo lo poco que de ella hemos podido archivar y distribuir. Sin embargo, aún en mayor proporción, todo aquello que se ha quedado fuera de lo que hasta entonces constituye ese archivo de la imagen, no cuenta para su definición, y por ello, como realidad de la imagen. Así, la idea de imagen es un $\operatorname{archivo}^{23}$ relativamente pequeño en relación a la realidad de la imagen, que abarca todo lo que no hemos decidido entender ni llegado a comprender de ella, y por lo mismo, no hemos llegado a registrar como imagen de la experiencia o, por definición práctica, como archivo casi definitivo de la imagen. Sin lugar a duda, hoy por hoy, la imagen es más imagen de la misma manera que es más acto de igual modo que más $\operatorname{cosa}^{24}$, aunque, y esto es de importancia relevante, en relación a las otras anteriores eras de la imagen, con la sustancial diferencia de que los hombre participan más en los actos de su distribución y archivación que en los de su producción, cedidos en gran medida a los nuevos medios y dispositivos. Imagen y medio forman una relación conveniente [de convenientia], aún habiendo una sustancial distancia, una separación determinante y también conveniente, en cuanto a la orientación funcional de dicha relación tanto para la mirada, que para la inscripción de significaciones, entonces, diferentes. Generalmente el medio soporta a la imagen en la misma medida que le aporta un cierto grado de nuevo contenido conceptual: que le cede un porcentaje reorientativo a la carga prehistórica arrastrada por la imagen en transito. Esto, puntualicémoslo, es sólo referido a la relación imagen-medio en el ámbito del arte, cosa que, sin duda alguna, es bien evidente. En otros niveles o resortes de la imagen, la proporción y relación es bien distinta. "La distinción entre imagen y medio nos aproxima a la conciencia del cuerpo"25. Pensarla (las imágenes), por lo tanto, debería liberar más de una dirección de aproximación a su naturaleza y, de igual manera, a los múltiples medios (entonces lugares del cuerpo de la imagen) que

23 Groys B. "Bajo sospecha: Una fenomenología de los medios". Ed. Pre-Textos. Valencia, 2008. España.

24 De la frase de Sartre "acto de igual modo que como cosa", citada por Hans Belting en el prólogo de su libro Antropología de la imagen. Ed. Katz Editores, Madrid 2007. España.

25 Belting, H. Antropología de la imagen. Ed. Katz Editores. Madrid, 2007. Pág. 17. 
atraviesan, y en los que se archivan o en los que se almacenan haciendo posible su percepción, y que abarcan desde la mente hasta los artefactos y procedimientos con los que son obtenidas y que necesariamente relacionamos también con imágenes. De manera casi general la pregunta sobre la imagen (o el conjunto de ellas) no ha tenido lugar. Bien porque (¿la pregunta?) augura una respuesta sobre otro ámbito de cosa o bien porque suplanta —al estilo de ¿Qué es esa imagen? - a la filosofía como objeto de estudio. En ese sentido es lo mismo la pregunta sobre la imagen que sobre el estado de la filosofía, o sobre cualquier otra cosa. Sin embargo, lo embarazoso de esto no es que ambas preguntas se suplanten (quizás debería referirme a usurpaciones) en una acción casi recíproca los objetos profundos de una y de la otra, sino que sobre ambas muy poco se puede decir porque ni una ni la otra atraviesa (ha construido, inventado o llegado a ser) una posición de problema, cosa que en el acto las convierte en una generalidad de la que sin pensarlo hay que escapar. La cuestión estriba, en todo caso y dada por consumada la 'escapada', en la fabricación audaz de problemas sobre (y en torno a) las imágenes, los medios y los dispositivos generadores de imágenes y de visualidad, en la fabricación de problemas en torno al devenir-visualidad de las imágenes o a ese, entonces, estado de ser que no se confunde con el inicial devenir-visualidad. Así resolveríamos [debería resolverse] sin dificultades insuperables y siempre en direcciones útiles (en tanto que, siempre, se activaría un proceso-motor, en su condición premnemónica), cuestiones y trastornos derivados de herencias sintagmáticas erróneas en la cadena conveniente y relación de progresividad entre "la imagen" y el "devenir-imagen". Resuelto esto, la primera necesita ser extendida en la segunda, y la segunda, extensión de la primera. En ese sentido debería entenderse algo así: 'Cuando veo una imagen, lo que veo es un proceso en aparente culminación'. En este punto, una imagen pensada en una relación de doble captura (quizás de evolución a-paralela, como dice Deleuze recordando a Rémy Chauvin), o en plena progresión "ser-devenir", sería, porque de igual modo lo es, la relación 'escucharvisualizar' que en sí es más compleja y completa que el estimulo inicial de la que ha devenido. En la imagen sólo nos detenemos (y aquí pensemos, aunque no como el ejemplo perfecto, en tanto se refiere sólo 
a una impresión de movimiento en la imagen derivado del efecto fi, en la esquematización dada en el cine en relación a la estructuración de la idea de temporalidad o bien en el comportamiento de la imagen-tiempo), cuando antes ha habido una suplantación de otra que en su haber sido guardaba una extraordinaria y progresiva similitud con la que, en todo caso, proyectamos y a la vez protegemos; sólo cuando la que encarna nuestro detenimiento ha suplantado a su igual prehistórica y progresiva aunque, entonces, como algo diferente - cuando sobrepasada la línea de la linde, o la amenaza y la conversión de ésta en el problema-motor [en la ipseidad de la imagen que en cuestión es] ya ha tenido lugar de modo irreversible. Las imágenes por más simple que sean en apariencia, en si mismas no son formaciones elementales, sino progresiones complejas y problemáticas que hacen [dan en su impronta] algo más que transmitir las condiciones de meras experiencias de sensorialidad: ponen en cuestión nuestra idea, expectativa y experiencia del ver, tal cual la amenazadora llamada de atención 'no soy lo que ves, sino el origen estructurado y diferante de las diferencias, soy eso que te mira ${ }^{26}$. La imagen tal cual el 'origen' no es la "fuente" del hecho comprobado, no es la génesis, sino una referencia a su prehistoria y a su posthistoria. Ellas nos miran, nosotros desearíamos haberlas visto.

26 "La diferencia (différance) es el 'origen' no pleno, no simple, el origen estructurado y diferante de las diferencias. La palabra 'origen', por lo tanto, ya no le conviene", J. Derrida, "La différance" (1968), Marges - De la philosophie, París, Minuit, 1972, pág. 12 (Trad. Cast.: Márgenes). 


\section{A.24 EVE SUSSMAN \& RUFUS CORPORATION}

Las herramientas de las prácticas visuales y artísticas varían según el caso. El lenguaje visual es de alguna manera la caja de recursos común de la que todos sacan lo necesario. Sin embargo, a pesar de esa caja común, siempre hay algo que distingue a unos de otros. En el caso de Eve Sussman \& Rufus Corporation es, antes que cualquier otra cosa, la forma de organización del trabajo, de impulsar sus producciones. De lo imaginado. Cuando las producciones de Eve Sussman \& Rufus Corporation son relacionadas con la pintura por el sólo hecho de que alguna vez trató sobre ello, debería pedirse disculpa a la pintura. La asociación que en este caso se hace puede que provenga del acercamiento, entre líneas, a ciertas memorias temáticas -llámense ordenaciones o comportamientos históricos, conjuntos de historias, psicologías o generalizaciones aproximadas, y sólo aproximadas, al ámbito de la pintura-, que, en su lugar, se vinculan consigo mismo y con la libertad de lo que propiamente en el nuevo ámbito, y nuevo acercamiento, están descubriendo: memorias que de algún modo son el devenir resultado (casi en el sentido de la idea del Museo imaginario de Malraux), y no otra cosa, del conjunto de las prácticas reales e históricas de la pintura, cuyo desborde mismo niega rotundamente (por su naturaleza y por lo que resuelven) la objetividad de esa asociación, que en este caso, de manera injusta, parece haber tomado cuerpo, alentada por ese extraño entusiasmo e influjo retórico que en torno a toda novedad discursiva siempre crece. Para hablar de relación con la pintura en las producciones de Eve Sussman \& Rufus Corporation, deberíamos hacerlo en términos de relaciones indirectas: no en la proximidad de la verdad objetiva de su historia porque, como es obvio, sería imposible, sino en su preferencia y aceptación como ficción existente en torno al acontecimiento pictórico; deberíamos hacerlo, si se quiere, en términos de una nueva problematización de la relación entre la experiencia estética y la experiencia histórica o en relación a las nuevas formas de enfocar el uso "estético" de la historia, pero también, cosa que de algún modo abre una muy fértil brecha reflexiva, en términos de la necesidad de integración 
del individuo artista en los nuevos grupos de acción y estrategias comunitarias, y ello, en relación a las nuevas direcciones teóricas, filosóficas y prácticas de los nuevos colectivos de acción creativa; tal vez, deberíamos hacerlo en términos de "la cosa crecida en medio de $^{\prime \prime}$, de la relación estrategia-producciones finales gestada justo entre dos ámbitos igualmente fértiles: uno que comprende toda la memoria histórica, y otro que, entonces conteniendo parte de esa memoria, abarca este presente acelerado, de accesos y tecnológico; todo lo contrario de un acercamiento apresurado y ligero a la relación Eve Sussman-pintura histórica, de la aproximación superficial a la pintura en sentido general y a las producciones de Eve Sussman en particular: la gran pintura histórica vs las producciones de Eve Sussman, pero en términos de veneración y en la dirección de la cuestión museo-colección-templo, amen de una complejidad mucho más intrigante, nacida de este tiempo -de grandes economías, tecnologías diversas y de la globalización-, puesto en entredicho por el presente mismo. Inicialmente a Eve Sussman \& Rufus Corporation debería entendérsele en el filo ideológico de las formas cinematográficas de gestión productiva y entonces después como creadores de macroconfiguraciones histórico-visuales o como registradores excelentes [sobre todo en soportes como el vídeo y la fotografía, aunque con técnicas rigurosamente cinematográficas] de largas improvisaciones que entrecruzan el teatro, la performance y la música; quizás, primero como introductores de intertextos videográficos en grandes relatos clásicos, y luego, por sus intentos de transferencias -y reconstrucción crítica- de la pintura histórica a la imagen en movimiento, como también, por sus tentativas de representación de la historia y la reactivación de la alegoría y los modos de producir simbolización, o como creadores de superproducciones a escala de las grandes galerías y de los más importantes centros de arte. Entendérsele así no sólo lo hace posible la dinámica del momento en que vivimos -al borde mismo de la entrada en la era del acceso, como apunta J. Rifkin, y de la revolución de la nueva economía-, sino que lo exige: ya no puede leerse ni interpretarse actividad alguna al margen el tejido económico y tecnológico que nos acoge, como tampoco puede proyectarse iniciativa alguna fuera de ello. La formación histórica 
de nuestro tiempo, como todas las formaciones anteriores y de sus tiempos, da a ver -como recuerda G. Deleuze- todo lo que puede, como del mismo modo y en correspondencia lo social [que también ello somos] se da a ver y se enuncia. De ninguna de las maneras, y menos a través de un distanciamiento teórico, que siempre es peligrosamente reaccionario, podemos desplazarnos (tal vez separarnos) del líquido mismo de la actuación: en todo caso ese distanciamiento, esas separaciones y esas abstracciones, serían siempre definitivas, y en tal sentido, irreversibles e insalvables. Los límites económicos de una configuración cultural guardan siempre una igual correspondencia con los límites de su proyección artística y, en esa misma dirección, de su producción simbólica. Necesaria es por lo tanto una cierta pedagogía en torno a la relación economía-práctica artística: que apunte y visibilice su traducción constante en actos del día a día, y así, el conjunto de las cadenas de operaciones transaccionales que toda práctica [no sólo la artística] supone. Asumimos entonces -y esto, como es obvio, afecta también al conjunto de las prácticas de producción simbólica (el autor, en el escenario que le corresponde, es primero receptor y consumidor de las producciones y las economías que le anteceden y luego productor y emisor de sus re-creaciones)-, que el conjunto de los dispositivos y recursos disponibles, incluidas las ideas y las experiencia, son también producciones anteriores [bienes físicos y simbólicos], mercancías particularizadas, expuestas de modo similar a los productos básicos en los grandes almacenes y mercados pero esta vez en extendidas superficies culturales o transculturales de las que para su uso y gestión pagamos constantemente, tengamos clara conciencia o no de la transacciones a las que asistimos. Toda práctica artística es por lo mismo una práctica económica: una inmersión en el líquido económico de su tiempo, que no debería, cosa que a menudo sucede, perderse de vista. Todo el despliegue y gestión que conlleva la producción de obras como "89 SECONDS AT ALCAZAR" (2004) o "THE RAPE OF SABINE WOMEN" (2006), es también, desde el inicio mismo, pura y dura discursividad. Discursividad que aquí debería entenderse como un devenir constante del trazado proyectual de las obras en otro grado también [ampliado] de discursividad -de ser, entonces, construcción 
progresiva e instrucción de lo visible o dado por ello-, y alejada del sentido postmoderno-pragmático que nos conduciría únicamente a un examen retórico de la cuestión. Los preparativos de inicio (inversores financieros, sponsorización, investigación, composiciones musicales, la puesta en escena, las locaciones, etc.), que bien podríamos suponer como una extraña y particular performance, guardan la misma relación de importancia que la exhibición final de la vídeo instalación o fotografía; aunque, como es cosa evidente, todo ese complicado recorrido constructivo sufre, a veces de manera imperceptible y a veces de manera notable, numerosas y necesarias oscilaciones de significación (de eso lo trascendente de la cuestión) y de orientación del significado (de la necesaria materialización iconológica del conjunto de los conceptos problematizados) que garantizan la configuración última del cuerpo temporal, conceptual u objetual de la obra, como por ejemplo algunas alteraciones del contexto práctico o de los lugares dados para la actividad común (si se quiere, espacios progresivos de colaboración y exhibición), o simples variaciones en los usos del conjunto del instrumental necesario y del conjunto de los dispositivos dispuestos para la gran producción, etc. Así, la forma de relacionar [o relacionarse con] esos dispositivos e instrumental que, en principio, parecen apuntar hacia una suerte de reprocesamiento del conjunto, -al estilo de las experiencias de los $\mathrm{Dj}$ de los años '80-, deviene en dos modos de gestión paralelos: por un lado, la gestión creativa, de la que hablaremos luego; y por otro, la gestión empresarial, en toda la extensión del término, en tanto que el tiempo de elaboración del conjunto de la obra [y aquí asúmase obra en el sentido de una experiencia única que necesariamente tiene que rentabilizar la inversión inicial] puede traducirse en horas de trabajo, inventario de medios y fungibles, trabajo especializado, mano de obra, etc., y todo ello, entonces en dinero, empleo y en una eficaz labor administrativa. Eve Sussman \& Rufus Corporation podría entonces pensarse conformada como una empresa-red: tal cual una productora cinematográfica cualquiera, si bien por definición no lo es; cuyo dinamismo cooperativo fluctúa según la duración y las necesidades del proyecto.De la imagen. Detrás de la poderosa progresión y calidad de "THE RAPE OF SABINE WOMEN", el vídeo-musical de Eve Sussman \& 
Rufus Corporation, que recientemente ha sido expuesto en la sala San Esteban de Murcia, no puede haber otra cosa que no sea una cuasi industria [un empresa creativa que al mismo tiempo es consumidora, motor y motivo de síl, una congregación post-productora con mayúscula, y por lo mismo, muchísimo dinero, generalmente llegado de mano de los inversores financieros y los múltiples sponsors. Hablamos, por lo mismo, de una estructura de gestión articulada, si no igual, al menos como algo parecido a una empresa. Ahora bien, qué significa todo esto. Pues, significa muchísimas cosas, aunque básicamente una afectación decisiva en relación a las prácticas plásticas y visuales actuales y una alerta -en tanto que impone otra pedagogía y otra economía-, de cara a las prácticas de un futuro inmediato, que tiene que ver con la naturaleza profunda de la obra, de sus ejes constructivos y de su gestión, y, en ese sentido, con la naturaleza misma de toda práctica por ser: ya ni la obra ni las prácticas pueden ser pensadas en los términos en que se pensaban las bellas artes (según la topología social, material y semántica de la Edad Clásica de regulación y reproducción del sentido y de las funciones de las imágenes, de las palabras y de las cosas) "la cosa devenida a través de la mano del artista-genio en objeto artístico y estético, en objeto casi superior", en tanto que la gestión y la especificidad de la experiencia de lo visual [la nueva importancia de su sentido], y de lo artístico, ya no es lo que antes necesariamente fue; ahora, por definición, es mucho más, es colaborativa y, en ese nuevo ser, más libre en su indefinición: más espacio de libertad, en tanto que, teóricamente, se presume asumido el conjunto de las especificidades. Del hacer y la práctica. Experiencias como las de Eve Sussman \& Rufus Corporation plantean y hasta cierto punto resuelven la cuestión de que no basta con una buena idea, sino con un espacio óptimo de colaboración, mucha labor acumulada, un sinfín de instrumentos de producción y toda una cultura de objetos para ser post-producidos. Hoy por hoy, toda proyección discursiva que pretenda alcanzar los más altos niveles de eficacia, utilidad, efectividad e intercambiabilidad -de cara a la nueva y exigente comunidad de receptores-consumidores de producciones visuales y artística-, ha de ser necesariamente pensada, si no como una maquinaria (cual potentes motores premnemónicos, pero estos conectados de algún modo a la 
máquina-herramienta real de la tecnología y de la industria), al menos en relación orbital con ella; pensada, como una factoría cuyos resultados artísticos-productivos también han de guardar una más que estrecha correspondencia con los modelos relacionales de gestión, calidad y productividad de las grandes corporaciones o empresas, y por lo mismo, contar mínimamente con una particular estructura gerencial que satisfaga y gestione, no sólo los instrumentos y bienes de producción creativa y los niveles de dependencia (o no) de inversiones de capital a mediana o gran escala, sino también las relaciones colectivas de producción que [hoy en día] suponen una más que elaborada división del trabajo. Sin embargo, no se trata de la correspondencia en los modos estratégicos de distribución (que en algunos casos tiene evidente y visible lugar, en tanto que, en el mismo acercamiento a la relación, dicha correspondencia ha de ser necesariamente intuida), se trata más bien de la correspondencia en las formas de uso de la materia prima, del uso corporativo -y por extensión discursivo y en comunidad- de todos y cada uno de los canales proveedores de materia prima de calidad y de todos y cada uno de los canales aseguradores de dicha calidad. Esto es, el entendimiento corporativo de la naturaleza de la obra y de los procesos de producción [democratización] y uso de las imágenes: en el caso de Eve Sussman \& Rufus Corporation la técnica no es el tema, como es evidente, pero si el resorte inicial o base de utilización de la naturaleza procesual de sus propuestas. Cuando Eve Sussman \& Rufus Corporation realizan un proyecto como "THE RAPE OF SABINE WOMEN", redibujando la idea de la naturaleza de la obra, incluso al margen de una no-conciencia del propio redibujo de esa naturaleza e incluso al margen del conjunto de retóricas necesarias que de alguna manera moldean el discurso, han obrado como teóricos al tiempo que como artistas visuales-realizadores, en tanto que con la resolución de la "idea de obra" han resuelto también una cierta idea de la "naturaleza de la obra" misma: han producido una ruptura definitiva de su epidermis. La empresa como proyecto -sus trabajos no sólo incluyen cine, vídeo, instalación, escultura y fotografía, teatro, música, performance, sino todo un esfuerzo administrativo y de gestión, al estilo de las medianas producciones cinematográficas o de publicidad- $\mathrm{y}$ entonces como 
práctica visual y artística, es con Eve Sussman \& Rufus Corporation todo un hecho destacable pero no sólo por resultados como el de "THE RAPE OF SABINE WOMEN", sino por su interés colaborativo y por la forma de organizar la colaboración imprescindible, colaboración necesaria (Bobby Neel Adams, Popi Alkouli-Troianou, Themis Bazaka, Kostas Beveratos, Nesbitt Blaisdell, Marilisa Chronea, Ricoh Gerbl, Stergios Ioannou, Grayson Millwood, Katarina Oikonomopoulou, Benedikt Partenheimer, Helen Pickett, Annette Previti, Rosa Prodromou, Claudia de Serpa Soares, Walter Sipser, Antonis Spinoulos, Christos Syrmakezis, Sotiris Tsakomidis, Jeff Wood, Savina Yannatou, Karen Young y Sofie Zamchick) y, por lo mismo, las relaciones de producción creativa del colectivo de turno y la división notable del trabajo -artistas intérpretes o ejecutantes, artistas y músicos. El vídeo, estructurado en cinco partes, empieza en el Museo de Pérgamon de Berlín y transcurre entre la S-Bahn, el aeropuerto de Tempelhof, el mar Egeo y finalmente el Herodion Theatre de Atenas. En él, eso que parece una reinvención (¿renuncia?) del relato original, y entonces del mito sobre la fundación de Roma por Rómulo, no es más que un doble acto: a la vez de extracción y recolocación -cambio del continente- de dicho relato no sólo en los nuevos emplazamiento y locaciones sino en un soporte cuya naturaleza espacio-temporal lo proyecta, tal cual la propia dinámica de los soportes videográficos, hacia una inmediatez que evidentemente nos corresponde. La ordenación y estética de "THE RAPE OF SABINE WOMEN" -en la que subyacen vestigios de las experiencias del absolute film (o cine puro) de las vanguardias históricas, y por ello, de sus intentos de conexión estructural con la música y de sus tentativas de búsqueda de un "ritmo visual puro", como también de la memoria de los experimentos de Film Estructural de Sitney y su interés por la duración y la estructura como determinantes del contenido-, guarda, aunque redimensionada, una similitud con las ordenaciones y estéticas narrativo-discursiva del vídeo-clip, con la sola diferencia de cambios, bastante notables, de temporalidad (si entonces, en los experimentos de Film Estructural el fotograma era la unidad mínima de significación, el frame -como la unidad mínima del clip-, es con el HD esa unidad de significación aunque, eso si, extremada en el uso como determinante del tiempo 
videográfico) que llega a aproximarse a los niveles más comunes de temporalidad cinematográfica, su linealidad secuencial así lo es: reportaje-ruptura-narrativa-alegórica-ficción-efectos visuales-ficciónruptura narrativa-alegórica-ficción-ruptura narrativa-efectos visuales. Notable es ese cambio de tiempos, hasta tal punto, que llega a eclipsar toda la memoria estructural videoclip total (o vídeoFilm) y a poner en crisis la narrativa inicial, la del relato pretexto, o si se quiere, la del mito de partida; todo ello evidenciado no sólo a través de las calidades HD sino de la simulación y de los tiempos, de la comprensión numérica (manipulable) del tiempo videográfico: el registro inicial puede ser perfectamente descompuesto en secuencias de imágenes y cada imagen duplicada, y cada copia intercalada en la nueva unidad secuencial derivada del registro inicial. Así, lo que se cuenta, lo asumido y hecho visible por las imágenes -entonces, la materialización secuenciada e iconológica del concepto/relación "relato del mito de la fundación de Roma o "THE RAPE OF SABINE WOMEN"-, no sería posible sin la manipulación numérica que el propio soporte admite y que le aporta, una vez resuelto como relato videográfico, la dimensión y extensión de una información que es posible leer como estética, y por ello resemantizada. Lo que parece decir, mejor insinuar, es que no hay como tal recreación. En todo caso, y si bien implícita, la cuestión de la relación pasado-presente no es, digamos, la preocupación central, sino la del uso como imagen -cual materia prima abundante- del patrimonio cultural y el legado artístico (y literario) en una nueva o actual relación. Teóricamente, al estilo de Nicolás Bourriaud, es posible justificar esa relación pasado-presente, sin embargo, desde la práctica misma, el uso de dicha relación tiene que ver más con cuestiones de/o sobre la naturaleza de la obra, que cualquier otra aseveración, como por ejemplo: el paralelismo metafórico con la pintura. Dicho de otra manera, en las últimas producciones de Eve Sussman \& Rufus Corporation lo más importante (y un peso evidente si que tiene en la estrategia de construcción discursiva) no es exactamente el resorte temático o retórico, sino el despliegue relacional: el todo colaborativo o conjunto que participa desde el inicio hasta el escenario estructural final [por ejemplo: los bloques creados a base de improvisación, el sonido 7.1, las 
180 horas de grabaciones en vídeo, las 6000 fotografías, la elaboración de composiciones musicales y de sonido, la incorporación de un conjunto buzuki, un coro toses de Pérgamon y un coro de 800 voces] y por ello, la naturaleza de la obra que, como hemos dicho anteriormente, y en todo caso, es corporativa. "THE RAPE OF SABINE WOMEN" es, si es que así puede decirse, una producción consistente. Pero lo es, más que por lo que nos satisface y extraña, por el pensamiento que traza: el de la asistencia cómplice a la conformación -y todo esfuerzo colaborativo es siempre cualitativamente superior al no-colaborativo-, de una relación de intereses y de historias, de valores agregados y de intertextualidad (en el sentido de la copresencia de Genette), de distanciamientos brechtianos y de tiempos que surgen desprovistos del movimiento en la superficie de retroproyección, pero sobre todo, a la conformación de una extraordinaria experiencia de mirar, y de ver el mito mismo, de la que también somos relatores determinantes: quizás los relatores que en la colaboración (en la Corporation) definimos la orientación crítica (no la poética que, como imagináis, es cosa de Eve Sussman \& Rufus Corporation y de ciertos juegos retóricos y de autoimágenes), y tal vez, la ordenación y completamiento del discurso: donde ya el conjunto de los esfuerzos ha devenido legítima discursividad. 


\section{A.25 JAVI MORENO: EN ESE NECESARIO VÉRTICE CREATIVO}

Lo nuevo en el arte, igual que en la filosofía, comienza con una experiencia de desencanto, con una insatisfacción ante lo que hasta entonces, respecto al algo que se quiera, se ha dado y supuesto como un orden definitivo, como norma (jerarquía de valor, demandas y expectativas) entonces a seguir (o seguida) ya sea política, religiosa, artística o filosófica. Comienza, por tanto -y en este contexto entiéndase experiencia de desencanto no como rabieta juvenil sino más bien adscrita a la condición descubrir-reconocer como una clara posibilidad-, cuando el crepúsculo de nuestros ídolos, amados o no, y de las ordenaciones que nos atañen se ha convertido en una más que extraordinaria evidencia. Entonces deviene el arte, la discursividad y su práctica. Lo que básicamente impulsa a los artistas jóvenes a producir creativamente sus obras es la relación que se produce entre esa experiencia de desencanto y la necesidad desbordante de producción de lo nuevo. Javi Moreno es joven (Alicante, 1982) y además es artista, cosa que no esta nada mal y que lo sitúa en ese necesario vértice creativo no siempre dado a todos. A primera vista sus obras parecen refugiarse en los modelos, formatos y estándares constructivos habituales, pero todo ello es sólo una mera apariencia tras la que toma cuerpo una poderosa reflexión sobre el uso mismo [no en el sentido temático, claro está] de esos propios estándares pero, entonces, como posibilidades críticas: si distinguir lo nuevo auténtico de lo nuevo inauténtico es cosa prácticamente imposible, eso no impide -encajados en otro flujo de discursividad- que su nueva reordenación y orientación hacia territorios críticamente activos del pensamiento social y de las prácticas actual del arte nos sea devuelta como un producto 'imagen-llamada de atención' resuelto a dar voz, significas y valor a las nuevas y grandes problemáticas del individuo y de las sociedades de hoy. El dato es la imagen de lo que la cultura técnicamente archivada contiene. Lo que de algún modo da cuerpo y valor al conjunto de la obra de Javi Moreno no es, como generalmente se piensa, la orientación temática de cada problematización aborda por él, sino más bien -entonces en el sentido de una reutilización discursiva de la red y sistema de datos y archivos universales o locales 
y de la cita por tanto del conjunto de los datos de la cultura existente, de la comunidad cultural con la que dialoga-, la puesta en cuestión de la naturaleza (en cada caso) de ese recurso tomado para dicha problematización. Esto es, que en aquello que ofrece como experiencias de desencanto cada recurso tomado por él, cada recurso de la cultura existente en dialogo con él, aguarda [en ello] una posibilidad otra de problematización, o lo que es lo mismo, una práctica posible. En ese sentido la obra e investigación de Javi Moreno en torno a los procesos de construcción de la masculinidad y la conformación casi traumática de la identidad ha surgido -artísticamente hablando- de esa experiencia de desencanto. Sin embargo, y aunque en relación con el conjunto de esas ordenaciones normativas que arriba describo, la naturaleza de ese desencanto con el que relacionamos en última instancia la obra de Javi Moreno, deberíamos encontrarla asociada, en su fondo y origen profundo, a la religión y a la política (y de forma extendida a la moral y la ética): a la religión por que suscita el problema del sentido, y a la política porque suscita el problema de la justicia. Sentido y justicia en relación, pero sobre todo en cuanto que el primero se refiere a la ausencia de fe (en algo localizado) y el segundo de cómo ésta [la justicia] puede o ha de hacerse efectiva. El desencanto artístico, que hace posible el surgimiento y práctica de nuevas orientaciones discursivas, nace del descubrimiento de que los estándares del arte mismo -de lo institucionalizado y no del conjunto de las poéticas que los piramidan- ya no son capaces de dar (suponiendo que alguna vez lo hayan sido) sentido a la vida humanamente artística. En ese sentido la obra de Javi Moreno comienza, digamos que de forma indirecta, con el reconocimiento de la imposibilidad de dar crédito a dichos estándares y, al mismo tiempo, con el erosionamiento (en tanto se da a sí misma como problematización y como novedad) del conjunto de las estructuras, economías y modelos de discursividad que entonces le han antecedido. En este contexto sus obras (pinturas dibujadas, dibujos pintados, manipulaciones videográficas, instalaciones habitables y performances) dan forma crítica a otra manera de observación de la economía productiva de la nueva obra, entonces sobre la base de un imperativo ético que le permite posicionarse, también críticamente, en 
el panorama de una nueva visualidad y una nueva práctica de saber. Del trazado progresivo de los márgenes de un juego de lenguaje otro - tal vez de una novedosa escritura-, o si se prefiere, de la puesta en observación de cada uno de los puntos de interrelación que la amplísima variedad de experiencias visuales actuales le ofrece, y de cuya variedad misma Javi Moreno extrae y da forma a su particular modo de práctica, es, sin dudas, de lo que se trata. 


\section{A.26 SOBRE Mineralidad ABSOluta/ RETRATO OTRO DE JOsÉ LUIS BREA}

Soy un Dios celoso. No habrá imagen “... ni ninguna semejanza de lo que está arriba en el cielo, ni abajo en la tierra, ni en las aguas debajo de la tierra. No te inclinarás ante ellas..."27 Imagen-eternidadsospecha. De lo que estoy completamente convencido es, allá donde se encuentre, de la sonrisa sobrevenida en el rostro de José Luis Brea al contemplarnos sobrecogidos, patéticos y entre elogios ante la lectura de su último ensayo -publicado después de su muerte, pues así había sido su deseo- y con el eco, aun en el cogote, de la macabra sublimidad del re-publicado "Los últimos días", entonces ya no como recuperación memorable, cosa que en toda regla podría tener algún sentido, sino como conciencia de un estado por ser en breve, que en su caso, y con total naturalidad, era lo que en su filoso humor contaba. "Todo estaba bajo control", se diría por tanto, aunque bajo el supuesto (y de ahí la sonrisa y el enigma posible) de que los vínculos conectores de la triada "escritura límite, modelo crítico e imagen", no han sido del todo percibidos y menos aún la docilidad que conjuntamente portan, venida, en su fondo profundo, de un saludable respeto por las cosas de la visualidad y de una economía -como trazado base del (su) gran proyecto emancipatorio- radicada en la mirada. Se trataría por tanto de eso y no de ninguna otra cosa más. Una economía de la mirada que remita a un imaginario que, a su vez, evoque una realidad entonces crítica, es lo que necesitamos. Leer un texto no es simplemente describir lo que creemos descifrar en el, entregándonos -hartos de pasividad tal vez- a una interpretación complaciente. En todo caso, lo conveniente sería - pues de lo contrario nunca estaríamos haciendo una real economía de la mirada- remontar la corriente de los sentidos que al texto, como territorio problema y vínculo en el que se fundan todas las imágenes que contiene, previamente se le ha dado. El ensayo en cuestión se titula "Mineralidad absoluta (el cristal se venga)". Un ensayo escrito para iniciar la cerrazón necesaria de la anti-imagen por ser. Cerrazón de

27 MELOT, M. Breve historia de la imagen. Ediciones Siruela, 2010. Madrid. España. 
una figuralidad antípoda, siempre pulsada -de aquella que no remitiría, que dejaría de hacerlo, pues la físicidad y los vestigios estructurales que, en todo caso, necesitaríamos para tal aproximación, habrían sido sabiamente minadas y (con toda suerte de mesías relojero) previamente desmanteladas y disueltas. Toda vez que pretendamos el culto, la antiimagen -que en el engranaje está dispuesta no para otra cosa sino para consumar el propio suceder histórico- cobrará su justo sentido, y así, la trayectoria otra necesaria. Nunca habrá aproximación, propiamente dicha, pues la anti-imagen es también la imagen que se potencia a sí misma al tiempo que la potenciación deviene celosamente autonegación, y en tal sentido, creación, redimir, consumación. La imagen ha de temer a la imagen para entonces poder ser en la propia desaparición. El eco es la simiente del eco. Todo lo análogo -trabado, en principio, en una más que probable vulgarización de uno de los polos que lo tensionan y que le otorgan rango de semejanza, basado por tanto en una relación sensible con todo aquello que de alguna manera a él lo representaríaentraría en conflicto con el juego de códigos, las batallas críticas, la idea de felicidad y la puesta en común de un sofisticado sistema de conceptos críticos, cuyas claves sería preciso tener -la parte, por tanto, de código convencional de toda imagen o anti-imagen, como afirmaría Melot-, y que por ahí andan (entre papeles y mentes) en forma de acertijos o como complicadas y resbaladizas ecuaciones. Conocedor del potencial crítico del uso de la imagen, ha dejado esbozado -un flujo que va y vuelve una y otra vez al "¿en qué se convierte aquello sin imagen?" que pregunta Melot, y a un sin fin de ruidos ocultos y secretos- un peculiarísimo sí mismo, amen de si tuviera lugar aquello de la mirada de reojo o el yo propietario, que jugaría su papel únicamente (firmado el relato y concluida la escritura) como mirada vigilante de la que ninguna representación ni nadie podría dar cuenta jamás con la nitidez necesaria, a menos que sea como apariencia de un algo abstracto sólo conocido de oídas cuya comunicación, conectividad e incluso feedback, lindarían con finitud y escrituralidad. Tal vez ha querido decir -y aquí, en su volver, la idea de mineralidad es un anteponerse traslucido, una transparentalidad progresiva hacia la petrificación- al estilo de las frías sentencias aguardadas en los libros carolinos e incluso con la 
certeza de que ello no impediría que las desviaciones fueran inevitables ni que, al margen de todo, verdaderas, amadas y amorosas lágrimas fueran vertidas. Quizás dijo -entonces como perfecta cristalización de la relación "idea de felicidad-proyecto intelectual", entonces como diamantización de su ser intelectualizado-, autorizo la imagen y su apariencia, pero no su culto. La preeminencia de la mirada. Ya en fuga, entonces constante y sin bordes -en la Distancia Zero misma-, está su gran proyecto, por ahí va. Las claves, una a una y en progresión, han de irse abriendo: iluminación será, por lo mismo, toda aquella lectura crítica de la escritura límite; la lengua, aquello que hará posible esa relación: primero, como críticidad, y después, en forma de nombre. La hierba, entonces entre la iluminación y su nombre, se abrirá definitivo camino: de felicidad a felicidad, de orden profano de lo profano ${ }^{28}$ a orden profano de lo profano, $\mathrm{y}$, de cada hombre interior a cada sentido otro del sufrimiento. Trazará una natural línea (fugaz en su totalidad) desde la mineralidad escrita, ensayada, a la perfección cultivada del gran diamante -según Nietzsche, el nivel más alto de la materia.

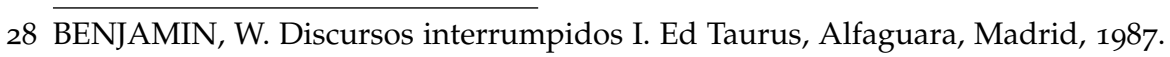




\section{A.27 PRODUCCIÓN \& REGISTRO}

\section{Producción E registro.}

"Los conceptos que la crítica inventa son, en ese sentido, magnetos que detectan los puntos de quiebra de cada sistema, mapas que contribuyen a poner en evidencia en qué sentido las producciones simbólicas valen no por lo que dicen, sino por cuanto desbordan lo que creemos comprender en ellas, lo que nos es dado conocer de ellas." 29

Parece casi una tradición, pero sólo lo parece -a pesar de cierta tendencia del sector artístico a disciplinarse en la sutil dirección de una visible resistencia a la teoría- que todo esfuerzo o tentativa de hacer y dar lugar obvio a la cuestión de la proximidad de la escultura y el lenguaje, como de igual modo a su proximidad con la escritura, no tenga un conveniente (y cierto) espacio de aceptación. En ello parace persistir un problema ontológico fundamental que apunta hacia (y sobre todo) un 'qué hay' en la relación escultura-reflexión que a su vez aguarda, aún en estado larvar y por tanto como porvenir, primero, un sublime 'qué anticipa qué', detenido en el antes condicional, y luego, entonces, un después formalizado. De lo que se trata por tanto es de una problemática de carácter teórico que del mejor modo intentaremos interrumpir, de cara a una argumentación que de fe e igualmente constancia de la ordenación, también aspiración teórica, en el quehacer escultórico de Vicente Ortí, que pensamos que desde la crítica o bien no ha podido decir o bien no se ha sabido decir. Como cuestión inicial dejaremos caer nuestra negación al supuesto -más de un texto referido al artista ofrece un recorrido en esa dirección- de una aproximación descriptiva y acrítica a sus obras (a sus relaciones-objetos, a sus problematizaciones objetualizadas, a sus objetulalizaciones problematizadas). En ese sentido, y hasta ahora, el conjunto de los acercamientos reflexivos a la obra escultórica de Vicente Ortí, condicionados todos por ese acento óntológico no resuelto (decir

29 BREA, J.L. "La crítica en la era del capitalismo cultural electrónico". Agencia Crítica. Edición online: http://www.agenciacritica.net/criticaeck/archivo/2005/11/linea_de_sombra.php. (Consulta: 9 de octubre de 2012) 
sólo de lo que se ve más no de todo lo que hay) y hacia el que antes hemos orientado nuestra atención, hacen resurgir, un sin fin de expresiones relativas a la determinación formal, el tipo de materiales, el proceso de trabajo, etc., o bien, al dominio de la técnica y la singularidad de su expresividad poética, o al diálogo entre el material y la técnica, o a la procesualidad reivindicada, como escribió, entonces con la mejor de las intenciones, Román de la Calle: "Pero ¿es aún necesario acaso insistir en que, dentro de tal proceso, la consideración de los materiales, técnicas y procedimientos no pueden reducirse al papel de simples vehículos, medios o instrumentos, sino que se incardinan por propio derecho en el núcleo fundamental de la concepción y generación global de la obra, disfrutando, por sí mismos, de una capacidad significativa que puede ser tan considerable como la que queda adscribir analíticamente a la propia forma tridimensional de la escultura?" No se trata de aquello albergado en la acción o disposición descriptiva, sino de eso, aquello siempre omitido, que tiene lugar formativo y constitutivo en la producción arte, o bien, obra de arte: de aquello, también, relativo a la concepción de la cosa (en su caso escultórica) y, por extensión, a la idea de mundo que del mismo modo llega a alcanzar la idea de valor, de registro, de percepción y del ver. De lo que se trata es del modo de ver que Vicente apuntala con un cuerpo teorizado en la mismidad del conjunto de relaciones que, en el tiempo, ha ido activando. Por ejemplo hablamos de esas relaciones-objetos devenidas del cruzamiento firme de la fragmentación y la grafía, del saltarse, casi poetizando (dirían), el campo de influencia o zona límite de cada condición fragmento y de cada memoria-grafía, que han llegado a conformar uno de los gestos y propuestas escultóricas (desatendido entonces por la propia comunidad) más saludables y uno de los enfoques, de sensibilidad radicalmente crítica (inevitablemente e irritante para la ortodoxia), en el ámbito y tradición de la escultura valenciana de los 90'. Tras esas acciones-objetos - puesto que en ellas se activaba un cierto acogimiento del gesto (de la gestualidad), del sucederse de una voluntad de fragmentación que a priori distingue entre estratos la dirección puntual de los flujos de significado- había (hay) un cierto efluvio deconstructivo que apunta con literalidad, tal cual su supuesto primero, a "de-construir" el modelo clásico de lo 
que entendemos como cosa-objeto escultórico, a desmantelar visionando (atendiendo) la estructuralidad del modelo de significado del que de algún modo se ha partido (y que una cierta sensibilidad custodia y ampara), que tiene que ver con la idea o concepción de escultura, la idea de objeto escultórico, la idea de significado escultórico y de su papel y función. Esas relaciones-objetos dan fe, al margen de sus evidencias materiales y temáticas, del esfuerzo crítico, asumido en su momento, por liberarse de la servidumbre del discurso heredado como modelo de hacer escultórico, a fin de revelar unas nuevas intuiciones no sólo artísticas, sino sobre todo nuevos modos de hacer y de ver altamente críticos.

Escultura \& registro. Parece que en el sentido de la palabra escultura, aquello que de algún modo da fe de su puesta en circulación o escena, recae sobre la producción o, lo que es lo mismo, sobre su forma de procesamiento y de registro, y no sobre la condición inicial: entonces aquella que habría de marcar decisivamente el carácter necesario -por tanto, de acontecer-conocer-saber- de la cosa a esculturizar, y no, en ese sentido, sobre el carácter necesario, ese 'desde ya condicional', de su también necesario devenir. Sin duda el acontecer escultura, ese 'desde ya' teorizado, ocupa en importancia, en grados de aproximación cognitiva, un mejor lugar en oposición a procesualidad y registro. En esa dirección la cuestión apunta a las ideas escultóricas y no a otro lugar.

La emoción de la escultura no se parece a la escultura en sí, no la representa, del mismo modo que una parte predestinada del proyecto, de su formación inicial, no se parece al dispositivo proyectado que de allí va ha surgir. En el caso de esta exposición, esa disposición instrumental (mesa depósito de herrumbre) hace de algún modo, en tanto que la teatraliza, de emoción de la escultura y así de todo aquello que no lo es pero donde, sin parecerse, sobrevuela un cierto porvenir de la escultura misma, un cierto poder funcionar como ella: una posibilidad o cierto grado de esculturalidad. Esta mesa (o mesas) depósito de herrumbre aguardan como valor (también como posibilidad al fin) de múltiples intensidades, potenciales, umbrales y gradientes escultóricos, todos de carácter orbitativos, que transcurren tal como son: 
como disposiciones intensivas conservadoras de sus antiguas leyes y de su atractivo maquinal, y no, y para nada, como simples acumulaciones.

Oficio/ tradición \& escultura. Justificar la aparición de un nuevo objeto en el ámbito de la escultura parece estar ligado únicamente, todavía, a cuestiones como la tradición o el oficio. Sólo desde la vulgarización, a base de su potencial insensible, el objeto es la medida del valor objeto, es la medida de su artisticidad, cual si ideación, valor y registo constituyera lo mismo. Como ocurre con el arte de forma casi general, también el valor contributivo de la escultura se mide a través del objeto acabado: ya sea un objeto designado (bajo nombramiento) escultura, una combinación de ellas, o lo que el artista decida. Sin embargo, todo aquello relativo a su cognitividad, dígase procesos formativos o temporalidad reflexiva, experiencia de campo, etc, no suele contar como valor aportativo real, como formación experiencial también objetiva e incluso medible. Es costumbre, también de un cierto sector de la crítica, apelando a una infinita sustancialidad, establecer mediciones y baremos en esa dirección: que si el dominio de la piedra, que las entrañas del granito, que sea la piedra desnuda, que la voluntad de la piedra o hasta que la intencionalidad estética del sujeto. En la relación oficio/ tradición \& escultura es entendido el término oficio como un condicionante habitual que diluye el juego crítico -a base de una aureada militancia disciplinar- todo aquello concerniente a la mismidad de la proyección escultura que alberga y propulsa las calidades y pieles de su principio de criticidad. Con la obra de Vicente Ortí, como con la de otros muchos artistas, ha ocurrido lo mismo, ha sido absorbida por ese cierto modelo de concebir la crítica que parte, sin más, del objeto sin condición (dado desde ya como 'escultórico') y por tanto tenido y tomado como la medida en sí del (su) hipotético potencial de valor: el objeto sin condición, sin exterioridad condicionante, brotado del ser insólido y absoluto llamado escultor. En ese conjunto de relaciones-objetos (de fragmentos-memorias-grafías), que tanto nos interesa, subyace la antitésis misma, la potencia de criticar que opone de partida todo su desparpajo a las visiones que para clasificar lo hacen desde el absoluto del objeto, desde el objeto sin condición, y en ese sentido, sin incipit. En ese conjunto hubo (hay) una fuerza de criticar y de oponerse -una fuerza 
de deconstrucción y por tanto de rebeldía-, que en su momento no fue tenida en cuenta, y que nosotros, a través de este esfuerzo de escritura y de crítica hemos pretendido repensar. 


\section{FILMAR LOS MODOS DE LA CRÍTICA}

"Así, por ejemplo, ¿quién traducirá -en francés o en alemán, o en cualquier otra lengua- las tres retículas semánticas de "rodar» en nuestro título: «rodar las palabras»? "Rodar» acumula aquí tres significados en el mismo capital, con todos los valores de cambio o de uso que ustedes quieran, con todas las plusvalías que puedan imaginarse: a. el sentido codificado de la técnica cinematográfica (no se dice «rodar un filme» en alemán ni en inglés); señalémoslo de pasada, en el código impuesto por cierta época de la máquina cinematográfica, el uso de este verbo, «rodar», puede ser transitivo (rodar una escena, rodar las palabras) o intransitivo («silencio, se rueda»); $b$. los sentidos cinéticos de movimientos tales como «rodear, evitar, sobrepasar, exceder, transgredir», pero también, desde el momento en que se trata de rodear, «rodar en torno a», $y$ «a lo largo de», lo que casi quiere decir lo contrario: insistencia obsesiva, fascinación, retorno a un centro inaccesible, tematización incansable, etc.; ahora bien, nutre el texto o el tejido de nuestro filme, su película misma se asemeja al tamiz, o sea a la criba de tal insistencia; c. el sentido más estilístico de «ajustar»-refinar, dar la buena forma, etc.- cuándo se trata de «rodar las palabras» bien, de hablar bien, de encontrar la expresión adecuada.

Ahora bien, estos sentidos no están sólo yuxtapuestos, sino que se capitalizan en el abismo de una especulación virtual: a puede rodear a $c$ mientras retorna a $b$, y c puede utilizar $a b$ «hablando» $o$ «haciendo hablar» $a$ a, etc. Esto es lo que haríamos, verdad, en el filme y al borde del filme..."1

1 DERRIDA, JACQUES/ FATHY SAFAA. Rodar las palabras. Al borde de un filme. Ed. Arena Libros D.L. Madrid, 2004. Pág. 17 


\section{¿Qué nos mueve a realizar estos dossier/entrevista?}

Elaborar a partir de las entrevistas un archivo videográfico que muestre el estado de la cuestión del sistema del arte en relación a las transformaciones de las áreas productivas, la proyección/soporte institucional, la influencia o percepción social de nuestro ámbito de trabajo; el objetivo es disponer en red -públicamente en nonsite ${ }^{2}-$ un cúmulo de documentación que aporte un mayor conocimiento de la realidad del sistema del arte español contada en primera persona y desde los distintos sectores que configuran la práctica cultural (artistas, críticos, galeristas, comisarios, directores de centros, museos, docentes, periodistas, público, etc.).

Las entrevistas fueron propuestas a partir del siguiente guión:

$\triangleright$ Se formula una pregunta general a todos los sectores que, a modo de

2 http:www.nonsite.es

NONSITE, es una plataforma online de producción, difusión y distribución de las prácticas artísticas contemporáneas; como estructura cultural observa las transformaciones que las nuevas tecnologías de la imagen y los nuevos medios están produciendo en los espacios habituales destinados a la presentación de propuestas artísticas (museos, galerías, centros culturales,...) Utilizando el vídeo online como medio, NONSITE se propone como objetivo poner a disposición de la comunidad artística una serie de servicios dirigidos a la promoción y mejor conocimiento e información de la producción cultural. NONsITE presta servicios de producción y difusión a instituciones, artistas, galerías y profesionales del arte, si deseas obtener más información utilice el formulario de Contacto. INFO Convocatoria ministerio: En 2003 apareció NONSITE (ISSBN: 1697-6657), una publicación dirigida por Bárbaro Miyares, dedicada a reflexionar sobre la práctica artística entendida desde un punto de vista transdisciplinario -sin horizontes garantizados; ensayos, entrevistas, reseñas y críticas sobre exposiciones, cine, arquitectura o música, en torno a la producción artística y visual contemporánea a partir de textos de José Luis Brea, Luis Camnitzer, Miguel Molina, Paula Álvarez, Rafael Castro, Solal, etc. En mayo de 2007 se constituye NONSITE, Sociedad Civil con el objetivo de ofertar servicios de edición, producción y postproducción de eventos y exposiciones, su objetivo central es la búsqueda de estrategias para mejorar la difusión de la práctica artística contemporánea desarrollada en instituciones y galerías de arte a través de la plataforma de vídeo en línea: www.nonsite.es. Desde 2006, nonsite, s.c. ha realizado la difusión y promoción de los siguientes eventos y exposiciones: - Seminario Nanoconexiones en la frontera de lo invisible: relaciones entre el arte, la ciencia y la sociedad a través de la Nanotecnología. 2008 - Exposición Digital Media Valencia, Universitat de València. 2008 - I Encuentro Internacional Pensar la movilidad en dos direcciones: Estéticas Migratorias, CENDEAC, Murcia. 2007 - Presentación del Libro blanco de la interrelación entre Arte, Ciencia y Tecnología en el Estado español Madrid, 2007 - Curso Los Estudios Visuales: geopolíticas de la imagen el la sociedad del conocimiento. Madrid 2006. - Exposición Laboratorio de Luz. Especulaciones a un tiempo, Centro Párraga, Murcia 2006 - $1^{\circ}$ Bienal de Arquitectura, Arte y Paisaje de Canarias, 2006. También ha participado en Proyectos de intervención artística: - "Experiencia de relacionar: luz / señal / iluminación", $1^{\circ}$ Bienal de Arquitectura, Arte y Paisaje de Canarias, Castillo Negro, Tenerife, 2006. - "Experiencia de relacionar: ciudadano_lugar", Intervencions Plàstiques a Xàbia (Camins Oberts XIV), 2006 "Experiencia de relacionar: autorretrato/contexto", 9 a Bienal Martínez Guerricabeitia, Museo de la Ciudad de Valencia, 2008 
introducción, trate sobre el contexto actual y las políticas culturales, al estilo de:

- En el contexto español ¿Consideras que se están llevando a cabo políticas culturales adecuadas? ¿Destacarías alguna iniciativa? ¿Son publicas o privadas? ¿Desde que instituciones?

- En relación al ámbito de las humanidades -donde se inscribe nuestro campo disciplinar-, la práctica cultural es un territorio que traspasa límites, o bien se disuelve o bien multiplican en otras tareas (p.e. el artista como antropólogo, el crítico comisario, el director de museo como teórico o/y comisario) ¿Consideras que esta hibridación fomenta una percepción de la práctica cultural como territorio "confuso", poco profesional, donde todo vale? ¿Apoyarías la creación de una Ley del Arte? ¿Crees que es necesaria?

El listado inicial para la confección de nuestro primer dossier de crítica solicitaba la colaboración de los siguientes personalidades:

$\triangleright$ Román de la Calle, Ricardo Forriols, Elena Vozmediano, Nilo Casares, Domingo Mestre, José Luis Clemente, Rocío de la Villa, Álvaro de los Ángeles, Miguel Ángel Hernández-Navarro, Mieke Bal, Juan Luis Moraza, Juan Bautista Peiró, Juan Vicente Aliaga, David Pérez, Daniel García Andújar, Rosa Olivares, José Luis Brea, Manuel Borja-Villel, José Miguel G. Cortés, Fernando Castro, Pau Rausell, Martí Peran. 
B.I ROMÁN DE LA CALLE

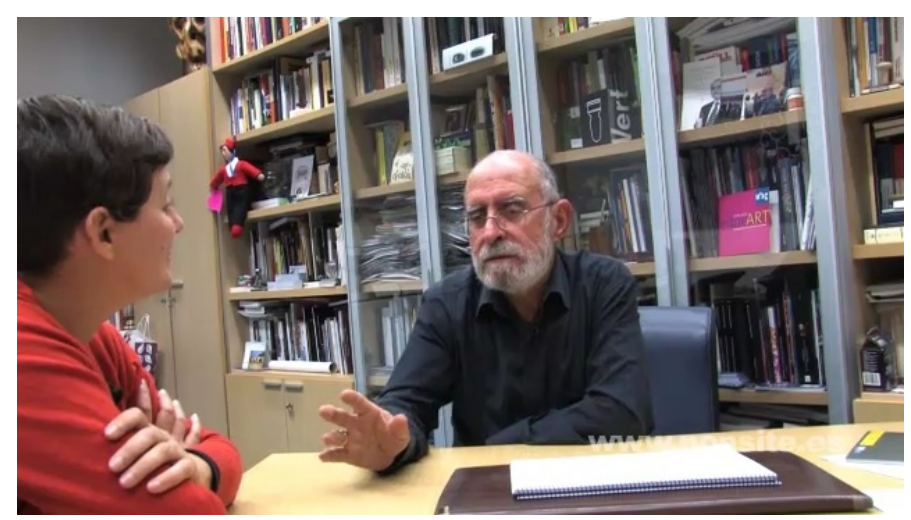

Figura 41: Román de la Calle - Crítico de arte.

Director del Museu Valencià de la Il.lustració i de la Modernitat (Muvim), Catedrático de la Universitat de Valencia y crítico de arte. $\triangleright$ http://tinyurl.com/blxst42 


\section{B.2 RICARDO FORRIOLS}

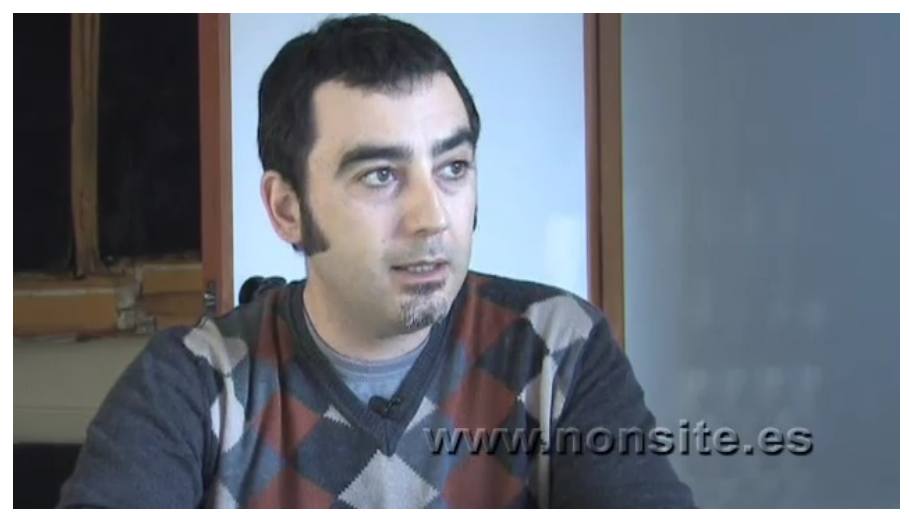

Figura 42: Ricardo Forriols - crítico de arte

Crítico de arte y profesor del Departamento de Comunicación Audiovisual, Documentación e Historia del Arte, Universidad Politécnica de Valencia.

$\triangleright$ http://tinyurl.com/bbtn27c 


\section{B.3 ELENA VOZMEDIANO}

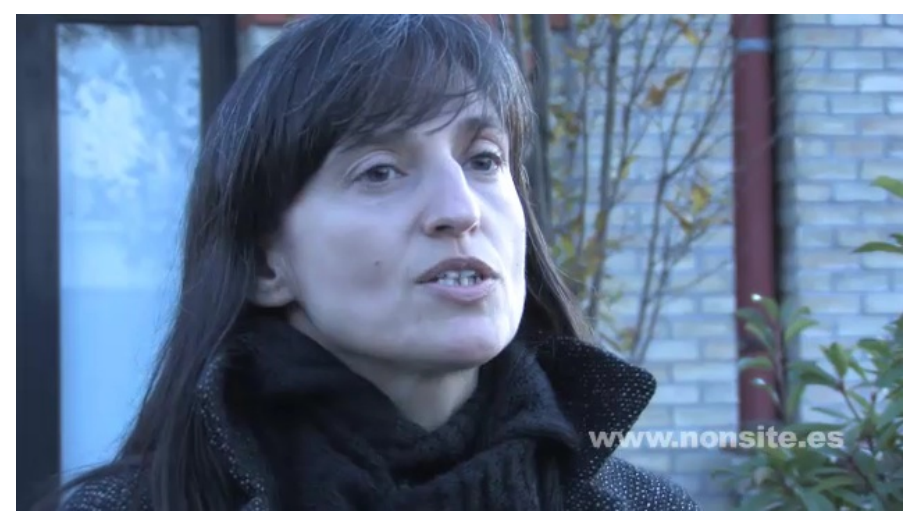

Figura 43: Elena Vozmediano - Crítica de arte

Crítica de arte, El Cultural (El Mundo). Licenciada en Historia del Arte por la Universidad Complutense, colabora puntualmente en publicaciones como Revista de Libros, Revista de Occidente y Arquitectura Viva. Presidenta del Instituto de Arte Contemporáneo (IAC): www.iac.org.es + info: http://www.elena.vozmediano.info $\triangleright$ http:/ / tinyurl.com/az3vfvj 


\section{B.4 NILO CASARES}

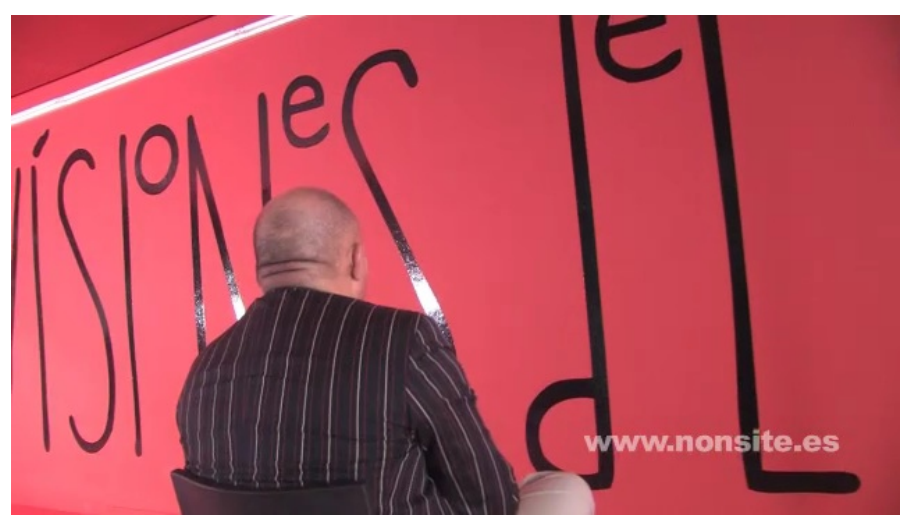

Figura 44: Nilo Casares - crítico de arte

Escritor, comisario y crítico de arte. + info: www.comisario.net $\triangleright$ http://tinyurl.com/awq8rae 


\section{B.5 DOMINGO MESTRE}

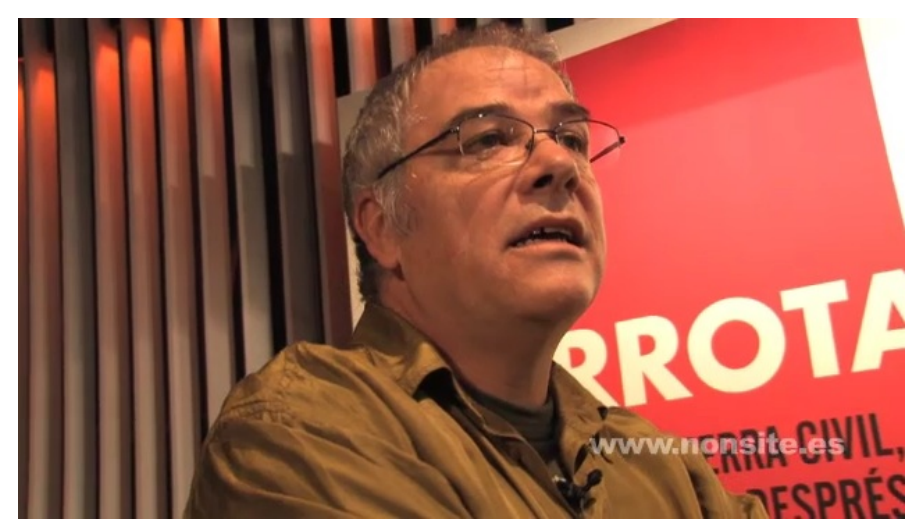

Figura 45: Domingo Mestre - artista y escritor

Artista visual y escritor especializado en arte y cultura. Miembro del equipo editorial y de administración de e-valencia.org. Profesor del Máster La Fábrica en Ingeniería Cultural de la Universidad Europea de Madrid. La versión texto ha sido publicada en e-valencia.org $\triangleright$ http:/ / tinyurl.com/aqhqnts 


\section{B.6 JOSÉ LUIS CLEMENTE}

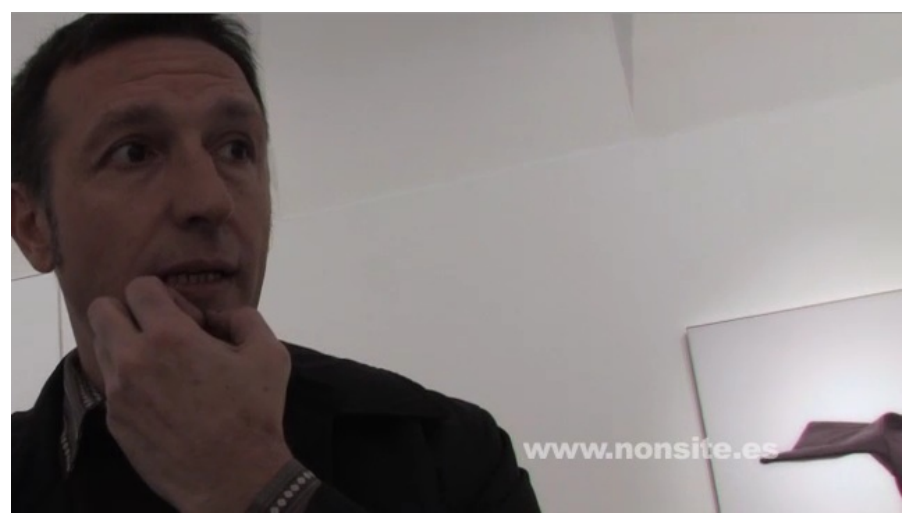

Figura 46: José Luis Clemente - crítico de arte

Crítico, comisario y profesor del Dpto. Com. Audiovisual, Documentación e Historia del Arte. UPV.

$\triangleright$ http:/ / tinyurl.com/ag8mgy4 
B.7 ROCÍO DE LA VILLA

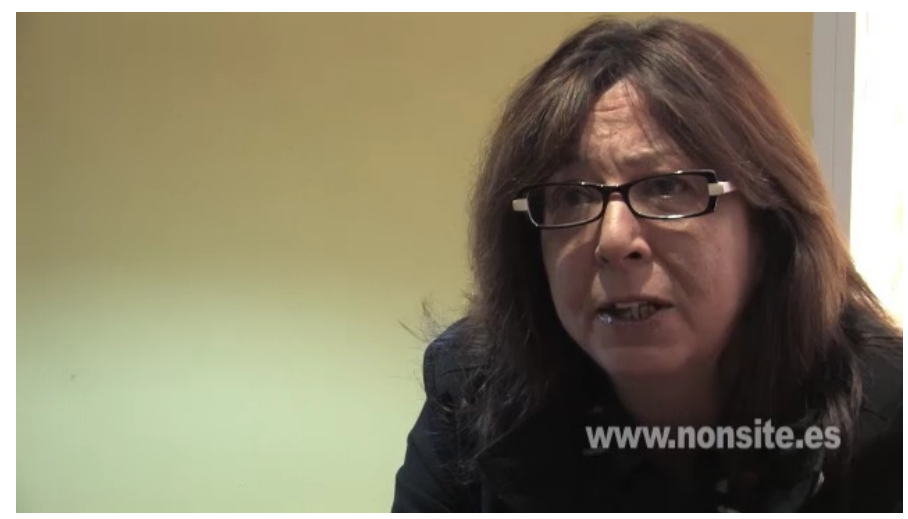

Figura 47: Rocío de la Villa - crítica de arte

Profesora de Estética y Teoría de las Artes, Universidad Autónoma de Madrid. Como crítica de arte, colabora habitualmente en Cultura/s (LA VANGUARDIA), El Cultural (EL MUNDO) y otras revistas especializadas. Presidenta de MAV (Mujeres en Artes Visuales) http:/ / www.mav.org.es

$\triangleright$ http://tinyurl.com/aq3coum 


\section{B.8 ÁlVARO DE LOS ÁNGELES}

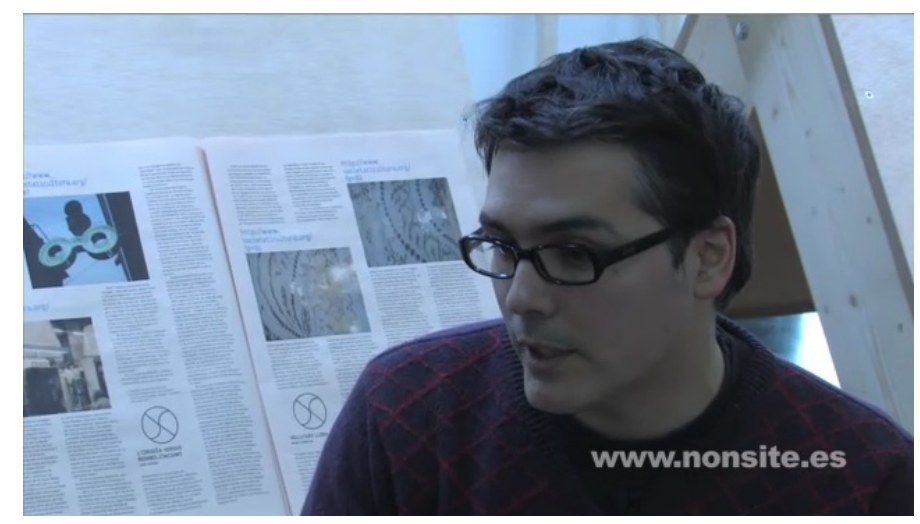

Figura 48: Álvaro de los Ángeles - crítico de arte

Crítico de arte, comisario y profesor de la Universidad Politécnica de Valencia. http://www.alvarodelosangeles.org

$\triangleright$ http://tinyurl.com/ae8bnch 
B.9 Miguel ÁNGEL HeRnÁNDEZ-NAVARRo

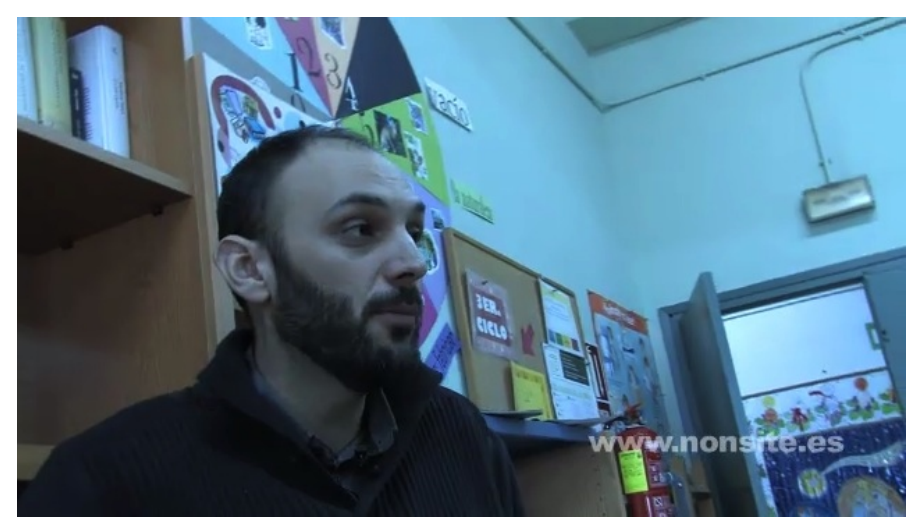

Figura 49: Miguel Ángel Hernández-Navarro - Escritor y crítico de arte

Escritor y crítico de arte. Profesor de Historia del Arte (Universidad de Murcia). Autor, entre otras cosas, de "Infraleve: lo que queda en el espejo cuando dejas de mirarte" (2004), "La so(m)bra de lo Real: el arte como vomitorio" (2006) y "El archivo escotómico de la modernidad: pequeños pasos para una teoría de la visión" (2007) + info: http://nohalugar.blogspot.com

$\triangleright$ http:/ / tinyurl.com/akb252d 


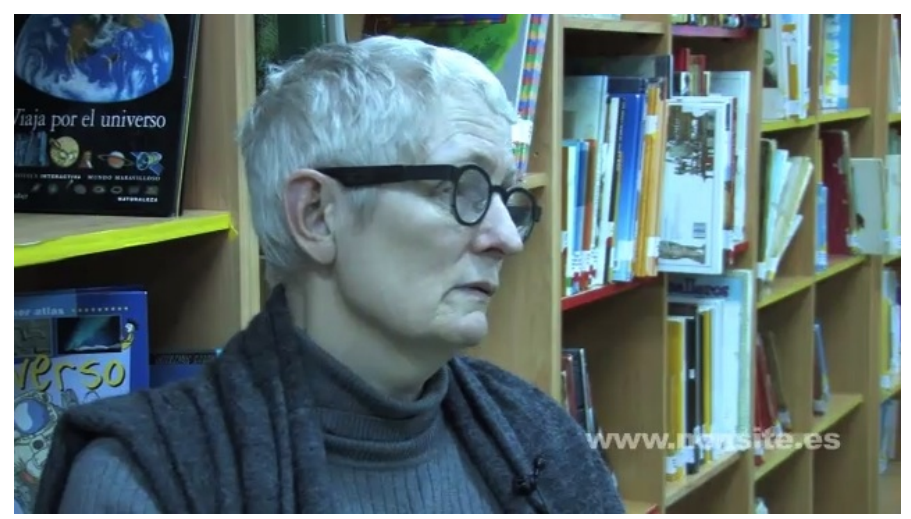

Figura 50: Mieke Bal - teórica y crítica cultural

Entrevistamos a Mieke Bal (teórica y crítica cultural, profesora del Royal Netherlands Academy of Arts and Sciences (KNAW) y titular de la Amsterdam School for Cultural Analysis (ASCA), University of Amsterdam) durante el rodaje de su último "cinema suitcase" dirigido junto a Michelle Williams; se trata de un film basado en la novela "Mère Folle!" de la psicoanalista francesa Françoise Davoine. + info del proyecto: http:/ /www.crazymothermovie.com + info de Mieke Bal: http:/ / www.miekebal.org

$\triangleright$ http://tinyurl.com/apzya5q 
B.I1 JUAN LUIS MORAZA

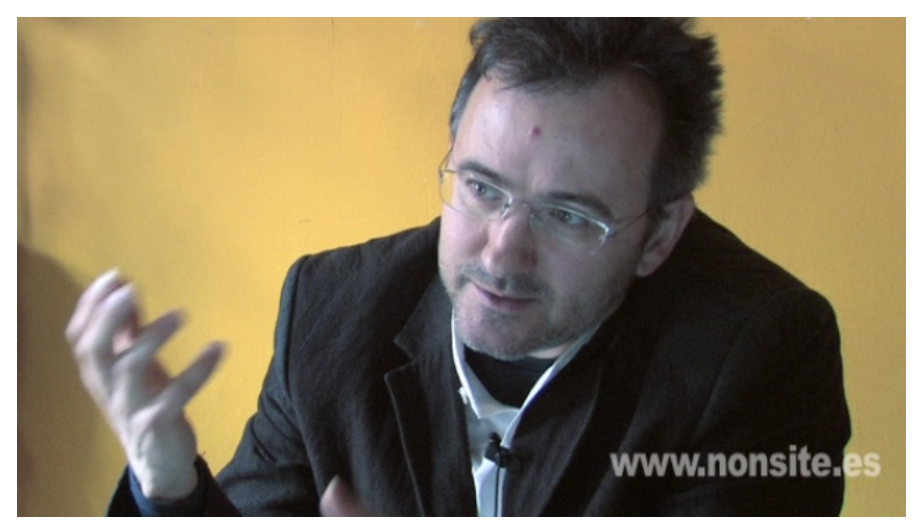

Figura 51: Juan Luis Moraza - artista y profesor

Artista y Profesor titular del Departamento de Escultura de la Facultad de Bellas Artes de la Universidad de Vigo. Ha organizado y participado en diferentes seminarios, cursos y jornadas sobre creatividad y producción artística en la nueva sociedad del conocimiento.

$\triangleright$ http://tinyurl.com/bknlgra 
B.12 JUAN BAUTISTA PEIRÓ

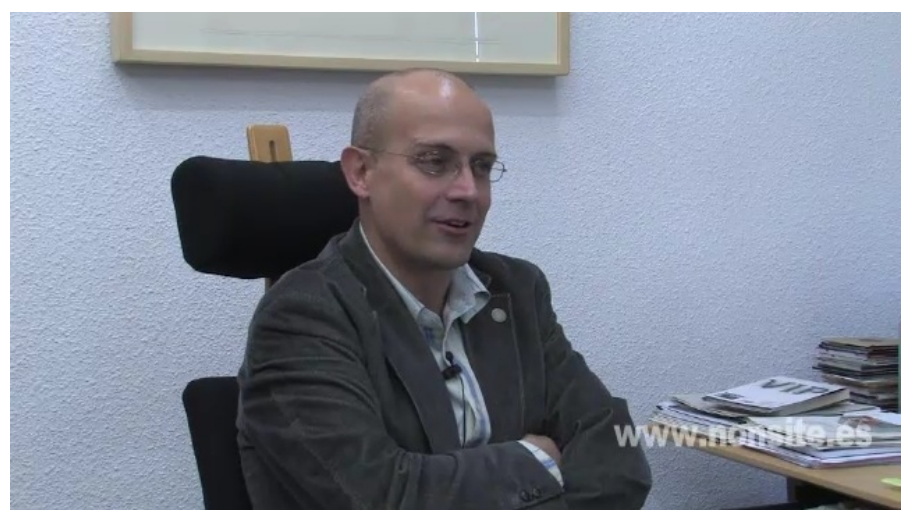

Figura 52: Juan Bautista Peiró - Crítico de arte

Crítico de arte y profesor Departamento. Pintura y Vicerrector de Cultura, Comunicación e Imagen Institucional. UPV.

$\triangleright$ http://tinyurl.com/apgwytl 


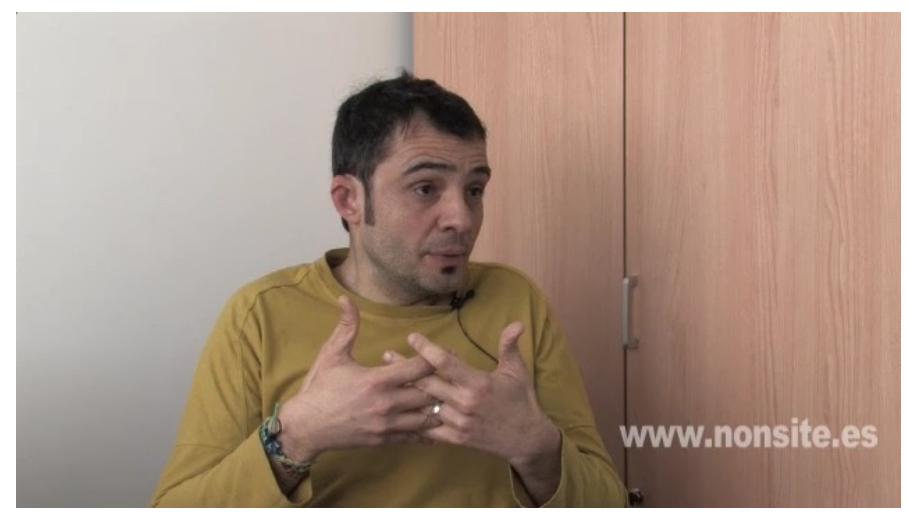

Figura 53: Juan Vicente Aliaga - crítico y comisario

Profesor de la Facultad de Bellas Artes de la Universidad Politécnica de Valencia y corresponsal de la revista Artforum en España. Recientemente ha publicado Orden fálico. Androcentrismo y violencia de género en las prácticas artísticas del siglo XX (2007). Ha comisariado diversas exposiciones entre las que destacan: Formas del abismo. El cuerpo y su representación extrema en Francia 1930-1960 (Koldo Mitxelena 1994), Claude Cahunn (IVAM 2001), Micropolíticas. Arte y cotidianidad (EACC 2002), y Pepe Espaliú (MNCARS 2003).

$\triangleright$ http:/ / tinyurl.com/ac4k98x 
B.14 DAVID PÉREZ

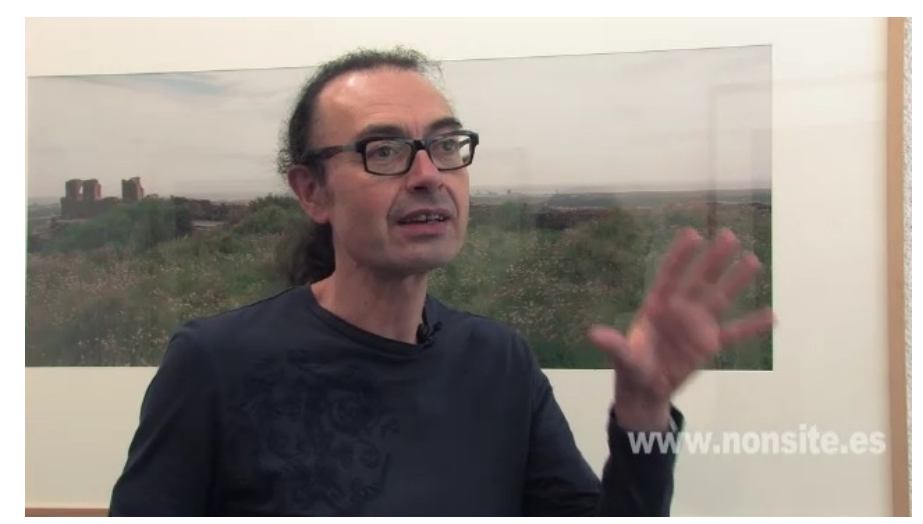

Figura 54: David Pérez - Crítico de arte

David Pérez, es crítico e historiador del arte. Profesor titular de Teoría de la Pintura Contemporánea en la Universidad Politécnica de Valencia. Galardonado con el premio Espais a la Crítica de Arte en las ediciones de 1991 y 1996. En 1999 fue responsable del Pabellón Español de la 48 Bienal de Venecia. Entre sus libros destacan: La mirada contra la Historia (1995), Femenino, Plural: Reflexiones desde la diversidad (1996), Del arte impuro. Entre lo público y lo privado (1997) y Malas artes. Experiencia estética y legitimación institucional (2003).

$\triangleright$ http://tinyurl.com/az2f837 
B.15 DANIEL GARCíA ANDÚJAR

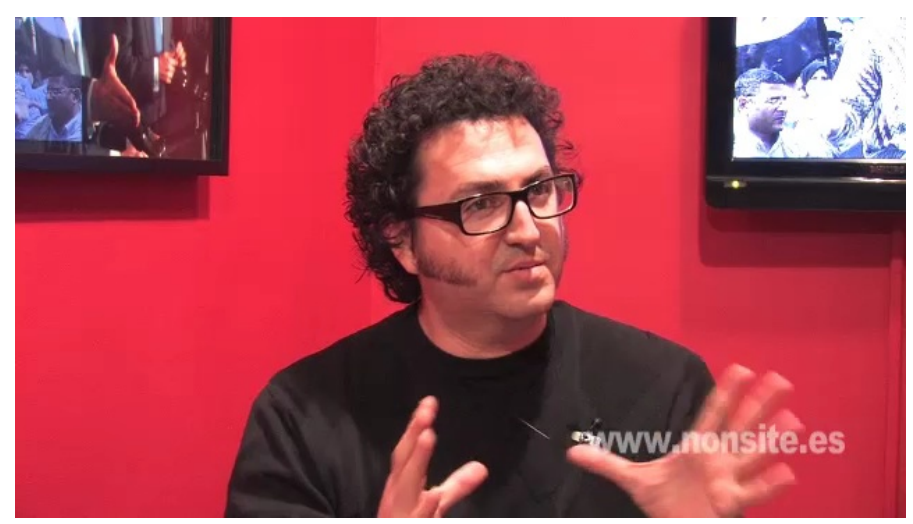

Figura 55: Daniel García Andújar - artista visual y activista

Artista visual de los medios, activista y teórico del arte español. Vicepresidente primero de la AAVC. + info: http://www.danielandujar.org

$\triangleright$ http://tinyurl.com/b9u435y 


\section{B.16 ROSA OLIVARES}

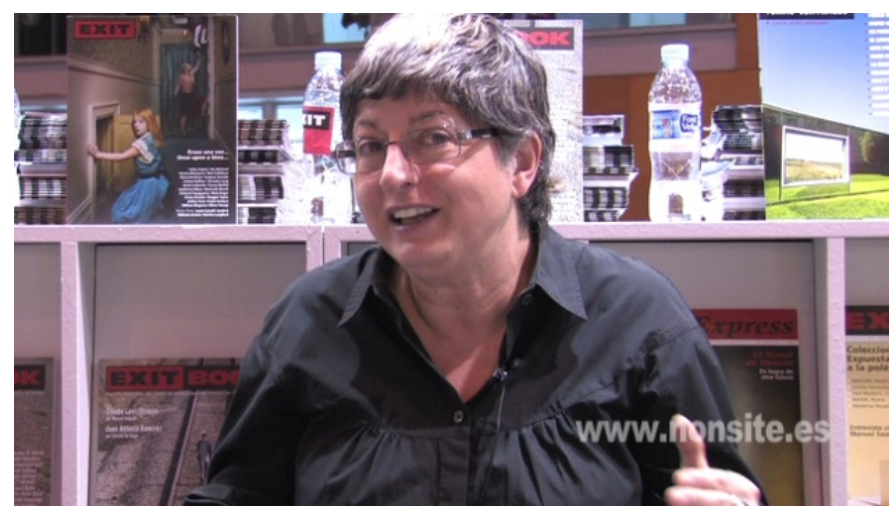

Figura 56: Rosa Olivares - crítica de arte y directora de EXIT

Directora de la revista EXIT, Imagen \& Cultura. Editora, escritora, periodista y crítica de arte, ha colaborado en diversos medios desde 1975, entre los que destacan: RNE, Arts Magazine, Paris Photo, Aena Arte, La Razón, ABC Cultural, El Cultural de El Mundo.

$\triangleright$ http://tinyurl.com/bzpbftz 
B.17 JOSÉ LUIS BREA

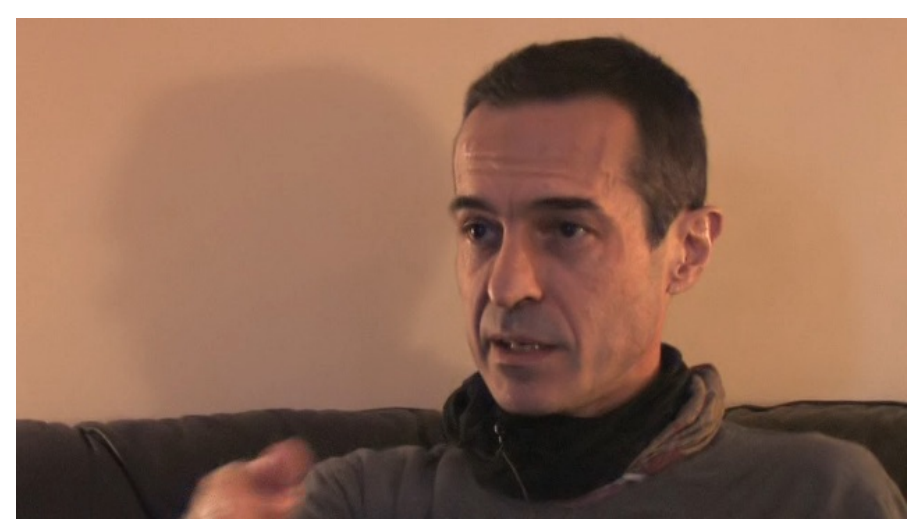

Figura 57: José Luis Brea - crítico de arte y comisario

Profesor Titular de Estética y Teoría del Arte Contemporáneo de la Universidad Carlos III de Madrid. Es director de las revistas Estudios Visuales y ::salonKritik::. Crítico de arte independiente, colabora con diversas revistas nacionales e internacionales. Es director de las colección Estudios Visuales de la editorial AKAL. Entre sus libros más recientes destacan: Las 3 eras de la imagen. Imagen-materia, film, e-image, ed. AKAL, Madrid, 2010; cultura_RAM. mutaciones de la cultura en la era de su distribución electrónica, PREMIO DE ENSAYO EUSEBI COLOMER DE LA FUNDACIÓN EPSON, Gedisa, Barcelona, 2007. Noli me legere. El enfoque retórico y el primado de la alegoría en el arte contemporáneo, CENDEAC, Murcia, 2007. Estudios Visuales. La epistemología de la visualidad en la era de la globalización, (ed.) AKAL, Madrid, 2005 + info: http:/ /www.joseluisbrea.net/

$\triangleright$ http://tinyurl.com/b7ov8b3 
B.18 MANUEL BORJA-VILLEL

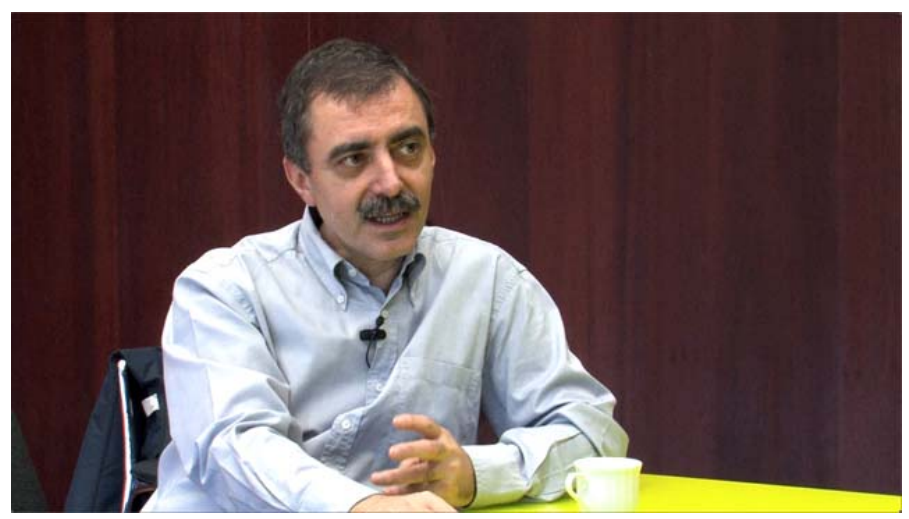

Figura 58: Manuel Borja-Villel / Director MNCARS

Manuel Borja-Villel. Director del Museo Reina Sofía de Madrid (MNCARS) desde enero de 2008. Ha dirigido también el museo de la Fundación Antoni Tàpies de Barcelona y el Museo de Arte Contemporáneo de Barcelona (MACBA).

$\triangleright$ http:/ / tinyurl.com/agza27w 
B.19 JOSÉ MIGUEL G. CORTÉS

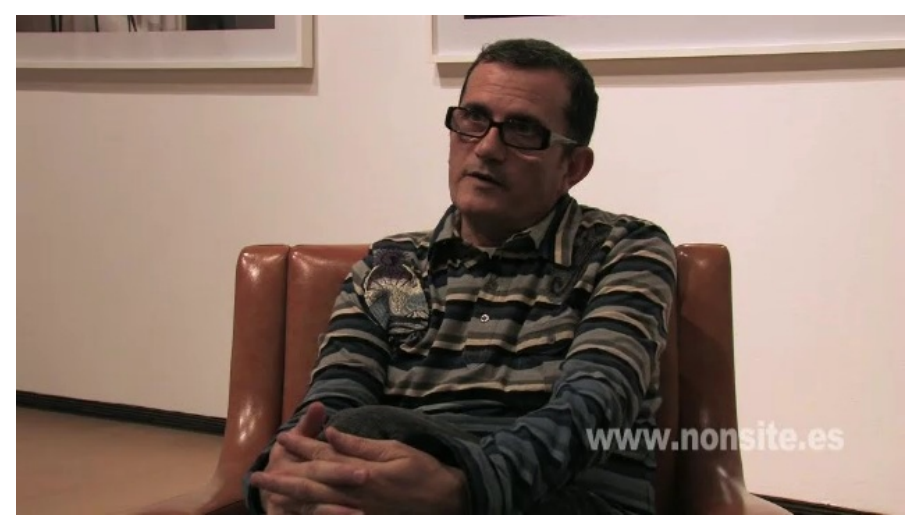

Figura 59: José Miguel G. Cortés /Comisario y escritor

Doctor en Estética y profesor titular de Teoría del Arte de la Facultad de Bellas Artes de Valencia. Ha sido director del Espai d'Art Contemporani de Castelló desde abril de 1998 hasta octubre del 2003. Ha escrito diferentes libros entre ellos destaca: Espacios Diferenciales. Experiencias Urbanas entre el arte y la arquitectura, (2008).

$\triangleright$ http:/ / tinyurl.com/atfuhn3 


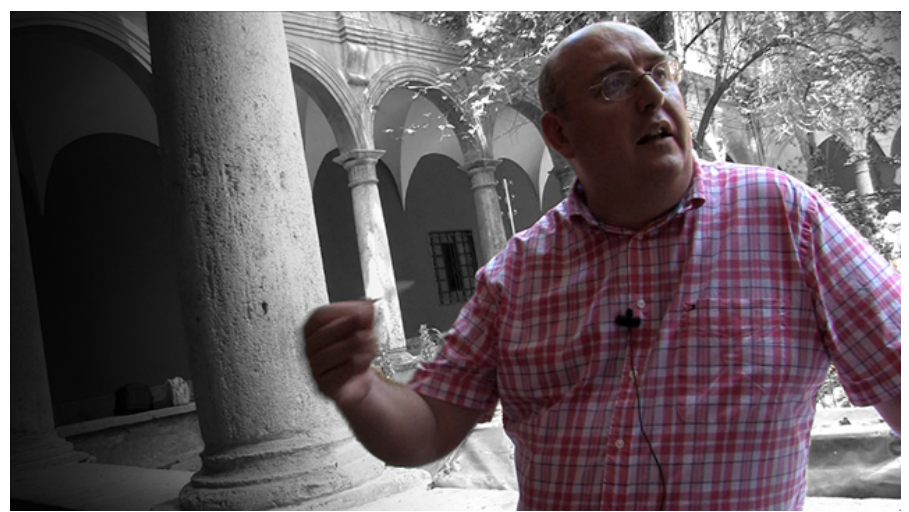

Figura 6o: Fernando Castro - Crítico y comisario

Profesor de estética y Teoría de las Artes de la Universidad Autónoma de Madrid. Comisario de exposiciones. Crítico de Arte de ABCD las Artes y las Letras. Colaborador habitual de Revista de Occidente, Contrastes, Exit Book, Descubrir el Arte, entre otras publicaciones periódicas. Ha escrito, entre otros, los siguientes libros: Escaramuzas. El arte en el tiempo de la demolición; Fasten Seat Belt. Cuaderno de campo de un crítico de arte; Matadlos a todos, dios reconocerá a los suyos; El inquietante lugar del hombre. Sobre Juan Muñoz; Fight Club. Consideraciones en torno al arte contemporáneo; y Mensajes sin códigos. [Notas sobre la fotografía].

$\triangleright$ http://tinyurl.com/bjrynug 
B.21 PAU RAUSELL

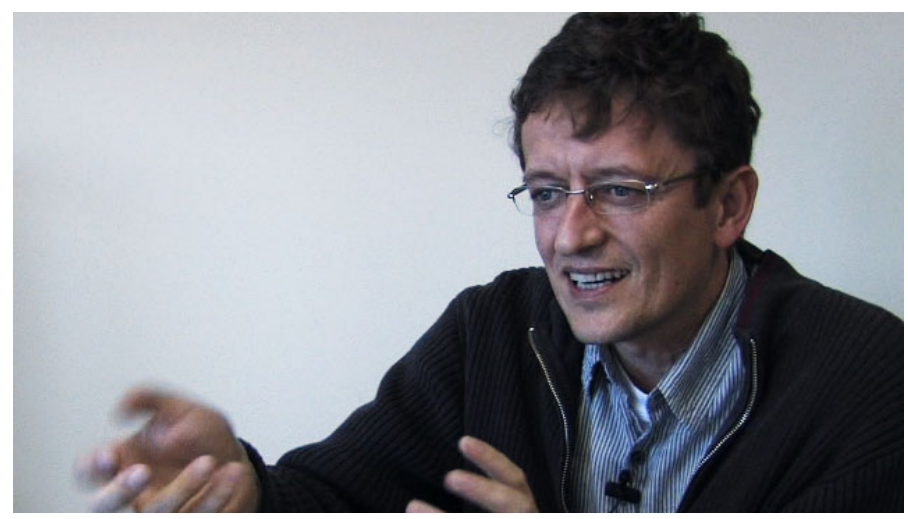

Figura 61: Pau Rausell - Investigador Economía Aplicada a la Cultura

Economista. Profesor titular del Departamento de Economía Aplicada de la Universitat de Valencia. Director del Área de Investigación en Economía Aplicada a la Cultura. Participa en proyectos de investigación europeos (Sostenuto), e iberoamericanos (Observatorio Iberoamericano de Cultura, Proyecto SIEDECC) + info: http://www.uv.es/ econcult/ $\triangleright$ http://tinyurl.com/akfoxpy 
B.22 MARTÍ PERAN

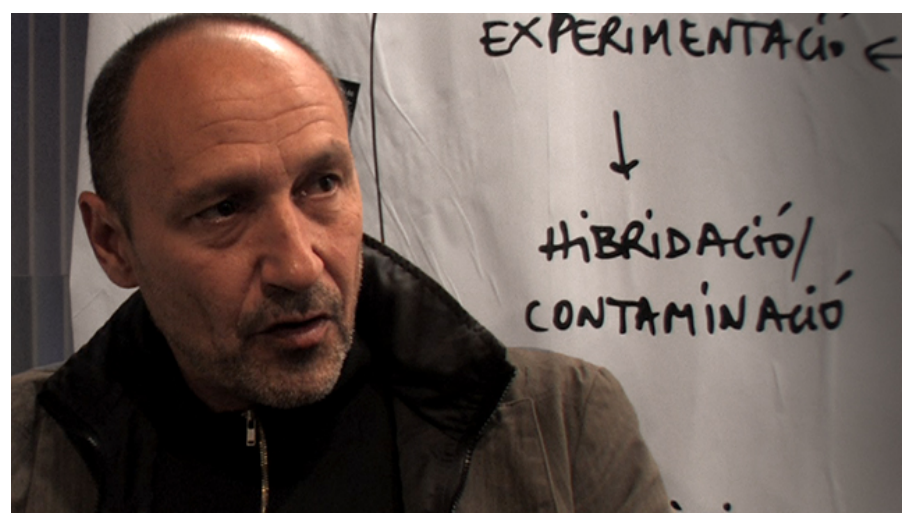

Figura 62: Martí Peran - Crítico y comisario

Profesor Titular de Teoría del Arte de la Universidad de Barcelona. Ha participado en numerosos libros y catálogos de arte contemporáneo, destacamos entre sus últimos proyectos "Post-it city. Occasional Cities" (CCCB,Barcelona,20o8; MAC Santiago de Chile, Centro Cultural Sao Paulo, 2009); "After Architecture" (Arts Santa Mònica. Barcelona,2009). Colabora habitualmente en "Exit Express" y "Artforum International". + info: http:/ / www.martiperan.net

$\triangleright$ http://tinyurl.com/ab44rof 



\section{BIBLIOGRAFÍA}

[1] » blog archive » juan luis moraza: sobre la investigación artística. http://www.victordelrio.es/blog_docente/?p=357. URL http:// www. victordelrio.es/blog_docente/?p=357.

[2] Cuadernos de administración (universidad del valle) - some quiestions for industrial engineering education in colombia. http://www.scielo.org.co/scielo.php?pid=So12046452012000200008\&script=sci_arttext, . URL http: //www. scielo. org.co/scielo. php?pid=S0120-46452012000200008\&script=sci arttext.

[3] CulturaenlaRed. http://tinyurl.com/okrxzda, . URL http:// tinyurl.com/okrxzda. Nueva revista electrónica del Ministerio que ace con el objetivo de dar a conocer los proyectos de difusión cultural del Departamento y sus instituciones, desarrollados con el apoyo de las nuevas tecnologías de gestión de la información.

[4] DDOOSS, joseph beuys. http://tinyurl.com/qzaxzvp. URL http: //tinyurl.com/q2axzvp.

[5] Estafeta: THEODOR w. ADORNO - teoría estética. http:/ / estafeta-gabrielpulecio.blogspot.com.es/2010/o3/theodorw-adorno-teoria-estetica.html,

. URL http://estafeta-gabrielpulecio.blogspot.com.es/2010/ 03/theodor-w-adorno-teoria-estetica.html.

[6] Estafeta:

ROLAND

BARTHES - retórica de la imagen. http://tinyurl.com/pt2wrqj, . URL http://tinyurl. com/pt2wrqj.

[7] Estética

teoría del arte: agosto 2011. http://tinyurl.com/q6mkb92, . URL http://tinyurl. com/q6mkb92. 
[8] fin(es)

del

arte:

Joseph

kosuth. http://artecontempo.blogspot.com.es/2005/og/josephkosuth.html. URL http://artecontempo.blogspot.com.es/2005/ 09/joseph-kosuth.html.

[9] Gustavo

bueno, el mapa como institución de lo imposible, el catoblepas 126:2, 2012. http://www.nodulo.org/ec/2012/n126po2.htm. URL http://www. nodulo.org/ec/2012/n126p02.htm.

[10] Haciendo el giro irit rogoff. http://tinyurl.com/nn53vp2. URL http://tinyurl. com/nn53vp2.

[11] Modelos $\mathrm{y}$ tendencias de la formación docente. http://www.oei.es/cayetano.htm. URL http://www. oei.es/cayetano.htm.

[12] Philosophica: Enciclopedia filosófica on line - voz: Gilles deleuze. voz de archivo 2012. http://tinyurl.com/nfujf8z. URL http: //tinyurl.com/nfujf8z.

[13] Arte y ontología. crítica de los saberes establecidos I maría antonia gonzález valerio academia.edu. http://www.academia.edu/2568387/arte y ontologia, . URL http: //Www. academia.edu/2568387/arteyontologia.

[14] Art school propositions. http://es.scribd.com/doc/47962381/ArtSchool-Propositions, URL http: //es.scribd.com/doc/47962381/Art-School-Propositions.

[15] [odiseo revista de pedagogía - ISSN 1870-1477] - barraza. el papel de

las universidades. http://www.odiseo.com.mx/2005/o7/barrazasaberypoder.htm. URL http://www.odiseo.com.mx/2005/07/ barraza-saberypoder.htm.

[16] Públicos y contrapúblicos. Univ. Autònoma de Barcelona/MACBA, 2008. ISBN 9788489771246. 
[17] NY, May 2009. URL http://nohalugar.blogspot.com/2009/05/ ny. html.

[18] Individuo, April 2013. URL https://es.wikipedia.org/w/ index. php?title=Individuo\&oldid=66090767. Page Version ID: 66090767 .

[19] Marí Acaso López-Bosch. La educación artística no son manualidades: nuevas prácticas en la enseñanza de las artes y la cultura visual. Los Libros de la Catarata, February 2009. ISBN 978-84-8319-413-3.

[20] Theodor W. Adorno. Sobre Walter Benjamin. Ediciones Cátedra, Madrid, April 1995. ISBN 9788437613338.

[21] Ernesto Chinchilla Aguilar. Versiones de historia en tres clásicos de la lengua española. Universidad de San Carlos de Guatemala, 1960.

[22] LA SOCIÉTÉ ANONYME. Redefinición de las prácticas artísticas S.21 (lsa47).

[23] Paul Ardenne. Un arte contextual: creación artística en medio urbano, en situación, de intervención, de participación, volume 2. CENDEAC, Murcia, 2006.

[24] Chris Argyris and Agustín Gil Lasierra. El individuo dentro de la organización. 1979. URL http://dialnet.unirioja.es/servlet/ libro? codigo $=245247$.

[25] Rudolf Arnheim. Consideraciones sobre la educación artística. 1993.

[26] Jordi Claramonte Arrufat. Edades del monstruo, August 2011. URL http://jordiclaramonte.blogspot.com.es/2011_08_ 01_archive.html.

[27] VARIOS AUTORES. Didáctica de las artes y la cultura visual. Ediciones AKAL, Madrid, 2011. ISBN 9788446031147.

[28] Mieke Bal. Anacronismos. 
[29] Mieke Bal. Conceptos viajeros en las humanidades. Una guía de viaje. CENDEAC, Murcia, 2009.

[30] Mieke Bal. Trabajar con conceptos: el anacronismo como lupa. 2011.

[31] Zygmunt Bauman. Los retos de la educación en la modernidad líquida. Gedisa Barcelona, 2007.

[32] Han Belting. Antropología de la imagen. Katz Editores, Madrid, 2007.

[33] W. Benjamin. la dialectica en suspenso. Singular plural. Lom Ediciones, 2009. ISBN 9789560000699. URL http://books. google. es/books?id=8IQYFxxcWigC.

[34] Walter Benjamin. Discursos interrumpidos I. Madrid, Taurus, 1990.

[35] Walter Benjamin. La obra de arte en la época de su reproducibilidad técnica. Archivos de la fotografía, 3(2):15-43, 1997.

[36] Walter Benjamin. Libro de los pasajes. Ediciones AKAL, Madrid, 2005 .

[37] Walter Benjamin. El narrador. Ediciones Metales Pesados, Chile, 2011.

[38] Henri Bergson. Memoria y Vida: textos escogidos por Gilles Deleuze. Alianza Editorial, Madrid, 2004.

[39] José Luis Brea. Las auras frías. Anagrama, Barcelona, 1991.

[40] José Luis Brea. Nuevas estrategias alegóricas. Tecnos, Madrid, 1991.

[41] José Luis Brea. Idea de la claridad. Arte: proyectos e ideas, 1, 1994.

[42] José Luis Brea. Un ruido secreto: El arte en la era póstuma de la cultura. Murcia: Editorial Mestizo, 1996., 1996.

[43] José Luis Brea. Transformaciones contemporáneas de la imagen movimiento. Acción Paralela, (5), 1998. 
[44] José Luis Brea. Políticas del arte. Acción Paralela, (4), 1998.

[45] José Luis Brea. La era postmedia: acción comunicativa, prácticas (post) artísticas y dispositivos"neomediales". Salamanca: Centro de arte de Salamanca, 2002.

[46] José Luis Brea. El tercer umbral: estatutos de las prácticas artísticas en la era del capitalismo cultural. CENDEAC, Murcia, 2003.

[47] José Luis Brea. Los estudios visuales: por una epistemología política de la visualidad. Madrid, Akal/Estudios Visuales, 2005.

[48] José Luis Brea. Cultura_RAM: Mutaciones de la cultura en la era de su distribución electrónica. Gedisa Barcelona, 2007.

[49] Susan Buck-Morss. Dialéctica de la mirada: Walter Benjamin y el proyecto de los Pasajes. Visor, Madrid, 1995.

[50] Gustavo Bueno. ¿Qué es un aventurero? prólogo al libro de José Ignacio García Noriega, Hombres de brújula y espada. Aventureros asturianos por el ancho del mundo. Asturias: Caja de Ahorros de Asturias, page 13-22, 2002. URL http: //www. nodulo. org/ec/2002/ n007p02.htm.

[51] Luis Camnitzer. La enseñanza del arte como fraude. http://es.scribd.com/doc/107083351/La-ensenanza-delarte-como-fraude. URL http://es.scribd.com/doc/107083351/ La-ensenanza-del - arte-como-fraude.

[52] Luis Camnitzer. El arte, la política y el mal ojo. Dominación cultural y alternativas ante la colonización, IV Bienal de La Habana, Cuba, 1991.

[53] Luis Camnitzer. La definición restringida del arte. Art Nexus, (13): 54-59, 1994 .

[54] LUIS. CAMNITZER. 200o. Pag. 15 y 16, Codificar y decodificar (1971).

[55] Luis Camnitzer. Didáctica de la liberación: arte conceptualista latinoamericano. CENDEAC, Murcia, 2009. 
[56] Luis Camnitzer. Una genealogía del arte conceptual latinoamericano. Continente Sul-Sur, (no.6, p.187), Noviembre 1997.

[57] García Cancini. Néstor: Diferentes, desiguales y desconectados. Mapas de la interculturalidad. Gedisa, Barcelona, 2004.

[58] Jonathan Crary. Suspensiones de la percepción. Madrid, Akal/Estudios Visuales, 2008.

[59] Regis Debray. Introduccion a La Mediologia. Editorial Paidós, Barcelona, 2001. ISBN 8449310261.

[6o] G. Deleuze. Lógica del sentido: Prólogo de Miguel Morey. Editorial Paidós, Barcelona, 2005. ISBN 9788449318030.

[61] Gilles Deleuze. ¿qué es el acto de creación? Fundación FEMIS. Paris, 1987.

[62] Gilles Deleuze. Foucault. Ediciones Paidós Ibérica, Barcelona, 1987. ISBN 978-84-7509-424-3.

[63] Gilles Deleuze. Conversaciones. Editorial Pre-Textos, Valencia, 1994. ISBN 978-84-8191-021-6.

[64] Gilles Deleuze. Lógica del sentido. Ediciones Paidós Ibérica, Barcelona, 2005. ISBN 978-84-493-1803-0.

[65] Gilles Deleuze and Félix Guattari. Rizoma: (introducción). Editorial Pre-Textos, Valencia, 1977. ISBN 978-84-85081-02-8.

[66] Gilles Deleuze and Félix Guattari. Mil mesetas: capitalismo y esquizofrenia. Editorial Pre-Textos, Valencia, 1994. ISBN 978-8485081-95-0.

[67] Jacques Derrida. La Escritura y la Diferencia. Anthropos Editorial, Barcelona, 1989. ISBN 9788476581261.

[68] Jacques Derrida. Artes de lo visible (1979-2004). Ellago Ediciones, Castellón, 2013. ISBN 978-84-92965-29-8. 
[69] Marcel Duchamp. Escritos: Duchamp du Signe. Editorial Gustavo Gili, Barcelona, 1975.

[7o] Arthur Efland. Una historia de la educación del arte: tendencias intelectuales y sociales en la enseñanza de las artes visuales. Ediciones Paidós Ibérica, Barcelona, 1990. ISBN 978-84-493-1237-3.

[71] Arthur Efland. Arte y cognición: la integración de las artes visuales en el curriculum. Ediciones Octaedro, Barcelona, 2004. ISBN 978-848063-639-1.

[72] Arthur Efland, Kerry Freedman, and Patricia Stuhr. La educación en el arte posmoderno. Ediciones Paidós Ibérica, Barcelona, 2003. ISBN 978-84-493-1422-3.

[73] Hacía

el Diálogo Metodológico and Graham Murdock. DIMENSIONES DE ANÁLISIS DE LA INVESTIGACIÓN EN COMUNICACIÓN. URL http://tinyurl. com/qhk3zzq.

[74] Marco Espinoza, Raúl MirandaMarco Espinoza, and Raúl Miranda. Mutaciones escénicas: mediamorfosis, transmedialidad y postproducción en el teatro chileno contemporáneo. RIL Editores, 2009. ISBN 9789562846868 .

[75] Safaa Fathy. D'ailleurs, derrida, 2008.

[76] Antonio Mendoza Fillola and Pedro C. Cerrillo. Intertextos: Aspectos Sobre la Recepción Del Discurso Artístico. Univ de Castilla La Mancha, 2003. ISBN 9788484272830.

[77] Michel Foucault. El sujeto y el poder. Revista mexicana de sociología, pages 3-20, 1988.

[78] Michel Foucault. Las palabras y las cosas: una arqueología de las ciencias humanas. Siglo XXI, Madrid, 1993.

[79] Michel Foucault. La arqueología del saber. Siglo XXI, Madrid, 1997. 
[8o] Michel Foucault. La hermeneutica del sujeto/The Hermeneutics of the Subject: Cursos Del College De France, 1981-1982/Lectures at the College De France, 1981-1982. Ediciones AKAL, Madrid, 2005.

[81] Pierre Francastel. Sociologia del arte. Alianza Editorial, 1998. URL http://dialnet.unirioja.es/servlet/openurl?url ver=Z39.88-2004\&rft_val_fmt=info: ofi/fmt: kev : mtx: book\& rft : isbn=8420615684.

[82] Néstor García Canclini. Culturas híbridas: estrategias para entrar y salir de la modernidad. 2001.

[83] Yves Michaud-Joseph Kosuth Juan Luis Martín Prada José Luis Brea Juan Luis Moraza Gérard Wajcman, Charles Harrison. Seminario arte y saber, 2003.

[84] Boris Groys. Bajo sospecha: una fenomenología de los medios. Editorial Pre-Textos, Valencia, 2008.

[85] Félix Guattari. Pour une refondation des pratiques sociales.

[86] Félix Guattari. Las tres ecologías. Editorial Pre-Textos, Valencia, 1990. ISBN 978-84-87101-29-8.

[87] Fernando Hernández y Hernández. Educación y cultura visual. Ediciones Octaedro, Barcelona, 2010. ISBN 978-84-9921-063-6.

[88] Brian Holme. autonomie artistique et société de conmmunication. (http://utangente.free.fr/anewpages/autoart.html).

[89] Martin Jay. Ojos abatidos: la denigración de la visión en el pensamiento francés. Madrid, Akal/Estudios Visuales, 2007. ISBN 978-84-4602555-9.

[9o] JLG. Film socialisme. Vega Film, Office Fédéral de la Culture, Télévision Suisse-Romande, Ville de Genève, La Suissimage, Fondation Vaudoise, Fonds Regio Films, Wild Bunch, Canal+, 2010. 
[91] Kirby Dick / Amy Ziering Kofman. Derrida, 2002.

[92] Karel Kosik. El individuo y la historia. Almagesto Buenos Aires, 1991. URL http://www. correntroig.org/IMG/pdf/Karel_Kosik_ -_El_individuo_y_la_historia.pdf.

[93] R KOSTELANETZ. Conversando con cage: ««pedagogia». Arte: proyectos e ideas, (o), 1992.

[94] Rosalind Krauss. Pasajes de escultura moderna. Editorial Akal, Madrid. ISBN 978-84-460-1141-5.

[95] Rosalind Krauss. La originalidad de la vanguardia y otros mitos modernos. Alianza Editorial, Madrid, 1996. ISBN 978-84-206-71352.

[96] Donal Kuspit. El fin del arte. www.akal.com, akal edition, 2006.

[97] Donald Kuspit. El artista suficientemente bueno: más allá del artista de vanguardia". Creación. Instituto de Estética y Teoría de las Artes, Madrid., (No. 5):pp., 36-46., Mayo, 1992.

[98] Lucy R. Lippard. Seis años: la desmaterializacion del objeto artístico. De 1966 a 1972. Ediciones AKAL, Madrid, 2004. ISBN 8446011751.

[99] M. MALÉVICH. La luz y el color. Arte: proyectos e ideas, (3), 1993.

[10o] Alberto Mañero. Actas Congreso Inars: la investigación en las artes plásticas y visuales : [noviembre de 1998, Centro Andaluz Contemporáneo, Isla de la Cartuja, Sevilla]. Universidad de Sevilla, 2003. ISBN 9788447207626.

[101] José Marina. Teoría de la inteligencia creadora. Editorial Anagrama, Barcelona. ISBN 978-84-339-1375-3.

[102] Martin Heidegger Martin Heidegger. Heidegger en castellano el origen de la obra de arte. http://www.heideggeriana.com.ar/textos/origen_obra_arte.htm. URL http://www.heideggeriana.com.ar/textos/origen_obra_ 
arte.htm. Vresión española de Helena Cortés y Arturo Leyte en: HEIDEGGER, MARTIN, Caminos del bosque, Madrid, Alianza, 1996. Sitio creado y actualizado por Horacio Potel.

[103] Danilo Martuccelli and José Federico Delos. Gramáticas del individuo. Editorial Losada, 2007.

[104] T. McEVILLEY. Exposiciones-reales e imaginarias en las imágenes y las palabras: arte y literatura. 1991.

[105] Thomas McEvilley. De la ruptura al cul de sac. Ediciones AKAL, Madrid, 2007. ISBN 9788446020905.

[106] Michel Melot. Breve historia de la imagen. Siruela, Madrid, 2010. ISBN 978-84-9841-345-8.

[107] Y MICHAUD. Una escuela bastante buena. Arte: proyectos e ideas, (3), 1993.

[108] Nicholas Mirzoeff. Una introducción a la cultura visual. Ediciones Paidós Ibérica, Barcelona, 2003. ISBN 9788449313905.

[109] W. J. T. Mitchell. Teoría de la imagen. Madrid, Akal/Estudios Visuales, 2009. ISBN 9788446025719.

[110] Juan Moraza. Ornamento y ley: procesos de contemporización y normatividad en arte contemporáneo. E.P.R. Murcia Cultural, S.A, February 2007. ISBN 978-84-935369-5-4.

[111] Moraza, Juan Luis, Brea, José Luis, and Martín Prada, Juan. UNIA arteypensamiento - (a-s) arte y saber. http://tinyurl.com/ozerdgx. URL http://tinyurl . com/o2erdgx.

[112] Edgar Morin. El método. Ediciones Cátedra, Madrid, 1997.

[113] Edgar Morin. Introducción al pensamiento complejo. Editorial Gedisa, Barcelona, 1998. ISBN 978-84-7432-518-8.

[114] Edgar Morin. Educar en la era planetaria. Editorial Gedisa, Barcelona, 2003. ISBN 978-84-7432-835-6. 
[115] Edgar Morin. Los siete saberes necesarios para la educación del futuro. Ediciones Paidós Ibérica, Barcelona, 2011.

[116] Edgar Morin. La mente bien ordenada. Editorial Seix Barral, Barcelona, 2012. ISBN 9788432209161.

[117] Frederic Munné. Entre el individuo y la sociedad. Barcelona, PPU, 1989.

[118] Susana Murillo. El discurso de Foucault: Estado, locura y anormalidad en la construcción del individuo moderno. Carrera de Sociología, Facultad de Ciencias Sociales, Oficina de Publicaciones del Ciclo Básico Común, Universidad de Buenos Aires, 1997.

[119] Santiago Ortiz Herrera, Juan Moraza, and Liwayway Alonso Mendoza. El inventor de historias ; Formas de límite. Diputación Provincial de Málaga. Centro de Ediciones de la Diputación de Málaga, February 2007. ISBN 978-84-7785-770-9.

[120] G PAPINI. La revolución universitaria. Arte: proyectos e ideas, (1), 1993.

[121] M PASTOR. Muntadas: Arqueología del silencio. Arte: proyectos e ideas, (1).

[122] J-F PIRSON. El espacio del otro. Arte: proyectos e ideas, (3), 1993.

[123] Jacques Rancière. El reparto de lo sensible: estética y política. CENTRO ARTE SALAMANCA, 2002. ISBN 9789560000675.

[124] Jacques Rancière. Sobre políticas estéticas. Museo de Arte Contemporáneo de Barcelona = Museu d'Art Contemporani de Barcelona Universidad Autónoma de Barcelona. Servicio de Publicaciones = Universitat Autònoma de Barcelona. Servei de Publicacions, September 2005. ISBN 978-84-89771-12-3.

[125] Jacques Rancière. El destino de las imágenes. POLITOPIAS, Pontevedra, 2010. 
[126] Jacques Rancière. El espectador emancipado. Ellago Ediciones, Castellón, 2010. ISBN 978-84-96720-92-3.

[127] Jacques Rancière. Las distancias del cine. Ellago Ediciones, Castellón, 2012. ISBN 978-84-92965-24-3.

[128] Jacques Rancière. Arte del movimiento y movimiento del arte. estética, política y performance. 23/03/2011.

[129] Cé Rendueles and Ana Useros Martín. Walter Benjamin: atlas/constelaciones. Círculo de Bellas Artes, Madrid, 2010. ISBN 978-84-87619-81-6.

[130] L. E. Shiner. La invención del arte: Una historia cultural. Ediciones Paidós Ibérica, Barcelona, 2004. ISBN 9788449316401.

[131] Kaja Silverman. El umbral del mundo visible. Madrid, Akal/Estudios Visuales, 2009. ISBN 9788446027706.

[132] R SMITHSON. Entropía y los nuevos monumentos, en Robert Smithson. El paisaje entrópic. IVAM, Valencia, 1993.

[133] Raoul Vaneigem. Tratado del saber vivir para uso de las jóvenes generaciones. Anagrama, Barcelona, 1998. ISBN 9788433900937.

[134] Jorge Wagensberg. Ideas Sobre La Complejidad Del Mundo. Tusquets Editores, Barcelona, 2003. ISBN 9788483108598.

[135] Jorge Wagensberg. La rebelión de las formas: o cómo perseverar cuando la incertidumbre aprieta. Tusquets Editores, Barcelona, 2004. ISBN 9788483109755 .

[136] Jorge Wagensberg. A más cómo, menos por qué: 747 reflexiones con la intención de comprender lo fundamental, lo natural y lo cultural. Círculo de Lectores, 2006. ISBN 9788467220940.

[137] Jorge Wagensberg. El Gozo Intelectual: Teoría y Práctica Sobre la Inteligibilidad y la Belleza. Tusquets Editores, Barcelona, 2007. ISBN 9788483103951 . 
[138] Jorge Wagensberg. Si la naturaleza es la respuesta, ¿cuál era la pregunta?: y otros quinientos pensamientos sobre la incertidumbre. Tusquets Editores, Barcelona, 2008. ISBN 9788483830666.

[139] John Albert Walker and Sarah Chaplin. Una Introducción a la Cultura Visual. Octaedro, 2002. ISBN 9788480635424.

[140] Brian Wallis. Arte después de la modernidad. Ediciones AKAL, Madrid, 2001. ISBN 9788446011774.

[141] Aby Warburg. Atlas Mnemosyne. Ediciones AKAL, Madrid, 2010. ISBN 9788446028253.

[142] Antonio Weinrichter. La forma que piensa: tentativas en torno al cineensayo. Gobierno de Navarra, 2007. ISBN 9788423529377.

[143] Janet Wolff. La Produccion Social Del Arte. Ediciones AKAL, Madrid, 1998. ISBN 9788470903465.

[144] Mieke Bal y Miguel Á. Hernández-Navarro. 2Move Video Art Migration. CENDEAC, Murcia, 2008. 

MIERI EÑI ATAE ENÑA ALERAE. 